\title{
RESOLVING INSURANCE ISSUES FOR MULTI-UNIT BUILDINGS: LESSONS LEARNT FROM THE CANTERBURY AND THE KAIKŌURA EARTHQUAKES
}

By Emanuela (Emma) Gabor

A thesis submitted to the Victoria University of Wellington in fulfilment of the requirements for the degree of Doctor of Philosophy

25 February 2022 


\section{ABSTRACT}

This thesis set out to investigate why it was difficult to resolve insurance claims for multiunit buildings during the Canterbury (2010-2011) and the Kaikōura (2016) earthquakes. It found that the way multi-unit buildings are built gives rise to repair and decision dependencies. That means that sometimes units are not able to be repaired in isolation of each other; and where repair dependencies are triggered, owners need to make common decisions on how the property is reinstated. The problem is that not all types of multi-unit buildings have the infrastructure to recognise the repair dependencies or the governance structure to facilitate common decision-making. This leads to civil disputes between owners, which in turn create difficulties with progressing insurance claims, and even prevent repair of the properties.

While the thesis is concerned with insurance and finding better ways to resolve insurance claims for multi-unit buildings, the evidence is that this cannot be achieved without changes to the area of property law. Therefore, the thesis makes major recommendations in relation to how multi-units are built, managed, and regulated. The guiding principle is that multiunit buildings are communities, and they must be recognised as such. In addition, the thesis suggests changes to the way insurance companies manage claims for multi-unit buildings.

At the heart of the study is a broad empirical research into the Canterbury and the Kaikōura earthquakes. This includes extensive interviews, online surveys, and discussions with representatives of the insurance industry, government departments, lawyers, and homeowners. 


\section{ACKNOWLEDGMENTS}

I want to acknowledge those who have supported me in completing this project.

To God, a place of refuge in hard times.

To my mum, my forever supporter.

To my husband and children who allowed me to do this. I love you.

To my supervisors, Professor Graeme Austin and Dr Bevan Marten for their insight, wisdom, and gracious guidance. I am deeply grateful for your support at every stage of this project, and for your positive words of encouragement. Thank you for the practical advice, for cheering me on, and for believing in the importance of this research.

To Professor Tony Angelo QC for helping me with the entry into the PhD programme, and for always having an open door. Thank you for making academic life sweeter by exchanging jams with me.

To Dr Marcin Betkier, with whom I shared an office before he became famous. Like a big brother, you were always there to help.

To Dr Matteo Solinas, the Faculty of Law PhD Coordinator, for walking among us and introducing us to homemade Italian torta.

To Madeleine Collinge for her professionalism in proofreading the thesis.

To my fellow PhD students, for your friendship and camaraderie. I have enjoyed our shared dinners and our coffees at The Old Bailey. 


\section{Contents}

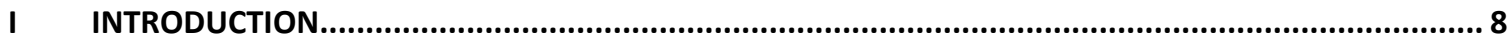

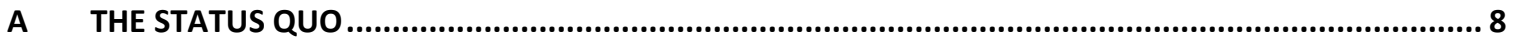

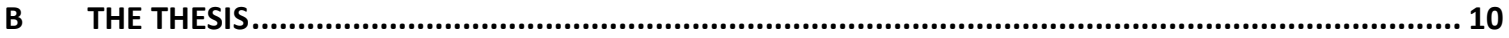

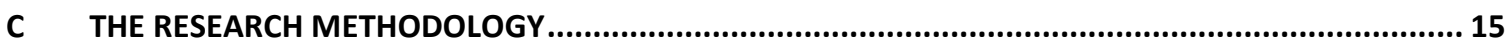

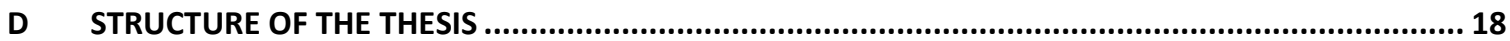

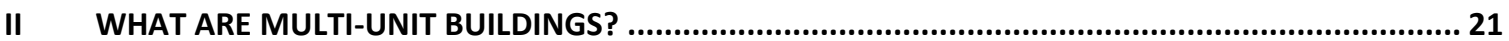

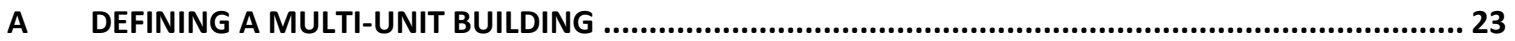

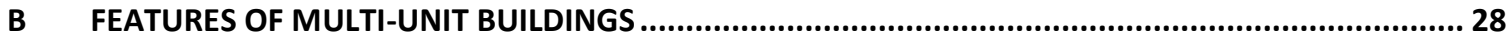

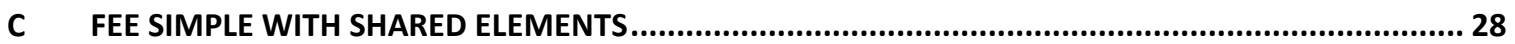

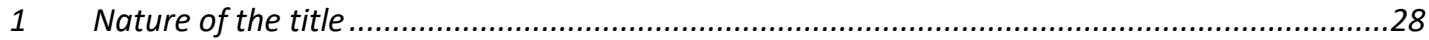

$2 \quad$ Fee simple properties with shared construction elements ................................................29

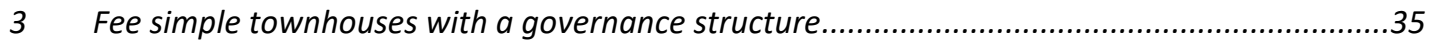

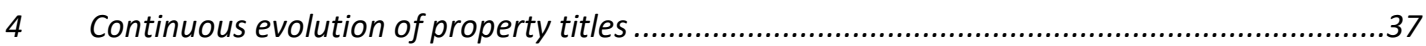

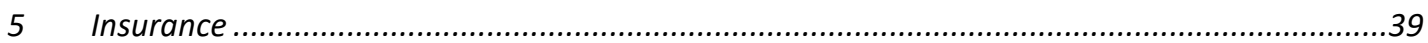

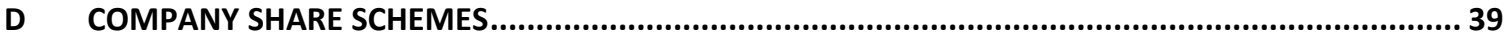

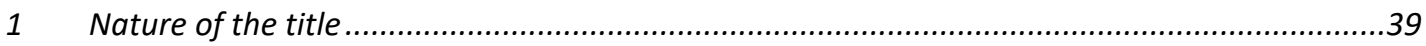

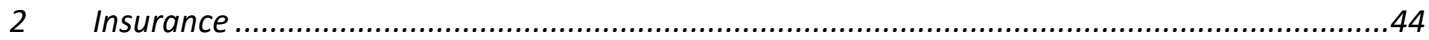

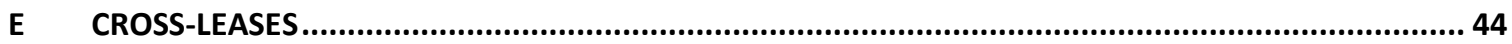

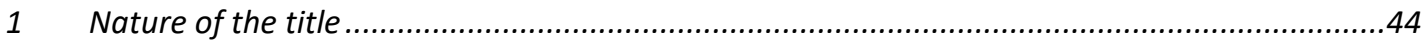

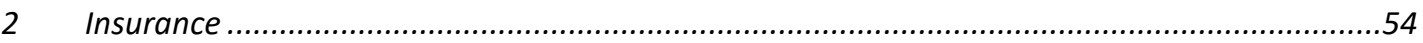

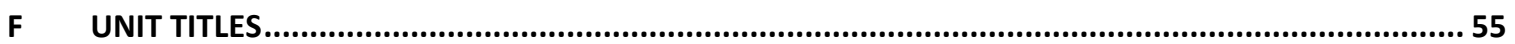

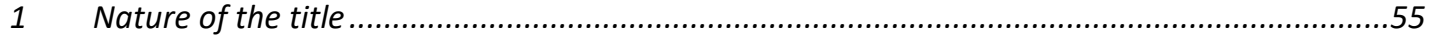

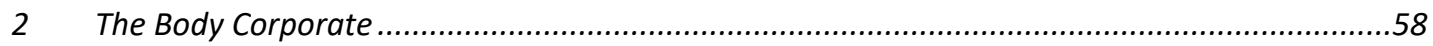

3 Unit owners' rights and responsibilities....................................................................60

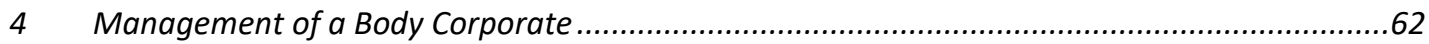

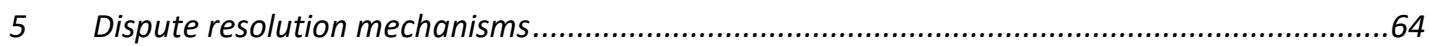

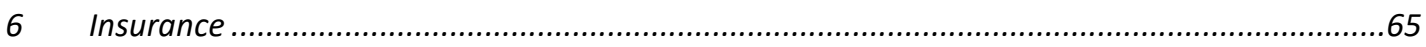

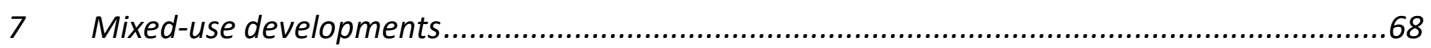

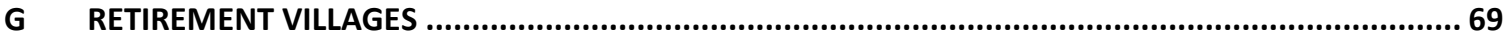

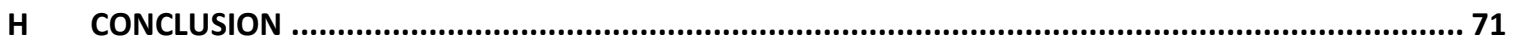

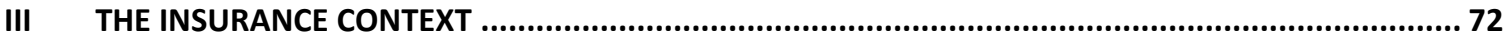

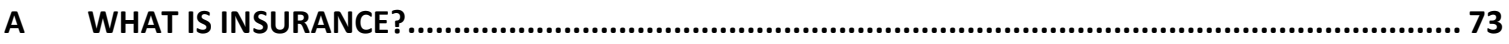

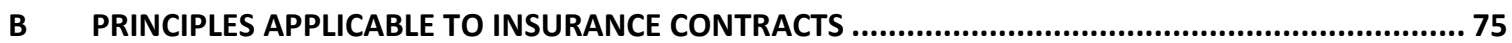




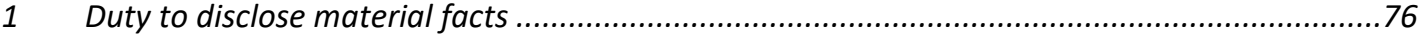

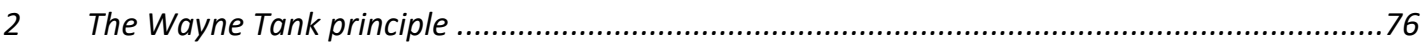

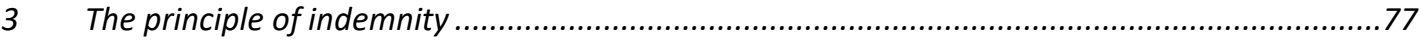

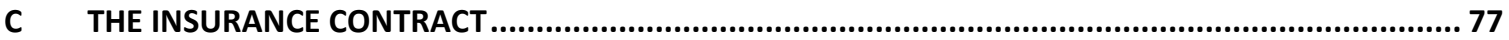

D THE BASICS OF A RESIDENTIAL HOME POLICY ............................................................ 80

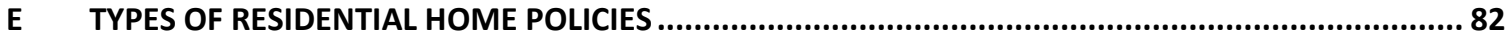

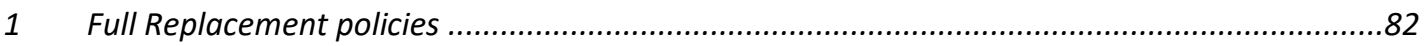

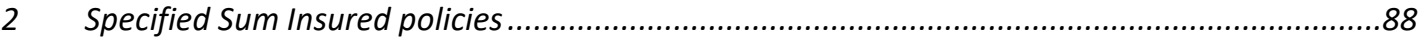

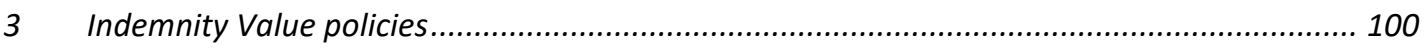

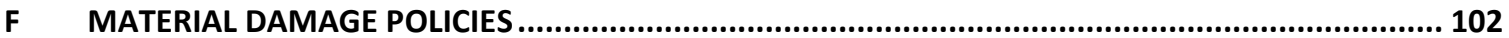

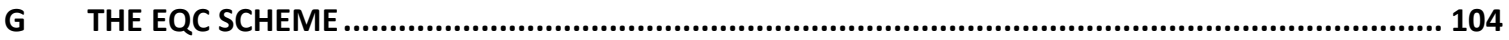

H INSURANCE COVER FOR NATURAL DISASTER DAMAGE ...................................................... 109

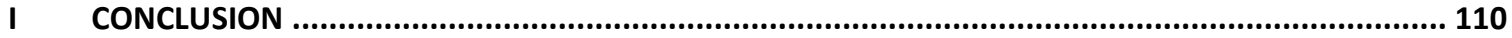

IV DIFFICULTIES IN RESOLVING MULTI-UNIT BUILDING CLAIMS: THE CANTERBURY AND THE

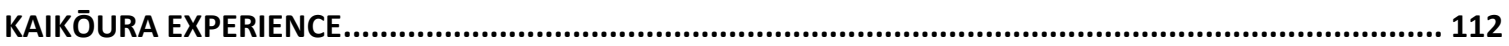

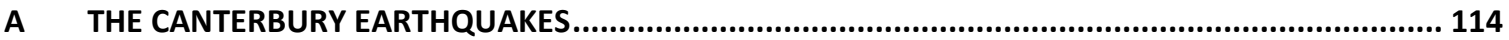

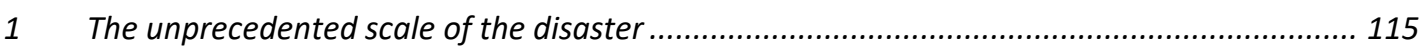

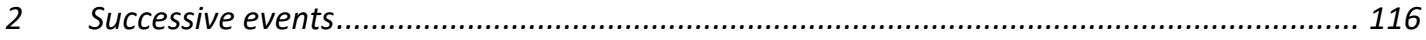

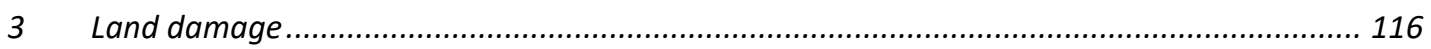

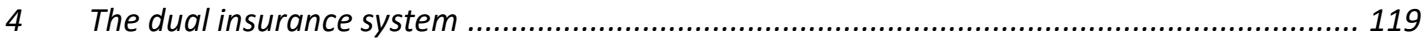

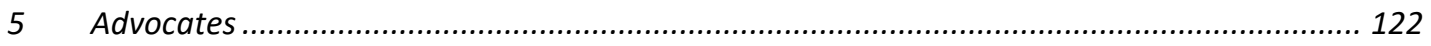

6 Disputes related to interpretation of insurance policies.............................................. 124

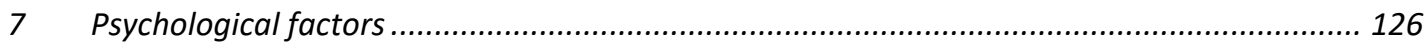

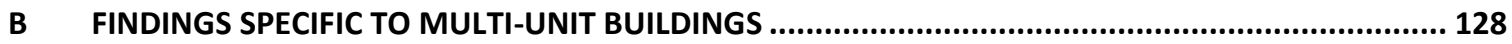

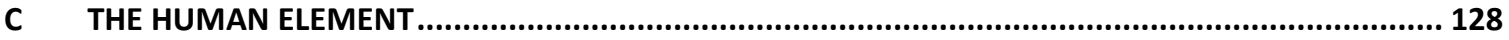

1 Lack of understanding of ownership structure ............................................................. 129

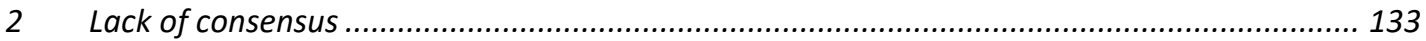

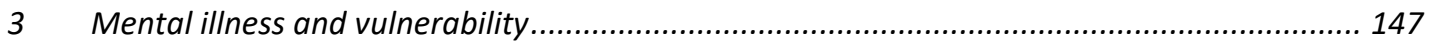

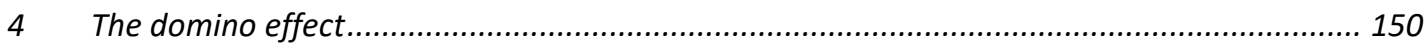

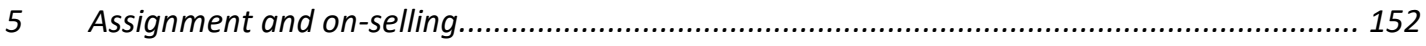

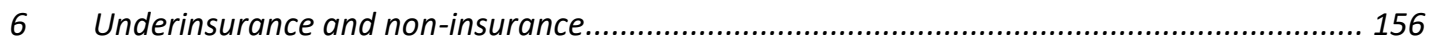

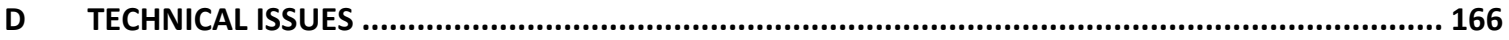

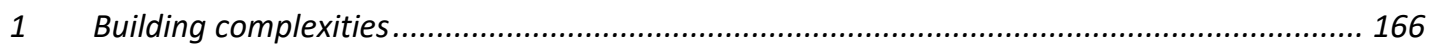

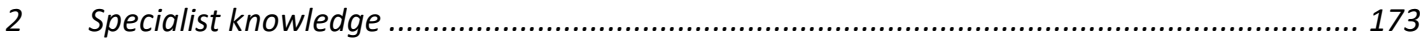

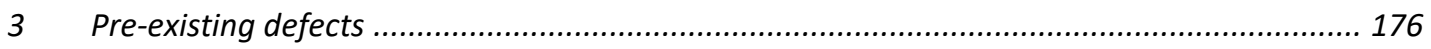

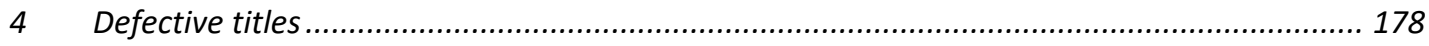




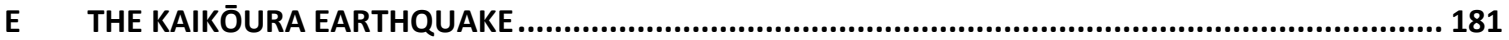

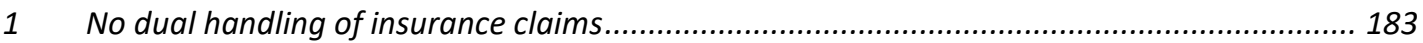

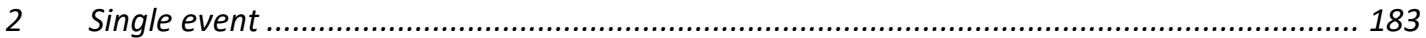

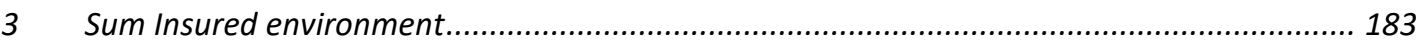

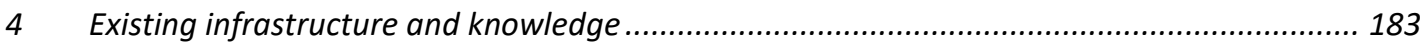

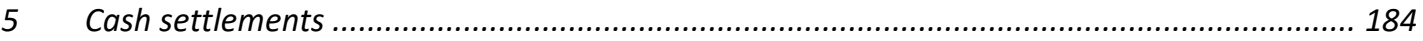

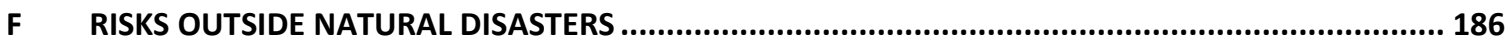

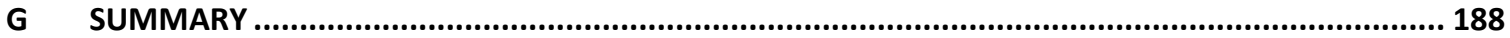

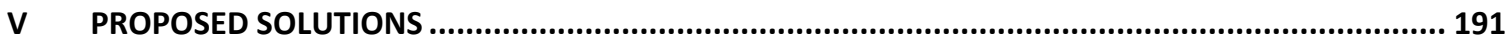

A PROPERTY LAW MEASURES

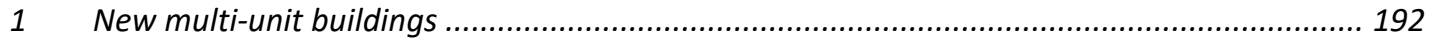

2 Existing housing stock: The guiding principle in finding the solutions.................................... 200

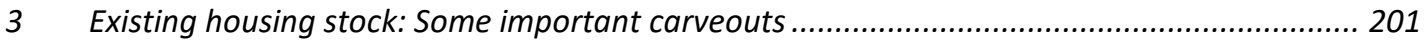

$4 \quad$ Existing housing stock: Three property law reforms................................................................ 205

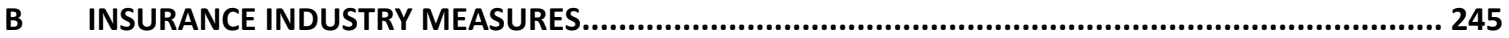

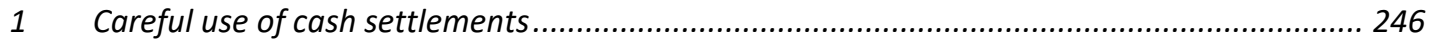

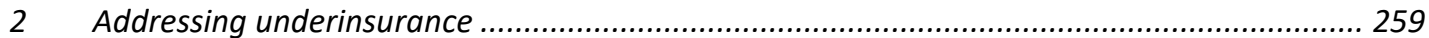

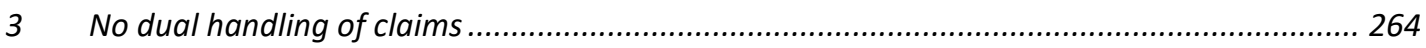

$4 \quad$ Better data collection on policies for multi-unit buildings ........................................................ 269

$5 \quad$ Prioritising claims for cross-lease properties and fee simple townhouses .............................. 271

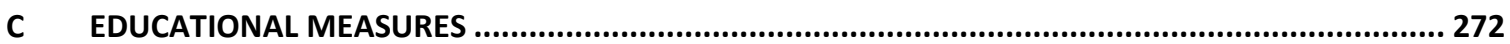

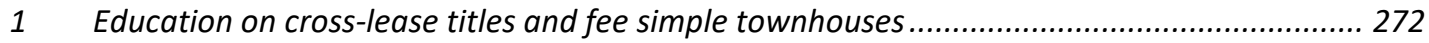

2 Education on assignment of insurance claims and on-selling .............................................. 273

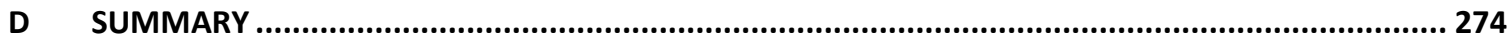

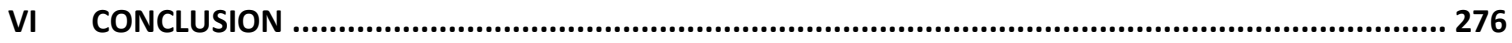

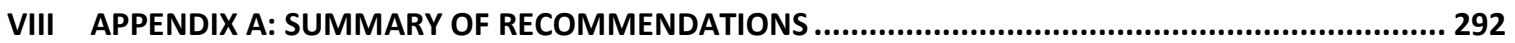

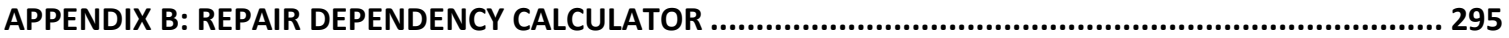

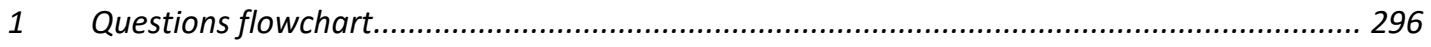

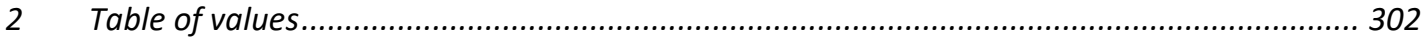

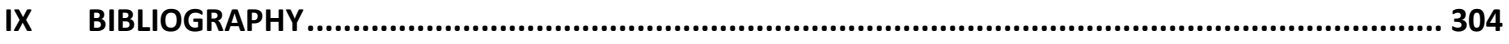

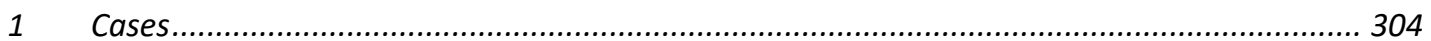

$2 \quad$ Legislation, Regulations, Bills, and Codes of Practice ............................................................. 309

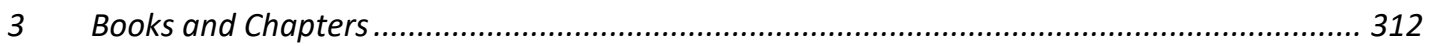

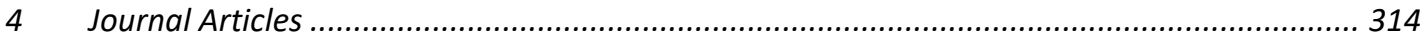

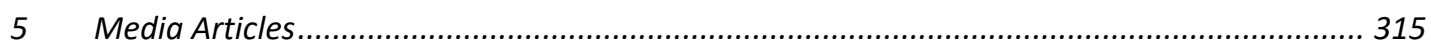




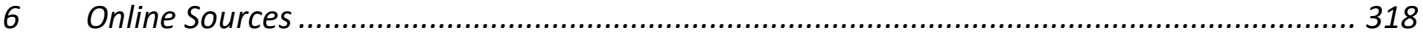

$7 \quad$ Documents Released under the Official Information Act 1982 ............................................. 323

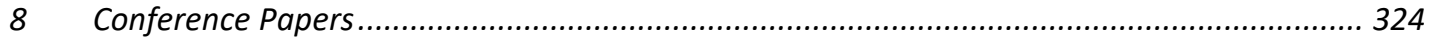

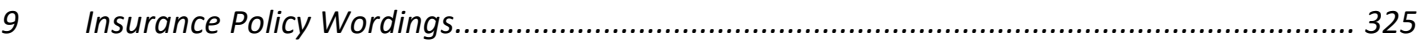

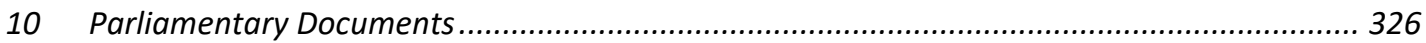

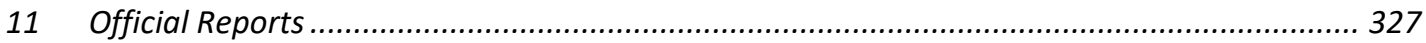

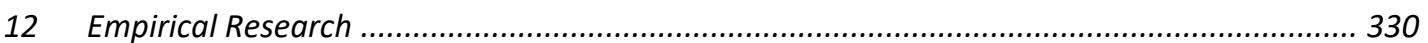

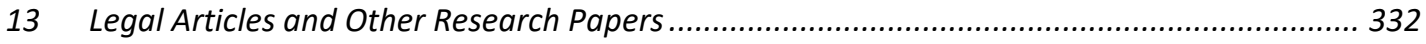

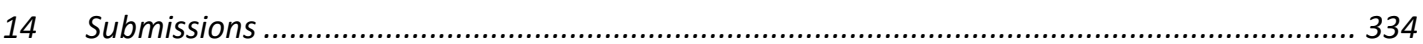




\section{INTRODUCTION}

\section{A The Status Quo}

There are over 215,000 cross-lease properties ${ }^{1}$ and 143,000 unit titles ${ }^{2}$ in New Zealand. They represent about 20 per cent of the country's housing stock. ${ }^{3}$ In addition, there are an uncounted number of fee simple townhouses and company share schemes that also provide multi-unit living. The number of multi-unit buildings is growing rapidly, supported by national and local government policies promoting higher density living, and everincreasing activity from property developers responding to rising demand for more affordable housing. ${ }^{4}$ Statistics New Zealand confirmed that the number of building consents for multi-unit buildings grew 22 per cent to September 2019 and that they outpaced those for standalone houses. ${ }^{5}$

Over the last 60 years, New Zealand has had at least four major developments in the evolution of property titles that cater for multi-unit living. The first was the emergence of company share schemes in the 1950s-1960s. Around the same time, in the early 1960s, cross-lease titles appeared, then in 1972, unit titles; and, in the last few years, fee simple townhouses developed to accommodate high-density living.

\footnotetext{
${ }^{1}$ Craig Fredrickson Arrested (Re)development? A Study of Cross Lease and Unit Titles in Auckland (Auckland Council technical report TR2017/025, 10 October 2017) <www. knowledgeauckland.org.nz/publications/arrested-re-development-a-study-of-cross-lease-and-unit-titles-inauckland>; Joanna Pidgeon "Property - Converting Cross Leases to Freehold and Unit Titles" (NZLS webinar, 2020).

${ }^{2}$ Fredrickson, above $\mathrm{n} 1$.

${ }^{3}$ Fredrickson, above $\mathrm{n} 1$.

${ }^{4}$ Wellington City Council "Providing home for Wellingtonians" <www.wellington.govt.nz>; Hunter Calder "Local Focus: Hamilton high-rise houses on the rise" The New Zealand Herald (online ed, 21 January 2019); BRANZ "What is medium-density housing?" (October 2017) <www.branz.co.nz>; MBIE Review of the Unit Titles Act 2010 (online ed, December 2016) discussion document found on Glaister Ennor's website <www.glaister.co.nz>.

${ }^{5}$ Statistics New Zealand High density housing on the rise (online ed, 31 October 2019) <www.stats.govt.nz>.
} 
One important aspect is that property titles often developed ad-hoc by lawyers under instructions from property developers rather than through a careful legislative process.

So, for the last 60 years there has been a largely unguided metamorphosis of the property titles landscape and an increase in the number of multi-unit buildings.

In addition, the level of building complexities has increased. It is now more than two homeowners sharing a driveway, and houses that are built near each other, often sharing construction elements such as party walls, common roofs, and common foundations. Some fee simple properties are now built strata style, on top of each other, similar to unit titles. ${ }^{6}$

However, multi-unit buildings present problems when it comes to repairs. The Canterbury earthquakes that struck the city of Christchurch and the surrounding Canterbury region between 2010 and 2011 threw multi-unit buildings into the spotlight. There was widespread damage to the housing stock, including damage to thousands of multi-unit buildings. ${ }^{7}$ Resolving insurance claims for multi-unit buildings proved difficult. The claims have been called nightmares ${ }^{8}$ and some have created irreconcilable situations that prevented reinstatement of damage. Some owners were not able to have their properties repaired. ${ }^{9}$

The difficult Canterbury experience coupled with an unprecedented increase in the number of multi-unit buildings using a fee simple structure led to insurance companies becoming concerned about the feasibility of insurance for multi-unit buildings. ${ }^{10}$ In January 2021, the

\footnotetext{
${ }^{6}$ Advertisement for a strata fee simple property at West Hills <www.https://westhills.co.nz/view-byprice\#price-0>. [Advertisement]

${ }^{7}$ EQC "Multi-Unit Buildings FAQs" (27 January 2021) <www.eqc.govt.nz>; Jeremy Finn and Elizabeth Toomey (eds) Legal Response to Natural Disasters (Thomson Reuters, Wellington, 2015) at 323.

${ }^{8}$ Duncan Webb "Multi-unit dwellings the big insurance nightmare" Stuff (online ed, 16 September 2013).

${ }_{9}^{9}$ Interview with Residential Advisory Services, Government Department (Emma Gabor, Christchurch, 28 May 2019) [Interview with RAS]; Focus Group discussion (Emma Gabor, Wellington, 14 September 2017); Interview with Residential Risk Analysis Ltd, Consultancy Company (Emma Gabor, Wellington, 20 April 2018); Jamie Small “Christchurch family's rebuild botched, can't sell land tied in cross lease" Stuff (online ed, 19 October 2017).

10 Interview with Chair of the ICNZ Personal Lines Committee (Emma Gabor, via Zoom Wellington/Auckland, 15 February 2021); IAG New Zealand "Supplementary Submission to the Finance and Expenditure Committee on the Unit Titles (Strengthening Body Corporate Governance and Other Matters) Amendment Bill 2021 (25 June 2021).
} 
Insurance Council of New Zealand (ICNZ) issued a public announcement cautioning home buyers that some insurers are no longer going to offer insurance on an individual basis to multi-unit buildings that do not have a Body Corporate structure. ${ }^{11}$ It appears that insurance companies sought government intervention to alleviate the difficulties encountered in managing claims for multi-unit buildings, but so far with little success. ${ }^{12}$ This prompted insurance companies to issue a warning to the public about the complexities surrounding multi-unit buildings. Unavailability of insurance has a downstream effect on availability of mortgage finance, ${ }^{13}$ and ultimately on asset protection.

\section{B The Thesis}

The thesis set out to investigate why it was difficult to resolve insurance claims for multiunit buildings in Canterbury and in Kaikōura, and what can be done to improve the insurance claims process.

It finds that the way multi-unit buildings are built gives rise to repair and decision dependencies. Sometimes it is not possible to repair a unit without affecting the neighbouring unit or units. Where there is damage to shared elements, owners need to work together to find solutions. This is more straightforward for unit titles and company share schemes that are insured under one insurance policy, have a governance structure, and a pre-determined way of making decisions through voting. But cross-lease properties and fee simple townhouses do not generally have a governance structure and there is no predetermined way of making decisions about the shared elements. Sometimes, owners have

\footnotetext{
${ }^{11}$ ICNZ "Insurers caution home buyers to be wary of insurance pitfalls for multi-unit buildings" Scoop Business (press release, 27 January 2021) <https://www.icnz.org.nz/media-resources/mediareleases/single/item/insurers-caution-home-buyers-to-be-wary-of-insurance-pitfalls-for-multi-unitbuildings/>. [ICNZ "Caution"]

${ }^{12}$ Interview with Chair of the ICNZ Personal Lines Committee.

${ }^{13}$ As banks require insurance when lending under a mortgage, and Schedule 2 of the PLA 2007 implies a covenant to insure in all mortgage contracts.
} 
a veto power that makes it difficult to achieve consensus. Owners often insure their units on an individual basis, which increases the number of decision makers. Banks also have a say in what happens to the insurance proceeds, which adds another layer of decision dependency.

The uncertainty of the legal obligations, and the difficulty in enforcing the legal rights, leads to civil disputes. Civil disputes that arise during an insurance claim affect the prompt resolution of the claim. These problems became apparent during the Canterbury earthquakes, but they existed before the earthquakes and continued to exist after the earthquakes. The Kaikōura earthquake (2016) provided some examples of how insurers could improve the insurance claim process, but the improved methods do not completely address the problem.

The thesis recommends a major intervention in property ownership in New Zealand. This is necessary in order to avoid civil disputes that can delay resolving insurance claims. A lot of money is tied into housing. Often a home is a person's most valuable asset. Therefore, it is important to ensure prompt reinstatement of a property following a loss.

The thesis adds to the existing body of knowledge in three ways. The first is by refining our understanding of what a multi-unit building is. This new understanding then underpins the rest of the thesis. The second is by examining the experience of the Canterbury and the Kaikōura earthquakes. This involves adding insight into the problems, drawing conclusions, and proposing solutions. Finally, the thesis identifies some inherent problems with multi-unit buildings that not only affect the resolution of insurance claims but have the ability to disrupt the good management of multi-unit buildings in their day-to-day operation.

\section{Refining our understanding of multi-unit buildings}

The thesis argues that multi-unit buildings are different to standalone houses and sit in a category of their own. They need specific rules for their good functioning. As such, it is important to find a principled way to define multi-unit buildings. 
The thesis posits that what makes a building a multi-unit building is not the legal category or title we give it, but rather the existence of two elements: a repair dependency and a decision dependency. To that end, even fee simple titles, titles that have not been traditionally associated with the term multi-unit buildings, can be multi-unit buildings if they have repair dependencies.

When properties are built with shared construction elements, this gives rise to repair dependencies. In turn, the repair dependencies give rise to decision dependencies. The thesis introduces and defines these two terms.

Dependencies are not of equal value but run on a spectrum. The thesis develops a new tool, a repair dependency calculator, to determine a property's repair dependency score. The thesis decides that a score of 50 means a significant repair dependency. The designation of significant repair dependency is important, and it drives different proposals for resolution.

The calculator is a useful tool, but it is not crucial in understanding the thesis. The basis of the algorithm is that any property with common foundations will fall into the significant repair dependency category. It is the existence of the shared foundations that will create significant repair dependencies.

As for the decision dependencies, they can have multiple layers in a multi-unit community. The first layer is the owners themselves, who need to decide what to do with the property. Insurers also have a say in how the property is going to be reinstated. In addition, if there are multiple insurers on site, they also need to agree between themselves, creating a double decision dependency. ${ }^{14}$ And if the loss is caused by a natural disaster, this requires involvement from the statutory insurer, the Earthquake Commission (EQC), ${ }^{15}$ adding to the dependency layer. Finally, for cross-leases and fee simple titles, banks also have a say

\footnotetext{
${ }^{14}$ See discussion in Chapter III, part E.

${ }^{15}$ See discussion in Chapter III, part G.
} 
in directing the insurance payment, either toward paying the owners' debts or toward reinstating the property. ${ }^{16}$

\section{Explaining the Canterbury and the Kaikoura experience}

The thesis presents evidence that there were two categories of problems that affected insurance claims for multi-unit buildings, and divides them into human issues and technical issues.

The thesis explores the human issues to find that they encompassed a variety of situations that impeded common decision making. These included misunderstanding the obligations under the property title, lack of consensus, different agendas between owners, and owner vulnerabilities.

As for the technical issues, the most important was the realisation that where damage affected the common elements of a building, it was not possible to repair the units separate from each other. Insurers realised they needed a whole-of-building approach. That required owners and insurers to work together in coming up with a repair strategy.

The thesis contrasts the situation of Body Corporates, where there was only one insurance policy and one insurer, with the cross-leases and fee simple townhouses' experience where there were multiple policyholders, multiple insurers, multiple policies with different levels of cover, and multiple decision-makers.

The thesis discusses the insurers' struggle to liaise with multiple owners and with each other and how this led the insurers to create a sui-generis project to resolve insurance claims in a way that reduced the decision dependency.

The thesis also aims to enhance the understanding of the danger of underinsurance. It points to evidence that in Canterbury most Body Corporates were underinsured. ${ }^{17}$ The thesis

\footnotetext{
${ }^{16}$ See discussion in Chapter II, parts $\mathrm{C}$ and $\mathrm{E}$.

${ }^{17}$ Interview with IAG New Zealand, Insurance Company (Emma Gabor, Wellington, 21 November 2017); Interview with Young Hunter, Law Firm (Emma Gabor, Christchurch, 28 November 2017); Interview with
} 
explains why the Body Corporates experienced underinsurance while residential properties did not. ${ }^{18}$

A thorny issue, underinsurance is a major concern in the context of a multi-unit building as it has a domino effect on the other members of the multi-unit community.

The Kaikōura experience was different. The research found that claims were resolved much faster. There were two main reasons for that. The first was that insurers chose to resolve claims by cash settlement rather than become involved with the repairs. The thesis examines whether cash settlements are a suitable way of resolving insurance claims for multi-unit buildings. It concludes that while cash settlements might be an acceptable method of resolving claims, there need to be certain safeguards around them. The thesis proposes measures to protect homeowners when insurance companies want to settle claims via a cash payment.

The second reason insurance claims were resolved faster during the Kaikōura earthquake was that insurance companies had a chance to improve their claims processing methods. One such improvement, and probably the most significant, was removing the dual handling of claims with EQC. When the Kaikoura event happened, EQC and the private insurers agreed on an agency approach to resolving claims, whereby the private insurers would manage claims on behalf of EQC and themselves. The thesis examines the effect of this new approach.

\section{Identifying inherent problems with multi-unit buildings}

Finally, the thesis argues that while property titles have evolved, legislation lagged, and there has not been an in-depth assessment of the impact caused by the repair and the decision dependencies. There is a paucity of legislative infrastructure to support the management of multi-unit buildings.

Grant Shand Barristers and Solicitors; Richard Land and Janine Ballinger (Duncan Cotterill, a law firm) "Property Update 'The legalities of the property landscape' (online ed, 22 August 2013) $<w w w . d u n c a n c o t t e r i l l . c o m>$.

${ }^{18}$ See discussion in Chapter III, Part E2. 
Only unit titles are subject to dedicated legislation. ${ }^{19}$ In contrast, multi-unit buildings organised within cross-leases and fee simple titles have developed ad-hoc, driven by property developers' interests in finding ways around the legislative restrictions or concerned with maximising profit from the sale of the properties. Company share schemes have also developed ad-hoc, although they have been retrospectively provided for in various Acts, ${ }^{20}$ and more recently in the Land Transfer Act $2017 .{ }^{21}$

The thesis recommends changes that not only assist with insurance claims, but strengthen the day-to-day management of cross-leases and fee simple townhouses.

\section{The Research Methodology}

\section{Empirical research}

To understand what happened in Canterbury and Kaikōura, I spoke to those involved at the coalface of insurance claims. I sought feedback from insurance companies, loss adjusters, lawyers who acted for insurance companies, and from the ICNZ. I included government agencies such as EQC and the Residential Advisory Service (RAS).

RAS was established by the Government with the purpose of assisting homeowners who had difficulties in advancing their insurance claims in Canterbury. RAS assisted hundreds of multi-unit building owners. ${ }^{22}$ That meant RAS had the knowledge and therefore the authority to speak on many aspects of insurance claims.

An important source of information was Nine Dots, the agency tasked to set up the Shared Property Project. The Shared Property Project was the sui-generis initiative by EQC and the private insurers to resolve insurance claims for cross-lease properties. The project had

\footnotetext{
${ }^{19}$ Originally Unit Titles Act 1972, now Unit Titles Act 2010.

${ }^{20}$ Companies Amendment Act 1964; Companies (Amendment) Act (No 2) 1965; Income Tax Act 2007, s CD31.

${ }^{21}$ Land Transfer Act 2017, Part 3, subpart 6.

${ }^{22}$ Interview with RAS.
} 
over 1,200 cross-lease properties under its scope, so information from Nine Dots was invaluable.

The annual Insurance Law Conference in September 2017 created an opportunity for a focus group discussion. There was a small group of five people made up of a representative from EQC, an insurance company representative, a loss adjuster, a lawyer advising Body Corporates, and a lawyer advising insurance companies. Although a small number, the attendees had wide experience with multi-unit building claims, in particular the EQC representative who was leading EQC's response team for multi-unit buildings at the time. ${ }^{23}$

Another method of research was an online survey of insurance companies, loss adjusting companies, EQC, ICNZ, and lawyers.

From the start it was important to hear the homeowners' views and about their experience with the insurance claims. However, it was difficult to find an efficient way of contacting homeowners. The Shared Property Project had no centralised database that would have the email addresses of the cross-lease owners. ${ }^{24}$ As a result, they could not email owners with a link to a survey. And, in any event, it would have only received feedback from crosslease owners, which would not have been representative enough. In contrast, RAS had a database of owners of multi-unit buildings, and the database was a mixture of different multi-unit building owners, so it would have been perfect for the research. While initial discussions with RAS were promising, it was not possible for RAS to send bulk emails as the emails would have been considered spam. ${ }^{25}$ In the end, I found a small number of homeowners through word of mouth.

To counterbalance the lack of homeowner interviews, the research took the following measures. The most important and valuable was talking to RAS. As stated above, RAS aided hundreds of homeowners who had insurance claims for multi-unit buildings. RAS was able to share about the difficulties faced by homeowners. When selecting lawyers for

\footnotetext{
${ }^{23}$ Focus Group discussion.

${ }^{24}$ Interview with Nine Dots, Consultancy Company (Emma Gabor, Rotorua, 14 November 2017).

${ }^{25}$ Possibly concerned with the application of the Unsolicited Electronic Messages Act 2007.
} 
interviews, there was a deliberate decision to include lawyers who acted for homeowners. The study also included media reports of homeowners' stories.

In addition, the thesis made use and referred to interviews recorded in an independent research paper by Elizabeth Toomey, Jeremy Finn, Jacinta Ruru, and Ben FranceHudson. ${ }^{26}$ This was an academic paper examining multi-unit buildings from a property law perspective, which also used the Canterbury experience to highlight the deficiencies of multi-unit building ownership. I refer to this paper throughout the thesis as the Toomey Finn research paper.

Government departments were a good source of information. In the wake of the Canterbury earthquakes, the government sought advice on multi-unit buildings. The Official Information Act requests to Treasury, EQC, and the Department of Prime Minister and Cabinet (DPMC) inform the study.

It was a little more difficult to find information on the Kaikōura earthquake, with most interviewees focusing on the Canterbury earthquakes. Indeed, the Canterbury earthquakes dwarfed the Kaikoura event by sheer size and level of complexity. To overcome this, I approached one insurance company with a special questionnaire on the Kaikoura earthquake. This was useful in obtaining more information specific to the Kaikōura event.

\section{Academic literature}

I have not been able to locate academic literature on the issue of insurance for multi-unit buildings in New Zealand. The reduced bibliography reflects that.

However, there are scholarly papers examining multi-unit buildings from a property law perspective. The most relevant to the thesis is the Toomey Finn research paper released in June 2017. Although that research was aimed at identifying improvements to the existing land tenure models in New Zealand for multi-unit buildings, it referred extensively to the poor insurance claims experience to underscore the shortcomings of multi-unit buildings. The Toomey Finn research paper starts from the premise that there are deficiencies in the way multi-unit buildings function, and suggests changes to the ownership and use of multi-

\footnotetext{
${ }^{26}$ Elizabeth Toomey and others Revised Legal Frameworks for Ownership and Use of Multi-dwelling Units (BRANZ Report ER23, 6 June 2017). [Toomey Finn research paper]
} 
unit buildings. In contrast, I start from the premise that there were difficulties in resolving insurance claims for multi-unit buildings and conclude that there are deficiencies in the way multi-unit buildings work. There is a cross-over between the two studies. Indeed, the Toomey Finn research paper proves the point that insurance follows property rights. Where property rights are uncertain, this leads to disputes between owners which in turn impede resolution of insurance claims.

Another helpful resource was the book Legal Response to Natural Disasters. ${ }^{27}$ The book chronicled the difficulties experienced by lawyers in the aftermath of the Canterbury earthquakes and in particular the lack of information and guidance available. Relevant to the thesis are Chapters 10 and 14, which examine legal difficulties caused by insurance issues and some specific difficulties with unit titles and cross-lease properties.

\section{Case law}

Finally, the study draws knowledge from the numerous court decisions that followed the Canterbury earthquakes. There were so many litigated claims, that the High Court set up a special Christchurch Earthquake List. ${ }^{28}$ The study refers to landmark cases and lawsuits that relate to multi-unit buildings.

\section{Structure of the Thesis}

The thesis proceeds as follows.

Chapter II "What are multi-unit buildings?" accomplishes two tasks. First, it examines what makes a building a multi-unit building. It notes that currently there is no agreed definition. Different studies have used different terms and have included different property titles in their discussion. The thesis postulates that it is crucial to find a principled way of determining what makes a building a multi-unit building. To that end it proposes a new test

\footnotetext{
${ }^{27}$ Finn Legal Response to Natural Disasters, above n 7.

${ }^{28}$ Canterbury Earthquake List <www.courtsofnz.govt.nz/the-courts/high-court/high-court-lists/earthquakelist-christchurch/>.
} 
in defining a multi-unit building based on the repair and the decision dependencies. The remaining part of the second chapter introduces the various types of property titles that currently cater for multi-unit living. This is important because each title is slightly different, which affects the management of the community affairs, and of the insurance claims. This section prepares the ground for understanding the elements that create a multi-unit building community and the discussion in Chapters IV and V. The chapter also explains why it has not included and assessed retirement villages, and why retirement villages might not be true multi-unit buildings. The thesis takes a different approach to retirement villages than EQC and other scholars who studied multi-unit buildings.

Chapter III "The insurance context" describes the insurance landscape in New Zealand. It has three main purposes. The first is to provide understanding on how insurance works and what are the limitations of insurance cover. The second purpose of the chapter is to describe the insurance policies available for multi-unit buildings. The chapter highlights the difference between Full Replacement policies and Sum Insured policies. It explains that policies that have a monetary cap create an increased risk of underinsurance. The chapter investigates the issue of underinsurance. The third part of the chapter explains the EQC scheme and its role in dealing with natural disaster claims. It explains the relationship between the private insurers and the statutory insurer and what led to the dual handling of insurance claims.

Chapter IV "Difficulties in resolving multi-unit building claims" delves into the Canterbury and the Kaikōura insurance claims' experience. This chapter tells the human story of the earthquakes: the aggravations caused by the delay, the impact of dual handling of claims, the difficult neighbours, the cash settlements that never went on site, the technical arguments between insurers, the tears, the whims, the deadlocks. It depicts the reality of human emotions and personal interests as they come at odds with property rights and community interests, all forced through a long and frustrating insurance claim process.

Chapter V "Proposed solutions" distils the learnings from the Canterbury and the Kaikoura earthquakes and proposes solutions for the future. The thesis wrestles with the proposals as they go beyond the realm of insurance claims. The thesis finds it inevitable to propose changes to property law, changes that go to the heart of how multi-unit buildings are 
constructed and managed. The thesis proposes imposing a governance structure on crossleases and fee simple townhouses with significant repair dependencies, as well as compulsory common insurance. It makes recommendations on improving the legislative support for management of multi-unit communities. The thesis acknowledges that the proposals are intrusive. As such, this chapter discusses at length the reasons for the proposals, and the arguments in support. It notes that the proposals are not without boundaries and discusses these boundaries. The thesis also proposes changes to the insurance claims process, and some educational measures.

Chapter VI "Conclusion" summarises the findings of the research and adds insight and commentary on the problems and what can be done to resolve them. The "Summary of Recommendations" then lists the proposals in an easy-to-follow format. 


\section{WHAT ARE MULTI-UNIT BUILDINGS?}

Medium and high-density housing has been expanding rapidly in New Zealand and it is forecast to become more common in the future. Both central and local government want to encourage higher density living. ${ }^{29}$ In a report issued in October 2017 , BRANZ, ${ }^{30}$ which describes itself as an independent research organisation providing advice to the building industry and to the government, observed that two-to-four storey attached houses are growing in popularity with young professionals, smaller families, and those who no longer have children living at home. ${ }^{31}$ Given the country's shift to later family formation, smaller families, and an aged population, BRANZ expected these types of houses to become more widespread in the future. That opinion followed the one expressed by Hon Dr Nick Smith, then-Minister of Building and Construction who said: ${ }^{32}$

Townhouses and apartments have become a more significant and important part of the mix of housing options for New Zealanders, with the number and size of complexes growing rapidly. There are three drivers for this change. First, our cities are becoming larger and the value of land has increased due to increased demand. Second, people are looking for housing options that reduce commute times to the central city. Third, our household size is becoming smaller and more diverse with a larger proportion of people both retired and younger without children. The Government wants to support this change with improved legislation to support higher density living.

Economists, academics, architects, and planners support these developments. In an opinion article in 2019, the chief economist at PricewaterhouseCoopers called the existing single dwelling housing zone "sinister" and argued that it is "time to abolish all further use of the single dwelling zone". ${ }^{33}$ The Head of School and senior lecturer in urban design in the School of Architecture at Victoria University of Wellington thought that "infilling in

\footnotetext{
${ }^{29}$ Wellington City Council "Providing home for Wellingtonians" and Calder, above $\mathrm{n} 4$.

${ }^{30}$ BRANZ <www.co.nz>.

${ }^{31}$ BRANZ "What is medium-density housing?", above $\mathrm{n} 4$.

${ }^{32}$ MBIE Review of the Unit Titles Act 2010, above $\mathrm{n} 4$.

${ }^{33}$ Geoff Cooper "Embrace housing density, it will breathe life into New Zealand's cities" Stuff (online ed, 26 September 2019).
} 
existing areas more intensively makes economic and environmental sense" 34 and suggested better urban planning, while the Chair of the Architectural Designers New Zealand contended in an article in March 2020 that urban sprawl cannot continue and that "intensification can unlock much needed housing supply". 35

In 2017, BRANZ commissioned a series of reports into medium-density housing. ${ }^{36}$ It noted that compact growth continues to be a predominant urban growth management model and it was a welcome way to avoid sprawl and reduce demand on the urban infrastructure, while protecting valuable productive land. ${ }^{37}$

Statistics New Zealand confirmed that the number of consents for high-density homes grew 22 per cent in the September 2019 year, and that the growth outnumbered that of standalone houses, which grew 6.1 per cent. ${ }^{38}$ In the September 2019 year, 40 per cent of all homes consented were high-density or multi-unit homes. ${ }^{39}$

And the number grew even higher in 2020 with a record 10,063 townhouses, flats, and units consented in the August 2020 year - the first time the number of consents for multiunit buildings exceeded 10,000 since the series began in 1990s. ${ }^{40}$

In large cities, new developments can be seen everywhere, in existing suburbs or new subdivisions. Townhouses are built abutting each other or on top of each other. Large apartment complexes pepper the cities.

\footnotetext{
${ }^{34}$ Morten Gjerde "NZ needs a proactive plan for high-density housing" Newsroom (online ed, 14 June 2017).

${ }^{35}$ Julie-Ann Ross "High-density housing has its place" Stuff (online ed, 12 March 2020).

${ }^{36}$ BRANZ <www.branz.co.nz/mdh>.

${ }^{37}$ Kate Bryson and Natalie Allen Defining medium-density housing (BRANZ Study Report SR376, Judgeford, Porirua, September 2017) at 1.

${ }^{38}$ Statistics New Zealand High density housing on the rise, above $\mathrm{n} 5$.

${ }^{39}$ Statistics New Zealand High density housing on the rise, above $\mathrm{n} 5$.

${ }^{40}$ Statistics New Zealand More than 10,000 townhouses, flats, and units consented in the last year (online ed, 30 September 2020) <www.stats.govt.nz>.
} 


\section{A Defining a Multi-Unit Building}

However, multi-unit buildings are not the same as standalone homes. They need to be treated in a class of their own. They require special rules for good functioning. Therefore, it is important to find a principled way of determining what makes a building a multi-unit building.

At the moment, there are different ways to describe medium and high-density housing. There is no agreed definition.

Statistics New Zealand for example uses two terms, "high-density housing" and "multiunit homes", and these terms include "apartments, townhouses, flats and units, and retirement village units". ${ }^{41}$

Insurance companies distinguish between cross-lease properties, which they call "shared property", ${ }^{42}$ and Body Corporates (unit titles), which they call "multi-unit buildings". 43

The Law Commission uses the term "shared ownership" but acknowledges that the term is "not entirely precise". ${ }^{44}$ The Law Commission utilises the term to refer to various methods of proprietary and quasi-proprietary rights to defined parts of single allotment of land and the structures on it. It includes company shares schemes, cross-lease properties, unit titles, and jointly owned access ways (driveways that are co-owned). ${ }^{45}$

The Toomey Finn research paper uses the term "multi-dwelling units". ${ }^{46}$ The report examines five types of properties: cross-leases, unit titles, Papakāinga and Whānau

\footnotetext{
${ }^{41}$ Statistics New Zealand High density housing on the rise, above $\mathrm{n} 5$.

${ }^{42}$ Hence the name "Shared Property Project" as detailed later in the thesis.

${ }^{43}$ Interview with IAG New Zealand; Interview with Residential Risk Analysis.

${ }^{44}$ Law Commission Shared Ownership of Land (NZLC 59, 1999) <www.lawcom.govt.nz> at [1].

${ }^{45}$ Law Commission, above $\mathrm{n} 44$.

${ }^{46}$ Toomey Finn research paper, above n 26 at 10.
} 
Housing on Māori freehold land, mixed-use buildings, and retirement units. The study does not attempt to define what a multi-dwelling unit is but evaluates five types of title that the authors believe fit within the term.

The Building Code distinguishes between detached dwellings, multi-unit dwellings, and group dwellings. ${ }^{47} \mathrm{~A}$ multi-unit dwelling is defined as "a building or use which contains more than one separate household or family." It gives the examples of an attached dwelling, flat, or multi-unit apartment.

EQC uses the term "multi-unit building" or "MUB" and this includes various types of housing divided not just by type of construction but also by legal title: ${ }^{48}$

- a flat, terraced house or apartment on a cross-lease title connected to another flat (usually owned and insured separately) [...]

- a unit-title apartment, townhouse or flat owned and managed in accordance with the Unit Titles Act by a Body Corporate. [...]

- a property with more than one insured dwelling, for example a rural complex with more than one dwelling or a home with a "granny flat" attached. [...]

- a mixed-use building, such as an apartment or flat above a shop or other commercial premises. [...]

- part of a rest home or retirement village. [...]

- under other less common forms of ownership such as company shares, freehold dwellings sharing a party wall, and some leasehold properties with attached dwellings.

Interestingly, under EQC's definition, even granny flats are multi-unit buildings despite being owned by the same owner as the house they are attached to. Another unusual inclusion is rural complexes with more than one dwelling. It is not uncommon in New Zealand to have more than one dwelling on a farm, but usually these would be standalone and, in any case, owned by the same owner. EQC's definition seems to be driven more by

\footnotetext{
${ }^{47}$ Building Code, cl 2; Building Regulations 1992, Schedule 1.

${ }^{48}$ EQC “Multi-Unit Buildings” (12 July 2019)<www.eqc.govt.nz>.
} 
EQC's need to identity the separate "dwellings" for which they have an obligation to pay under the Earthquake Commission Act 1993 (EQC Act). ${ }^{49}$ EQC's liability applies per dwelling, so for EQC it is imperative to establish how many dwellings are on a site. "Dwelling" is defined as any self-contained premises which are, or a capable of being, or are intended to be a home or a holiday home. ${ }^{50}$ It seems from EQC's perspective that the term multi-unit building is extended to cover situations where there are simply multiple dwellings on a site.

Internal documents released under the Official Information Act 1982 (OIA) show that EQC refined the multi-unit building definition to account for the potential impact of repair between dwellings. In a presentation to insurance companies, EQC explained how it defines multi-unit buildings: 51

\section{How EQC defines Multi-Unit Buildings}

"Any Dwelling where the repair strategy of one Dwelling, may potentially impact the repair strategy of another Dwelling."

The recognition of two narrower categories of MUBs became:

Dwellings that are physically joined together (Construction); and

Dwellings that are insured together (Insurance).

This has been translated into four categories. [...]

Each category of MUB has been given a code.

MUB1: Semi-detached and terraced houses

MUB2: Apartment buildings

MUB3: Mixed-Use

MUB4: Rest Homes

It is unclear whether EQC's criteria is cumulative (that is, the properties need both the Construction and the Insurance element). If yes, then a lot of the cross-lease properties would fall outside the term because they are not insured together. If EQC's criteria is on

\footnotetext{
${ }^{49}$ See full discussion on the application of the EQC Act in Chapter III, Part G.

${ }^{50}$ EQC Act, s 2.

${ }^{51}$ Training materials for insurance companies (obtained under Official Information Act 1982 request to EQC).
} 
an either/or basis (which is more likely), it would leave out cross-lease properties that are standalone (no common construction and no common insurance), as well as unit titles that are standalone but are not insured together due to a dysfunctional Body Corporate.

The thesis postulates that a multi-unit building can be any type of title. Whether a building is a multi-unit building does not depend on the legal category it sits in, but rather on the existence of two elements: a repair dependency and a decision dependency.

A repair dependency exists where a unit cannot be repaired in isolation of the neighbouring unit or units.

A decision dependency exists where the owners need to make common decisions about how the property is going to be reinstated.

Most of the time, the two elements exist together. However, there are some multi-unit buildings that do not have a repair dependency, only a decision dependency. For example, standalone cross-leases and standalone unit titles have no repair dependencies but owners still need to consult with each other over the repairs. The decision dependency is created by the legal title. The thesis refers to these properties as title-driven multi-unit buildings.

Dependencies run on a spectrum. At one end of the spectrum, there is no dependency at all in the case of a standalone fee simple property with no common elements. Adding a shared driveway gives rise to a limited repair and decision dependency. With common walls, the dependency grows. Adding a common roof and a common slab foundation will increase the dependency to a significant level.

It is important to point out that dependencies are not always triggered. If the damage is minor, localised to one unit, and does not impinge on the rights or property of another, a homeowner might be able to carry out the repairs without the need to consult the others. For example, there could be cosmetic damage caused by an earthquake or a flood that only require replacing the internal linings on a wall. Such damage would not entail collaboration between owners, as the common elements of the building are not affected. 
The thesis is concerned with situations where there is a potential for the dependencies to be triggered.

It is also important to clarify the situations where one person or entity owns multiple dwellings. I argue that there is a distinction between an owner of a house with a granny flat, or a farm with multiple dwellings - where all the dwellings are on one title, from situations where a person owns a row of individually titled dwellings. Where there are multiple dwellings on one title, there is no decision dependency, because the decision always sits with the (one) owner. The situation is different where one person owns multiple dwellings that could be sold individually because, at some point, there might be a decision dependency. If at the time of damage, there is only one owner for all units, the decision dependency reduces to nil, because that owner does not need to consult with anyone else. However, the decision dependency subsists and can be triggered again if a unit is sold to someone else. Another situation that could, in theory, trigger the decision dependency in such a situation is where the owner insures the units individually with different insurers. If that happens, the insurers need to agree with each other on how to reinstate the units.

The thesis develops a repair dependency calculator to determine a property's repair dependency score. This is described in detail in Chapter V, with the algorithm set out in Appendix A. The scores range between 0 and 100 points, with 0 meaning no repair dependency and 100 being maximum repair dependency. A score of 50 means that the property has a significant repair dependency. This designation is important and drives different recommendations.

The calculator is not vital in understanding the thesis but it is helpful as a tool. The thesis posits that what creates significant repair dependencies are common foundations. The algorithm has been created to give any property with common foundations a score of 50 or above, which would place these properties in the significant repair dependency category.

The thesis uses the terms shared foundations and common foundations interchangeably. The terms mostly refer to situations where units are built with a common concrete slab foundation, but this does not exclude the possibility of a timber foundation structure interlinked with the foundation structure of another unit. And, just to clarify, the terms also 
include situations where units are built on top of each other in such a way that the units above rely for support on the foundations of the units below.

\section{B Features of Multi-Unit Buildings}

Multi-unit buildings can have different kinds of titles. The underlying property title affects how the repair and the decision dependency manifest in practice. To understand the discussion in Chapter $\mathrm{V}$, the remaining part of this chapter sets out the key features of the following property titles:

- Fee simple, including fee simple with common shared elements.

- Company share schemes.

- Cross-lease properties.

- Unit titles.

\section{Fee Simple with Shared Elements}

\section{Nature of the title}

The fee simple estate is "the largest estate recognised by the common law and is of practical unlimited duration." ${ }^{52}$ Fee simple titles, colloquially known as freehold, are desirable and valuable because they confer three categories of rights: possession (including the right to exclude all others from the land), use and enjoyment (the right to use the land and buildings unrestricted), and alienation (the right to dispose of the property at will). ${ }^{53}$

\footnotetext{
${ }^{52}$ Tom Bennion "Introduction" in Elizabeth Toomey and JF Burrows (eds) New Zealand Land Law (3rd ed, Thomson Reuters, eBook, ProQuest Ebook, 2017) at 13.

${ }^{53}$ Bennion, above $\mathrm{n} 52$ at 13.
} 
There is a presumption at common law that the fee simple owner is "the owner of everything up to the sky and down to the centre of the earth". ${ }^{54}$ This presumption is extremely valuable when it comes to insurance claims and reinstatement of properties because owners can build up or below the existing structure without encroaching on someone else's title. That makes it simpler when it comes to repairs. I return to this point in Chapters IV and V when I contrast the position of fee simple properties with cross-lease properties.

Fee simple owners are at liberty to do what they please with the property, subject only to the restrictions imposed by law, ${ }^{55}$ in particular the law of nuisance and negligence. ${ }^{56}$

Significantly, there is no general obligation to keep the property in good repair. If the property gradually deteriorates, the neighbours cannot force the fee simple owner to upgrade it (although an action in private nuisance might be possible in some cases). If the property suffers damage in an insured event, the owner can choose to leave the damage unrepaired (subject to other obligations they might have to a mortgagee for example). It is only if the state of the property creates a hazard that the fee simple owner has a duty "to do that which is reasonable in all the circumstances...to prevent or minimise the known risk of damage or injury". ${ }^{57}$ This becomes significant when fee simple townhouses share construction elements and rely on each other for support.

\section{Fee simple properties with shared construction elements}

Owners of fee simple properties can choose to share certain elements of their property with another property. For example, a fee simple owner might grant the benefit of a right of way

\footnotetext{
${ }^{54}$ Corbett v Hill (1870) LR 9 Eq 671 at 673 cited in Megarry Robert and others The Law of Real Property (8th ed, Sweet \& Maxwell, London, 2012) at 112. However, this presumption has been qualified over the years by various statues and court decisions.

${ }^{55}$ Including significant restrictions imposed by the Resource Management Act 1991.

${ }^{56}$ Megarry Robert and others The Law of Real Property (8th ed, Sweet \& Maxwell, London, 2012).

${ }^{57}$ Leakey $v$ National Trust for Places of Historic Interest or Natural Beauty [1980] QB 485 at 524. See also Abbahall Ltd v Smee [2003] 1 All ER 465.
} 
over their land to a neighbour. The right of way is noted on the title in the form of an easement. The easement instrument will set out the rights and obligations of each party in relation to the maintenance of the shared property, and will be binding on future owners. The Property Law Act 2007 (PLA 2007) and the Land Transfer Regulations 2018 imply terms for maintenance, cost sharing, and dispute resolution for rights of ways in case the easements are incomplete. ${ }^{58}$

But the right to share is not restricted to driveways. Sometimes fee simple properties share structural walls, roofing elements, or foundations with another property. The thesis uses the term fee simple townhouses to refer to properties that share construction elements that go beyond a common driveway.

A townhouse is sometimes defined as a "dwelling unit, generally having two or more floors and attached to other similar units via party walls" 59 or "one of a row of similar houses that are usually joined by a shared wall". 60

Fee simple townhouses seem to have developed in the last ten years or so. They were not widespread at the time of the Canterbury earthquakes - only two interviewees referred to fee simple townhouses in Christchurch. ${ }^{61}$

However, in the last few years, the number of fee simple townhouses has increased. A search on the real estate listings in Auckland, Wellington and Christchurch on 23 September 2020, shows 655 new fee simple townhouses for sale or that have just been built. ${ }^{62}$ This is just a snapshot of a day in a calendar year taken at random. More fee simple

\footnotetext{
${ }^{58}$ PLA 2007, ss 308-312 and Schedule 5; Land Transfer Regulations 2018, Schedule 5.

59 "Glossary of Real Estate Terms" <www.realestate.co.nz>.

${ }^{60}$ Cambridge Dictionary <www.dictionary.cambridge.org>.

${ }^{61}$ Residential Advisory Service and EQC.

62 The search was done on TradeMe on 23 September 2020. These were five townhouses at 1-6/ 200 Panama Road, Mount Wellington, Auckland, 40 townhouses at 30 Sandy Lane, Avondale, Auckland, 12 townhouses at 11 Voyager Drive, Gulf Harbour, Rodney, six townhouses at 100 Target Rd, Glenfield, Auckland, 62 townhouses at 24 Seafarer Crescent, Stanmore Bay, Auckland, six townhouses at 8 Webber Street, Westmere,
} 
townhouses are built every week. Just by way of illustration, there are currently two major developments in the greater Wellington region. One is Kenepuru Landing which proposes to build 700 new houses including a large number of fee simple townhouses; the second is Plimmerton Farm which plans to build 2,000 residential dwellings, including a variety of housing options from medium to high density to rural lifestyle. ${ }^{63}$

Anecdotal evidence suggests that property developers have abandoned unit titles in favour of fee simple titles when they are building townhouses. A newspaper article in November 2020 , citing a nationwide property developer, ${ }^{64}$ suggested that property developers have studied the market and found that, when it comes to infill housing, most owners prefer fee simple instead of unit titles; that fee simple townhouses sell at a higher price; and that they stay less time on the market. ${ }^{65}$ The article said that property developers "try to steer clear of unit titles where they can". 66 Another property developer pointed out that New Zealanders prefer to buy fee simple titles and that there is no reason why housing intensification cannot be achieved by using fee simple titles even for very small land sites of 40 sqm. $^{67}$

Property developers prefer to use the fee simple title even when they build buildings in close proximity of each other or with shared construction elements. That means the

Auckland, 16 townhouses at 20 Houkura Way, Sandringham, Auckland, 42 townhouses at Rush Creek Drive, Westgate, Auckland, 30 townhouses at 24 and 47 Kopuru Road, Whenuapai, Auckland, 61 townhouses at 188-208 Victoria St, Wellington, 84 townhouses at 31 Avon St, Island Bay, Wellington (The Mews at Erskine), 152 townhouses at 97 Taranaki St, Wellington (The Paddington), 76 townhouses or duplexes at The Reserve, Wallaceville Estate, Upper Hutt, 20 duplexes at Parkway Rise, Wainuiomata, Lower Hutt, six townhouses at 35 Percy St, Christchurch, 21 townhouses at 21 Purchas St, St Albans, Christchurch, five townhouses at 88 Poulson St, Christchurch, five townhouses at 407 Hereford St, Christchurch, six townhouses at 108 Edgeware Road, Christchurch <www.trademe.co.nz〉.

${ }^{63}$ Kenepuru Landing <www.kenepurulanding.co.nz>; Porirua City Council <www.poriruacity.govt.nz〉.

${ }^{64}$ Williams Corporation <www.williamscorporation.co.nz/completed-projects>.

65 Dileepa Fonseka "Review or tweak? Government confronts body corporate review" Stuff (online ed, 22 November 2020).

${ }^{66}$ Fonseka, above n 65.

67 Brady Nixon "Market receptive intensification - A compact solution for Auckland and Housing Affordability" (Greater Auckland, April 2013) <www.greaterauckland.org.nz/wpcontent/uploads/2013/06/Fee-Simple-Intensification-Report-Unitary-Plan-April-2013.pdf> at 25. 
developers have to find a way of grafting ownership rights for the shared elements onto a property title which at its core is based on absolute ownership and ability to exclude others.

To enable this sharing of construction elements, the developer or the owners need to write terms on the title usually by way of easements and covenants. ${ }^{68}$

As a matter of practice, certain rights are created by the grant of an easement (for example, rights for support of buildings and rights to air and light). Other rights, which the law has not recognised as being capable of being protected by easement, are created by covenant. These include rights to view, rights to privacy, and rights to the protection of a building from weather.

Interestingly, and different to rights of ways, there are no legislative provisions to imply rules for maintenance, cost sharing, or dispute resolution mechanisms for owners who share building elements. In the past, scholars suggested that we need legislation to make provision in case a lawyer omits something in the easements or in the covenants. ${ }^{69}$

However, there has been some legislative intervention to make it easier to create easements. In 2002, the position in New Zealand changed to allow the same person to be the owner of both the servient and the dominant tenement (in other words, to be both a grantor and a grantee). ${ }^{70}$ This facilitates preparations for subdivisions ${ }^{71}$ and enables property developers, for example, to set easements from the beginning.

Importantly, it is usually the property developer who decides which elements are going to be shared. That means the developer decides not just the level of the repair dependencies, but also the easements and covenants, in other words the legal matrix that governs the relationship between the future owners.

\footnotetext{
${ }^{68}$ David Brown "Easements, Profits and Covenants" in Elizabeth Toomey and JF Burrows (eds) New Zealand Land Law (3rd ed, Thomson Reuters, eBook, ProQuest Ebook, 2017) at 1054.

69 Thomas Gibbons and others "Easements and Covenants: Pushing the Boundaries" (NZLS seminar, 2008). The authors refer to the Land Transfer Regulations 2002, a precursor of the 2018 Regulations.

${ }^{70}$ Brown, above n 68 at 1058.

${ }^{71}$ Brown, above n 68 at 1058.
} 
Scholars noted that developers have a significant power in selecting the way the building is designed, constructed, and managed. ${ }^{72}$ And they also noted that the interests of the developers do not always align with the interests of the homeowners. ${ }^{73}$ Unsurprisingly, the developers' main aim is to maximise the number of units on one lot and to ensure the entire development sells at a profit, while property owners might be concerned with privacy issues, enforcement of their rights and good management of the properties.

Developers sometimes employ marketing strategies in making the properties more attractive to sell. For example, a number of fee simple townhouses are being advertised as having no governance structure such as a Body Corporate, and no maintenance fees. ${ }^{74}$ Some advertisements refer to the elimination of "ongoing extra costs;" no body corporate fees will "ensure [the] ultimate lifestyle living" "76 or that the purchaser's lifestyle would be "worry free". ${ }^{77}$ Others advertise the fee simple title as "too good to miss. No Body Corporate fees!"78

\footnotetext{
${ }^{72}$ Hazel Easthope and Bill Randolph "Principal-agent problems in multi-unit developments: The impact of developer actions on the on-going management of strata titled properties" (2016) Environment and Planning Journal 1829 at 1838 .

${ }^{73}$ Easthope, above n 72 at 1838.

74 TradeMe advertisements for Lot 1262 Meola Road, Pt Chevalier, Auckland <https://www.trademe.co.nz/a/property/residential/sale/auckland/auckland-city/point-

chevalier/listing/3193744849>; $\quad$ Edgewater Villas, Tauranga <www.trademe.co.nz/a/property/residential/sale/bay-of-plenty/tauranga/city-centre/listing/3170761379>.

75 TradeMe advertisement for Edgewater Villas, Tauranga
<www.trademe.co.nz/a/property/residential/sale/bay-of-plenty/tauranga/city-centre/listing/3170761379>.

76 TradeMe advertisement for 26e Hastings Road, Mairangi Bay, Auckland. <www.trademe.co.nz/a/property/residential/sale/auckland/north-shore-city/mairangibay/listing/3199113901>.

${ }^{77}$ TradeMe advertisement for 188 Victoria St, Wellington <www.trademe.co.nz/a/property/new-homes/newtownhouse-terraced/wellington/wellington/wellington-central/listing $/ 2764363655$ ?bof=fJl7 $\mathrm{cnbW}>$.

78 TradeMe advertisement for Lot 3, 55 Great South Road, Papakura, Auckland. <www.trademe.co.nz/a/property/residential/sale/auckland/papakura/papakura/listing/3178456887>.
} 
In Australia, most multi-unit buildings are developed under a strata title ${ }^{79}$ (similar to New Zealand's unit title), a system which requires long term maintenance plans. ${ }^{80}$ Some developers have used the strategy of setting the maintenance levies at a low level in an effort to make the units more attractive to sell but this has been criticised for creating problems for the owners long term. ${ }^{81}$ In New Zealand, property developers seem to dispose of maintenance fees altogether even when the units are part of a larger development.

But not everyone agrees with the idea of multi-unit buildings developed under a fee simple structure with no Body Corporate and no plans for maintenance. Insurers are concerned about the lack of provision for maintenance because the housing stock is likely to deteriorate. ${ }^{82}$

One planner expressed concerns about fee simple townhouses, saying that: ${ }^{83}$

It is bound to create long term issues for rights of access to maintain/repair elements of the building. It foolishly eradicates the need for any formal maintenance plan that would keep the buildings looking tidy in years to come, and creates an issue for ongoing maintenance of shared services in the long term, such as onsite stormwater detention tanks etc, which have a limited life span.

It is not just the lack of maintenance that is of concern to the insurers, but the lack of a governance structure as well. Following the Canterbury earthquakes, insurers have tried to encourage the establishment of Body Corporates for properties that share construction elements. In a statement in January 2021, ICNZ said that: ${ }^{84}$

\footnotetext{
${ }^{79}$ Easthope, above n 72 at 1830.

${ }^{80}$ Easthope, above n 72 at 1830 .

${ }^{81}$ Easthope, above $\mathrm{n} 72$ at 1838 .

${ }^{82}$ Interview with Chair of the ICNZ Personal Lines Committee.

83 Online survey conducted by Jeremy Finn, Ben France-Hudson and Elizabeth Toomey "Damage, Destruction, Distress: Shared Ownership Debacles” (2016) 22 CantaLR 57 at 63.

${ }^{84}$ ICNZ "Caution”, above n 11.
} 
While body corporates can be seen as adding extra cost and administration for owners, they also offer a single point of insurance for the entire building, including units, shared spaces and common property. Critically this ensures all owners have insurance in place, with one insurer, meaning claims can be handled simply and efficiently.

In June 2021, in their supplementary submission on the Unit Titles (Strengthening Body Corporate Governance and Other Matters) Amendment Bill 2021, New Zealand's largest domestic insurer warned that owners of properties with shared construction elements might struggle to find insurance for their properties: ${ }^{85}$

As noted in our submission on the Bill, given the issues where common or shared property in a multi-unit development is not insured under a single insurance contract, there is a risk that if substantial developments in future aren't body corporates, they will find it hard to insure, or be uninsurable, because of complex ownership structures and the potential consequences and complexities when there is a claim. We are therefore concerned to see that some larger and more complex properties are being marketed as it being an advantage that they don't have a body corporate, when this could present challenges when the new owners come to insure it.

I return to this point in Chapter $\mathrm{V}$ to discuss what can be done to avoid problems with insurance for fee simple properties with shared elements and which do not have a Body Corporate structure.

\section{Fee simple townhouses with a governance structure}

Some property developers acknowledge that fee simple townhouses "need some of the collective elements a unit title offers". ${ }^{86}$ But, instead of creating a Body Corporate structure using the mechanism provided in the UTA, they create their own legal structure because

${ }^{85}$ IAG New Zealand "Supplementary Submission", above n 10. IAG New Zealand's Supplementary Submission to the Finance and Expenditure Committee on the Unit Titles (Strengthening Body Corporate Governance and Other Matters) Amendment Bill, 25 June 2021. <www.parliament.nz/resource/enNZ/53SCFE_EVI_99361_FE1681/5f43581c5c3d046404ff4476045c85d03d5a0cfe>.

${ }^{86}$ Fonseka, above n 65. 
they do not want to "entangle" the customers in the unit title system. ${ }^{87}$ It appears property developers "try to avoid the perceived stigma of loss of control" specific to unit titles. ${ }^{88}$ But one scholar noted that this difference is "illusory". ${ }^{89}$ I agree. If the townhouses are built with repair dependencies, these will trigger decision dependencies regardless of whether the owners want that or not. Finding ways to avoid making decisions together, does not remove the underlying repair dependency and it will be futile when, following a loss or a maintenance requirement, the repair dependencies are engaged.

Sometimes property developers create a governance structure in the form of a compulsory incorporated society of residents. ${ }^{90}$ The society has a constitution which sets out management rules for the development. ${ }^{91}$ The rules empower the society to manage the common areas, impose levies, and regulate behaviour within the grounds of the property. However, the Auckland District Law Society (ADLS) warned that legislation governing incorporated societies is more suitable for clubs than groups of property owners, and this "may well lead to a ticking time bomb in terms of these complexes". 92

One final point to note here. It is not compulsory for property developers to create governance structures for new fee simple developments. And not every property developer does. ${ }^{93}$ Even if they do, there are no minimum standards as to what terms should be contained in the governing documents. The rights and obligations of the homeowners (the

\footnotetext{
${ }^{87}$ Fonseka, above n 65.

88 Joanna Pidgeon and Susan Tappenden "Unit Titles" in Elizabeth Toomey and JF, J F Burrows (eds) New Zealand Land Law (3rd ed, Thomson Reuters, eBook, ProQuest EbookWellington, 2017) at 1123.

${ }^{89}$ Pidgeon and Tappenden, above n 88 at 1124.

90 Kerry O'Donnell “The nature of easements, covenants, consent notices and encumbrances” in Easements and Covenants - Pushing the Boundaries (NZLS seminar, 2008) at 7; Fonseka, above n 65.

91 An example is Erskine Residents Society Incorporated, register number 2735872 <www.isregister.companiesoffice.govt.nz>; another example is Hobsonville Point development in Auckland, a development of about 2,000 housing units and whose constitution can be found on its website <https://www.hprs.co.nz/wp-content/uploads/2016/11/HPRS-Constitution-December-2016.pdf>.

92 ADLS "Submission to the Finance and Expenditure Committee on the Unit Titles (Strengthening Body Corporate Governance and Other Matters) Amendment Bill 2021" (25 June 2021) at [3].

93 For example, the Kenepuru Landing development in Porirua does not appear to have an incorporated society of owners despite the properties sharing structural construction elements.
} 
legal matrix I mentioned before), and what is set out in the regulating documents are at the discretion of the property developer. In my view, this is undesirable.

\section{Continuous evolution of property titles}

Fee simple titles are not static, they continue to evolve.

In England there has been a new type of title called a flying freehold. ${ }^{94}$ This is similar to a strata title in that the properties are situated on top of each other, but the units are freehold, and the owners above do not own the fee simple in the land at ground level. I have noted something similar in New Zealand: strata properties advertised as freehold or fee simple. ${ }^{95}$ I approached the property developer for more information. The agent advertising the properties provided a pamphlet usually given to prospective purchasers. ${ }^{96}$

The pamphlet described the property as being a Fee Simple in Strata Title (FSST). ${ }^{97}$ I was not able to locate any literature on this type of title, but the brochure described the FSST title as being a "conventional fee simple subdivision" which introduces a new dimension of height. This requires a 3-D plan (not the usual 2-D plan) to identify the exact location for each dwelling. The title comes with both restrictive covenants (Code of Conduct) and positive land covenants that prescribe rules about insurance, maintenance, and dispute resolution. There are also easements for services, structural support, and others.

In relation to insurance, the document specifies that the owners will have to work together to select the insurance policy, and that the premium is divided based on the percentage of the replacement value of each owner's share. If one owner refuses to pay the premium, the covenants specify remedies. The document clarifies that there is no Body Corporate

\footnotetext{
${ }^{94}$ Judith-Anne Mackenzie Land Law (16th ed, Oxford University Press, Oxford, 2016) at 623.

${ }^{95}$ See Advertisement, above n 6.

96 "Information Sheet Pertaining to Fee Simple in Strata Titles" provided via email by Universal Homes (Property Developer) to Emma Gabor regarding strata fee simple property at West Hills, Auckland (7 April 2021). [Information on FSST titles]

${ }^{97}$ See Advertisement, above n 6.
} 
structure. It is unclear from the document whether decisions require a majority or unanimity.

The document acknowledges that subdivisions involving FSST titles are more complex than fee simple titles in terms of easements and the interrelationships between the parties. But it says that the advantage is that FSST titles allow property developers to "reduce the gross floor of area of dwellings to improve affordability without utilising a unit title structure". ${ }^{98}$

What happens with flying freehold or FSST titles is that the owner of the unit above relies on the owner of the unit below for support. Likewise, the owner of the unit below relies on the owner of the unit above to keep the roof in good repair to ensure the weathertightness of the building. The difficulty of course is that there are no intrinsic obligations that come with a fee simple title. In order to force a fee simple owner to keep the property in good repair there need to be positive covenants noted on the title to this effect. The quality of the legal documents setting out these obligations is really important.

FSST titles create significant repair dependencies. What is good though is that it appears that some property developers are aware of the dependencies (or "interrelationships" as they call them) and are creating the infrastructure to manage those dependencies. I have not seen a copy of an FSST title that has all the covenants, and I am therefore unable to draw any final conclusions on whether these titles have all the required covenants in place. But they are certainly very complex titles imposed on buildings with significant repair dependencies.

\footnotetext{
${ }^{98}$ Information on FSST titles, above n 96.
} 


\section{Insurance}

Fee simple owners can choose whether or not to insure the property, subject only to any contractual obligations a homeowner might agree to, such as a mortgage or a positive covenant.

If there is a mortgage, the bank is registered as an interested party on the policy. ${ }^{99}$ In that capacity, banks can direct what happens to the insurance money. ${ }^{100}$ This is noted on the insurance policy as well. For example, it might use a clause like this: ${ }^{101}$

\section{Having interested parties}

If you have a party who has a financial interest in property covered by this policy, such as a bank or finance company, we may partially or fully settle a claim by making payment to them. This payment will either go towards meeting or completely fulfilling our obligations under this policy.

The research has revealed some problems with banks requiring the payment to be paid toward the mortgage rather than the repair. I discuss these in detail in Chapters IV and V, along with the other findings related to fee simple townhouses in Canterbury.

\section{Company Share Schemes}

\section{Nature of the title}

While fee simple townhouses seem to be latest advancement in the history of multi-unit buildings, company share schemes are touted as the first type of "unit" development. ${ }^{102}$

\footnotetext{
${ }^{99}$ Interview with bank representative in Toomey Finn research paper, above n 26 at 78.

${ }^{100}$ PLA 2007, Schedule 2, cl 3(1).

101 AA Insurance Home insurance policy wording version AAI_HHOME_V2_1608 <www.aainsurance.co.nz/documents/policy-documents/home-insurance-policy.pdf>

${ }^{102}$ Law Commission, above at $\mathrm{n} 44$ at [1].
} 
They appeared in the late 1950s-early 1960s and were recognised by the Companies Amendment Act 1964. ${ }^{103}$

The arrangement is like a unit title in that the building is comprised of units: sometimes strata style, sometimes townhouse style. Despite the apparent likeness, a company share scheme is different to unit titles. A company holds the title to the land and to the building. The company then sells shares that entitle the purchaser to occupy one of the units. The purchaser does not acquire a property title, only shares in the company and a licence to occupy. All "owners" are shareholders in the company.

Company share properties are known under different names: flat-owning companies, ${ }^{104}$ company leases, ${ }^{105}$ or “own-your-own” flats. ${ }^{106}$ The Income Tax Act $2007^{107}$ defines a flatowning company as a company whose constitution provides that every registered shareholder is entitled to the use of a specific residential property in New Zealand owned by the company; and whose only significant assets are residential properties available for use by specific shareholders and funds reserved for meeting the company's costs.

The management of company shares schemes are largely matters of private contract dealt with according to their constitution. However, following their creation in the 1950s-1960s, they became subject to some legislative intervention. For example, the Companies Amendment Act 1964 permitted the registration of the licences under the Land Transfer Act $1952 .{ }^{108}$ In 1965, the Companies (Amendment) Act (No 2) stated that the grant of a licence to occupy was not a return on capital. ${ }^{109}$ Currently, subpart 6 of the Land Transfer

\footnotetext{
${ }^{103}$ Law Commission, above at $\mathrm{n} 44$ at [1].

${ }^{104}$ Income Tax Act 2007, s CD31.

105 Resource Management Act 1991, s 2.

106 William Lavelle (architect) "Submission to the Statutes Revision Committee on the Office and Flat Ownership Bill 1972" (15 February 1972) located in Archive New Zealand file titled "36 Parliament Statutes Revision Committee - Bills - Public Bills - Unit Titles [Session 3]”, Archive ref ABGX W3706 16127 Box 29.

107 Section CD31.

${ }^{108}$ Law Commission, above at $\mathrm{n} 44$ at [2].

${ }^{109}$ Law Commission, above at n 44 at [2].
} 
Act 2017 makes provision for the issue, registration, mortgage, surrender, and cancellation of licences for flat-owning companies. ${ }^{110}$ The Income Tax Act 2007 provides a way for a company share scheme to avoid being taxed on any financial surplus reported in the administration of the company property. ${ }^{111}$ While company share schemes have been set up by private arrangements, over time, the government adopted legislation to facilitate their functioning.

\section{How company share schemes work}

The title is formed around a company that holds the ownership of land and building(s). The company has a name used as an identifier for the development. ${ }^{112}$ The scheme is managed by a Board of Directors, who must be owners in the building. The company has a constitution that sets out the rules of management. ${ }^{113}$ The company imposes levies for the maintenance of the building and for insurance. ${ }^{114}$ All owners contribute to the upkeep of the building. The owners exercise their decisions through voting, and sometimes there are restrictions on what they can do. ${ }^{115}$ When someone buys a company share apartment, they must receive consent to do so by the directors. The directors often interview prospective purchasers $^{116}$ and can veto the transaction.

The Board of Directors exercise tight control over the management of the company. ${ }^{117}$ Most company share schemes prohibit renting out the units and insist on owner occupier

\footnotetext{
${ }^{110}$ Sections 122-137.

111 Section CD31(1).

112 For example, the Gateway Apartments in Wellington.

${ }^{113}$ Interview with Roger Phillips, Ex Board Member for Company Share Property (Emma Gabor, Wellington, 25 September 2018).

${ }^{114}$ Davy v Scarrott [2016] NZHC 1791, (2016) 17 NZCPR 523.

115 See for example Thomson v Dorchester Apartments [2015] NZHC 2476.

116 Claire Tyler (Rainey Collins, a law firm) “Company Share Apartments - What Are They and How Do They Work?” (9 November 2013) <www.raineycollins.co.nz>.

117 Gateway Flats Limited "Submission to the Statutes and Revisions Committee on the Flat and Office Ownership Bill 1972 (20 March 1972) in folder document title "36th Parliament - Statutes Revision Committee - Bills- Public Bills- Unit Titles [Session 3]" located with Archive New Zealand, archive reference ABGX W3706 16127 Box 29; Lavelle "Submission”, above n 106.
} 
requirements. ${ }^{118}$ In 1972, in a submission on the Flat and Office Ownership Bill, a group of directors of a company share scheme in Wellington explained that such restrictions were intentional and based on the belief that the "worthwhileness" of living in a residential block was dependent entirely upon the solidarity of the community spirit, the identity of interest and welfare among the occupiers, and the acceptance of the fact that every owner's interest was inseparable from the interests of the other owners. ${ }^{119}$ The directors believed that only owner occupiers could have the vested interest of looking after the properties and the affairs of the group. They were afraid that if units were held by absentee owners, the absent owners would not be concerned about the domestic affairs and living conditions of the occupants because their interest would be to obtain the "maximum return for a minimum of maintenance". ${ }^{120}$ Indeed, in Chapter IV, I discuss how in Canterbury absentee owners caused problems because of lack of engagement and being driven by different interests.

The community view expressed above is important, so I return to it. Members of a multiunit building community need to have a system through which they can exercise their rights, while also having their interests protected. Without rules for management and a voting system, it is difficult to exercise the decision dependency. Fortunately, company share schemes seem to have a strong governance system in place through the Board of Directors, as well as a mechanism for making decisions through voting.

In the early days of company share schemes, there was a fear that the directors might abuse the veto power in relation to new purchasers and this might impact on the banks' ability to enforce a security if they needed to. ${ }^{121}$ In 1971, the government introduced the Flats and Office Ownership Bill, which, among other things, proposed a forced conversion of

\footnotetext{
118 Gateway Flats Limited "Submission to the Statutes and Revisions Committee on the Flat and Office Ownership Bill 1972 (5 April 1972) in folder document title "36th Parliament - Statutes Revision Committee - Bills- Public Bills- Unit Titles [Session 3]" located with Archive New Zealand, archive reference ABGX W3706 16127 Box 29; Lavelle "Submission", above n 106.

${ }^{119}$ Gateway Flats "Submission” (20 March 1972), above n 117.

${ }^{120}$ Gateway Flats "Submission” (20 March 1972), above n 117.

${ }^{121}$ Gateway Flats "Submission” (20 March 1972), above n 117.
} 
company shares schemes to unit titles. The proposal attracted opposition from owners of company shares properties. ${ }^{122}$

In the end, the government removed company share schemes from the ambit of the Flat and Office Ownership Bill and the new Act passed under the name of the Unit Titles Act 1972 (UTA 1972). ${ }^{123}$ However, Part IV of the UTA 1972 made provisions for the voluntary conversion of company share schemes to unit titles.

In 1999, the Law Commission undertook a review of the company share schemes. ${ }^{124}$ The Law Commission recommended that no new schemes of this type be created, explaining that the reason for their existence has effectively ceased with the enactment of the UTA $1972 .{ }^{125}$ It is unclear whether there are still company share schemes being created today.

\section{Are company share schemes multi-unit buildings?}

It is possible to argue that, technically speaking, company share properties are not multiunit buildings because there is only one owner: the company. However, the company is simply a medium through which the true ownership of the property is presented. Behind the company façade, there are many owners with different interests, having property rights recognised at law. Seen in this light, company share schemes are just another type of multiunit building.

\footnotetext{
122 Gateway Flats “Submission” (20 March 1972), above n 117; Gateway Flats “Submission” (5 April 1972), above n 118; Lavelle "Submission", above n 106; Jeff Andrew (secretary to three company share schemes) "Personal submission to the Statutes and Revisions Committee on the Flat and Office Ownership Bill 1972" (17 February 1972) in folder document title "36th Parliament - Statutes Revision Committee - Bills- Public Bills- Unit Titles [Session 3]" located with Archive New Zealand, archive reference ABGX W3706 16127 Box 29.

${ }^{124}$ Law Commission, above at $\mathrm{n} 44$ at [14].

${ }^{125}$ Law Commission, above at n 44 at [3].
} 


\section{Insurance}

In terms of insurance, the company as the owner of the land and the building is responsible for insuring the building as a whole. ${ }^{126}$ The company is also responsible for maintenance. This is set out in the company constitution. ${ }^{127}$ I have not been able to determine whether the bank has a say in what happens to the insurance proceeds.

The Canterbury earthquakes have not revealed any specific issues with company share properties. Most interviewees were in fact unfamiliar with this type of property structure. It appears that there were not many company share schemes in Christchurch. Government papers released by the Department of Prime Minister and Cabinet under the OIA show that the Canterbury Earthquake Recovery Authority (CERA) received advice from a property law expert that there were very few company share schemes in the Greater Christchurch area. ${ }^{128}$ This might explain the absence of issues arising out of the Canterbury earthquakes. CERA appears not to have included company share schemes in their assessments or advice related to multi-unit buildings. ${ }^{129}$

\section{E Cross-Leases}

\section{$1 \quad$ Nature of the title}

\section{History}

Until the 1950s, the traditional method of property densification was by way of subdividing a larger fee simple section into smaller fee simple sections. But there were limitations on the size of the subdivided land, ranging from one third of an acre to one fifth of an acre depending on the relevant territorial authority. ${ }^{130}$ Then in 1950s, the first type of unit

\footnotetext{
${ }^{126}$ Interview with Roger Phillips.

127 Tyler, above n 116.

${ }^{128}$ Briefing to the Minister for Canterbury Earthquake Recovery "Shared Property: Reaching Agreement and Resolving Disputes" (5 June 2014) M13 - 14/622 at [18] (Obtained under Official Information Act 1982 Request to the Department of Prime Minister and Cabinet).

${ }^{129}$ Briefing to the Minister, above n 128.

${ }^{130}$ Pidgeon and Tappenden, above n 88 at 1216.
} 
development appeared, structured as a company share scheme, which I have discussed above. But company share schemes were not popular with banks because owners did not receive a property title, only a licence to occupy. ${ }^{131}$ That meant that it was difficult to buy a company share unit because finance was not readily available. The limitations imposed by the company share structure led property developers to find alternative ways of subdividing which eventually led to the creation of the cross-lease titles. ${ }^{132}$

This was assisted by two legislative changes. First, two Acts, the Municipal Corporations Act 1954 and the Land Subdivision in Counties Act 1946, were amended to say that a lease of any part of a building was not a subdivision of land. ${ }^{133}$ Second, local authorities began to allow more than one dwelling in one building. ${ }^{134}$ An Auckland lawyer with assistance from a retired land registrar came up with the idea of a new title, which became known as the cross-lease title. The creation was intended "to fill the enormous gap caused by the absence of any flat unit legislation" 135 and enabled homeowners to get title to a flat in a common building.

\section{Characteristics}

A cross-lease title is almost the opposite of a company share scheme. While in a company share scheme, one company holds the land and the buildings, in a cross-lease, all the owners own the land together in undivided shares. ${ }^{136}$ The owners then, as a group, lease the flats to each other, resulting in a number of leases going across from the group (which is the

\footnotetext{
131 Gateway Flats "Submission” (20 March 1972), above n 117.

132 Pidgeon and Tappenden, above n 88 at 1216.

${ }^{133}$ Municipal Corporations Amendment Act 1958, s 3(2); Land Subdivisions in Counties Amendment Act 1958, s 2(2) cited in DW McMorland and Thomas Gibbons McMorland and Gibbons on Unit Titles and Cross Leases (LexisNexis, Wellington, 2013) at 97-98.

${ }^{134}$ McMorland and Gibbons, above n 133 at 97.

135 Timothy Orr "Inventor of Cross Lease Supports Legislation" Auckland District Law Society (online ed, 28 June 2013) <www.adls.org.nz>; also cited in Fredrickson, above n 1.

136 It is possible for the underlying land to be leasehold. When that happens, the cross-leases become subleases. This can give rise to complications, and generally banks see these titles less favourably. See McMorland and Gibbons, above n 133 at 99.
} 
Lessor) to individual owners, hence the expression "cross-lease". Each owner is therefore a Lessor and a Lessee at the same time.

The cross-lease title is a composite title as it is composed of a freehold ${ }^{137}$ and a leasehold estate. The Real Estate Authority, an independent government agency, called cross-lease titles "probably the most complicated form of property ownership in New Zealand" and warned that "lots of people struggle to understand them". ${ }^{138}$ Indeed, the composite nature of the title was a constant source of confusion for owners of cross-lease properties in Canterbury. ${ }^{139}$

In 1999, the Law Commission examined cross-lease properties and recommended that they be abolished. The Law Commission concluded that: ${ }^{140}$

The basic problem with the cross-lease system is perhaps public lack of awareness that there are problems. Most unit holders, it may be suspected, think of themselves as owning their units plus so much of the surrounding land as they may occupy to the exclusion of other unit holders (whether such exclusion rests on courtesy or custom or the rather sounder basis of a restrictive covenant). They may have been told by the kindly real estate agent on whose recommendation they bound themselves to their purchase that they would be "as good as" owners. But of course they are in fact neither owners nor as good as owners.

The Lessees do not have ownership of the flats, and their rights are determined by the terms of the lease. The rights and obligations of owners, the certainty, security, ease, and enforceability of their rights depend on the terms of the lease, which could vary from development to development.

\footnotetext{
${ }^{137}$ If the underlying title to the land is freehold; or leasehold if the land is leased.

${ }^{138}$ Real Estate Authority "What do you need to know about cross lease ownership" (online ed, 1 November 2018) <www.settled.govt.nz>.

139 Interview with Residential Risk Analysis; Interview with DLA Piper, Law firm (Emma Gabor, Wellington, 20 November 2017).

${ }^{140}$ Law Commission, above at n 44 at [9].
} 
The lease is generally for 999 years and is established by the payment of a peppercorn rent (something between $10 \mathrm{c}$ to $\$ 10$ ) at the beginning of the lease, with no further payments required. This is different from a standard lease, which requires ongoing payments. The fact that there are no ongoing payments means that there is no reminder to owners about their leasehold interest, leading people to imagine that they are outright owners of the units, and creating confusion about the nature of their ownership.

Until 1971 all cross-lease flats had to be in the same building but then it became possible to cross-lease any building, be it a flat in the same building, a semi-detached property or a standalone property. ${ }^{141}$ The different units are called "flats", regardless of whether they are describing a unit in a common building or a standalone house. In this study, I use both terms "units" and "flats" interchangeably.

Like company share schemes, cross-leases are largely a matter of private contract. However, there have been a few legislative changes to enable their functioning over the years. ${ }^{142}$ For example, in 1968, s 66A was introduced in the Property Law Act 1952 to clarify that a proprietor could create a lease to themselves. ${ }^{143}$ In 1971 , the Municipal Corporations Amendment Act added a deeming provision in s 350(4) of the Municipal Corporations Act 1954 to clarify that the granting of a lease or a disposition by way of a lease of a flat comprising of a different building was not a subdivision of land. ${ }^{144}$ The Local Government Act 1974 was amended in $1979^{145}$ to define the cross-leases as a form of land development ${ }^{146}$ and expressly exempted from the definition of "subdivision". ${ }^{147}$ This was reversed by the Resource Management Act 1991, which deemed cross-leasing a

\footnotetext{
${ }^{141}$ McMorland and Gibbons, above n 133 at 97.

142 Examples taken from Rod Thomas "Cross leases" in Elizabeth Toomey and JF Burrows (eds) New Zealand Land Law (3rd ed, Thomson Reuters, eBook, ProQuest Ebook, 2017) at 1137.

143 Property Law Act 1952, s 66A. This section was inserted in December 1968 by s 3 Property Law Amendment Act 1968.

${ }^{144}$ Municipal Corporations Act 1954, s 350(4).

${ }^{145}$ Local Government Amendment Act 1979.

${ }^{146}$ Local Government Act 1974, s 271(1).

147 Thomas, above n 142 at 1137.
} 
subdivision. ${ }^{148}$ Again, the government made legislative changes that either encouraged the creation of cross-lease properties or discouraged them (for example, the change in the Resource Management Act 1991).

\section{Prevalence}

Unlike company share schemes, cross-lease properties proved popular. A report commissioned by the Auckland City Council provides some useful numbers. ${ }^{149}$ As of March 2016, there were over 215,000 cross-lease properties in New Zealand. Nearly half are in Auckland. Nationally, cross-leases represent 10 per cent of the total number of property titles in New Zealand. Cross-leases are spread unevenly across the country. Auckland and Christchurch have the highest concentration. In each of these districts, crossleases represent 18 per cent of the local number of titles.

Broken down by numbers, Auckland has 100,148 titles, Christchurch 32,566, Tauranga 9,372, Hamilton 8,191, Wellington 4,999, Lower Hutt 4,799, Rotorua District 4,321, Taupō 3,265, Kāpiti District Coast 3,006, Dunedin City 2,951, and Upper Hutt 2,270. The remaining cross-lease titles are spread throughout the country in smaller numbers. ${ }^{150}$ There are two observations to make in relation to the breakdown by location. The first is to note the large number of cross-leases in Christchurch; this explains the size of the problem during the earthquakes. The second point to note is that, combined, the greater Wellington region has over 15,000 cross-lease titles. ${ }^{151}$ Wellington has a well-known seismic risk and, combined with a large number of cross-leases, it could face similar issues to Christchurch.

Cross-leases lost much of their attraction in 1991 when s 218 of the Resource Management Act 1991 stipulated that a cross-lease was a subdivision of land and had to comply with the same rules as freehold subdivisions. Cross-leases are still being created today, as it is

\footnotetext{
${ }^{148}$ Resource Management Act 1991, s 218(1)(a)(iv).

${ }^{149}$ Fredrickson, above n 1, Appendix A.

${ }^{150}$ All the numbers taken from Fredrickson, above n 1, Appendix A.

${ }^{151}$ The greater Wellington region includes not just the city of Wellington, but Lower Hutt, Upper Hutt and Kapiti Coast.
} 
cheaper to set up a cross-lease than to subdivide land. ${ }^{152}$ However, they are perceived as an inferior title to fee simple properties and generally sell at a discount ${ }^{153}$ so cross-lease developments are less popular. ${ }^{154}$

The Memorandum of Lease

The terms of the lease are contained in a Memorandum of Lease (Memorandum). The Memorandum sets out the rights and obligations of the Lessor and the Lessees. There are no set rules on what a Memorandum should contain. Parties are free to choose the terms of the lease, although in practice this means the developer is the one to set the rules, generally with the assistance of a lawyer. Given that cross-lease titles have been in use since the 1960s, there is variety in the terms of the Memoranda. For ease of reference, throughout the thesis, I refer to the terms contained in the ADLS Standard Form Lease (ADLS CrossLease 1989). I have chosen this version because it is set out in full in a major textbook, New Zealand Land Law so it is accessible to others. ${ }^{155}$

The Memorandum contains covenants about keeping the property in good repair ${ }^{156}$ and arranging insurance. ${ }^{157}$ Compared to fee simple properties, the owners of a cross-lease title have fewer rights and more obligations. Most of the Memoranda contain dense legal jargon, which is often difficult to understand. Scholars note with concern that owners either

\footnotetext{
152 Thomas, above $\mathrm{n} 142$ at 1138 .

${ }^{153}$ For a full discussion on the level of the discount, see Michael Rehm "Double Crossed: The Discounting of Cross Lease Properties in Auckland" (paper presented to Pacific Rim Real Estate Society Conference, Lincoln, New Zealand, 19 January - 22 January 2014). His conclusion was that across all section sizes, properties with two joint owners suffer a 3.5 per cent price discount compared to freehold equivalents, two shares 5 per cent, four shares 6.5 per cent and a discount of 7.5 per cent for cross lease properties with five or more joint owners.

${ }^{154}$ Fredrickson, above $\mathrm{n} 1$ at 92.

155 Rod Thomas, above n 142 at 1205-1209.

156 ADLS Cross Lease, cl 6.

${ }^{157}$ ADLS Cross Lease, cl 12.
} 
systematically ignore or misunderstand the covenants in the Memorandum of Lease, considering their title to be the equivalent of a freehold title. ${ }^{158}$

A complicating factor about cross-lease titles is that it is unclear which covenants are binding on owners. There are different outcomes depending on how the cross-lease was set up and the date when the transfer of the lease occurred. ${ }^{159}$ This is because a lease is both a contract and a grant of a leasehold estate in land. ${ }^{160}$ There is therefore privity of contract (lease) and privity of estate (leasehold) between the Lessor and the Lessee. However, if an original developer leases the flats to themselves in the first instance (as it is usually the case, pending sale) there cannot be privity of contract. This raises the question on what covenants are passed to the first purchaser of the cross-lease. What covenants are binding on the subsequent purchaser depends on the timing of the transfer. ${ }^{161}$ For transfers that came into operation on or after 1 January 2008, all covenants are binding pursuant to s 240 of the PLA 2007. However, given that cross-leases were more popular before 1991, it is likely that most of them do not benefit from the clarity brought by the PLA 2007. The short point here is that cross-leases are complicated titles and enforcing the title covenants is not straightforward.

Scholars have highlighted the difficulties with cross-leases, noting that arbitration is often the only way of resolving disputes, with inconsistent outcomes, and that taking Lessees to court is difficult as the remaining lessors must act in unison. ${ }^{162}$

There is no overarching legislation regulating cross-leases; the relationship between the parties is controlled by the terms of the Memorandum of Lease, "which may be silent on important aspects of that relationship."

\footnotetext{
${ }^{158}$ Pidgeon and Tappenden, above n 88 at 1216.

${ }^{159}$ McMorland and Gibbons, above n 133 at 111.

${ }^{160}$ McMorland and Gibbons, above n 133 at 111.

${ }^{161}$ McMorland and Gibbons, above n 133 at 111.

162 Pidgeon and Tappenden, above n 88 at 1216.

${ }^{163}$ Pidgeon and Tappenden, above n 88 at 1216.
} 
Different to fee simple titles, it is believed that there is no presumption that the ownership extends to the sky or goes down to the centre of the earth. ${ }^{164}$ Ownership is delineated by the exterior walls, foundation, and roof of the flat as described in the lease documents. ${ }^{165}$ The underlying land and the airspace above are common property. That means that changes to the outer walls of the flat are an encroachment on the title space. ${ }^{166}$ The changes need to be consented by the other owners (that is, the Lessor). Cross-lease titles impose very strong decision dependencies on owners.

The Memorandum stipulates how decisions are made. Sometimes, the Memoranda will state that decisions need to be achieved by a "majority of the lessors", and sometimes it will require the consent to be unanimous. ${ }^{167}$ Some Memoranda stipulate that consent cannot be withheld unreasonably, and sometimes they stipulate that consent is required for all alterations, not just for structural changes. ${ }^{168}$ It is not straightforward to determine what constitutes "majority" in the case of small developments (for example, developments of two or three units), or where one proprietor owns more than one unit in the development. ${ }^{169}$ It is also not straightforward to determine when can an owner withhold consent. ${ }^{170}$

There are two related points to make here. The first is that owners need to consult with the others in order to change the outline of their flat or do any structural work inside their

\footnotetext{
164 Thomas, above n 142 at 1142; this book also cites Wellington v Hickling HC New Plymouth M19/95, 10 April 1995 and Douglas v Cammock HC Hamilton, CP48/99, 4 August 1999.

${ }^{165}$ Wellington $v$ Hickling, above n 164, where the Court said that the "essence of the cross lease is that the area of the lease extends to the parameters of the area described... any extension of the lease will therefore be an encroachment onto common property ... and will therefore affect title". In Douglas v Cammock, above n 164 the Court said that "the plan purports to depict the outer parameters of the leased area to enable identification...what is leased is the actual flat as it existed at the date of the cross lease."

166 Thomas, above n 142 at 1176.

167 Thomas, above $\mathrm{n} 142$ at 1177.

168 Thomas, above n 142 at 1177.

${ }^{169}$ See discussion in Thomas, above n 142 at 1162-1165.

${ }^{170}$ See discussion in Thomas, above $\mathrm{n} 142$ at 1180-1184.
} 
flat. ${ }^{171}$ Owners cannot demolish their flat and build a new one without the consent of the other flat owners. ${ }^{172}$ The procedure for obtaining consent and making decisions is complicated. The upshot is that an insurance company standing on the rights of an owner with a damaged flat would need to obtain consent from the other flat owners for any structural repair works and would face the same difficulties in obtaining consent.

The second point is that if an owner makes any changes to the outline of the flat, the owner needs to deposit a new flats plan with the Land Registrar showing the amended flat for which the lease is granted. This is a costly exercise that requires input from a surveyor to determine the new flat outline, and a lawyer to issue new cross-lease titles. Failure to comply with these obligations makes the cross-lease title defective. Defective cross-lease titles were a serious problem in Canterbury and affected the resolution of some insurance claims. $^{173}$

Given the strong decision dependency, it is unsurprising that the Memorandum imposes some decision-making mechanisms and management rules. In theory, these rules should enable the bare functioning of the cross-lease community. However, the management of cross-lease title presents three problems. First, the terms of the Memoranda are difficult to understand. The language is archaic and hard to read. This exacerbates the confusion about the rights and responsibilities that come with the title. The second problem is that sometimes decision-making requires unanimity, and this is difficult to achieve. The third problem is that the prescribed dispute resolution mechanism is usually arbitration. This is an expensive and adversarial process unsuitable to resolve disputes between neighbours. I examine these problems in Chapters IV and V when I investigate the experience at the time of the Canterbury earthquakes.

\footnotetext{
${ }^{171}$ Note, however, that cosmetic, decorative or superficial alterations do not generally require consent from the other Lessees. For further discussion and guidelines for determining which works are structural and require consent see Estate D B Ferguson v Walsh (1999) 4 NZ ConvC 193,032.

${ }^{172}$ Douglas $v$ Cammock, above n 164. In this case, Cammock gave notice that he intends to demolish the flat and build a new one. After a while, he gave notice that he just wants to demolish but not rebuild immediately. The Court held that Cammock needed the consent of the other owner before he could demolish the flat.

${ }^{173}$ Interview with Young Hunter; Focus Group discussion; Interview with EQC, Statutory Insurer (Emma Gabor, via Zoom Christchurch / Wellington, 2 July 2020); Interview with Residential Risk Analysis.
} 
There are two final observations to make on cross-lease titles.

The first is that this legacy system created thousands of cross-lease titles that need to be contended with now.

The second observation is that cross-leases are cheaper to create than fee simple. ${ }^{174}$ This has the advantage of providing more affordable properties. But it has two unintended consequences. The first is that affordability comes at a cost. The titles are complicated. There are significant repair and decision dependencies. Ultimately, cross-leases properties have a lower dollar value but a higher human cost.

The second unintended consequence is that a cheaper price means they are more attractive to a certain class of buyers. One of these is landlords. Because the properties are cheaper to buy, they make good rental properties as they provide a higher return relative to the investment. ${ }^{175}$ Unlike most company share schemes that prevent letting out the units, there is no such restriction for cross-leases. But absentee landlords often have different interests to owner-occupiers, which is to maximise returns rather than to ensure the best possible living conditions. In a development that requires unanimity of decision, a prevalence of absentee landlords can cause problems. This very point became significant during the Canterbury earthquakes, and I express concern about the existence of different interests in Chapter V where I propose solutions to the problem. And on the same point, I need to add something else. It is not only landlords who are attracted to cross-leases. The lower cost often attracts vulnerable groups that cannot afford a standalone property. There was evidence from Canterbury that cross-lease properties attracted vulnerable people, such as

\footnotetext{
${ }^{174}$ See McMorland and Gibbons, above n 133 at 131, due to lower survey costs; lower financial contributions by developers under certain district plans, less restrictions applicable under certain district plans; ready-made covenants available to import into a new cross-lease, no need to draft and include easements for right of way and easements for services.

${ }^{175}$ Fredrickson, above $\mathrm{n} 1$ at 22.
} 
the elderly, mentally ill, or people in a precarious financial situation. ${ }^{176}$ This adds a level of complication in managing insurance claims for a cross-lease development. I return to these issues in Chapter IV.

\section{Insurance}

Memoranda will invariably require the Lessees to insure their flats. Such a requirement is wise and becomes imperative when the flats are in the same building or abutting each other. When one flat is damaged and left unrepaired, the other flats suffer as a result. This could be loss of structural support or simply loss of value caused by unsightly damage.

Where all the flats are in the same building, some Memoranda require them to be insured together. It makes sense to have the entire building insured together as that allows an insurer to have the control necessary to carry out the repairs. ${ }^{177}$ Such a requirement acknowledges the repair dependencies that exist where units are built within the same building envelope. It appears that the inventor of the cross-lease titles intended for the units to be insured under one insurance policy but that subsequent lawyers using the cross-lease mechanism have ignored this stipulation. ${ }^{178}$

Even where there were covenants imposing an obligation for joint insurance, some flat owners ignored their obligations and had different types of policies, with different insurance companies. ${ }^{179}$ Scholars warned that this was likely to lead to delays in actioning claims. ${ }^{180}$ Indeed, in Canterbury, the existence of multiple insurers for different units in the same building was a major cause of delay, and I discuss this in Chapter IV.

\footnotetext{
${ }^{176}$ Interview with Residential Risks Analysis; Interview with RAS; Interview with EQC; and Toomey Finn research paper, above n 26 at 21.

${ }^{177}$ McMorland and Gibbons, above n 133 at 113.

${ }^{178}$ Pidgeon and Tappenden, above n 88 at 1217.

${ }^{179}$ McMorland and Gibbons, above n 133 citing NZLS Seminar, Cross Leases, (1994), 63 at 65-66 and 68 (Merfield).

${ }^{180}$ McMorland and Gibbons, above n 133 NZLS Seminar, Cross Leases, (1994), 63 at 65-66 and 68 (Merfield).
} 
If cross-leases are subject to a mortgage, the mortgagee can direct whether the insurance payment is used for reinstatement or toward payment of the debt. ${ }^{181}$ This is significant because banks might not release the money for repairs, which would leave the unit owners unable to carry out the reinstatement.

\section{F Unit Titles \\ $1 \quad$ Nature of the title}

The last type of title examined in this chapter is the unit title. Unit titles are a "unique species, quite different in nature from fee simple titles, cross-leases, and company shares schemes". ${ }^{182}$ They were first established by the UTA 1972 but are currently regulated by the Unit Titles Act 2010 (UTA). They cannot exist unless created according to the Act. Unit titles are also known as strata titles, stratum estates, ${ }^{183}$ or apartments.

The purpose of the UTA 1972 was to facilitate the subdivision of land into units, ${ }^{184}$ encourage strata title developments, ${ }^{185}$ and resolve any perceived issues with cross-leases and company share schemes. ${ }^{186}$

\footnotetext{
${ }^{181}$ PLA 2007, Schedule 2, cl 3(1).

182 Thomas Gibbons Unit Titles Act and Practice (2nd ed, LexisNexis, Wellington, 2015) at 9.

183 The word "strata" or "stratum" refers to the fact that the apartments are arranged on horizontal layers.

${ }^{184}$ Section 3.

${ }^{185}$ Wilson v Turnwald (1997) 3 NZ ConvC 192, 559 at [6]. This case involved a three-unit development where two owners were family members and the third was a purchaser. The judge found that the application of UTA 1972 to a small unit development was quite awkward and this case was a good example of it. Turnwald wanted to build a garage but Wilson opposed it. The Court said that Turnwald could not build the garage he proposed as it did not have the majority consent (it did have two out of three votes but that equated to 66 per cent of the majority votes and the Act required 80 per cent majority. The Court pointed out that there would have to be five units before a majority of 80 per cent could be obtained and while this might seem unfair, it was Parliament's decision.

${ }^{186}$ Gibbons Unit Titles Act, above n 182 at 1; Department of Justice "Comments on the Flat and Office Ownership Bill" (undated) located in Archive New Zealand file titled "36th Parliament - Statutes Revision Committee - Bills - Public Bills - Unit Titles [Session 3]”, Archive ref ABGX W3706 16127 Box 29.
} 
A lot of thought went into debating the Flat and Office Ownership Bill 1972, which passed under the name UTA 1972. In presenting the report from the Statutes Revisions Committee to the House of Representatives, Sir Leslie Munro recognised the advancement brought by this new form of ownership. Quite fitly, he heralded: ${ }^{187}$

We are living now in an age of transition. I am reminded of the statement which Eve is supposed to have made to Adam when they left the Garden of Eden, "My dear Adam, we are living in an age of transition." In this country we are probably moving from the front-yard and back-yard concept of life to the flat and apartment concept, with people going out in the country in the weekends.

The Bill has been considered very carefully [and] the proposed amendments are concerned with practical details designed to make the scheme provided for in the Bill operate more smoothly.

The Flat and Office Ownership Bill was before Parliament for two years before it passed. Different interest groups had time to make submissions, anticipating what could go wrong. ${ }^{188}$ This is to be contrasted with the informal development of the company share schemes, cross-lease titles and fee simple townhouses.

The UTA 1972 modelled similar legislation introduced in the 1960s in the Australian states of New South Wales and Victoria. ${ }^{189}$ When teething problems appeared, in 1979, Parliament passed amending legislation to correct some of the perceived difficulties

\footnotetext{
187 (14 July 1972) 379 NZPD 1089.

188 There were submissions from company share scheme owners and managers, Fletcher Development, the Department of Justice, NZLS, Wellington City Council, the Associated Chamber of Commerce, New Zealand Master Builders' Federation and others.

189 Chris Moore and Michael Goodger "Maintenance issues and strata title legislation and proposals for reform" (online ed, 15 August 2008) <www.internationallawoffice.com/Newsletters/Real-Estate/NewZealand/Meredith-Connell/Maintenance-Issues-under-Strata-Title-Legislation-and-Proposals-for-Reform>. Also see references to Australian legislation during submissions on the Flat and Office Ownership Bill 1972 by LH McClelland, Registrar-General of Land to the Law Draftsman, 1 August 1969, located in document titled "Homeowners and Householders Insurance - Insurance under Unit Titles Act 1972", Archive New Zealand, archive reference AAXF W3614 23322 Box 63.
} 
including allowing for staged developments, ${ }^{190}$ clarifying the requirements for certificates for a deposit of plan; ${ }^{191}$ changing the class of risk for which the Body Corporate had to have insurance; ${ }^{192}$ and resolving a conflict between ss 9 and 17 in the original Act. ${ }^{193}$

The amendments illustrate the differences between a statutory property title and other property titles. With statutory property titles, there is capacity to introduce changes that apply universally. And even temporary changes could be introduced. For example, in 2020, in light of the lockdown caused by the Covid-19 pandemic, the government made temporary changes to the UTA to allow Body Corporates to hold meetings remotely. ${ }^{194}$

There is always a likelihood of teething problems when creating something as complicated as a new property title. Thus, the ability to correct problems is important.

A stratum estate is multi-faceted. It consists of an underlying estate in the land (which can be freehold, leasehold, or licence estate), a beneficial interest in the common property, and a contingent entitlement to the undivided share of the fee simple, leasehold, or licence upon cancellation of the unit plan. ${ }^{195}$ These different facets, sometimes described as a "bundle of rights" 196 are indivisible. ${ }^{197}$ Despite this multi-faceted aspect, there was little evidence from the empirical research to suggest that owners did not understand the type of title they owned. The exception was small Body Corporates which did not have a Committee and

\footnotetext{
${ }^{190}$ Unit Titles Amendment Act 1979.

191 Section 13.

192 Section 16.

193 Section 17.

${ }^{194}$ COVID-19 Response (Further Management Measures) Legislation Act 2020, Schedule 12, cl 2.

195 Gibbons Unit Titles Act, above n 182 at 18.

196 Gibbons Unit Titles Act, above n 182 at 31.

197 Attorney-General v Body Corporate 68792 (2007) 8 NZCPR 165 at [40]. This case involved the Crown wanting to compulsorily acquire part of a unit title development for the purpose of building a ramp to a motorway interchange in Petone, Lower Hutt. It appears that only $1,171 \mathrm{~m}^{2}$ of the $6,836 \mathrm{~m}^{2}$ was required for the public works and the Crown (Tranzit NZ) did not want to acquire the whole property. Although the case refers to the provisions of the UTA 1972, the situation is similar under UTA.
} 
owners were acting independently of each other. ${ }^{198}$ However, the Toomey Finn research paper found that owners' understanding of how the unit title regime works was "very limited". 199

In terms of numbers, again, the report commissioned by Auckland City Council is of assistance. ${ }^{200}$ As of March 2016, there were over 143,000 unit title titles in New Zealand. ${ }^{201}$ That represents 7 per cent of the total number of property titles in the country. Unsurprisingly, Auckland has the highest number of unit titles, 75,376 in total or 52 per cent of the national total. Wellington City has 18,453, Christchurch City 12,378, Queenstown Lakes District Council 6,566, Hamilton 5,669, Tauranga 3,465, Dunedin 2,226, and Lower Hutt 1,959. Wellington and Queenstown have the highest concentration of unit title developments, with 22 per cent of the total titles being unit titles in Wellington, followed closely by Queenstown with 21 per cent.

\section{The Body Corporate}

The UTA provides for the establishment of a Body Corporate that holds the common property and has various powers and responsibilities. The Body Corporate is made of all owners of the units on the plan.

A Body Corporate may do anything authorised by the UTA or any other Act and may do anything a natural person of full age and capacity may do except as provided for in the UTA or any other Act. ${ }^{202}$ However the Body Corporate's actions must be for performing its duties or exercising its powers. ${ }^{203}$

\footnotetext{
${ }^{198}$ Interview with specialised contractor with Residential Advisory Services (Emma Gabor, Christchurch, 28 May 2019) [Interview with specialised contractor with RAS]; Interview with EQC.

199 Toomey Finn research paper, above n 26 at 14.

${ }^{200}$ All the numbers in this section are taken from Fredrickson, above $n 1$ at 131.

${ }^{201}$ All the numbers in this section are taken from Fredrickson, above $n 1$ at 131.

202 UTA, s 77.

${ }^{203}$ UTA, s 78.
} 
The Body Corporate is charged with administering the unit title development. Relevant to this study are the requirements to keep a register of owners, ${ }^{204}$ to act as an agent for the owners who lease their unit and are absent (if this is needed for the purpose of enforcing the Body Corporate rules); ${ }^{205}$ and to sign documents on behalf of the owners in certain circumstances. ${ }^{206}$ Keeping a register of owners is important especially where there are absentee owners (landlords). Given the decision dependencies, it is important for owners to be able to contact each other easily. In Chapter IV, I discuss the difficulties encountered by cross-lease properties in Canterbury where there were absentee owners.

The Body Corporate has the power and the duty to call general meetings to address matters of interest for the development. ${ }^{207}$ This enables owners to exercise the decision dependency.

The Body Corporate has an obligation to adopt Body Corporate rules which serve as management rules for the community. The members of the Body Corporate vote on the rules, which is likely to assist in making the rules more widely known.

The Body Corporate must also establish and maintain a long-term maintenance plan. This is important for the maintenance of the building.

\footnotetext{
${ }^{204}$ UTA, s 85.

${ }^{205}$ UTA, s 81.

${ }^{206}$ UTA, s 86.

${ }^{207}$ UTA, s 90.
} 
The owners have a share in the common property; ${ }^{208}$ the right of quiet enjoyment of their unit; $^{209}$ the right to attend the Body Corporate meetings ${ }^{210}$ and vote at the meetings; ${ }^{211}$ they can enforce the Body Corporate operational rules, ${ }^{212}$ and invoke the dispute resolution provisions in the UTA in case of a dispute. ${ }^{213}$ They can also make alterations and additions to their units as long as these are within the unit's boundaries and do not materially affect any other unit or the common property. ${ }^{214}$

Owners must allow the Body Corporate to enter the unit at any time in an emergency and at all reasonable hours, and after giving reasonable notice, to view the condition of the unit for the purpose of ascertaining compliance with the principal unit owners' or occupiers' obligations under the UTA; $;^{215}$ or to maintain, repair, or renew any infrastructure for services and utilities that serve more than one unit and any building elements that affect more than one unit or the common property; ${ }^{216}$ or to maintain, repair, or renew any common property ${ }^{217}$ or to ensure the Body Corporate operational rules are being complied with. ${ }^{218}$ Owners must comply with the Body Corporate operational rules and must take steps to give them effect; ${ }^{219}$ must comply with the relevant laws when using their unit; ${ }^{220}$ must consult with his or her mortgagee, if required to do so, before exercising a vote under s 97 or 98 of

\footnotetext{
${ }^{208}$ UTA, s 79(b).

${ }^{209}$ UTA, s 79(d).

${ }^{210}$ UTA, s 79(h).

${ }^{211}$ UTA, s 79(c).

${ }^{212}$ UTA, s $79(\mathrm{~g})$.

${ }^{213}$ UTA, s 79(f).

${ }^{214}$ UTA, s 79(e).

${ }^{215}$ UTA, s 80(1)(a)(i).

${ }^{216}$ UTA s 80(1)(a)(ii).

${ }^{217}$ UTA, s 80(1)(a)(iii).

${ }^{218}$ UTA, s 80(1)(a)(iv).

${ }^{219}$ UTA, s 80(1)(b).

${ }^{220}$ UTA, s 80(1)(d).
} 
the UTA; ${ }^{221}$ must carry out, without delay, all work that may be ordered by a territorial authority or public body in respect of the unit to the satisfaction of that authority or body; ${ }^{222}$ must pay all rates, taxes, charges, Body Corporate levies, and other outgoings that are from time to time payable in respect of the unit; ${ }^{223}$ must repair and maintain the unit and keep it in good order to ensure that no damage or harm, whether physical, economic, or otherwise, is, or has the potential to be, caused to the common property, any building element, any infrastructure, or any other unit in the building ${ }^{224}$ must notify the Body Corporate of his or her intention to carry out any additions or structural alterations before the commencement of any work; ${ }^{225}$ must not make any additions or structural alterations to the unit that materially affect any other unit or the common property without the written consent of the Body Corporate; ${ }^{226}$ must comply with the Body Corporate operational rules; ${ }^{227}$ must not do anything that breaches or in any way undermines any policy of insurance in the name of the Body Corporate. ${ }^{228}$

The long list of provisions reflects the reality of living in a community. There are rights, but also extensive obligations and responsibilities to ensure that everybody in the community can enjoy their unit. Unlike in a fee simple situation, unit owners are not free to let their unit fall into disrepair.

\footnotetext{
${ }^{221}$ UTA, s 80(1)(c).

${ }^{222}$ UTA, s 80(1)(e).

${ }^{223}$ UTA, s 80(1)(f).

${ }^{224}$ UTA, s 80(1)(g).

${ }^{225}$ UTA, s 80(1)(h).

${ }^{226}$ UTA, s 80(1)(i).

${ }^{227}$ UTA, s 80(1)(j).

${ }^{228}$ UTA, s 80(1)(k).
} 


\section{$4 \quad$ Management of a Body Corporate}

The UTA has been built around democratic principles. ${ }^{229}$ This includes rules and procedures for organising meetings, ${ }^{230}$ appointing a representative chairperson ${ }^{231}$ and a committee ${ }^{232}$ and adopting and enforcing organisational rules. ${ }^{233}$ This arises out of the need to synthetize the conflicting views, needs and desires of proprietors and enable them to make collective decisions about the common property. ${ }^{234}$

To enable proper administration of a Body Corporate, the Act provides for the election of a chairperson. The chairperson has extensive obligations ${ }^{235}$ and is likely to delegate or contract out some of these duties.

Where a development has ten or more principal units, the Body Corporate must form a committee unless the Body Corporate decides otherwise by special resolution. ${ }^{236}$ Developments with nine or fewer principal units may form a committee if they want to but there is no requirement for them to do so. The experience in Canterbury was that sometimes Body Corporates that did not have a committee were not able to function adequately. ${ }^{237}$

\footnotetext{
${ }^{229}$ Gibbons Unit Titles Act, above n 182 at 56.

230 These meetings can be annual general meetings or extraordinary general meetings.

${ }^{231}$ UTA, s 89(2).

${ }^{232}$ UTA, s 112.

${ }^{233}$ UTA, s 105.

${ }^{234}$ World Vision of New Zealand Trust Board v Seal [2004] 1 NZLR 673 at [51].

235 These include the obligation to maintain the current register of unit owners, prepare the agenda for each general meeting; chair each annual meeting; prepare minutes of each meeting including records on voting; keep financial accounts; receive reports from the committee, distribute reports to the unit owners; sign documents on behalf of the Body Corporate; prepare and issue notices of resolutions to be passed without a meeting and notify owners of such resolutions passed; notify the committee of any power delegated to the committee by the Body Corporate; any other administrative duties imposed by ordinary resolution of the Body Corporate. This list of duties is taken from Gibbons Unit Titles Act, above n 182 at 66-67.

${ }^{236}$ UTA, s 112.

${ }^{237}$ Focus group discussion; Interview with Grant Shand Barristers and Solicitors, Insurance Lawyers (Emma Gabor, Christchurch, 28 November 2017).
} 
Unsurprisingly, having a strong leadership means there is a better way of managing the collective affairs of a group linked by repair and decision dependencies. ${ }^{238}$

Unit titles are not perfect. They have been criticised for abuses in exercising voting, lack of drive to effect repairs, delays leading to large maintenance issues, large Body Corporate fees, and insufficient disclosure obligations at the time of sale. ${ }^{239}$ In March 2021, while introducing the Unit Titles (Strengthening Body Corporate Governance and Other Matters) Bill, Hon Nicola Wills MP told the members that "things have got so bad that some developers are choosing to bypass the Act entirely by creating bespoke legal structures."240

The UTA is currently under review. ${ }^{241}$ The review relates to a number of matters including improving the disclosure regime of information to prospective purchasers; ${ }^{242}$ power to issue improvement notices; ${ }^{243}$ original owner's obligation in relation to service contracts $;{ }^{244}$ enabling electronic voting; ${ }^{245}$ enlarging the jurisdiction of the Tenancy Tribunals and the District Court to hear disputes; ${ }^{246}$ and others.

The overall intent of the legislative review is to "make life easier for the thousands of people currently living in multi-unit dwellings". ${ }^{247}$ There have been a number of submissions made on the Unit Titles (Strengthening Body Corporate Governance and

\footnotetext{
238 See the discussion in Chapter V, Part A4.

239 Toomey Finn research paper, above n 26 at 248; Ben France-Hudson "Review of the Unit Titles Act 2010: A Missed Opportunity” (2017) ", Otago Law Review (15 Otago LR 147L. Rev, online ed, 2017) at 151; Dileepa Fonseka, above n 65; Jeremy Finn, Ben France-Hudson and Elizabeth Toomey "Damage, Destruction, Distress", above n 83.

240 (10 March 2021) 750 NZPD 1296.

${ }^{241}$ Susan O’Neill, Principal Policy Advisor, Ministry of Housing and Urban Development “Apartment/Condo Regulation, Management and Future Trends: New Zealand's Unit Titles Act” (webinar, 15 December 2020) at 4 .

242 Clauses $7 \mathrm{~B}$ and 18.

243 Clause 21C.

${ }^{244}$ Clause 17.

245 Clause 10.

${ }^{246}$ Clauses 21, 21A and 21B.

247 (10 March 2021) 750 NZPD 1296.
} 
Other Matters) Bill 2021 including from the New Zealand Law Society (NZLS) ${ }^{248}$ and ICNZ. ${ }^{249}$ The thesis supports the current proposals to strengthen the governance of Body Corporates, in particular those amendments that make it easier for owners to make decisions and have the disputes resolved promptly.

\section{$5 \quad$ Dispute resolution mechanisms}

The UTA sets out a three-tiered dispute resolution scheme for unit titles. This is made of the Tenancy Tribunal, District Court and the High Court. The reason for the three-tiered structure is "to provide access to a cost-effective, appropriate and timely dispute-resolution process and enforcement regime for unit title disputes." ${ }^{250}$ Under s 171, the Tenancy Tribunal has jurisdiction to hear unit title disputes for a claim not exceeding $\$ 50,000$. The Tenancy Tribunal does not have jurisdiction to hear matters related to the title of land or to hear a dispute related to the application of insurance money. The cost to have the claim heard in the Tenancy Tribunal depends on the matter to be heard. Regulation 5 of the Unit Titles (Unit Title Disputes-Fees) Regulations 2011 sets the filing fees at $\$ 3,300$ incl GST for a category one proceeding, and $\$ 850$ incl GST for a category two proceeding. Regulation 6 defines category one proceedings as proceedings for a unit title dispute that, because of its average or high complexity, is likely to involve a hearing before the Tenancy Tribunal as the principal means of resolving the dispute. A category two proceeding means proceedings for a unit title dispute of a straightforward nature that, because of its low complexity, is likely to involve mediation as the principal means of resolving the dispute.

The District Court has jurisdiction to hear and determine a unit title dispute between $\$ 50,000$ and $\$ 350,000$ and a dispute relating to the application of insurance money for

\footnotetext{
${ }^{248}$ NZLS Submission on the Unit Titles (Strengthening Body Corporate Governance and Other Matters) Bill 3 May $2021<w w w . l a w s o c i e t y . c o . n z>$.

${ }^{249}$ ICNZ Submission on the Unit Titles (Strengthening Body Corporate Governance and Other Matters) Amendment Bill (29 April 2021) <www.parliament.nz/resource/enNZ/53SCFE_EVI_99361_FE1389/c9f83bc320ea296266a4c1005a9e96ac44a20b68>.

${ }^{250}$ MBIE: Tenancy Services website <www.tenancy.govt.nz>.
} 
amounts up to and including $\$ 50,000 .{ }^{251}$ The District Court does not have jurisdiction to hear any dispute relating to the title of land.

The High Court has jurisdiction to hear and determine any unit title dispute for more than $\$ 350,000$ or a dispute relating to the title of land. In relation to application of insurance money, it has jurisdiction for disputes involving more than $\$ 50,000$.

\section{$6 \quad$ Insurance}

The UTA requires a Body Corporate to keep the buildings insured at all times to the full insurable value. ${ }^{252}$

The Toomey Finn research paper points out that it is unclear how the requirement for "full insurance value" should be interpreted in the situation where a Full Replacement Value policy is available in the market but is prohibitively expensive. It argues that it is unclear whether the word "available" means "available at all" or "available at a reasonable cost". 253 The paper points out that, post-earthquake, there were significant price fluctuations, and gives the example of a Body Corporate whose insurance premiums increased from $\$ 45,000$ to $\$ 500,000 .^{254}$

In 2021, in their submission on the Unit Titles (Strengthening Body Corporate Governance and Other Matters) Bill 2021, NZLS pointed out to the same difficulty and suggested clarification of the insurance provisions. The submission stated that the "earthquakes have caused issues around the availability and cost of insurance cover leading to body corporates

\footnotetext{
${ }^{251}$ Section 172.

${ }^{252}$ UTA, s 135.

253 Toomey Finn research paper, above n 26 at 209-210.

254 Toomey Finn research paper, above n 26 at 209-210.
} 
facing difficult insurance decisions." 255 It submitted that there is uncertainty about the phrase "not available in the market". 256

One interviewee, a property lawyer, made a similar remark, noting that the provisions of the UTA are confusing and inconsistent, in some parts referring to "full insurable value" and in others referring to "replacement insurance"; ${ }^{257}$ the interviewee also noted that the removal of listed insurable perils from the UTA 1972 Act meant that, arguably, it would be possible for Body Corporates to insure for "full insurable value" without insuring for earthquake risk for example. ${ }^{258}$

The Toomey Finn research paper claims that "the move by insurers to 'Sum Insured' policies complicates matters further, as these policies will not necessarily provide for Full Replacement." 259 With respect, that statement is inaccurate. First, material damage policies for Body Corporates have always been subject to a Sum Insured. There has been no change since the Canterbury earthquakes in relation to the type of cover available for Body Corporates. Second, the basis of indemnity of a Sum Insured policy is new-for-old (similar to the standard of reinstatement in a Full Replacement policy) but subject to the Sum Insured stated in the schedule. Therefore, it is possible for a Body Corporate to insure for full replacement value and receive full reinstatement costs if it sets the Sum Insured at an adequate level. Chapter III discusses in detail the differences between insurance policies.

But it is true that if a Body Corporate is not careful in selecting the right level of cover, it can leave a Body Corporate underinsured. There are multiple examples arising out of the Canterbury earthquakes where that was the case, and I will discuss these cases in Chapter IV.

\footnotetext{
255 NZLS “Submission on Unit Titles (Strengthening Body Corporate Governance and Other Matters) Bill 2021 (3 May 2021) <www.lawsociety.co.nz> at [91].

256 NZLS “Submission”, above n 255 at [92].

${ }^{257}$ Interview with Greenwood Roche, Law Firm (Emma Gabor, Wellington, 28 January 2020).

${ }^{258}$ Interview with Greenwood Roche.

${ }^{259}$ Toomey Finn research paper, above n 26 at 210.
} 
Money paid by the insurer under the principal insurance policy must be applied toward reinstatement of the unit title development unless the Body Corporate decides otherwise by special resolution at a general meeting. ${ }^{260}$ This provision is important and in contrast with the obligations imposed on fee simple owners who are not required to apply the insurance proceeds toward reinstatement (unless special covenants impose such obligation).

If the Body Corporate applies the insurance money toward reinstatement, then a mortgagee is not entitled to demand that any part of the money be applied in or toward repayment of the mortgage debt. ${ }^{261}$ This is a valuable provision because it prioritises the reinstatement of the property (to the benefit of the whole community) over the debts of an owner. Crosslease properties and fee simple townhouses do not benefit from such protection. As such, if an insurance company makes a payment to a cross-lease or a fee simple owner, the bank can choose to apply that money toward payment of the mortgage, leaving the owner short for the repair costs.

The Body Corporate must keep the insurance records up to date by listing the current unit owners on the policy schedule at each policy renewal (which occurs annually). ${ }^{262}$ That helps keep the register of owners up to date, which is important when decisions need to be made collectively and owners need to be contacted.

Where the principal and accessory unit on a plan are standalone units, the Body Corporate may pass a special resolution requiring each owner to insure individually. ${ }^{263}$ In that case, the Body Corporate will only be responsible for the common property. In its submission on the Unit Titles (Strengthening Body Corporate Governance and Other Matters) Bill 2021, NZLS argued that the meaning of "standalone units" require clarification. It suggested that it would be better to allow "owners within different building blocks to take

\footnotetext{
${ }^{260}$ UTA, s 136(4).

${ }^{261}$ UTA, s 136(6).

262 This occurs yearly.

${ }^{263}$ UTA, s 137(2)(a).
} 
out their own insurance cover, as a body corporate could comprise a series of duplexes or different townhouse blocks which do not necessarily need to be insured together." ${ }^{264}$ It noted that, in practice, many small Body Corporates without a body corporate manager arrange independent insurance whether they are standalone or not.

\section{Mixed-use developments}

Developments where commercial and residential uses are mixed into one building are becoming more common. A classic example is a building that has commercial retail space on the ground floor and residential units on the upper floors. For larger developments, these could involve other areas such as car-parking or entertainment, or even industrial areas. Mixed-use buildings are generally structured as a unit title development ${ }^{265}$ although they can be developed as fee simple. There are no special legislative provisions to deal with the mixed-use developments. The Canterbury and the Kaikōura earthquakes posed some difficulties with insurance claims for mixed-used buildings because EQC does not insure commercial properties. There were some uncertainties on how to calculate EQC's contribution. ${ }^{266}$

The thesis does not examine mixed-use buildings for two reasons. First, the thesis focuses on residential properties. Second, complexities encountered due to mixed-use element are a large topic of its own. In March 2020, a Cabinet paper revealed that Treasury was undertaking work in revising the EQC Act to provide better treatment for mixed-use buildings. ${ }^{267}$

\footnotetext{
${ }^{264}$ NZLS "Submission", above n 255 at [93].

265 Toomey Finn research paper, above n 26 at 248.

266 Treasury - Cabinet Paper "Mixed-use Buildings Under the Earthquake Commission Act 1993" (10 March 2020) DEV-20-SUB-0039<www.treasury.govt.nz/system/files/2020-12/mixed-use-buildings-eqc-dev-20sub-0039.pdf>.

267 Treasury "Mixed-use buildings", above n 266.
} 


\section{G Retirement Villages}

The study initially intended to include an assessment of retirement villages as a type of multi-unit buildings. However, the thesis no longer examines retirement villages for two reasons.

First, by and large, retirement villages do not fit within the notion of a multi-unit building proposed by the thesis. In New Zealand, the most common form of retirement village tenure is a licence to occupy. ${ }^{268}$ This is generally drafted as an occupation right agreement between a purchaser (who becomes a "resident") and the operator. The resident obtains no interest in the underlying land and has limited rights in relation to the unit itself. The operator is the one who owns the units and has an obligation to maintain them. There is no repair dependency in this situation. The units are all owned by the same operator (so repairs would not impact on a different owner, although they would impact on different occupiers) and the operator makes all the decisions, including who to insure the property with, and how the insurance claim is resolved. There is no decision dependency either. They might look similar to company share scheme (in that a company holds the ownership to the land and the buildings) but they are quite different. Retirement village occupiers might have a say in relation to the interior of their unit, but have little or no say in relation to the overall building and cannot impose directions on the owner company through voting. Most of the time there are limitations on the sale of the unit, and the occupier does not benefit from the capital gains made on their unit or even recover the amount they have paid for the unit if they decide to sell. ${ }^{269}$

There are some retirement villages that are organised as Body Corporates and where the residents own their units. ${ }^{270}$ The Body Corporate would arrange insurance for the building. This is no different than a Body Corporate situation already covered in the thesis.

\footnotetext{
${ }^{268}$ Village Guide "What is a licence to occupy?" accessed 25 April $2020<$ www.villageguide.co.nz>.

269 Law Link "Retirement village living: Pros and cons" (online ed, undated) <www.lawlink.co.nz/article/retirement-village-living-pros-cons/>; Money Hub "Retirement Villages (online ed, 23 December 2019) <www.moneyhub.co.nz/retirement-villages.html>.

${ }^{270}$ Toomey Finn research paper, above n 26 at 285.
} 
Second, interviews with members of the insurance industry did not reveal any special issues in relation to resolving claims for retirement villages. The only difficulty that was mentioned was that resolving claims for retirement villages requires significant technical expertise. ${ }^{271}$ Retirement villages are usually large complexes with a core central building and many adjunct buildings and outbuildings. This makes it difficult to determine the extent of damage to the complex as a whole.

There is one notable observation that is worth mentioning here. Before the Canterbury earthquakes, if a unit in a retirement village had been damaged in a way that it could no longer be occupied, and it was not the operator's fault, the licence to occupy became inoperative. There was no obligation on the operator to compensate the resident or continue to offer the unit. This is interesting because the operator would have had insurance for damage to the units. In addition, some operators were able to receive compensation from the government as part of the red zone buyout programme for damaged land. ${ }^{272}$ That meant it was open for the operators to terminate the contracts with their residents, use the insurance money to rebuild the units, and then sell the licences to new residents. In Christchurch, there were no reports of operators terminating the contracts with the residents; instead it appears that the affected retirement village operators tried their best to look after their residents and find alternative accommodation for the residents in the operator's other retirement villages. ${ }^{273}$

On 14 October 2013, the Retirement Villages Code of Practice 2008 was amended to say that operators should take steps to repair or replace the damaged unit as quickly as possible and at the very least consult with the resident over the reinstatement. If it is not possible to

\footnotetext{
${ }^{271}$ Interview with IAG New Zealand.

272 In 2015, following the Canterbury earthquakes, the government through its appointed agency CERA announced an offer to purchase approximately 7,500 properties that were red zoned (ie had significant land damage). The offer was to be based on the 2007/2008 rateable valuation of the land and CERA was to recoup some of the cost by making claims against EQC for the land damage. A large proportion of owners accepted the Crown offer. CERA was created by the Canterbury Earthquake Recovery Act 2011.

273 Toomey Finn research paper, above n 26 at 282.
} 
reinstate, clause $47(2)(e)$ says that that retirement village residents will be entitled, as a minimum, to receive the full original capital sum of their investment in a retirement village in a "no fault termination". ${ }^{274}$ There are suggestions that the current legislation does not fully protect retirement village residents in cases of major damage; ${ }^{275}$ however, these concerns relate to property law and social protection measures that are outside the scope of the thesis.

\section{H Conclusion}

Increased population, coupled with the increased cost of ownership has forced division of property into smaller parts, or units, that are more affordable. If there is one certainty, it is that the number of multi-unit buildings is growing.

The historical evolution of the various property titles that cater for multi-unit buildings show a swing of approaches to owner autonomy. Company share schemes and unit titles restrict owner autonomy. The community of owners is subject to a governance structure, and decisions are made through voting. Owners are subject to the majority rule. Units are insured together. By contrast, cross-leases and fee simple townhouses swing the pendulum to the other end of the spectrum in a desire to maximise owner autonomy. In general, they do not have a governance structure, and each owner makes decisions independent of the others. Units are generally insured on an individual basis.

Insurance provides specific products to cater for some of these titles, including specialist policies designed for Body Corporates and company share schemes. The next chapter explores the insurance arrangements generally available in New Zealand for multi-unit buildings.

\footnotetext{
274 Retirement Villages Code of Practice, cl 47.

275 Toomey Finn research paper, above n 26 at 295.
} 


\section{THE INSURANCE CONTEXT}

This chapter introduces the reader to the insurance market in New Zealand, the insurance policies available for multi-unit buildings, and the extent of their cover and limitations. It provides the background for the discussion in the chapters that follow. The chapter also briefly engages with some of the theoretical questions related to the nature and principles of insurance law and the modalities of this form of private ordering. ${ }^{276}$

Treasury reports that by international standards New Zealand homeowners carry high rates of house insurance. ${ }^{277}$ This is good because insurance plays an important social and economic function and contributes to community resilience. It frees owners to use their funds for useful purposes and assists in a recovery following a natural disaster. ${ }^{278}$

Insurance has developed as a result of humans' aversion to risk. Most people choose to offload anxiety by transferring the risk to someone else. ${ }^{279}$ This has been termed the "purchase of peace of mind". 280

\footnotetext{
${ }^{276}$ See generally John Lowry and Philip Rawlings Insurance Law Doctrines and Principles (2nd ed, Hart Publishing, Oregon, 2005); Robert Merkin Insurance Law - An Introduction (Informa, London, 2007); John Birds Birds' Modern Insurance Law (8th ed, Sweet \& Maxwell, London, 2010); ER Hardy Ivamy General principles of Insurance Law (6th ed, Butterworths, London, 1993); Robert Merkin and Raoul Collinvaux Collinvaux's Law of Insurance (8th ed, Sweet \& Maxwell, London, 2006).

277 Treasury New Zealand's Future Natural Disaster Scheme: Proposed Changes to the Earthquake Commission Act 1993 (online ed, 5 July 2015) <www.treasury.govt.nz> at 1.

${ }^{278}$ Silvia Cartwright Public Inquiry into the Earthquake Commission (ISBN 978-0-947520-25-0, 31 March 2020) <www.eqcinquiry.govt.nz> at 47.

279 Malcolm Clarke Policies and Perceptions of Insurance Law in the Twenty-First Century (Oxford University Press, Oxford, 2005) at 3.

${ }^{280}$ Clarke, above n 279 at 3.
} 


\section{A What Is Insurance?}

Section 7 of the Insurance (Prudential Supervision) Act 2010 defines a contract of insurance as:

[A] contract involving the transference of risk and under which a person (the insurer) agrees, in return for a premium, to pay to or for the account of another person (the policyholder) a sum of money or its equivalent, whether by way of indemnity or otherwise, on the happening of 1 or more uncertain events;

uncertain event means an event-

(a) with respect to which there is (from the perspective of the policyholder) an element of uncertainty as to when or whether it will take place; and

(b) that is beyond the insurer's control.

An insurance contract therefore must involve the transfer of a risk (a fortuity) in exchange for money (premium). The contract involves an obligation to pay or indemnify the insured (policyholder) on the happening of the uncertain event insured against (contingency). Insurance "is a contract based upon speculation". 281

The insurance contract (called policy) imposes obligations on the policyholder in relation to the conduct of the claim. For example, a policyholder must cooperate and provide the insurer with the information relevant to the claim. The policyholder must obtain the insurer's permission before incurring costs. ${ }^{282}$

The insurer has the right to be involved in determining the extent of loss, the quantum, and sometimes the way to resolve the claim. This means the insurer becomes a decision-maker. The owner retains certain decision-making powers. But insurers might also need to liaise and agree with the insurer next door, if the repair dependencies are engaged and there are other insurers on risk. The need for insurers to work together brings a second overlay of

\footnotetext{
${ }^{281}$ Carter v Boehm (1766) 3 Burr 1905 at 1910.

${ }^{282}$ Except the reasonable cost of doing urgent work to prevent further loss.
} 
decision-making powers. During an insurance claim there will be a double decision dependency if there are multiple insurers in a development.

The insurer calculates the risk before accepting it. This is called underwriting. The underwriting process involves an assessment of the potential risks, the level of coverage the insurer is prepared to offer, any specific exclusions the insurer wants to impose (in other words, the risks the insurer is not prepared to take), and the price (premium) to be paid in exchange for the risk. Insurance policies do not cover all risks; there are always exclusions and limitations.

There is no general obligation on an insurer to offer cover. ${ }^{283}$ Insurance is not a guaranteed right. And when it is offered, the premium reflects the underwriter's assessment of the risk. If the underwriter believes the risk of damage is high, or the risk of a large claim is high, the premium can become significant. There were concerns following the Canterbury earthquakes that the insurance premiums for Body Corporates increased to the point of being unaffordable. ${ }^{284}$ This is significant as higher premiums can lead Body Corporates to intentionally underinsure.

Insurance contracts generally run for a year, then renew. Insurance is not a "set and forget" contract but requires a renewed assessment of risk and needs each year. This is important particularly in the context of a Sum Insured policy. If owners do not keep up with their annual assessment of costs, they might find themselves underinsured.

A policyholder is responsible for paying the first part of the loss. This is called the excess. The reason behind imposing a policy excess is to reduce the number of small claims, ${ }^{285}$ and "to give policyholders some 'skin in the game', to encourage them to take care". ${ }^{286}$ The excess is a form of self-insurance. ${ }^{287}$ The amount of the excess can differ from insurer to

\footnotetext{
${ }^{283}$ Clarke, above n 279 at 88.

${ }^{284}$ Toomey Finn research paper, above n 26 at 209-210; Interview with Greenwood Roche.

${ }^{285}$ Which raises the insurers' operating costs leading to an increase in premiums.

${ }^{286}$ Rob Stock “Why Do Insurance Customers Have to Pay Excess?” Stuff (online ed, 4 April 2018).

${ }^{287}$ Stock, above n 286.
} 
insurer. Sometimes there are different excesses for different risks under the same policy. For example, following the Canterbury earthquakes, insurers have imposed an increased excess for claims arising out of natural disasters, sometimes ten times higher than the standard excess.

Insurers insure themselves against large risks. This is called reinsurance. Reinsurance is often necessary to help insurance companies meet their statutory solvency requirements. In New Zealand, insurers are subject to prudential regulation by the Reserve Bank, which requires insurers to keep enough cash reserves or to have sufficient reinsurance to be able to meet claims to a specific threshold. That threshold is very high in New Zealand compared to the rest of the world. ${ }^{288}$

Reinsurance was crucial to support insurance companies during the Canterbury earthquakes. One insurance company that had inadequate reinsurance had to be bailed out by the government because it did not have sufficient money to meet all the claims. ${ }^{289}$

\section{B Principles Applicable to Insurance Contracts}

Insurance law is part of the general law of contract. ${ }^{290}$ However, insurance contracts are governed by a few principles of their own. I briefly mention three principles here that are relevant to the thesis.

\footnotetext{
${ }^{288}$ ICNZ website <www.icnz.org.nz/industry-leadership/regulation/>.

${ }^{289}$ Marta Steeman “Quake-hit AMI Insurance bailout could cost \$1billion” Stuff (online ed, 7 April 2011). The government took over the failed insurance company and split it in two. The part of the business responsible for paying the earthquake claims was renamed Southern Response and became a government entity. The rest of the business was sold to IAG New Zealand, and it continues to trade under the name AMI Insurance.

${ }^{290}$ Robert Merkin and Chris Nicholl (eds) Colinvaux's Law of Insurance in New Zealand (2nd ed, Thomson Reuters, Wellington, 2017) at 3; Molyneux Holdings v IAG New Zealand [2007] NZCA 254 at [22]; Little v IAG New Zealand (2010) 16 ANZ Insurance Cases 61-860 at [11].
} 


\section{Duty to disclose material facts}

Policyholders have a duty to disclose to the insurer all material facts related to the property that is to be insured. The duty of disclosure arises out of the doctrine of the utmost good faith. $^{291}$

Disclosure of material facts is essential for good underwriting. Relevant to the thesis is disclosure about repair dependencies. It is important for insurance companies to know the type of building they insure, whether it is standalone or has shared construction elements. Sometimes property developers, perhaps for marketing reasons, number fee simple townhouses in the same way as standalone properties (for example, 22, 24, 26) rather than the conventional way of numbering units in a development (for example, 22A, 22B, 22C). A policyholder providing the address of the property (say 22 Kent Street) will not alert the insurer to the fact that the property is part of a multi-unit building. In Chapter V, I suggest that insurers ask additional questions when they sell a policy in order to determine exactly whether or not a property is a multi-unit building. But the starting point is that the owner has a duty to disclose all material facts to the insurer in the first place.

\section{The Wayne Tank principle}

Insurance policies exclude certain type of damage. Where there are two or more concurrent causes of a loss, one of which is insured and the other excluded, then the entire claim is excluded. This is known as the Wayne Tank principle. ${ }^{292}$

\footnotetext{
${ }^{291}$ For more information on the doctrine of utmost good faith, see Carter v Boehm (1766) 3 Burr 1905; Merkin and Nicholl, above n 290 at 164; Lindsay Lloyd and Paul Michalik "Insurance Law - a practical guide" (NZLS seminar, 2012).

292 Wayne Tank and Pump Co v Employers Liability Assurance Corporation [1974] 1 QB 57 (CA). Its application in New Zealand has been confirmed in AMI Insurance v Legg [2017] NZCA 321, [2017] 3 NZLR 629 at [46].
} 
This is relevant in the context of home and material damage policies where the property has pre-existent damage (excluded) and then suffers accidental physical damage (which is insured). I give examples ${ }^{293}$ and discuss this further in Chapters IV and V where I examine delays caused to claims where there was pre-existing damage.

\section{The principle of indemnity}

Running like a red line through an insurance contract is the principle of indemnity. This means a policyholder is entitled to be put back in the position they were in prior to the loss but no better: 294

A contract of insurance is necessarily a contract of indemnity (except life and personal accident insurance) and of indemnity only, and this means that in case of a loss the insured shall be fully indemnified, but shall never be more than fully indemnified.

Over the years, there have been some departures from the strict application of the principle of indemnity. The most notable and also of special relevance to the thesis is Full Replacement policies for residential homes. These policies offer cover on a new-for-old basis, therefore indemnifying the policyholders beyond the value of that they have lost. This extended cover is subject to conditions as detailed further in the thesis.

\section{The Insurance Contract}

There are many ways of classifying insurance contracts according to the nature of the interest affected. ${ }^{295}$ One way to classify them is into personal, property, and liability insurance contracts. The thesis is concerned with property insurance, and in particular with

\footnotetext{
${ }^{293}$ Sadat $v$ Tower Insurance \& EQC [2017] NZHC 1550.

${ }^{294}$ Castellain v Preston (1883) 11 QBD 380 (CA).

${ }^{295}$ AA Tarr and JA Kennedy Insurance Law in New Zealand (2nd ed, The Law Book Company, Sydney, 1992) at 12.
} 
contracts of house insurance and material damage insurance. These are also known as fire insurance. ${ }^{296}$

The wordings are generic contracts, not tailor-made. There is no standard wording across the insurance industry. Each insurance company has its own wording. Further, almost every insurance company has more than one wording. ${ }^{297}$ There are differences between the wordings although the standard benefits are similar.

Following the Canterbury earthquakes, there were calls to consolidate policy wordings or make them more uniform between insurers so that there was less debate over their interpretation. ${ }^{298}$

Such suggestions were not followed as insurers generally wanted to retain their customised offering. However, as detailed below, there are a number of similarities between the various policy wordings and there is already a level of standardisation in property insurance policies.

Fee simple townhouses and cross-lease properties are generally insured under a residential house insurance policy. Body Corporates and company share schemes are treated as commercial entities and are insured under a material damage (MD) policy. Both types of policies (residential house policies and commercial MD policies) provide cover against material damage to the building, but some terms can differ, as detailed later in the chapter. $^{299}$

\footnotetext{
${ }^{296}$ Property insurance was initially developed mainly as insurance against risk of fire, its growth triggered by the Great Fire of London in 1666. See Tarr and Kennedy, above $n 295$ at 3.

${ }^{297}$ For example, a search of the domestic insurer Tower's website shows five available products: Premium House, Plus House, Standard House, Landlord's Plus House, Sum Insured House Insurance <www.tower.co.nz>.

${ }^{298}$ Henry Holderness "Replacement Cover in Residential Property Insurance and the Canterbury Earthquakes 2010-2011" (2017) 23 NZBLQ 3.

${ }^{299}$ They provide cover for other risks as well, but I am only detailing the terms relevant to the thesis.
} 
MD policies are generally intermediated by an insurance broker. Brokers can sometimes negotiate bespoke policy terms called agreed broker wordings. This is different from consumer insurance where homeowners arrange their own insurance. In those cases, insurers provide a standard form policy that cannot be changed, although a customer can choose between the different wordings available from the same insurer ${ }^{300}$ or can shop around for better terms with another insurer.

Insurance contracts have been described as the archetype of contracts of adhesion, tantamount to private or delegated legislation. ${ }^{301}$ An insurance policy has a significant number of boilerplate provisions. However, this is not in itself problematic. Standardisation "may well facilitate commercial transactions because everybody knows how courts would interpret the clauses in such contract". 302

The reality is that there is little scope for a homeowner to negotiate the terms. Even with agreed broker wordings the insurer would not generally agree variations from contract to contract. If the broker has negotiated an agreed wording to apply, say, to its Body Corporate clients, then all the broker's Body Corporate clients would be offered the same agreed wording. While this may look like it is taking away a policyholder's freedom to negotiate terms, it is necessary for the functioning of an insurance company. The more variations in its wordings, the more work and internal training required for the staff who sell the policies or apply the terms at claim time. This is only going to lead to an increased operational cost and therefore increased premiums. Bespoke terms, if they are necessary, can be dealt with by way of endorsements on the policyholder's policy schedule.

\footnotetext{
${ }^{300}$ Insurers would usually have a range of policies providing from basic terms to more comprehensive cover depending on price.

301 Margaret Jane Radin Boilerplate: The Fine Print, Vanishing Rights and the Rule of Law (Princeton University Press, eBook, JSTOR Ebook, 2013) at 42.

302 Radin, above n 301 at 42.
} 


\section{The Basics of a Residential Home Policy}

A domestic home policy provides indemnity against loss to the home that happens during the period of insurance.

"Home" is defined first by reference to the address of the property stated in the policy schedule, including its size in square metres. The policy provides a further description of what it includes in the term "home". The definition includes the buildings and outbuildings at the insured address, decks, patios, driveways or private roads, fences, septic tanks, swimming pools, drains, and pipes.

The definition of "home" contains some very important carveouts such as the land upon which the house sits, any earth or fill, temporary structures, trees and plants, boat ramps, cable cars, culverts, bridges, and others. One must check the exact policy definition to determine what is insured. The fact that insurers do not insure land was significant in Canterbury where there was extensive land damage.

"Loss" is usually defined as "sudden, unforeseen, accidental physical loss or sudden, unforeseen, accidental physical damage"; 303 or accidental "physical loss or physical damage". ${ }^{304}$ Other policies use slightly different wording but with similar meanings. For example, Tower's House Maxi Protection policy says cover is provided for "sudden and accidental physical loss or sudden and accidental physical damage happening during the period of insurance, unless excluded". 305

Three requirements emerge from the definitions above. The first is that the loss or damage must be sudden. Wear and tear or gradual damage is excluded. ${ }^{306}$ In Sadat $v$ Tower

\footnotetext{
303 AA Insurance Home insurance policy wording version AAI_HHOME_V2_1608 <www.aainsurance.co.nz/documents/policy-documents/home-insurance-policy.pdf>

304 State Home Comprehensive policy wording, version SI1048/5 11/14, found online <www.state.co.nz/PDFs/State_Home_Comprehensive_PW-11-14.pdf>.

305 Tower House Maxi Protection policy wording version P08 05-13 <www.tower.co.nz>

306 There is some limited cover being offered for hidden gradual damage caused by leaking internal pipes.
} 
Insurance $e^{307}$ the Sadats claimed that the house required rebuilding following the 4 September 2010 earthquake. The Court found that the damage was due to gradual deterioration caused by subsidence prior to the earthquake, and that to remedy that damage was no different than what would have been required to remedy all the pre-existing problems. ${ }^{308}$ Insurance does not cover gradual deterioration. However, that does not mean that insurers are not concerned about properties that are being left in a state of disrepair. Lack of maintenance can create conditions for property damage, which then raises the question whether the damage was truly fortuitous.

The second requirement is for the damage to be accidental. The word accidental is often accompanied by words such as unexpected or unintended or unforeseen. This ties in with the underlying principle that insurance is a contract upon speculation and must involve a fortuity. Intentional damage caused by the policyholder or someone else who is in the house with the policyholder's permission is not covered. More contentious are cases where there is pre-existing damage to the property. In those cases, sometimes it is foreseeable and expected that if an event happens, it will cause damage to the property. For example, if a roof is in a poor state, it is foreseeable that a storm will damage it. ${ }^{309}$ The issue of preexisting defects has featured in some of the Canterbury earthquake claims. This issue will be discussed in Chapter IV in the context of Body Corporate claims that had pre-existing weathertightness issues that required extensive repair work. The requirement for accidental damage is also important when owners need to assess the cost responsibility for collateral damage. If unit $\mathrm{B}$ is damaged as a result of repairs carried out for unit $\mathrm{A}$, is the damage to unit B truly accidental? And if not, who has the responsibility of paying for it? I discuss this in more detail in Chapter V.

The third requirement is for the loss or damage to be physical. Something tangible must be lost or damaged. Temporary deprivation of possession is not sufficient. ${ }^{310}$

\footnotetext{
307 Sadat v Tower Insurance, above n 293.

${ }^{308}$ Sadat v Tower Insurance, above n 293 at [255].

${ }^{309}$ IFSO complaint 117137 which settled with the insurer paying only a share of the cost to replace the roof.

${ }^{310}$ Kraal v EQC [2015] NZCA 13, [2015] 2 NZLR 589.
} 
The exclusions and limitations reinforce that insurance policies are not a catch-all safety net. There are losses that fall outside the scope of an insurance policy.

\section{E Types of Residential Home Policies}

According to ICNZ ${ }^{311}$ there are three different types of house policies available: ${ }^{312}$ Total Replacement, Specified Sum Insured, and Indemnity policies. ICNZ reports that most houses in New Zealand are insured under replacement cover policies, ${ }^{313}$ which are of two types: Full Replacement and Specified Sum Insured.

\section{$1 \quad$ Full Replacement policies}

Full Replacement policies provide cover on a new-for-old basis and have no monetary limit. However, they are limited by the square metre area of the property as declared by the policyholder in the proposal. ${ }^{314}$

Most of the policies in force at the time of the Canterbury earthquakes were Full Replacement policies. As already mentioned, they are a departure from the principle of indemnity, and the High Court pointed out that the indemnity principle is "a slightly awkward phrase in the context of a replacement policy". ${ }^{315}$ As described by the Supreme

\footnotetext{
${ }^{311}$ ICNZ was established in 1895 and is the representative body of the general insurance industry in New Zealand.

${ }^{312}$ ICNZ <www.icnz.org.nz>.

${ }^{313}$ ICNZ "Replacement vs Indemnity insurance" 〈www.icnz.org.nz>.

${ }^{314}$ This principle was upheld in Myall v Tower Insurance [2017] NZHC 251 where the Court confirmed that an insurer can apply a pro rata approach in assessing the replacement cost of a house to reflect that it was underinsured. In that case, the house was insured on the basis that it was 650 sqm but it was in fact 799 sqm. But see Sadat v Tower Insurance, above n 293 for a refinement of that principle.

${ }^{315}$ Tower Insurance v Skyward Aviation 2008 [2014] NZSC 185 at [25], [2015] 1 NZLR 341 citing Ridgecrest $v$ IAG New Zealand [2014] NZSC 129 at [54], [2015] 1 NZLR 40.
} 
Court, these policies proceed on the basis of providing new for old, covering the impact of depreciation and rising building costs. ${ }^{316}$

The precise application of a replacement policy differs according to each wording. Given the large number of wordings available on the market, it is not possible to interpret them all here. I have decided to use the wording subject to a court decision in Turvey Trustee $v$ Southern Response ${ }^{317}$ which is fairly representative of a Full Replacement policy. The relevant clauses read:

\section{What we will pay}

a. We will pay to repair or rebuild your house to an 'as new' condition, up to the floor area stated in the Policy Schedule.

b. We will use building materials and construction methods in common use at the time of repair or rebuilding.

c. If your house is damaged beyond economic repair you can choose any one of the following options:

i to rebuild on the same site. We will pay the Full Replacement cost of rebuilding your house.

ii to rebuild on another site. We will pay the Full Replacement cost of rebuilding your house on another site you choose. This cost must not be greater than rebuilding your house on its present site.

iii to buy another house. We will pay the cost of buying another house, including necessary legal and associated fees. This cost must not be greater than rebuilding your house on its present site.

iv a cash payment. We will pay the market value of your house at the time of the loss.

We will pay for the following additional costs

\section{Compliance with building legislation and regulations}

\footnotetext{
316 Tower Insurance v Skyward Aviation 2008, above n 315 at [24].

317 Turvey Trustee v Southern Response [2012] NZHC 3344, [2013] 17 ANZ Insurance Cases 61-965.
} 
a. If additional work is required, we will pay the reasonable costs for compliance with building legislation and rules.

b. However, we will not cover the additional work required if:

i a notice has been served requiring compliance with the Building Act 1991 or the Resource Management Act 1991 before the loss or damage occurred, or ii your house did not comply with the relevant governing building controls when it was built or at the time of any alteration.

There were additional clauses in the policy promising to pay the costs of demolition and debris removal, and also for removal of household contents when that was necessary to carry out repair or reinstatement.

If a property is partially damaged and can be repaired, the policy promises to pay the cost of repair.

Once a property is damaged beyond economic repair, there is a choice on how the claim is settled. Sometimes the choice rests with the policyholder and other times the choice rests with the insurer, depending on the exact terms of the policy wording. The wording above gives the choice to the policyholder.

The wording above is also quite generous in the choices it provides. There are four choices open to the policyholder: (1) actual rebuild costs; (2) rebuild costs to build on another site; (3) the cost to buy a similar property; or (4) cash in hand for the market value of the property.

Some policy wordings do not offer the choice to purchase another property or to rebuild on a different site. The two basic choices are repair or rebuild costs (if these are incurred), or a cash settlement based on the indemnity value of the property (if the property is not repaired or rebuilt). If the house is not going to be rebuilt on the same site, the costs are to be quantified by reference to the cost that would have been incurred to rebuild the house 
on the existing site, including an allowance for contingency and professional fees. ${ }^{318}$ However, if the costs to rebuild on the existing site are higher, for example due to damage to the land, but these costs are not going to be incurred on the new site, the policyholder is not entitled to claim the costs that are not going to be incurred on the new site as that would constitute a windfall. ${ }^{319}$

An insurance policy does not cover land so when the policy talks about indemnity value, it refers to the value of the buildings only.

A replacement home policy will often cover the professional fees that need to be incurred in order to proceed with the repairs or the rebuild. This would include the cost of an architect, structural engineer, surveyor, geotech engineer, and so on, and contingencies. The cost of demolition and removal of debris is also covered. This is a valuable benefit as professional fees and demolition costs can be significant.

There is additional cover for compliance costs. This is important. For example, during the Canterbury earthquakes insurers paid earthquake-strengthening costs for Body Corporates if these were necessary to comply with the Building Code. ${ }^{320}$

\section{Reinstatement obligation}

While the general obligation is "to pay", insurers sometimes stipulate an alternative to provide indemnity by repair or replacement. Insurers reserve this option to limit moral hazard. ${ }^{321}$ Replacement policies make reinstatement costs conditional on the actual

\footnotetext{
${ }^{318}$ Avonside Holdings v Southern Response [2014] NZCA 483 at [58], (2014) 18 ANZ Insurance Cases $62-$ 040 .

${ }^{319}$ Turvey Trustee $v$ Southern Response, above n 317.

${ }^{320}$ Insurance Council of New Zealand v Christchurch City Council, [2013] NZHC 51 at [4], 17 ANZ Insurance Cases 61-956. The issue in that case was whether the insurers were liable to pay for costs to comply with a more stringent policy issued by Christchurch City Council.

${ }^{321}$ Prattley Enterprises v Vero Insurance [2016] NZSC 158, [2017] 1 NZLR 352.
} 
reinstatement. That is, the insurer is not obliged to pay the reinstatement costs until the costs have been incurred or committed to being incurred. ${ }^{322}$

The insurer has the right to pay the cash equivalent of the repair costs or, if the house needs to be rebuilt, of the rebuild costs. The obligation as stated in the policy is generally "to pay":323

The obligation of an insurer at common law is to pay to the assured the sum agreed or a sum representing their loss, depending on whether the policy is valued or unvalued. Consequently, it is not open to an insurer, or for that matter the assured, to insist upon reinstatement in the absence of a reinstatement clause. Nevertheless, it has been common for centuries to find in property policies, particularly policies on buildings, a clause conferring upon the insurer the option either to pay to the insured the sum agreed under the policy, or to reinstate or repair the subject-matter in question. More recently, policies have conferred an option to the assured to elect between reinstatement or payment of an indemnity.

The insurer is not obliged to get involved with or to manage the repair process. I will touch on this point again in Chapter V where I discuss the implications of cash settlements. Sometimes, cash settlements are undesirable, and it would be good to have the insurer involved in the reinstatement. However, insurers cannot be forced to be involved in the reinstatement as their obligation is "to pay".

Sometimes the insurer wants to be involved because it can control costs by managing the process or obtaining discounts from its trade suppliers. Because of its buying power, an insurer can often negotiate better terms for labour and materials.

\footnotetext{
${ }^{322}$ Medical Assurance Society v East [2015] NZCA 250 at [21] and [27], [2015] 18 ANZ Insurance Cases 62-074

${ }^{323}$ Robert Merkin and Chris Nicholl (eds) Colinvaux's Law of Insurance in New Zealand (Thompson Reuters, Wellington, 2014) at 540.
} 
Policies will stipulate who has the right to make the election on how the claim is going to be resolved (via a cash payment or by repairs). However, both the insurer and the policyholder will be involved to a certain degree in making decisions. This affects how the decision dependency is exercised because the insurer and the policyholder will need to consult with each other, and then with the others in the development.

\section{The standard of reinstatement}

The standard of repair in a Full Replacement policy is new-for-old. This clause is of crucial importance in a policy because it describes the extent of the policy benefit. The words used to describe the reinstatement standard differ between policy wordings but some of the most common expressions are: "a condition as similar as possible to when it was new, using current industry accepted building materials and construction methods"; 324 or a "building standard and specification similar to, but no more extensive or better than the condition of, your home when it was new or last enhanced, using currently equivalent techniques and building materials readily available in New Zealand; ${ }^{325}$ or "“as new' condition, up to the floor area stated in the Policy Schedule [using] building materials and construction methods in common use at the time of repair or rebuilding". 326

In Medical Assurance Society v East, the Court of Appeal decided that "in ordinary language the phrase 'as new' where used to require the rebuilt or restored condition of the house is a quality standard, not a temporal standard". ${ }^{327}$ In Turvey Trustee the "as new" standard was interpreted as requiring equivalence rather than replication. ${ }^{328}$ In Fitzgerald $v$ IAG New Zealand the Court confirmed that there is a difference between a benefit described by the words "as new" as opposed to "when new". 329

\footnotetext{
${ }^{324}$ State Home Comprehensive Insurance policy wording version SI1048/8 <www.state.co.nz/PDFs/State_Home_Comprehensive_PW.pdf>.

325 AA Insurance Home insurance policy wording version AAI_HHOME_V2_1608 <www.aainsurance.co.nz/documents/policy-documents/home-insurance-policy.pdf>.

326 The Southern Response policy wording applicable in the case of Turvey Trustee v Southern Response, above n 317.

${ }^{327}$ Medical Assurance Society v East, above n 322.

${ }^{328}$ Turvey Trustee $v$ Southern Response, above n 317.

${ }^{329}$ Fitzgerald v IAG New Zealand [2018] NZHC 3447 at [28].
} 
As seen from the cases cited, a large number of disputes arising out of the Canterbury earthquakes related to disagreements about the standard of reinstatement. The majority were not multi-unit building claims, but the case law clarified the way to interpret the policies, so they assisted in resolving claims for multi-unit buildings too. ${ }^{330}$

\section{Specified Sum Insured policies}

Since the Canterbury earthquakes, most insurers in New Zealand have removed the offer of Full Replacement policies and started offering Specified Sum Insurance policies. These policies promise to pay to replace an insured item on a new-for-old basis unless the cost exceeds the specified amount (the Sum Insured) in which case the Sum Insured is paid. ${ }^{331}$

The phrase Sum Insured "does not amount to an agreed valuation but merely fixes the maximum sum for which the insurer can be liable."332 The insurer's obligation is therefore

\footnotetext{
${ }^{330}$ For example, Medical Assurance Society v East, above n 322; Turvey Trustee v Southern Response, above n 317 and Myall v Tower Insurance, above n 314 clarified the standard of reinstatement applicable in insurance policies; Jarden v Lumley General Insurance (NZ) Ltd [2016] NZCA 193, (2016) 19 ANZ Insurance Cases 62-104 decided that private insurers had no obligation to pay for natural disaster damage until EQC's obligations under the Act have been established; Sadat v Tower Insurance, above n 293 clarified that where there was pre-existing damage (excluded from cover) followed by earthquake damage, the insurer had no obligation to pay; Avonside Holdings v Southern Response, above n 318 clarified what insurers have to allow for when assessing quantum; Xu v IAG New Zealand [2019] NZSC 68, [2019] 1 NZLR 600 clarified what can be claimed under an assigned insurance claim; Earthquake Commission v Insurance Council of New Zealand [2014] NZHC 3138, [2015] 2 NZLR 381 decided that increased flooding or liquefaction vulnerability constitutes natural damage and clarified EQC's obligations; QBE Insurance $v$ Wild South Holdings [2014] NZCA 447, [2015] 2 NZLR 24 and Marriott $v$ Vero Insurance [2013] NZHC 3120 clarified how to determine whether a building is totally destroyed when the building has been damaged incrementally in successive events; how to calculate entitlement for each event, and how to apply the policy excess; Ridgecrest $v$ IAG New Zealand, above n 315 considered whether a policyholder is entitled to the aggregate value of multiple losses during the period of insurance; Tower Insurance v Skyward Aviation 2008, above n 315 considered proposals for novel repair methods; TJK (NZ) v Mitsui Sumitomo Insurance [2013] NZHC 298, 17 ANZ Insurance Cases 61-968 held that insurers were required to pay the indemnity value costs prior to reinstatement; Re Earthquake Commission [2011] 3 NZLR 695 decided that where losses occur in succession, EQC's liability is per event even when the damage has not been repaired between losses.

${ }^{331}$ Insurance Council of New Zealand 〈www.icnz.org.nz〉.

${ }^{332}$ Merkin and Nicholl, above n 290 at 538.
} 
to pay the actual loss up to the Sum Insured, not to automatically pay the Sum Insured. If an owner sets the Sum Insured to say $\$ 1,000,000$ but the cost to rebuild is in fact $\$ 800,000$, the insurer will pay only $\$ 800,000$. This is a straight application of the principle of indemnity (policyholders cannot be more than indemnified for their loss) and an anti-fraud device to avoid temptation to bring about a claim.

Sum Insured policies have been in and out of favour in New Zealand for some time. It appears they were introduced in New Zealand by the early 1950s, and certainly by the 1970s. ${ }^{333}$ However, by the time of the Canterbury earthquakes they were almost completely overtaken by Full Replacement policies.

The size and extent of the Canterbury earthquakes put into question the viability of the Full Replacement offering in New Zealand. The open-ended liability of insurers could not be sustained at prices that were reasonable in New Zealand. New Zealand insurers struggled to find affordable reinsurance. ${ }^{334}$

In 2013, most insurers ceased offering Full Replacement policies and reintroduced Sum Insured policies. At the time, ICNZ issued an announcement to say that these changes occurred as a result of the Canterbury earthquakes and that they would bring New Zealand in line with the rest of the world. ICNZ cautioned that the global reinsurers were only prepared to continue to offer reinsurance if they knew the costs they were going to face. The move to Sum Insured gave them that. ICNZ further explained that higher levels of certainty meant that insurance for New Zealanders would remain as affordable as possible. ${ }^{335}$

\footnotetext{
${ }^{333}$ Holderness, above n 298.

${ }^{334}$ Insurance Council of New Zealand <www.icnz.org.nz〉.

${ }^{335}$ Insurance Council of New Zealand <www.icnz.org.nz〉.
} 
In the years that followed, insurance companies have started to soften their position. Some started offering limited Full Replacement cover for risks other than natural disasters. The offering in this area is still in a matter of flux. ${ }^{336}$

Sum Insured policies, sometimes called Agreed Value policies, operate in a similar manner to Full Replacement policies but restrict cover to the Sum Insured specified in the schedule. The limit includes the Compliance Costs, Professional Fees, Demolition, and Debris benefits.

Provided the Sum Insured is adequately set, there should be no difference between a Full Replacement Policy and a Sum Insured policy. The standard of reinstatement (that crucial clause discussed above) is still replacement, that is, new-for-old. Problems arise where there is underinsurance. It is therefore important for policyholders to set the Sum Insured as accurately as possible.

\section{The Cordell calculator}

At the moment, homeowners can use the Cordell calculator to help them set the Sum Insured. Cordell is an online calculator provided by an independent company, available free of charge on insurance companies' websites. It calculates the Sum Insured based on parameters being imputed, including location of the property, type of construction, size of the property, number of bedrooms and bathrooms, additional facilities such as tennis courts or swimming pools, quality of construction, number and size of retaining walls and driveways, and other factors.

I tested the Cordell calculator against a real example to see how accurate it is. I took the house at the centre of a court case between Sadat and Tower Insurance because the size, description of the house, and full rebuild costs were provided in a Court judgment. ${ }^{337}$ The

\footnotetext{
${ }^{336}$ At the moment, Farmers Mutual Group (FMG) and Medical Assurance Society offer Total Replacement policies subject to conditions. Some other insurers offer limited replacement cover if the loss is not caused by a natural disaster or for some specific events such as fire.

${ }^{337}$ Sadat v Tower Insurance, above n 293.
} 
Sadats owned a house at 3 Victors Road in Hoon Bay, Christchurch. The house was a brick house with corrugated iron roof, noted as 120sqm but in fact found to be 141 sqm by the court, ${ }^{338}$ so I used 141 sqm as the true measure. The property sold in 2018 , so there were marketing photos available on the internet. It had a double garage but no other outbuildings. The judgment says that a qualified quantify surveyor estimated the replacement cost at $\$ 762,000$ including GST. Tower Insurance challenged the assessment. The Court found that the replacement cost would have been $\$ 659,488.64$ including GST. I used the Cordell calculator on AA Insurance's website to test these numbers. The calculator asked me to insert the actual address of the property, which I did. I also gave the following parameters: brick cladding, iron roof, $141 \mathrm{sqm}$, and two covered garages. The calculator gave me a quote for replacement sum of $\$ 411,000 .{ }^{339}$ If the Sadats had been insured under a Sum Insured policy for $\$ 411,000$ in reliance of the Cordell calculator, they would have been underinsured by approximately $\$ 250,000$. That would have been significant underinsurance (approximately 38 per cent).

The Cordell calculator does not seem to make specific allowance for contingencies. Experience shows that during a construction project, things can go wrong, or early assumptions misplaced. In Myall v Tower Insurance, ${ }^{340}$ the Court was asked to consider whether an insurer must allow for contingencies when calculating a notional rebuild cost. The answer was yes, and the Court set that at 10 per cent. ${ }^{341}$ The thesis suggests that the Cordell calculator should build a 10 per cent contingency in the repair cost estimate.

The Cordell calculator seems to allow for a standard construction, but the Canterbury experience shows that many houses required costly foundations due to damage to the underlying land. In the interviews, one insurance company pointed out that it is difficult to

\footnotetext{
${ }^{338}$ Sadat v Tower Insurance, above n 293 at [292].

${ }^{339}$ Calculation made in 2019. A later calculation on 22 October 2020 showed the Cordell estimate raised to $\$ 499,000$. It appears that Cordell is updating its pricing year by year which is appropriate.

${ }^{340}$ Myall v Tower Insurance [2017] NZCA 561 at [56], [2017] 19 ANZ Insurance Cases 62-163 where the Court of Appeal confirmed that a "standard allowance" for contingency fees is 10 per cent. See also Avonside Holdings $v$ Southern Response, above $\mathrm{n} 318$.

${ }^{341}$ Myall v Tower Insurance, above n 340 at [56]. See also Avonside Holdings v Southern Response, above n 318.
} 
anticipate the rebuild cost. ${ }^{342}$ About 30 per cent of what this insurer spent in Canterbury was "underground", in foundation costs and addressing land issues. The insurer admitted that no one expected that. This was echoed in an interview with a law firm that surmised that "much damage was to the underlying land... and the litigation that has ensued focused on insurers' response to issues with foundations and [that] foundations [were] extremely expensive to remedy". ${ }^{343}$ In Avonside Holdings $v$ Southern Response, ${ }^{344}$ the Court emphasised that "safe ground" cannot be assumed, not even in a notional estimate. In some cases, the foundations cost was significant. For example, in Young v Tower Insurance ${ }^{345}$ the cost to repair the foundations and sub-floor alone was $\$ 565,800$ due to the house being on a steep and difficult site.

Another cause of concern is Cordell's relatively small allowance for professional fees. Any rebuild requires an architect to design the plans, a structural engineer, possibly a geotech engineer, a project manager, and likely a land surveyor and a quantity surveyor. In addition, there will be building consent fees and sometimes resource consent fees. These costs could easily exceed \$50,000. In Avonside Holdings v Southern Response, ${ }^{346}$ the Court of Appeal accepted an argument that professional fees would be around 10 per cent of the total rebuild cost. It seems safe to apply 10 per cent as a rule of thumb for professional fees.

Cordell seems to allow 5 per cent or less for professional fees. For example, for a threebedroom, two bathroom, 105 sqm quality construction house in Wellington, ${ }^{347}$ Cordell estimates the professional fees at $\$ 23,932$ plus GST (based on an estimated construction cost of $\$ 458,610$ plus GST) so 5.22 per cent; while for a two storey three-bedroom, one

\footnotetext{
${ }^{342}$ Interview with Vero Insurance New Zealand, Insurance Company (Emma Gabor, Auckland, 20 February 2018).

${ }^{343}$ Interview with DLA Piper.

${ }^{344}$ Avonside Holdings $v$ Southern Response, above n 318.

345 Young v Tower Insurance [2016] NZHC 2956 at [104], [2018] 2 NZLR 291.

346 Avonside Holdings $v$ Southern Response, above n 318.

${ }^{347}$ Calculation done for 63 Garden Rd in Wellington on AA Insurance's website using the Cordell calculator on 2 February 2019.
} 
bathroom, 90sqm house of standard construction, ${ }^{348}$ the professional fees were $\$ 6,436$ plus GST (vs a construction cost of $\$ 270,970$ plus GST), so 2.37 per cent. A sum of $\$ 6,436$ plus GST would not be sufficient to cover the professional fees required for the construction of a two storey three-bedroom, one-bathroom house. The building consent fee alone is around $\$ 2,500$. That leaves little for an architect and an engineer, who will certainly be required, or other professionals who might be required.

A point of concern is what appears to be a resistance by some insurance companies to allow a homeowner to choose a Sum Insured that is not aligned with the Cordell estimate. I called an insurance company to discuss the Sum Insurance for a 90sqm, three-bedroom, onebathroom house. ${ }^{349}$ The Cordell calculator estimated the replacement cost to be just above $\$ 250,000$. When I requested a Sum Insured of $\$ 500,000$, I was asked to produce a justification (saying that the Cordell calculator seems incorrect was not sufficient). I also found that some companies that sell house insurance policies online refuse to complete an online purchase if the Sum Insured desired is higher than the Cordell estimate. This is likely to lead homeowners to accept the Cordell estimate, which, as discussed above, might not be accurate.

\section{The danger of underinsurance}

Underinsurance was a significant detractor in resolving claims for multi-unit buildings in Canterbury. ${ }^{350}$ Body Corporates experienced significant underinsurance, which meant they were not able to reinstate the property, leading to disputes on what to do with the insurance proceeds. For fee simple townhouses and cross-lease properties (which were insured individually), underinsurance had a domino effect on the other owners, as the owners had to come up with the money themselves, holding everyone up.

\footnotetext{
${ }^{348}$ Calculation was for 1/119 Tauhara Rd in Taupo done on AA Insurance's website using the Cordell calculator on 2 February 2019.

349 The discussion with the insurer was in December 2017 in relation to 1/119 Tauhara Rd, Taupo.

${ }^{350}$ See full discussion in Chapter IV, Part C6.
} 
According to Treasury it is easy to see "the benefits for insurers of the 'Sum Insured' model, [which means] insurers can predict their overall liabilities with much greater accuracy". ${ }^{351}$ However, Treasury recognised that the move to Sum Insured policies is likely to lead to underinsurance because the new arrangement transfers the responsibility for assessing the rebuild costs to the homeowners, and there is evidence that homeowners are not willing or able to calculate the rebuild costs of their home..$^{352}$

Treasury has undertaken research to the likely level of underinsurance and reported saying: ${ }^{353}$

In doing this research, we were able to access information from insurers, brokers and valuation consultants working in the New Zealand market. We are grateful for their cooperation, particularly in providing us with commercially sensitive information which helped us to build a picture of the cover in place and how it was assessed.

We examined a variety of different approaches to measuring under-insurance, including samples of valuations and rebuilding costs. We concluded that underinsurance was a real issue across New Zealand. The estimates spanned a wide range, both in terms of the number of homes affected, and the amount of under-insurance. Our final assessment was that up to 85 per cent of homes could be under-insured by an average of 28 per cent.

Applying those figures across the whole country produced an estimate of underinsurance across New Zealand of up to $\$ 184$ billion. (emphasis added)

Despite its finding that underinsurance is widespread, Treasury seems confident that the impact of underinsurance is small: ${ }^{354}$

\footnotetext{
351 Treasury 'Sum Insured' Cover for Household Insurance - What Are the Risks? (online ed, 9 May 2016) $<$ https://treasury.govt.nz/publications/research-and-commentary/rangitaki-blog/sum-insured-coverhousehold-insurance-what-are-risks $>$.

352 Treasury 'Sum Insured', above n 351.

353 Treasury 'Sum Insured', above n 351.

354 Treasury 'Sum Insured', above n 351.
} 
To investigate the effect of a realistic major event, we used modelling from the Earthquake Commission to calculate what the under-insurance shortfall might be after a magnitude MW 7.5 event on the main Wellington fault, using the under-insurance assumptions previously identified. This produced a shortfall of around $\$ 135$ million, which is far smaller than the national figure. Most homeowners (95 per cent) would not experience a shortfall at all, but the impact on some households would be severe, with several thousand households facing an average shortfall of around $\$ 40,000$.

On the basis of that modelling, our assessment was that, although under-insurance could cause difficulties for some householders after a major event, the total shortfall would represent only a very small proportion of the overall costs of the event.

It is difficult to reconcile Treasury's assessment. On one hand, they say that underinsurance is a real issue across New Zealand and, based on the information provided by the insurance industry, 85 per cent of houses in New Zealand could be underinsured by a margin of 28 per cent. On the other hand, Treasury modelled a 7.5M earthquake in Wellington and concluded that, based on that modelling, the effect of underinsurance would be small. It is hard to understand Treasury's position.

The data upon which Treasury modelled the Wellington event is recorded in a report titled Home Insurance - Implications of Sum Insured Cover. The report does not appear to have been publicised, but Treasury provided a copy of this report to a third party under an OIA request, and the request together with Treasury's response and report is available on Treasury's own website. ${ }^{355}$

The Home Insurance report acknowledges that there appears to be "a degree of underinsurance across New Zealand. The figures suggest that $40-85 \%$ of homes could be underinsured by 10 to $50 \%$." 356 The report says that similar issues have been identified in

\footnotetext{
355 Treasury Report (T2015/1294) "Home Insurance - Implications of Sum Insured Cover" 23 June 2015, (obtained under Official Information Act 1982 request to Treasury).

${ }^{356}$ Treasury Report (T2015/1294), above n 355 at 2.
} 
Australia, where Sum Insured policies have been in operation for a long time. ${ }^{357}$ However, through some modelling, Treasury worked out that only "a much smaller percentage of households (between 1 and 5\%) would be affected so badly as to exceed their total Sum Insured cover." 358 On that basis, Treasury concluded that "most houses are unlikely to suffer so much damage as to reach the limits of their cover, so the impact would be more limited than the figures suggest". 359

Treasury identified that it was difficult to work out what amounted to underinsurance and pointed out that there are various methods of calculating it. Four calculations were provided in the report with numbers ranging from \$55bn-\$310bn nationally, which, notably, are much higher than what Treasury has modelled (even after taking into account their focus on Wellington only).

One of the four methods was based on the rebuilding costs from Canterbury. In this method, Treasury obtained data from IAG, which is New Zealand's largest insurance company, and from Southern Response, which is the former AMI Insurance company bailed out by the government during the Canterbury earthquakes (and which, significantly, held 30 per cent of the residential insurance market in Canterbury at the time of the earthquakes). ${ }^{360}$ Treasury had a good starting point by selecting two companies that held a large proportion of claims in Canterbury. Treasury wanted to compare customers' Sum Insureds per square metre with the actual rebuild costs arising from the Canterbury rebuild. Of this method, Treasury said: ${ }^{361}$

We believe the figure based on rebuild costs from IAG and Southern Response offer the most accurate reflection of the scale of underinsurance in New Zealand, because the figures are based on the largest dataset of real costs incurred in rebuilding, and

\footnotetext{
357 Treasury Report (T2015/1294), above n 355 at 2.

358 Treasury Report (T2015/1294), above n 355 at 7.

359 Treasury Report (T2015/1294), above n 355 at 2.

360 Steeman, above n 289.

361 Treasury Report (T2015/1294), above n 355 at 8.
} 
information from the largest domestic insurer. These figures suggest that $85 \%$ of homes are underinsured by an average of $28 \%$. (emphasis added)

Despite arriving at this conclusion, Treasury chose a model where they concluded that only a small percentage of houses would suffer enough damage to exceed the Sum Insured. It is not entirely clear how Treasury arrived at the conclusion that a major Wellington event would not lead to more total losses (like Christchurch, for example). This is at odds with the conclusions reached by a Wellington City Council task force that reported to the Minister of Finance in 2019: ${ }^{362}$

\begin{abstract}
We know that the Christchurch and Kaikōura earthquakes will pale into insignificance compared to the complexities of claims for a major Wellington earthquake. About half of Wellington's homes have shared property items (i.e. retaining walls or driveways), half have retaining walls, and more than half contain asbestos. In Christchurch, the 'hard' claims that took the longest to resolve (or remain unresolved) tended to be the ones with complex property ownership, including bodies corporate.
\end{abstract}

Treasury seems to have based their assessment on an assumption that for most cases the Sum Insured will not be tested, and losses will be partial. Such an approach is problematic, and it does not appear to be in line with what a Sum Insured policy is meant to achieve, that is, provide sufficient cover in the event of a total loss. Treasury's signals might encourage homeowners to intentionally underinsure on the basis that the risk of a total loss is small.

I asked a number of interviewees what they thought about the introduction of the Sum Insured policies and impact on multi-unit buildings. Here are the responses of three interviewees.

\footnotetext{
362 Wellington City Council Mayor's Insurance Taskforce: Discussion Document (J009782, online ed, November 2019) <www.buyingtherighthouse.co.nz/site_files/17612/upload_files/J009782-InsuranceTaskforce-Recommendations-Finance-Minister-Pages-Final.._.pdf?dl=1> at 13.
} 
Question So if we had Sum Insured policies at the time of the Shared Property Project, what do you think would have happened?

Answer I think you'd have had a lot of underinsurance and I think you've have had a lot more complexity. The complexity you had with an uninsured or underinsured property... would have been magnified many, many times. ${ }^{363}$

Question What do you think will happen now with the move to Sum Insured policies? Answer An absolute disaster. [F]or the homeowner, and in shared property, for all the others on site, it is a disaster. [It] is also bringing exposure for the banks. ${ }^{364}$

Question So, you think if we had another large natural disaster, we would see a lot of underinsurance?

Answer I know we will. I know we will. ${ }^{365}$

Treasury found that when it comes to setting the Sum Insured, consumers are generally confused between different house values, struggle to price risk, and instead take a shortterm view, and the majority are accepting default Sum Insured values that Treasury says are not necessarily reliable. ${ }^{366}$ Treasury recommends that educating the consumers should fall on the insurance industry, despite finding anecdotal evidence that consumers are not paying attention to such messages because they believe the insurance companies are driven by self-interest. ${ }^{367}$ However, some insurance companies got the message out to customers. On one of their current campaigns, State Insurance has drawn attention to the issue of underinsurance. The campaign estimated that 85 per cent of houses in New Zealand are underinsured. ${ }^{368}$

As part of Money Week 2019, one news article reported an interview with a major insurer on the issue of calculating the Sum Insured. The main message was that it was important for owners to understand how to calculate the rebuild cost, and that it was not the same as

\footnotetext{
${ }^{363}$ Interview with Nine Dots.

${ }^{364}$ Interview with Residential Risk Analysis.

365 Interview with Vero Insurance.

366 Treasury Report (T2015/1294), above n 355 at 13.

367 Treasury Report (T2015/1294), above n 355 at 5.

${ }^{368}$ State Insurance website <www.state.co.nz/house-insurance/home-sum-insured>.
} 
market value or rateable value. ${ }^{369}$ The insurer also pointed out in the article that recent data from Quotable Value, New Zealand's largest valuation and property services company (and also a state-owned enterprise) showed that the cost of construction in the country's main centres increased by 30 per cent over the last ten years; over the same period of time, labour costs rose 17 per cent, and plasterboard, cement, and concrete products increased 13 per cent. All these factors are relevant when having to work out the rebuild cost. The question is, how can homeowners keep the pace with all these increases? It reinforces that insurance cover is not a "set and forget" arrangement but one in which a homeowner needs to be actively involved. But it also highlights the difficulty for a homeowner to accurately calculate the Sum Insured for their home.

Given the danger of underinsurance, there have been suggestions that the government should step in to force insurers to request a certificate of valuation from the homeowners, or else "be disentitled from issuing a policy". ${ }^{370}$ This thesis does not suggest that the recommendation should be adopted, for three reasons.

First, while insurance companies might not object to such a requirement (it does not cost them anything to ask for a valuation certificate), this would likely cause an outcry from the homeowners who would be required to shoulder the cost of obtaining such a valuation or rebuild estimate. The cost to obtain a valuation or a cost estimate from a quantity surveyor varies depending on the size of the house and the level of detail needed. I inquired with three companies that advertise insurance valuation services. ${ }^{371}$ One of them indicated the cost would be $\$ 580$ plus GST (\$667 including GST) and recommended that the valuation be updated every three years. In addition, the valuation cost excluded assessment of any engineered retaining walls due to their specialist nature, so these had to be valued separately. For a homeowner who pays, say, $\$ 2,500$ a year in premium, to add another $\$ 667$ seems a large cost.

\footnotetext{
${ }^{369}$ IAG New Zealand "Kiwis taking miscalculated risk with sum insured" (online ed, 10 September 2019) <www.iag.co.nz/latest-news/articles/Kiwis-taking-miscalculated-risk-with-sum-insured.html>.

${ }^{370}$ Holderness, above n 298.

${ }^{371}$ Prendos, Telfer Young and QV. Prendos was not able to offer a cost estimate as they do not operate in Wellington. Inquiry made in 2020.
} 
Second, these valuations need to be updated regularly to be of any relevance, so this would not be a one-off cost. Some homeowners would find it unattractive to be forced to spend money on the valuation every three years.

Third, obtaining a valuation is far from being a complete solution to the problem. For example, commercial buildings and Body Corporates have always been required to provide regular certificates of valuation. ${ }^{372}$ The Canterbury experience shows that almost every Body Corporate was underinsured. ${ }^{373}$ This was despite having been required to produce a regular valuation certificate from a registered valuer.

When it comes to Sum Insured policies, it is on the policyholders to know their risks, estimate the full rebuild cost of their properties, and take care to set the Sum Insured at the right level. This also needs to be updated every year for inflation or to allow for renovations or extensions, if any. The Sum Insured should be revisited regularly. If the Sum Insured is adequate and there is no underinsurance, the Sum Insured policies will indemnify a policyholder in the same way as a Full Replacement policy would, by paying on a newfor-old basis.

\section{Indemnity Value policies}

The third type of insurance policy available on the market is Indemnity Value policies (sometimes called old for old policies). These cover the policyholder for the repair cost of the property, or, if it is uneconomical to repair, for the market value of the property at the time of the loss, or a specified Sum Insured if one is chosen.

\footnotetext{
372 This is a standard requirement under a Material Damage policy.

${ }^{373}$ Interview with IAG New Zealand; Interview with Young Hunter Lawyers; Interview with Storm McVay (Emma Gabor, Christchurch, 28 November 2017).
} 
An important point is that private insurers do not insure land, so when a policy refers to the indemnity value of a property, it refers to the indemnity value of the improvements only, land excluded. This is an important carveout. And if policyholders are not aware of it, it might lead them to believe that the Market Value of their property is sufficient without thinking that the land is often a large part of that value, but will not be included in the insurance calculation.

Indemnity value policies are different from replacement policies. They restrict payment to "the reasonable costs of repairing or replacing the damaged part of [the] house to the condition it was in immediately before the loss". ${ }^{374}$ In other words, they provide cover on an old for old basis, which allows deductions for depreciation and age of the building or for a settlement based on the diminution in market value of the property due to the damage.

There are multiple ways to determine the indemnity value. Some policies define what indemnity value is, others refer to it as being the market value. For example, an AA Insurance policy defines it as: 375

Indemnity Value

Is our option of:

- the Market Value

- the depreciated replacement cost as assessed by an independent registered valuer appointed by us

- the cost of repairs, less wear and tear and depreciation, but including the cost of complying with government or local authority by-laws or regulations.

Vero Insurance applies a similar interpretation: ${ }^{376}$

374 Medical Assurance Society House Insurance policy wording version IDOM008 12/15. <www.mas.co.nz/assets/application-forms/General-Insurance/House-Insurance/House-insurance-policyIDOM008-1215.pdf>.

375 AA Insurance Home insurance policy wording version AAI_HHOME_V2_1608 <www.aainsurance.co.nz/documents/policy-documents/home-insurance-policy.pdf >.

376 Vero Residential Home policy version VRHP09/15 <www.vero.co.nz/documents/personalinsurance/residential-home-policy-wording-october-2015.pdf>. 
Indemnity value is the amount we deem is needed to compensate you for the change in your financial position as a result of the loss. This is either:

a. for a total loss - the market value of the home immediately before the loss occurred; or

b. for a partial loss -

i. the cost of repairing the damaged portion of the home to a condition no better or more extensive than it was when new, less an allowance for depreciation, age, and wear and tear; or

ii. the reduction in the market value as a result of the loss; but no more than the market value immediately before the loss occurred.

A good starting point is then that indemnity value will be something close to market value in case of a total loss, and the cost of repair less depreciation in case of a partial loss. Reference must be made to the exact terms of the policy.

Cover under an indemnity value policy is less than a policyholder can recover under a replacement policy. In most cases, it is unlikely to be sufficient to enable a complete repair or rebuild of the property and the policyholders will have to contribute from personal funds. Homeowners who choose Indemnity Value policies are at risk of being underinsured. For example, I said in Chapter II that cross-lease properties are cheaper than standalone properties, so that means they have a reduced market value. But that does not mean the rebuild costs are lower than for standalone properties. One homeowner I interviewed shared his experience with other nine owners in a cross-lease development where one owner had an Indemnity Value policy and the unit's value was only about half of what the rebuild costs would have been. ${ }^{377}$ That means the neighbour had to add another 50 per cent of the rebuild cost from their own pocket and this was difficult. It was one of the reasons the reinstatement of that ten-flat property could not proceed.

\section{F Material Damage Policies}

\footnotetext{
${ }^{377}$ Interview with Homeowner 2 (Emma Gabor, via Zoom Christchurch/Wellington, 17 September 2020).
} 
Body Corporates and company shares schemes are insured under commercial Material Damage (MD) policies. ${ }^{378}$ These are similar to a home policy in the sense that they provide cover against the risk of loss or material damage to the property. They also include cover for compliance costs, professional fees, demolition, and removal of debris. Reinstatement is on a new-for-old basis, if the property is insured on a replacement value (but subject to the Sum Insured) or indemnity value if the property is insured on that basis. It depends on the individual insurer offering, but it appears the policyholder has the option to insure on a replacement basis, Indemnity Value basis (also called Present Day value), or something in between, such as Functional Replacement. ${ }^{379}$

They are some differences between an MD policy and a residential house policy. The terms are much denser in an MD policy as there is cover for additional perils, such as plant and business assets owned by a commercial entity. But, after sifting through that, there are three major distinctions relevant to the thesis.

The first is that an MD policy has always been subject to a Sum Insured. So, although the basis of reinstatement is new-for-old, they have a monetary cap. That means they are more susceptible to creating situations of underinsurance. In Canterbury, there were numerous examples of Body Corporates that were underinsured. ${ }^{380}$ But the good thing is that if the Sum Insured is adequately set, MD policies can provide the same level of reinstatement as a Full Replacement policy.

The second distinction is that the insurer has the right to request a valuation in support of the Sum Insured. By contrast, residential Sum Insured policies introduced in 2013 do not require valuations.

\footnotetext{
${ }^{378}$ Interview with IAG New Zealand; Interview with Roger Phillips.

379 See FMG policy wording version 2484 07/16 VEL3302 <www.fmg.co.nz/globalassets/what-wecover/policy-wordings/policy-wording-2017-18/material-damage-policy-wording-2017-18.pdf>; YPM wording www.ypm.co.nz/assets/2016-Insurance/YPM-agreed-wording-with-NZI-2016-v2.pdf; State Material Damage policy SI4273/8 03/15 <www.state.co.nz/PDFs/State_Material_Damage_PW.pdf.

${ }^{380}$ Interview with IAG New Zealand; Interview with Young Hunter; Interview with RAS.
} 
The third distinction is that the excess provisions are different. MD policies will usually set out the excess as a percentage of the Sum Insured Residential policies set the excess as a fixed sum (commonly $\$ 5,000$ for natural disaster claims). ${ }^{381}$

\section{G The EQC Scheme}

In addition to private insurance, in New Zealand there are also certain types of insurance created by statute. The Accident Compensation scheme (or ACC) ${ }^{382}$ and EQCover are both insurance schemes where a risk is transferred to a Crown entity by the application of an Act of Parliament. In these cases, premiums are funded by levies.

The EQC Act provides for the establishment of a scheme of statutory insurance for natural disasters where EQC administers claims covered by the EQC Act. This statutory cover is known as EQCover. The EQC Act has its roots in the War Damage Act 1941, which provided compensation for war damage. That Act became the Earthquake and War Damage Act 1944 and then the scheme was substantially changed in 1993 with the passing of the EQC Act.

According to EQC's website, EQCover is EQC's natural disaster insurance for homes and land. Despite its name, EQC provides cover for more than just earthquakes. "Natural disaster" is defined in $\mathrm{s} 2$ of the Act as: ${ }^{383}$

(a) an earthquake, natural landslip, volcanic eruption, hydrothermal activity, or tsunami; or

(b) natural disaster fire; or

(c) in the case only of residential land, a storm or flood.

\footnotetext{
${ }^{381}$ Excess are lower for claims not involving natural disasters, both for MD policies and residential Sum Insured policies.

${ }^{382}$ Established by Accident Compensation Act 2001.

${ }^{383}$ EQC Act.
} 
The EQC cover dovetails ${ }^{384}$ with the private insurance cover in that a policyholder under a house insurance policy has automatic cover under EQC if the policyholder had a contract of fire insurance over a residential building.

The EQC cover is one of the major reasons New Zealand homeowners are so well insured. EQC provides the first $\$ 150,000$ plus GST of a loss, which acts as a massive excess and reduces exposure and cost for the insurer. Treasury says that EQC's involvement keeps cover against natural disasters affordable. ${ }^{385}$

EQC's obligations related to residential buildings are set out in section 18 of the Act. This sets out the basis of insurance, which is replacement basis, and if the underlying policy is a Sum Insured policy, then the limit is the Sum Insured if the Sum Insured is under cap. ${ }^{386}$ In Canterbury, some cross-lease owners had a Sum Insured policy that was at or below the EQC cap of $\$ 100,000$ plus GST as it was then. ${ }^{387}$ Once EQC paid, there was no more money to claim from the insurer.

EQCover does not apply to commercial buildings. This is only relevant to the thesis in that sometimes Body Corporates had a mixed-use element, for example by having commercial space at the ground floor. This made it more complicated for EQC to calculate their share of the contribution as EQC excludes commercial properties. This was different from private insurers who did not make such a distinction.

EQCover is provided on a Full Replacement basis, that is, new-for-old, subject to the statutory cap. Notably, when it comes to buildings, EQC provides cover on a Full Replacement basis even if the underlying insurance policy is an indemnity value policy. ${ }^{388}$ While the insurers' obligations are specified in the insurance contract, EQC's obligations

\footnotetext{
${ }^{384}$ Goodier v Earthquake Commission [2019] NZHC 2176 at [26].

385 Treasury New Zealand's Future Natural Disaster Scheme, above n 277.

${ }^{386}$ EQC Act.

${ }^{387}$ Interview with Residential Risk Analysis.

${ }^{388}$ Note however that cover for bridges, culverts and retaining walls that support the home are only covered for indemnity value.
} 
are statutory, so each are bound by their respective obligations. This is likely to have caused confusion between owners, especially in the context of assigned insurance claims. I return to this point in Chapter IV where I analyse the misunderstandings related to how much a purchaser could claim under an assigned claim.

To be able to claim on EQC, a homeowner must lodge a claim within the statutory timeframe from the date of the natural disaster event. ${ }^{389}$ Between 1993 and 2019 (which, notably, includes the period of the Canterbury and the Kaikōura earthquakes), the statutory timeframe for notifying a claim was three months. EQC had no discretion to extend this time even if there were justified causes for delay. ${ }^{390}$ This timeframe was very short and inadequate for a large disaster. It gave rise to some issues for those who did not make a claim within the required statutory timeframe, as they lost the opportunity to receive cover from EQC.

In 2019, the EQC Act was changed to give EQC discretion to receive claims if they had been notified within two years of the damage occurring. ${ }^{391}$

Currently, EQC's liability is limited to $\$ 150,000$ plus GST ( $\$ 172,500$ including GST). This is referred to as the cap. Between 1993, when the EQC Act was enacted, to July 2019, when the Act was updated, ${ }^{392}$ the cap was $\$ 100,000$ plus GST. Importantly, this included the period of the Canterbury and the Kaikōura earthquakes.

When the EQC Act was passed in 1993, "the idea was that the EQC cover would be sufficient to rebuild a modest home" 393 and the intention of the Act was that most homeowners were to have cover for natural disaster claims under the Act without having

\footnotetext{
${ }^{389}$ EQC Act, Schedule 3, cl 7(2).

${ }^{390}$ EQC "Householders' Guide to EQCover" <www.eqc.govt.nz/sites/public_files/EQC_HouseHoldersGuide_WEB.pdf> at 17.

${ }^{391}$ Earthquake Commission Amendment Act 2019, s 7. This was then enshrined into the EQC Act in Schedule $3, \operatorname{cl} 7(2)$.

392 Earthquake Commission Amendment Act 2019.

393 (29 March 2018) 728 NZPD 2774; Mayor's Insurance Taskforce, above n 362 at 13.
} 
to make a claim with the private insurer. The cap of $\$ 100,000$ plus GST was based on a calculated replacement cost of an average house in New Zealand. That means the scheme was not meant to establish a dual insurance system. However, with the rapid increase in construction costs in New Zealand, by the time of the Canterbury earthquakes, the cost to rebuild a home increased past the EQC cap, which meant that EQC and insurers had to work side by side on almost every claim, leading to duplication of work and delays.

Where damage occurs in multiple events, EQC is liable to pay one cap per event, even if the damage is not repaired between the successive losses. ${ }^{394}$

In buildings with more than one dwelling such as Body Corporates, EQC applies one cap per dwelling. Dwelling is defined as any self-contained premises that are or can be, or are intended to be a home or a holiday home. ${ }^{395}$ So in an apartment building with, say, 50 apartments, EQC would pay up to the cap for each of the 50 units. For an apartment block with 50 units, the level of EQC cover would be \$8,625,000 including GST. ${ }^{396}$

As to the relationship between EQC and a policyholder, the Court declared that "while the relationship between the parties is not contractual, it remains nonetheless an arrangement of insurance and ... ordinary principles of insurance law and practice apply."397

Like a private insurer, EQC has a discretion in how it administers or settles a claim. This is set out in s 29 of the Act, which gives EQC a discretion to pay, replace, or reinstate at its option. Once EQC exercises that discretion, the election is open to challenge only on certain grounds. ${ }^{398} \mathrm{EQC}$, like private insurers, have decision-making powers in the context of a claim. This adds another layer of decision dependency for natural disaster claims.

\footnotetext{
${ }^{394}$ Re Earthquake Commission, above n 330.

395 EQC Act, s 2.

39650 x $\$ 150,000$ cap per unit plus GST.

${ }^{397}$ C \& S Kelly Properties v Earthquake Commission [2015] NZHC 1690 at [61].

398 That the decision was arbitrary, capricious, unreasonable or made in bad faith. For a full discussion see $C$ \& S Kelly Properties v Earthquake Commission, above n 397.
} 
Unlike private insurers, EQC also provides cover for land. ${ }^{399}$ Land cover is unique to EQC; and is it not offered in any other country. ${ }^{400}$

Land cover is complex. In an explanatory booklet, ${ }^{401}$ EQC describes that land cover is limited to land under the home and outbuildings (such as a shed or garage); land within eight metres of the home and outbuildings; and land under or supporting the main access way, up to 60 metres from the home (but not the driveway surfacing); it includes bridges and culverts within the above areas; retaining walls if they are necessary to support or protect the home, outbuildings, or insured land; and the removal of debris, such as silt or fallen trees, from the insured land (but not replacement of items on the land, such as trees, plants, lawn, and driveways).

EQC pays the lesser of either the cost to repair the damaged land, or the value of the damaged land, or the value of 4,000 sqm, or the value of the minimum-sized building site allowed in the area in which the policyholder lives, whichever is the lower. ${ }^{402}$

There is some mismatch between the cover provided by EQC and the private insurer, with EQC covering land, bridges, and culverts while the private insurer does not; and the private insurer covering retaining walls, driveways, fences, and other external works excluded by EQC. Such external works have come to be referred to by insurance companies as "out of scope" because they are not covered by the EQC Act.

The EQC Act is currently under review. ${ }^{403}$ This follows earlier changes in 2019 when the cap was increased, contents cover was removed, the period for notification of claims was

\footnotetext{
${ }^{399}$ EQC Act, s 19.

${ }^{400}$ Cartwright, above n 278 at 151.

${ }^{401}$ EQC "Land Cover" <www.eqc.govt.nz/what-we-do/land-cover>.

402 See <www.eqc.co.nz> and also EQC Act, s 19.

403 Treasury Review of the Earthquake Commission Act (online ed, 12 February 2021) <www.treasury.govt.nz/news-and-events/reviews-consultation/review-earthquake-commission-act>.
} 
extended, and provisions were introduced to allow better sharing of information related to claims and property. ${ }^{404}$

\section{H Insurance Cover for Natural Disaster Damage}

Most home insurance and Material Damage policies contain an exclusion for loss caused by natural disasters, including earthquakes. Cover is brought back via automatic extensions providing what is commonly known as "top up" cover but subject to conditions. These conditions relate to a loss being covered by the EQC Act, and EQC having accepted and paid the claim up to the statutory cap. The provisions are meant to convey that cover would only be engaged once EQC has paid the cap. Until then, there is no cover under the policy. In Jarden v Lumley General, the Court of Appeal held that the top-up liability of a private insurer does not arise until EQC's actual legal liability under the Act is established. ${ }^{405}$

Policy wordings differ in how they apply the natural disaster extension. Some policies require there to be an actual payment from EQC to the full cap before the policy is triggered. ${ }^{406}$ Others, however, provide for cover calculated as the difference between what EQC has paid or should have paid if certain things had happened. ${ }^{407}$ While it might appear to be a simple choice of words, there could be a difference. For example, if a policyholder fails to lodge a claim with EQC within the prescribed statutory timeframe, the policyholder would not be entitled to an EQC payment. On a strict interpretation of the policy, the policyholders would not be able to make a claim on the private insurer as EQC had not paid the cap. Some insurers have drafted the wordings to recognise that in these situations, policyholders should still be entitled to the top-up amount they would have had under the private insurance cover. The impact of the more restrictive policies has lessened now due to the changes to the EQC Act that came into effect in 2019 and that allow a policyholder

\footnotetext{
${ }^{404}$ Earthquake Commission Amendment Act 2019.

405 Jarden v Lumley General Insurance (NZ) Ltd, above n 330. That case concerned a residential property partly damaged by the Canterbury earthquake. One of the issues before the Court of Appeal was to determine in what circumstances does the insurer's liability to provide top up cover commence.

406 Vero policy, AA policy referenced above.

${ }^{407}$ State Comprehensive policy above.
} 
to notify a claim within two years of an event. ${ }^{408}$ This is good because the aim is for the policyholder to claim the maximum amount possible so they have sufficient funds to reinstate.

Cover is for the difference between the maximum entitlement under the policy and the EQC payment/cap. If a policyholder has a \$500,000 Sum Insured and they suffer a loss caused by a natural disaster, the most the policyholder could get from the insurer is $\$ 500,000$ less the EQC cap of $\$ 172,500$ including GST $=\$ 327,500 .{ }^{409}$ This can make a significant difference where the property is not adequately insured. In the case Firm PI 1 Ltd v Zurich Australian Insurance, ${ }^{410}$ a Body Corporate had a Sum Insured of \$12.95 million. It suffered significant damage in the Canterbury earthquakes to the effect that the reinstatement costs were estimated at $\$ 25$ million. EQC made various payments totalling $\$ 6.8$ million. The insurer offered the difference between Sum Insured and the EQC payment (which came to $\$ 6.15$ million), but the Body Corporate wanted the full Sum Insured to be paid in addition to the EQC payment. The Court disagreed and held that the EQC cover was provided as the difference between the Sum Insured and the EQC payment. This comes back again to underinsurance and the importance of setting the Sum Insured correctly. Underinsurance is a real issue and I discuss it again in Chapter V when I propose solutions to this problem.

\section{Conclusion}

This chapter provides a window into the insurance arrangements in New Zealand. At the time of the Canterbury earthquakes, the prevalent type of policies for residential homes were Full Replacement policies that provided cover on a new-for-old basis with no monetary limit. That meant homeowners had sufficient funds to reinstate regardless of escalation of cost. However, following the Canterbury earthquakes, the offering in New Zealand changed and most insurance companies introduced monetary caps called Sum

\footnotetext{
${ }^{408}$ EQC Act 1993, Schedule 3, cl7(2).

${ }^{409}$ Some policy limits might be on a plus GST basis. However, for the purpose of the thesis, we will use round numbers as examples.

${ }^{410}$ Firm PI 1 Ltd v Zurich Australian Insurance [2014] NZSC 147, [2015] 1 NZLR 432.
} 
Insureds. This means owners need to be extremely careful when selecting their Sum Insured to ensure that they have enough funds in case of a total loss. The problem is that not everyone understands how to calculate the Sum Insured. So, there is an increased risk of underinsurance going forward. Underinsurance affects multi-unit buildings in a more significant way, as I discuss in the next chapter.

The existence of the EQC scheme for natural disasters brings relief by providing an automatic cover up the statutory cap of $\$ 150,000$ but often this is not sufficient to reinstate the damage in case of a total loss. While the EQC scheme is beneficial, it creates a dual insurance system which has the potential to complicate claims. This is also discussed in the next chapter. 


\section{DIFFICULTIES IN RESOLVING MULTI-UNIT BUILDING CLAIMS: THE CANTERBURY AND THE KAIKŌURA EXPERIENCE}

New Zealand is highly vulnerable to natural hazard risks. ${ }^{411}$ ICNZ has kept records of natural disasters since 1968, including the insurance cost of these disasters. ${ }^{412}$ ICNZ has recorded 198 natural disaster events in the last 53 years. ${ }^{413}$ That is an average of four natural disaster events every year. There are some good years with fewer than four events, but also some bad years with more than four events. For example, between December 2019 and December 2020 (the most recent one-year period), there were nine natural disaster events, which cost nearly $\$ 265$ million. So natural disasters occur with regular frequency.

In October 2012, Lloyd's Global Underinsurance Report ranked New Zealand as the third most vulnerable economy in the world to natural catastrophe, after Bangladesh and Chile. ${ }^{414}$ This took into account the probability of a natural disaster and the cost of a natural disaster to determine the impact on the local economy. Unfortunately for New Zealand, the probability of a natural disaster is high, and the cost is also high, resulting in significant risk to the economy if the losses are uninsured.

In its latest ten-year report on resilience strategy, ${ }^{415}$ EQC points to two significant challenges facing New Zealand. The first arises out of the geographical location of the

\footnotetext{
411 ICNZ "Protecting New Zealand from Natural Hazards" (October 2014) <www.icnz.org.nz> at 5 <www.icnz.org.nz/fileadmin/Assets/PDFs/Publications/icnz-protecting-nz-from-natural-hazards20141.pdf>.

412 ICNZ "Cost of Natural Disasters" <www.icnz.org.nz>.

413 ICNZ "Cost of Natural Disasters", above n 412.

${ }^{414}$ Centre for Economics and Business Research Lloyd's Global Underinsurance Report (online ed, October 2012) <www.lloyds.com/ /media/Files/News\%20and\%20Insight/360\%20Risk\%20Insight/Global_Underinsuranc e_Report_311012.pdf>.

415 EQC Resilience Strategy for Natural Hazard Risk Reduction 2019-2029 (online ed, November 2019) <www.eqc.govt.nz> at 3 .
} 
country, which sits at the boundary of two active tectonic plates, and which creates high risk of catastrophic hazards such as earthquakes, landslides, volcanic activity, and tsunami. The second challenge arises out of climate change, which increases New Zealand's exposure through more frequent and severe extreme weather events, and through sea level rise. $^{416}$

Sir Geoffrey Palmer, a former Prime Minister put it well: ${ }^{417}$

Sometimes it does us a power of good to remind ourselves that we live on two volcanic rocks where two tectonic plates meet, in a somewhat lonely stretch of windswept ocean just above the roaring forties. If you want drama - you've come to the right place.

It is not surprising then that claims for natural disaster damage make up a significant percentage of the annual claims received by insurance companies. Therefore, examining claims for natural disaster damage in the context of the thesis is important.

The Canterbury earthquakes are the perfect case study because they provide abundant examples of multi-unit building insurance claims. EQC reported around 20,000 multi-unit building claims involving nearly 30,000 individual dwellings. ${ }^{418}$ The Kaikōura earthquake was smaller in comparison, but it provides great context and a good point of difference for the learnings coming from Canterbury. But first it is important to understand what happened in Canterbury.

\footnotetext{
${ }^{416}$ EQC Resilience Strategy, above n 415 at 3.

${ }^{417}$ Ministry of Civil Defence \& Emergency Management Resilient New Zealand - A Aotearoa manahau: national civil defence emergency management strategy - 2003-2006 (Wellington, 2004). Cited in Eileen McSaveney and Simon Nathan, 'Natural hazards - overview - Living dangerously' Te Ara - the Encyclopedia of New Zealand <www.TeAra.govt.nz/en/natural-hazards-overview>, at 1.

418 EQC "Multi-Unit Buildings: Multi-unit buildings FAQs-expanded tab" (online ed, 12 July 2019) <www.eqc.govt.nz>.
} 


\section{A The Canterbury Earthquakes}

On 4 September 2010, a major 7.1M earthquake struck the city of Christchurch and the surrounding Canterbury region. Many aftershocks followed, including a devastating one on 22 February 2011 and other powerful aftershocks on 26 December 2010 and 13 June 2011. In total, there were almost 18,000 aftershocks following the 4 September 2010 earthquake, including 35 events of magnitude five or greater. ${ }^{419}$ As well as considerable loss of life, there was widespread damage to property, land, and infrastructure. Around 167,000 homes were damaged, representing 90 per cent of greater Christchurch's housing stock. $^{420}$ The Canterbury earthquakes were the largest and most damaging natural disasters encountered in recent New Zealand history. ${ }^{421}$

As of 25 April 2020, private insurers paid $\$ 22,883,000,000$ (\$22 billion). ${ }^{422}$ EQC paid $\$ 10$ billion. ${ }^{423}$ In addition, the Crown spent an estimated $\$ 17.5$ billion providing "innovative support services such as the Residential Advisory Service, the Earthquake Support Subsidy and the Canterbury Earthquake Temporary Accommodation Service". ${ }^{424}$

The Canterbury earthquakes were the eighth most expensive natural catastrophe in global history since 1970 measured in terms of insurance losses. ${ }^{425}$

The Canterbury earthquakes have been the most insured events in the world for the period 1980-2014, with up to 78 per cent of losses being insured, compared with the

\footnotetext{
${ }^{419}$ Department of the Prime Minister and Cabinet Greater Christchurch Group Whole of Government Report: Lessons from the Canterbury earthquake sequence" (online ed, 30 July 2017) <www.dpmc.govt.nz> at 67 [Whole of Government Report]

${ }^{420}$ Whole of Government Report, above n 419 at 13.

${ }^{421}$ Cartwright, above n 278 at 8.

422 ICNZ "Cost of Natural Disasters”, above n 412.

${ }^{423}$ ICNZ "Canterbury Earthquakes" < www.icnz.org.nz>.

424 Whole of Government Report, above n 419 at 5.

${ }^{425}$ Whole of Government Report, above n 419 at 63, citing Munich Reinsurance Company "Catastrophes: Global" (February 2017) Insurance Information Institute <www.iii.org>.
} 
earthquake/tsunami in Japan in March 2011 with only 19 per cent of losses being insured or the earthquake series in Italy in 2012 with only 10 per cent of the losses insured. ${ }^{426}$

At the time of the Canterbury earthquakes, EQC had $\$ 5.6$ billion in its Natural Disaster Fund and $\$ 2.5$ billion in reinsurance cover. ${ }^{427}$ EQC's funds were completely exhausted by the event. The Crown provided additional money to cover the deficiency in the fund. ${ }^{428}$

There were several complex and unique insurance issues arising out of the Canterbury earthquakes. These were not specific to multi-unit buildings but affected multi-unit buildings as well, and they inform the context in which multi-unit building claims were resolved.

\section{The unprecedented scale of the disaster}

The Canterbury earthquakes were of an unprecedented scale. In its 2012-2013 annual report, EQC said: ${ }^{429}$

It is easy to forget that the Canterbury earthquakes have resulted in the largest volume of insurance claims in New Zealand's history, and have generated the fourth largest insurance event in global history. New Zealand, Canterbury and EQC have therefore been confronted with unparalleled challenges. EQC has received 467,406 insurance claims, representing a total of 736,657 separate exposures for buildings, land and contents.

The size of the event must be taken into account when assessing the impact of the disaster.

\footnotetext{
${ }^{426}$ Figures taken from Treasury New Zealand's Future Natural Disaster Scheme, above n 277 at 1.

${ }^{427}$ Whole of Government Report, above n 419 at 63.

${ }^{428}$ EQC Act, s 16.

${ }^{429}$ EQC Annual Report 2012-2013.
} 


\section{Successive events}

Neither the private insurers nor EQC envisaged a sequence of events that would result in successive and compounding losses. Houses suffered multiple loses from aftershocks. Each aftershock caused damage, which was insured. Because of this, it was unclear whether EQC's responsibilities were limited to $\$ 100,000$ plus GST for losses from all aftershocks combined, or whether the EQC cap applied per event. This led to disputes between insurance companies in relation to liability for later events. ${ }^{430}$ The issue required judicial guidance, and the High Court decided that EQC's liability was to be calculated per event. ${ }^{431}$ Therefore \$100,000 plus GST was available for each aftershock that caused damage. While this provided clarity in one area, it created complexity in assessing the impact of each event and apportioning losses between events. This was especially difficult, given that most of the apportioning assessments had to be done retrospectively and without a technical inspection having been carried out between events, either due to safety reasons or because of a lack of resources.

\section{Land damage}

There was widespread damage to land. This led to delays in resolving insurance claims for five reasons.

The first was that it was unclear whether the remediation of land damage was covered by the building insurance (EQC and private insurers together) or by the land insurer (EQC only). This created uncertainty and delays in resolving insurance claims because the insurers needed to decide whether to repair the land or enhance the building foundations to compensate for the compromised land, and in particular who was responsible for paying

\footnotetext{
${ }^{430}$ Finn Legal Response to Natural Disasters, above n 7 at 197.

${ }^{431}$ Re Earthquake Commission, above n 330.
} 
for the losses arising out of the land damage. ${ }^{432}$ Of particular difficulty were situations where there was little or no damage to the house, but significant damage to the land. ${ }^{433}$

The second reason was related to land that became prone to flooding and liquefaction. This was known as Increased Flooding Vulnerability and Increased Liquefaction Vulnerability. It was an issue of great significance. ${ }^{434}$ EQC did not know whether the fact that the land became prone to risk was "damage" as defined by the EQC Act, and, if yes, how it should resolve these claims. EQC sought Court declarations to give effect to a policy it developed in relation to those claims. ${ }^{435}$ The Court concluded that both Increased Flooding Vulnerability and Increased Liquefaction Vulnerability constituted natural disaster damage to land. ${ }^{436}$ Homeowners raised the question whether Increased Flooding Vulnerability also constituted damage to buildings. If it did, the homeowners would have had recourse to their private house insurance cover rather than just the land cover with EQC. The Court concluded that where there has been no change to the physical state or integrity of the structure caused by the subsidence, that was land damage only. ${ }^{437}$ The Court decision clarified the situation and enabled the parties to progress their claims, but, like any judicial process, it took some time to come to a conclusion, and in this time claims could not be advanced.

\footnotetext{
${ }^{432}$ Cartwright, above n 278 at 156.

${ }^{433}$ Finn Legal Response to Natural Disasters, above n 7 at 199.

${ }^{434}$ Preliminary modelling available as of December 2014 indicated that about 13,500 properties were subject to increased risk of flood following the earthquakes. See Earthquake Commission v Insurance Council of New Zealand, above n 330.

${ }^{435}$ EQC joined ICNZ, Christchurch City Council and Southern Response as defendants to the proceedings. ICNZ was joined as a representative of insurance companies in New Zealand; the Council as the local authority responsible for the land affected, and Southern Response as a Crown entity which had taken over the earthquake claims of a failed insurance company, AMI Insurance, and which had a large share market in Christchurch. In addition, there were two interveners. One was the Flockton Cluster Group, a group of owners affected by increased risk of flood. The second intervener was a Ms Culf. She was an owner, and her property was affected by both ILV and IFV. She had chosen to remain in the Red Zone. The Court also appointed two amici curiae. Mr Weston QC was appointed to represent homeowners affected by the earthquakes. Ms Clark QC was appointed as a contradictor, to challenge the Court's powers to make declarations in relation to the issues put before it.

${ }^{436}$ Earthquake Commission v Insurance Council of New Zealand, above n 330.

${ }^{437}$ Earthquake Commission v Insurance Council of New Zealand, above n 330.
} 
A third reason, closely related to the first two, was that EQC chose to pay Increased Flooding Vulnerability and Increased Liquefaction Vulnerability claims on a diminution in value basis, rather than the actual cost of repairs. Similar to the distinction between an Indemnity Value policy and a Full Replacement policy, diminution in value is generally less than the actual cost of repair. The EQC Act gives EQC the right to choose the basis of reinstatement and EQC can choose the lower of the two. It seems EQC chose a mixed response. The media reported that EQC chose to settle two thirds of the Increased Flooding Vulnerability and Increased Liquefaction Vulnerability claims on a diminution in value basis (at an average of $\$ 24,000$ each), and one third of claims by undertaking actual repairs (at an average cost of $\$ 65,000) .{ }^{438}$ EQC made around 100,000 cash payments for land claims. ${ }^{439}$ Cash payments are generally made where insurers do not take part in the repairs. That suggests that a large number of homeowners were paid on a diminution in value basis, and therefore did not receive sufficient funds to enable them to remediate the land. What that meant was that the land was not suitable to build on because it had not been remediated. This led to tensions with the insurance companies (going back to the first reason mentioned above), as homeowners expected the insurers to pay for more robust foundations to compensate for the lack of appropriate land conditions. It appears that insurers proceeded with paying the additional costs but sought an assignment of the homeowners' rights to pursue EQC for more money later. ${ }^{440}$ In July 2018, this was still a live issue between private insurers and EQC. ${ }^{441}$

The government undertook extensive geotech assessments of land. The zoning created a stalemate in resolving insurance claims as remediation of buildings could not proceed. This was the fourth reason for delay. The green zone was deemed safe to build on but CERA further divided it into three technical categories: TC1 (grey), TC2 (yellow), and TC3

\footnotetext{
438 John McCrone "Did EQC save big on Christchurch land claims?" Stuff (online ed, 29 July 2016).

439 (26 May 2016) 714 NZPD 11335.

${ }^{440}$ IAG New Zealand "Submission to the Ministry of Business, Innovation and Employment on the Insurance Contract Law Review" (13 July 2018) <www.mbie.govt.nz> at 24.

${ }^{441}$ IAG New Zealand "Submission on Insurance Contract Law Review", above n 440 at 24.
} 
(blue). ${ }^{442}$ The Ministry of Building Innovation and Employment (MBIE) then issued guidance on repairing properties in the different technical categories. ${ }^{443}$ The categorisation of land and development of a guidance meant insurers could not confidently assess or repair TC2 and TC3 homes until the guidance was issued. ${ }^{444}$ TC2 and TC3 land required geotechnical assessments before work could be carried out. This took time to complete.

The fifth reason was that some land was damaged beyond economic repair. Approximately 190,000 properties were assessed, of which about 180,000 were zoned "green" and 8,060 properties were zoned "red". ${ }^{445}$ The land zoned red was deemed unsafe to build on. Between 2011 and 2015 the government announced a series of offers to purchase properties in the residential red zone. The owners had a choice to sell the land and retain the ownership of the house (and settle the house claim with the insurer), or to sell both house and land to the Crown, assigning the insurance rights to the Crown. By April 2016, 98 per cent of owners took up to Crown offer in one form or another. ${ }^{446}$ In total, approximately 197 hectares of land in the Port Hills, and 600 hectares of flat land were zoned red. ${ }^{447}$ Where the land was zoned red, policyholders needed to find other land to rebuild, or had to settle their claims by purchasing another property or via a cash settlement.

\section{The dual insurance system}

As mentioned before, when it comes to natural disasters, New Zealand has a dual insurance system. In the Canterbury earthquakes, the first layer of cover was provided by EQC. EQC had to assess every damaged property to determine whether the damage was within the EQC cap or above. If the loss was above the cap, EQC would refer the matter to the private

\footnotetext{
442 The Canterbury Earthquake Recovery Authority (29 March 2011) Department of the Prime Minister and Cabinet <www.mbie.govt.nz>.

${ }^{443}$ MBIE Repairing and rebuilding houses affected by the Canterbury earthquakes (ISBN 978-0-478-399080, online ed, 1 December 2012) <www.building.govt.nz>.

${ }^{444}$ IAG New Zealand "Submission on Insurance Contract Law Review”, above n 440 at 23.

445 Whole of Government Report, above n 419 at 52 and 55.

446 Whole of Government Report, above n 419 at 55.

${ }^{447}$ Whole of Government Report, above n 419 at 10.
} 
insurer. The dual handling of insurance claims between EQC and the private insurers added a level of complication and delay in resolving claims for four main reasons.

The first was that EQC held ownership of undercap claims and was slow in releasing them to the private insurers. Sometimes it took years for EQC to come to an agreement that the loss was overcap and to hand over the claim to the private insurer. One insurer thought EQC added 6-12 months to the process. ${ }^{448}$ Another found EQC good to deal with when it came to Body Corporates' claims, but thought that it held on to the undercap claims "for a long time ... 3-4 years." ${ }^{\text {449 }}$ In 2018, eight years after the first earthquake, EQC was still reporting new claims to the insurers on the basis that $\mathrm{EQC}$ re-assessed them as overcap. ${ }^{450}$ And in its annual report to 30 June 2018, EQC reported that they had 556 Canterbury claims remaining. ${ }^{451}$ While some of these claims might stay within the EQC cap, some of them might be overcap claims that need to be referred to the private insurers. The fact that they have not been resolved for so many years suggests a level of complexity and a potential increase in cost that could push them over the EQC cap.

While EQC have ownership of the claims, private insurers are not able to progress matters, leading to significant delays and inconvenience for everyone involved.

The second reason, very much linked with the first, was the duplication of work. Once EQC notified an insurer that a claim was overcap, the insurer would start the damage assessment afresh, and a new repair investigation. There was no benefit from EQC's previous investigation. The process was completely separate. One interviewee expressed disappointment with the process: 452

EQC goes through first [...]. They do their geotech [investigation] then they do their structural assessments but they don't release that to the private insurer so we have to

\footnotetext{
${ }^{448}$ Interview with Vero Insurance.

${ }^{449}$ Interview with IAG New Zealand.

${ }^{450}$ IAG New Zealand "Submission on Insurance Contract Law Review", above n 440 at 25.

${ }^{451}$ EQC Annual Report 2018-2019.

${ }^{452}$ Interview with Residential Risk Analysis.
} 
go and do it as well. So you've got double the resources going into that house. It was ridiculous and the private insurer had to wait around because we could do nothing until EQC passed it over. We might have thought this was overcap, definitely ours, for years before EQC could see it is. Not good.

The third reason was related to EQC's own history and experience. In its everyday operations, EQC is managed as a small financial institution. At the time of the Canterbury earthquakes, it had 22 permanent staff. ${ }^{453}$ EQC had to upscale its operations to be able to manage the overwhelming number of claims received. It is no surprise progress was slow. EQC had to manage its own internal growth, while also dealing with an unparalleled and devastating sequence of events that created hundreds of thousands of claims, many of them complex.

In addition, at the government's direction, after the September 2010 earthquake, EQC changed its ways of managing claims, from cash settlements to managed repairs. EQC never planned to manage repairs on a mass scale, nor was it geared for such an undertaking, but at the government's orders, it started managing repairs. ${ }^{454}$ EQC managed over 67,000 repairs through the Canterbury Home Repair Programme. ${ }^{455}$ A public inquiry report into the EQC concluded that the government's decision to task EQC with managing repairs was "a mistake". 456

The fourth reason for the complications added by the dual insurance system was that there was no alignment between EQC and the private insurers in relation to assessments of loss and dealing with claims. They each had their own internal standards. This was confirmed in an independent review following the Kaikōura earthquake where EQC gave authority to

\footnotetext{
${ }^{453}$ Whole of Government Report, above n 419 at 63.

${ }^{454}$ Cartwright, above n 278 at 14; Treasury - Cabinet Paper "Government Response to the Public Inquiry into the Earthquake Commission" (25 June 2020) DEV-20-SUB-0116 $<$ www.treasury.govt.nz/publications/cabinet-paper/dev-20-sub-0116-government-response-public-inquiryearthquake-commission> at [5].

${ }^{455}$ Cartwright, above $\mathrm{n} 278$ at 44.

${ }^{456}$ Cartwright, above n 278 at 139.
} 
private insurers to deal with and settle EQC claims. The report says that EQC incorrectly assumed that insurers only needed minimal training and that the EQC Act and the insurance policies were "back-to-back", meaning they only needed to identify the differences. ${ }^{457}$ EQC found that more training was required and that insurers were not interpreting or applying the same standards as EQC. ${ }^{458}$

During the Canterbury earthquakes, there was inconsistency in terms of dealing with preexisting damage and the standard applied to re-level a property. EQC's stance on dealing with damage and repairs led a group of 98 Canterbury property owners, who called themselves the EQC Action Group, to issue proceedings against EQC. ${ }^{459}$ The proceeding settled, and a public Joint Statement was issued on 26 April 2016 to the effect that EQC was confirming agreement or changing the way it interpreted the standard of repairs. ${ }^{460}$

\section{Advocates}

Following the Canterbury earthquakes, a number of insurance advocates started offering assistance with insurance claims. Some companies were from overseas. The advocates usually made arrangements where they would be paid a share of the insurance settlement money on a no win no fee basis. ${ }^{461}$ In a court case involving one of these advocacy providers, the Court described the arrangement: ${ }^{462}$

On the information before us Mr Staples had been very successful in Christchurch in attracting such claims work from these vulnerable people. Indeed it seems clear that

\footnotetext{
457 Acuo Ltd "Review of Kaikōura Earthquake Response Part 1" (September 2017) (obtained under Official Information Act 1982 request to EQC) at 3.

458 Acuo, above n 457 at 3.

459 There was a decision on costs on this matter, EQC Action Group v Earthquake Commission [2016] NZHC 1335. This sets out to some extent the factual and the legal background to the dispute.

460 EQC "Joint Statement" <www.eqc.govt.nz>.

461 An example is Pratley Enterprises v Vero Insurance [2016] NZCA 67, [2016] 2 NZLR 750. See also Smith v Claims Resolution Service [2019] NZHC 1013 at [8].

${ }^{462}$ Mediaworks TV v Staples [2019] NZCA 133 at [58], [2020] 2 NZLR 372.
} 
he was acting for the majority of Christchurch earthquake claimants in claims before the High Court. His companies funded some of the costs while charging clients for certain steps in the claims process. On the information before us his companies would take by way of a commission a percentage of any amount recovered. It is said that $\mathrm{Mr}$ Staples claimed to be the Robin Hood of Christchurch.

But not everyone thought that the claims advocates were Robin Hoods. The Toomey Finn research paper describes the advocates as people who would "flock to the scene of disaster in the hope of securing a share of the insurance or settlement monies available". ${ }^{463}$ Taking a share of the insurance payment meant that owners were left short for the repairs. The official Report of the Public Inquiry into the Earthquake Commission pointed to advocates being a major issue: ${ }^{464}$

There is a major issue with the influx of advocates, particularly where they are unqualified and therefore not able to be regulated by the New Zealand Law Society. In many instances they have aggravated the dispute, added substantially to costs and over-promised outcomes for claimants.

Treasury formed a similar, negative view of advocates saying they "made matters worse for the claimants and took money needed to repair homes". ${ }^{465}$

Some insurance companies and lawyers were of the view that the advocates' involvement detracted rather than assisted in resolving the claims, and that sometimes claims were jeopardised and delayed due to the advocates' interference, aggressive tactics, and overinflating of quantum. ${ }^{466}$

\footnotetext{
${ }^{463}$ Toomey Finn research paper, above n 26 at 212.

${ }^{464}$ Cartwright, above $\mathrm{n} 278$ at 15.

465 Treasury, above $\mathrm{n} 454$ at [42].

${ }^{466}$ Interview with DLA Piper; Interview with Young Hunter; Interview with Residential Risk Analysis; Toomey Finn research paper, above n 26 at 212.
} 
Courts were also unimpressed with some of their approaches. In Prattley Enterprises $v$ Vero Insurance ${ }^{467}$ an American loss adjuster ${ }^{468}$ acted as an advocate for the owners and then as an expert in the Court proceedings that followed, and that he had financed. The Court found he had a "powerful financial interest in his evidence being accepted" 469 and therefore his evidence was unreliable. In that case, the plaintiff wanted to undo an earlier settlement agreement seeking a payment ten times more than it originally settled for.

In 2019, at the time of writing the thesis, a group of Canterbury homeowners has started a representative action against one of these advocate providers. ${ }^{470}$ They claim breach of fiduciary duty and unconscionable bargain and being dissatisfied with the advocate's services. In 2021, the case was still going through the courts to determine the parameters of the class action.

\section{Disputes related to interpretation of insurance policies}

The Canterbury earthquake gave rise to many disputes between insurance companies and policyholders on how to interpret the policy terms. The large number of litigated claims led to the High Court establishing a special "Christchurch Earthquake List" to manage litigation resulting from the Canterbury earthquakes. ${ }^{471}$ As of June 2021, the List recorded over 1,300 cases. $^{472}$

There were a wide range of disagreements. There were disputes about the relevance of the red zoning of land; ${ }^{473}$ limitation periods for claiming under the insurance policy; ${ }^{474}$ the

\footnotetext{
${ }^{467}$ Prattley Enterprises $v$ Vero Insurance, above $\mathrm{n} 461$.

468 George Keys of Risk Worldwide New Zealand Ltd.

${ }^{469}$ Prattley Enterprises v Vero Insurance, above n 461.

${ }^{470}$ Smith v Claims Resolution Service, above n 461.

${ }^{471}$ Canterbury Earthquake List, above n 28.

${ }^{472}$ Canterbury Earthquake List, above n 28.

473 O'Loughlin v Tower Insurance [2013] NZHC 670, [2013] 3 NZLR 275.

${ }^{474}$ Inicio Ltd v Tower Insurance [2020] NZHC 90.
} 
application of the Sum Insured in case of successive losses; ${ }^{475}$ joint review of experts; ${ }^{476}$ about the standard of reinstatement of the properties; ${ }^{477}$ appropriateness of repair methods $;{ }^{478}$ how to calculate what is payable under a Full Replacement policy; ${ }^{479}$ whether the Sum Insured was inclusive or exclusive of EQC cover; ${ }^{480}$ obligation to pay indemnity value prior to reinstatement; ${ }^{481}$ whether rebuild costs include professional fees; ${ }^{482}$ and who is responsible for defective repairs. ${ }^{483}$ These are just a few of the cases that were heard before the Courts. I mention other cases throughout the thesis.

The disputes with the insurance companies led to delays in resolving claims while the policy interpretation issues were resolved.

In June 2019, a specialist authority was established, the Canterbury Earthquakes Insurance Tribunal. ${ }^{484}$ Located in Christchurch, the Tribunal aims to resolve Canterbury earthquake insurance disputes in a fair, speedy, flexible, and cost-effective way. ${ }^{485}$ The cases cover a wide range of disputes including disputes about scope of work, ${ }^{486}$ defective repairs, ${ }^{487}$

\footnotetext{
${ }^{475}$ Moore v IAG New Zealand [2020] NZCA 319; Ridgecrest v IAG New Zealand, above n 315; Mathieson v Tower Insurance [2020] NZHC 136; QBE Insurance v Wild South Holdings, above n 330.

${ }^{476}$ Kristinsson v Southern Response [2017] NZHC 456.

${ }^{477}$ Myall v Tower Insurance, above n 314; Body Corporate $335089 v$ Vero Insurance New Zealand and Body Corporate 341154 v Vero Insurance New Zealand [2020] NZHC 2353.

${ }^{478}$ Young v Tower Insurance, above n 345; O'Loughlin v Tower Insurance, above n 473; Rout v Southern Response [2013] NZHC 3262; Parkin v Vero Insurance New Zealand [2015] NZHC 1675.

${ }^{479}$ Tower Insurance v Skyward Aviation 2008, above n 315; Southern Response v Avonside Holdings [2015] NZSC 110, [2017] 1 NZLR 141.

${ }^{480}$ Zurich Australian Insurance v Body Corporate 398983 [2013] NZCA 510.

${ }^{481}$ TJK (NZ) v Mitsui Sumitomo Insurance, above n 330; Medical Assurance Society v East, above n 322.

${ }^{482}$ McLean v IAG New Zealand [2013] NZHC 1105.

${ }^{483}$ Dewes \& ors v IAG New Zealand Ltd \& ors [2019] NZHC 2270; Self-Realization Meditation and Healing Centre v IAG New Zealand \& ors [2019] NZHC 763; Robin v IAG New Zealand [2018] NZHC 1464; Evans $v$ IAG New Zealand [2020] NZHC 1326; Sleight v Beckia Holdings \& ors [2020] NZCH 2851; Bruce \& ors v IAG New Zealand [2019] NZCA 590.

${ }^{484}$ Through the application of the Canterbury Earthquakes Insurance Tribunal Act 2019.

485 <www.justice.govt.nz/tribunals/canterbury-earthquakes-insurance/about-the-tribunal/>.

${ }^{486} M \& M v$ IAG New Zealand [2019] CEIT 0047.

${ }^{487} G$ v EQC [2021] CEIT 0010; E\&E v IAG New Zealand [2019] CEIT 0013.
} 
extent of damage, ${ }^{488}$ process of insurance contract, ${ }^{489}$ fraudulent or invalid claims ${ }^{490}$ and others. These disputes are not specific to multi-unit buildings, but they are mentioned here to point out that the need to establish a specialist tribunal nine years after the earthquakes is evidence that there are still a number of disputes to be heard.

\section{Psychological factors}

The final general issue that affected claims in Canterbury was of a psychological nature. In May 2011, the Chief Science Officer to the Office of the Prime Minister and Cabinet presented a briefing paper on the likely psychological effects of the earthquakes. ${ }^{491}$ This referred to four emotional stages of disaster recovery, similar to the steps recognised in other literature on the issue. ${ }^{492}$ According to the briefing paper and to the specialist literature, the first emotional stage of recovery is the Heroic Phase. This phase occurs directly after a disaster, when people act heroically to save themselves and others. The second is the Honeymoon Period. This lasts from one week after the disaster to around six months. In this phase people come together as a community and feel drawn to help each other and be kind. This phase is marked by feelings of optimism as people see help coming. The third phase is the Disillusionment Phase. This could extend to a couple of years after a disaster. In this phase, the kindred spirit is lost, people begin to get frustrated by the delays and to focus on themselves. People are getting tired and exhausted, and feeling angry and

\footnotetext{
${ }^{488} G \vee$ EQC and Vero Insurance [2021] CEIT 0056.

${ }^{489} \mathrm{~W} v$ Southern Response [2020] CEIT 0020.

${ }^{490} L \& M v E Q C$ [2019] CEIT 0036.

${ }^{491}$ Peter Gluckman The psychological consequences of the Canterbury earthquakes: A briefing paper (Office of the Prime Minister and Cabinet Advisory Services, online ed, 10 May 2011) <www.pmcsa.org.nz/wpcontent/uploads/Christchurch-Earthquake-Briefing-Psychosocial-Effects-10May11.pdf>.

${ }^{492}$ Australian Institute of Professional Counsellors "Common Stages of Disaster Recovery" (26 May 2014) Counselling Connection <www.counsellingconnection.com>. Similar stages are mentioned in Deborah J DeWolfe Training Manual for Mental Health and Human Service Workers in Major Disasters (2nd ed, Education Resources Information Center, 2000) <www.hsdl.org> at 5; Kami Huyse "Crisis Management: The Four Emotional Stages of Disaster" Zoetica (online ed, 23 March 2007) <www.zoeticamedia.com>; Substance Abuse and Mental Health Services Administration "Phases of Disaster" <www.samhsa.gov>; John Bridgeman "The Future City of Christchurch" (paper presented at New Zealand Insurance Law Association conference, Queenstown, 20 September 2018).
} 
disillusioned. Finally, is the Reconstruction Phase. This could last for a few years. People are starting to accept personal responsibility for their situation, start to overcome obstacles and delays, and move toward resolution. This phase is still dominated by negative feelings and reactions.

What these factors show is that people become less cooperative as time goes on. Given the successive nature of the damage in the Canterbury earthquakes, most insurance claims could not be properly assessed until 2012, which would put them in the middle of the Disillusionment Phase. When speaking to a loss adjuster, he observed that while right after the earthquakes, people were happy to collaborate and to arrive to a resolution, two years after the earthquakes, they had become hardened and angry and therefore more difficult to deal with. ${ }^{493}$ Similar comments were made by others involved in resolving multi-unit building claims ${ }^{494}$ and also noted in the Report of the Public Inquiry into the Earthquake Commission: 495

The response to the Canterbury earthquakes was marked by a strong sense of community support. Neighbours, friends, families and extended communities helped each other. However, after the initial emergency response, there were growing feelings of abandonment by agencies that people expected to help them and desperation about longer-term recovery.

In addition, people had difficulty in making decisions as time went on, due to a fear of being disrupted again: ${ }^{496}$

[In] disaster recovery it's a known phenomenon that when you get 3-5 years into the recovery process people get to the point where they can't make decisions. Those who had broken homes, but they've lived in them for so long, didn't want to be disrupted again by having to move out. And we'd get people all the way through to the contract

\footnotetext{
${ }^{493}$ Interview with Nine Dots.

${ }^{494}$ Focus Group discussion.

${ }^{495}$ Cartwright, above n 278 at 101.

${ }^{496}$ Interview with Residential Risk Analysis.
} 
signing and they'd not sign that piece of paper, pen in hand, they couldn't bring themselves to do it because their life would be disrupted again.

It is no doubt that the Canterbury earthquakes have shaken New Zealand to the core. They were devastating. They also brought into focus a number of insurance issues that have not been considered before. The numerous court decisions already mentioned throughout the thesis are a testament to that.

In addition to the general issues affecting all claims in Christchurch, there were several matters specific to multi-unit building claims. I have mentioned some of them in the Introduction and throughout the chapters but now I discuss them in detail.

\section{B Findings Specific to Multi-Unit Buildings}

There were several factors that affected resolution of insurance claims, sometimes applying cumulatively. The thesis divides them into two categories: human issues and technical issues. The human issues are a manifestation of the decision dependencies. And the technical issues reflect the repair dependencies.

\section{The Human Element}

The overwhelming majority of those I spoke to emphasised that the primary difficulty in resolving multi-unit building claims were the people. One insurer recalled:497

It became clear that we had a particular issue with cross-lease property. People started to ask questions, and nobody really knew the answers. What do we do with these properties? We know how to fix our clients' house and we can't do this without touching the neighbours' party walls because they were shared.

\footnotetext{
${ }^{497}$ Interview with Vero Insurance.
} 
Then the MBIE guidelines came out to deal with cross-lease properties. There were two, three versions of that, what were acceptable solutions. Of course, they were only dealing with the technical elements of it. But what was making them difficult and turned them into a nightmare were the actual customers.

Others said the same.

[T] he thing that stopped reinstatement most of the time [was] the human factor. ${ }^{498}$

the thing that swings on everything is the individuals, the people aspect to this type of stuff. So, whether there would be a cross-lease, unit title, whatever, people react differently to different things. So, it's not necessarily legal stuff that's complex but it's how do we manage the people. ${ }^{499}$

So, what does this human factor mean? It means a number of things and can be broken down into six aspects.

1. Lack of understanding of ownership structure.

2. Lack of consensus.

3. Mental illness and vulnerability.

4. The domino effect.

5. Assignment and on-selling.

6. Underinsurance and non-insurance.

\section{Lack of understanding of ownership structure}

The first aspect of the human element is the lack of understanding of ownership structure. Cross-leases are difficult to understand. The research revealed that most of the cross-lease

\footnotetext{
${ }^{498}$ Interview with Residential Risk Analysis.

${ }^{499}$ Interview with RAS.
} 
property owners did not understand the type of property structure they owned. ${ }^{500}$ In addition, most were unaware of their lease obligations or that a lease even existed. One interviewee said: ${ }^{501}$

$[\mathrm{H}]$ and on heart of the thousands of people we dealt with, no one knew about the Memorandum of Lease. No one had even heard of it as a document, it was extraordinary. I mean I certainly didn't know about it, I lived in a cross-lease my first three houses and I had never heard of the Memorandum.

[We] found that people could not get their heads around that they did not own their flat, they just could not comprehend that. We had almost daily sit down conversations with our clients to go through the title and diagram, the comprehensive title and diagram, to explain how it worked. And we would highlight things in the Memorandum of Lease for them to go and consider, and these people were shellshocked. Some of these people had been in their homes for 30-40 years, they had no appreciation that other people have a say in what happens to their flat.

The government created an innovative service called the Residential Advisory Service (RAS) to help homeowners who were having difficulties with their insurance claims. RAS assisted hundreds of cross-lease property owners. RAS found that out of nearly a thousand cross-lease owners they assisted, only one owner was aware of the Memorandum of Lease. ${ }^{502}$ The widespread lack of knowledge was surprising. ${ }^{503}$

\footnotetext{
500 Online survey insurance companies (Emma Gabor, Wellington, 22 January 2018); Interview with Residential Risk Analysis; Interview with specialised contractor with RAS; Interview with DLA Piper.

${ }^{501}$ Interview with Residential Risk Analysis.

${ }^{502}$ Interview with specialised contractor with RAS .

${ }^{503}$ I interviewed two homeowners, but both were aware of the Memorandum of Lease. Homeowner 1 purchased the flat after the 4 September 2010 earthquake so at a time where insurance issues, assignment of claims and owners' responsibilities were top of mind for conveyancers. Homeowner 2 purchased the flat three years prior to the earthquakes, and he said his lawyer took the time to explain the obligations to him.
} 
Like I said in Chapter II, cross-leases are composite titles with two elements: one that refers to the freehold estate in relation to the land ${ }^{504}$ and another that refers to a leasehold estate in relation to the buildings. This appears to have caused confusion: ${ }^{505}$

We had this thrown in our faces all the time, I'm not on a cross-lease, I'm on a fee simple, here's the title that proves it. Every title has a banner and it's either freehold or leasehold and majority are on fee simple because it's freehold land, but the crosslease title has a second banner and it says leasehold.

The owners did not understand the requirements set in the Memorandum of Lease, or the implications of someone being underinsured or uninsured or selling their flat and assigning the claim. ${ }^{506}$ The owners were really linked to each other more than they knew, and this came as a shock to them, the realisation that they were in the hands of their neighbours.

It got to a point where insurers had to get lawyers to meet with the homeowners and explain to them what their lease obligations were. ${ }^{507}$

Those acting for homeowners similarly believed that a lack of understanding of title obligations led to delay and complications in resolving claims. Below is an excerpt of an interview with a lawyer who acted only for homeowners: ${ }^{508}$

Question Let's just go cross-lease properties first. What do you think from the homeowners' perspective were the major impediments or obstacles resolving these claims?

Answer What the problem is, purely, that owners do not understand what their obligations are over the cross-lease.

\footnotetext{
504 Or leasehold estate if the underlying land is leased.

505 Interview with Residential Risk Analysis.

506 Interview with Vero Insurance. See also Online survey of insurance companies, where one respondent answered that the top issue that affected the resolution of multi-unit building claims was that the owners were not aware of their cross-lease obligations to each other regarding reinstatement. Another respondent thought that there were differences in what the owners wanted to do which seems to indicate a lack of understanding of what they were required to do.

${ }^{507}$ Interview with DLA Piper.

${ }^{508}$ Interview with Grant Shand Barristers and Solicitors.
} 
Essentially you have to insure, and if you have insurance money, you have to spend it on restoring the property, which a lot of people haven't done.

Another said the same:509

The classic problem [was] the mismatch between what homeowners wanted to do, even though the cross-lease document itself is pretty clear. I've never seen one that doesn't say you're obliged to repair or reinstate. The fact is that in reality many owners wanted to take the cash, and either do some repairs or do no repairs at all, and sometimes take the cash - for good reasons - take the cash and buy something else and sell their damaged home for somebody else to worry about.

Where the owners did not know or did not understand their obligations under the crosslease, there was a risk that they would default on their obligations, for example the obligation to insure, the obligation to apply the money toward reinstatement, and the obligation to update the cross-lease title when making alterations to the building. Where a breach happened, the consequences of the breach affected the other owners in the development.

Understanding the property title did not seem to be a problem for large Body Corporates. Owners had at least a basic understanding that they were part of a community of owners. This is likely to be a result of apartment ownership being more widely known, possibly due to the due diligence and disclosure obligation when apartments are being purchased.

An exception was small Body Corporates. Small Body Corporates have no obligation to establish a Body Corporate Committee. ${ }^{510}$ Where there is no Committee, no one oversees compliance with the UTA. Some of the small Body Corporates were dysfunctional and this led to complicated claims, as detailed later in the chapter. ${ }^{511}$

\footnotetext{
${ }^{509}$ Interview with Lane Neave, Law firm, (Emma Gabor, Wellington, 10 April 2018).

${ }^{510}$ UTA, s 112(1).

${ }^{511}$ Interview with specialised contractor with RAS.
} 


\section{Lack of consensus}

The second aspect of the human element was the lack of consensus between the owners. Owners were unable to reach consensus for a variety of reasons, but I mention five here.

\section{Poor neighbour relationships}

The first reason owners had difficulty reaching consensus was the poor relationships between them. In some cases, the relationships broke down completely. Some neighbours had trespass orders against each other and insurers had to have meetings where they "had security, to stop people coming to blows". ${ }^{512}$ It is possible that the poor relationships were exacerbated by the trauma caused by the earthquakes and the inevitable move through the Disillusionment Stage of the recovery period.

Sometimes neighbours had a prior relationship that had gone bad: $:^{513}$

It might have been a boyfriend and girlfriend who purchased flats side by side and then the relationship has ended ... the ex is a bit sour and refuses access to the property ... it becomes impossible to assess the building as a whole.

In the online survey, the insurance companies responded that one of the top three issues that held back resolution of multi-unit building claims were neighbour disputes and differing personalities among the owners. ${ }^{514}$

The media reported some cases as well. An article in 2017 presented the story of a couple whose cross-lease flat could not be rebuilt. ${ }^{515}$ The couple recounted how the earthquake-damaged cross-lease "ruined their life". The article talked about various

\footnotetext{
512 Interview with Residential Risk Analysis.

${ }^{513}$ Interview with lawyer (Christchurch, July 2016) cited in Toomey Finn research paper, above n 26 at 20.

${ }^{514}$ Online survey insurance companies.

${ }^{515}$ Small, above $\mathrm{n} 9$.
} 
failures of the rebuild process, including a fall-out between the neighbours that led to the reinstatement work being abandoned.

Another article included comments from the readers with one presenting a "toad" of a claim involving a Body Corporate that was unable to function adequately: ${ }^{516}$

Many of the long tail of claims are the very knotty ones, e.g. multi-unit properties. Consider a block of six flats, all in a row. There was a body corporate, which theoretically could have insured everyone under one policy. It met four times, the last 15 years ago. Between all of the six units, there are four insurers. The owner of Unit 4 died intestate 2 years ago. The owner of Unit 1 is overseas, permanently. The owners of units 5 and 6 communicate only via their lawyers despite living 2 metres apart.

There has been no feedback in relation to relationships within a company share scheme for claims arising out of the Canterbury earthquakes, but case law shows that poor neighbour relations can also impact reinstatement of a company share building. In Davy $v$ Scarrott ${ }^{517}$ the directors of a company share scheme in Wellington wanted to impose levies for replacement of the windows and balcony balustrades. Some owners challenged the validity of the levies proposed. It appears that one of the owners was only opposing the proposal to put pressure on the directors so they would allow him to keep a dog in the apartment. ${ }^{518}$ Legal costs had to be incurred to resolve that dispute. So, personal issues can interfere with proposals related to the maintenance of the building. This shows that multi-unit buildings are more than just buildings; they are communities of people. And people sometimes have different interests and priorities or cannot get along.

\footnotetext{
${ }^{516}$ Cameron Preston "Cam Preston says many Christchurch residents still have good reason to 'carp \& moan' five years on from the first earthquake" Interest (online ed, 3 September 2015).

${ }^{517}$ Davy v Scarrott, above n 114.

${ }^{518}$ Maarten Hall “Court Doesn't Hold Key to Dorchester Apartments Deadlock - Judge” Stuff (online ed, 8 August 2016).
} 
If there are poor relationships between the owners, this will prevent good decisionmaking. One article put it well: ${ }^{519}$

You can't pick your neighbours. You may not even like them. But when you own a property in a unit title development (as opposed to a fee simple or cross-lease title), you and your neighbours are covered by the same insurance policy. [...] To get a result, all owners must ultimately work together and agree on the final method of payment. Compromises may be needed so that all owners [sic] on board. The last thing you want is for some owners effectively "holding out" - which results in everyone suffering.

Multi-unit buildings are characterised by decision dependencies. It is therefore imperative there is a working relationship between the members of the multi-unit building to make decisions on management of the insurance claim.

\section{Absentee owners}

The second reason owners were sometimes unable to reach consensus was simply that some owners were absent. This did not appear to be problem for Body Corporates 520 because they were required to keep a register of owners, but was mostly a problem for cross-lease properties. ${ }^{521}$ It was difficult for the other owners in the cross-lease development to locate and contact them, especially if they lived overseas. ICNZ pointed out that the problem with cross-leases is that they require 100 per cent consensus between the owners, so it is imperative to locate all owners, which is sometimes difficult. ${ }^{522}$

Again, it comes back to the need to secure consensus. And if owners are absent, the others need to make additional efforts to locate them and secure their consent.

\footnotetext{
${ }^{519}$ Land and Ballinger, above $\mathrm{n} 17$.

${ }^{520}$ Unless they were dysfunctional and had not complied with the requirement to keep a register of owners.

${ }^{521}$ ICNZ "Canterbury Earthquakes" <www.icnz.org.nz>. Toomey Finn research paper, above n 26 at 83 also mentions absentee owners as being a difficulty.

${ }^{522}$ ICNZ "Canterbury Earthquakes" <www.icnz.org.nz>.
} 


\section{Many parties, different interests}

The third reason it was difficult to get consensus was that not everyone had the same priorities. For cross-lease properties and fee simple townhouses, there were simply too many decision-makers and there was no governing body to get a coordinated response.

EQC raised this point at the Focus Group discussion. Talking about the major problems in resolving multi-unit building claims, EQC listed the following: ${ }^{523}$

multiple insurers, complexity of repair, just much more difficult when you have a number of dwellings in one building. Personality of owners, and multiple people, just the fact that you are dealing with multiple people, getting them to agree.

Hon Gerry Brownlee MP, the minister responsible for the earthquake recovery at the time, reported similar issues to Parliament: ${ }^{524}$

I know ... one case in Christchurch [involving] 43 units in that structure, with 13 different insurers alongside the Earthquake Commission, sometimes it is difficult to sort those things out.

RAS echoed the frustrations: ${ }^{525}$

[The] biggest constant [is] the variability of humans. And I don't mean just title holders or policyholders. I might be dealing with two or three different lawyers giving advice, or two or three policyholders, or an advocate and two lawyers. They are part of the human aspect. There could be an engineer or two engineers, four sons and two daughters, it is not just the title policyholder. It is also trying to get everyone to buy in and not try to score for the benefit of the title policyholders. So, it is that big human bubble in the middle of the technical and legal side of things.

\footnotetext{
${ }^{523}$ Focus Group discussion.

524 (2 July 2014) 700 NZPD 19128.

${ }^{525}$ Interview with specialised contractor with RAS; Online survey ICNZ (Emma Gabor, Wellington, 22 January 2018).
} 
This illustrates the deeper level of the human element and the possibility of sub-layers of decision dependencies. An owner might be taking legal advice or might have an advocate making decisions for them. Insurers might be influenced by recommendations made by experts. It shows the extensive interrelationships between the owners, their advisers and insurers.

A number of interviewees mentioned issues with landlords. ${ }^{526}$ Some wanted to take the cash and invest somewhere else rather than wait for a repair. One interviewee said:527

The interesting thing about multi-unit dwellings is that many of them are owned by absent landlords or by people of very modest means and there is a real mismatch. So you've got a retired person who's [a] freeholder of a modest unit and hasn't got the resources to fight it, and yet the next one is held by an absentee landlord who actually has only got one focus, and that is how much wealth can I extract from this unit in the long term.

The divide between the interests of a landlord versus that of an owner-occupier was clear to one homeowner: ${ }^{528}$

The people who were not keen on the rebuild were the landlords and that's because they were looking at how much loss of rent time they had versus what is a realistic rebuild time. And I think that's when they were crunching the numbers and going 'rebuilds are not quick at the moment, it's going to take far too long, and I'll be out of pocket'. Whereas for me I could go and stay with family, so I'd be happy to wait.

This highlighted the difference in interests between the owners. There was no way to coordinate a response, and, in some cases, cross-lease and fee simple owners could not be forced by a majority vote. This gave cross-lease and fee simple owners immense powers.

\footnotetext{
${ }^{526}$ Focus Group discussion; Interview with Lane Neave; Interview with Homeowner 2; Interview with specialised contractor with RAS; Interview with Residential Risks Analysis.

${ }^{527}$ Interview with Lane Neave.

${ }^{528}$ Interview with Homeowner 2.
} 
EQC revealed some complications with fee simple titles: ${ }^{529}$

The issue where they share a common element becomes very complicated especially if you are trying to enforce repairs on your neighbour to get your building repaired.

So there have been situations where that has caused quite a bit of challenge for us I think. We were quite lucky that are was an easement on the firewalls with this particular freehold so we were able to use that to force the neighbouring property [owner] to agree to a joint repair.

EQC's experience was not singular. A lawyer recounted one of his cases involving four fee simple townhouses. ${ }^{530}$ They adjoined each other, and they had a common concrete foundation slab. There was an easement regulating the obligations of the parties in relation to the common elements of the building. Unit 2 owners sold the unit in a damaged state to a builder who was planning to repair the flat himself. When the insurers of the other three units concluded that the units were uneconomic to repair and had to be demolished and rebuilt jointly, the purchaser of Unit 2 refused. At the time I interviewed the purchaser's lawyer, the parties were preparing to go to arbitration. I followed up a year or so later to see what the outcome was. The parties were not able to agree, and the arbitration was adjourned part-heard. In the end, the purchaser/builder agreed to sell his unit to another unit owner to enable the rebuild to proceed. The disagreement took two years to resolve, and in this time, the insurance claims could not be resolved.

RAS also encountered difficult situations with fee simple townhouses where there were common walls and no easements, or where easements were insufficiently drafted. ${ }^{531}$ They had a case where owner A owned three of four units in a fee simple development. Owner B owned Unit 2. The advice from the engineer was that the units had to be re-levelled. This involved lifting the foundations to match the original level. Owner A did not want to re-

\footnotetext{
${ }^{529}$ Interview with EQC.

${ }^{530}$ Interview with Young Hunter. Young Hunter was acting for the purchaser of Unit 2.

${ }^{531}$ Interview with specialised contractor with RAS.
} 
level her units. There was no easement to set out the parties' obligations and there was no easy way to force owner A to yield up the insurance money for repairs.

RAS' view was that fee simple townhouses with no easements on the party walls were "the worst" 532 because there was little or nothing you could do to force a fee simple owner to do something to their property. This comes back to the underlying title. A fee simple owner is free to leave the property unrepaired if they want to, unless there are covenant obligations, or the property creates a hazard to others.

And owners are not the only parties that have a say in relation to their properties. As mentioned before, insurers also are decision-makers in relation to claims. Thus, in addition to coordinating many owners, for cross-lease properties, fee simple townhouses, and unit titles insured independently, insurers also needed to reach consensus between themselves in relation to the repair methodology. This created a double-decision dependency.

Further, banks also have a say in what happens to the insurance proceeds for cross-lease properties and fee simple townhouses. Sometimes, the banks required the money to be used in payment of the mortgage and refused to lend for the reinstatement work. ${ }^{533}$

So there were many parties involved in making decisions in relation to a claim and there was not always commonality of interest.

By way of illustration, below is a diagram that visually represents the interrelationships between the parties. The first diagram shows the relationships within a Body Corporate or a company share schemes. Owners make decisions within the boundaries or "bubble" of their governance structure. There is only one insurance policy, which means there is only one EQC claim and only one private insurer involved. The bank does not have a say in what happens to the money (if the Body Corporate applies it toward reinstatement).

\footnotetext{
${ }^{532}$ Interview with specialised contractor with RAS.

${ }^{533}$ Interview with Homeowner 2.
} 
Image 1 - Canterbury model - Body Corporates and company share schemes

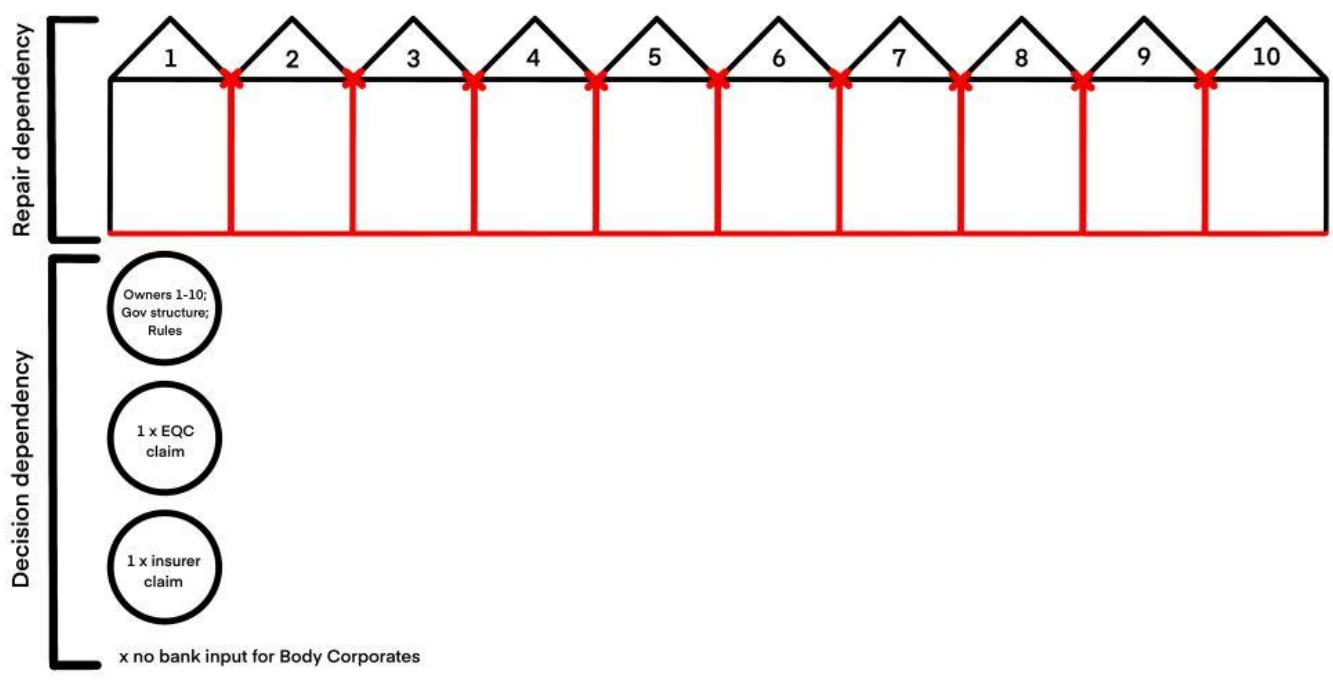

This is to be contrasted with the situation applicable to cross-leases and fee simple townhouses. There are many owners, each seeking to make decisions independent of each other. Units are insured separately meaning there are multiple insurance claims, both with EQC and with the private insurers. The bank has a right to direct how the insurance payment is used. The diagram shows the extensive interrelationships between the parties within a cross-lease or a fee simple townhouse development. I return to these points in chapter VI.

Image 2 - Canterbury model - Cross-leases and freehold townhouses

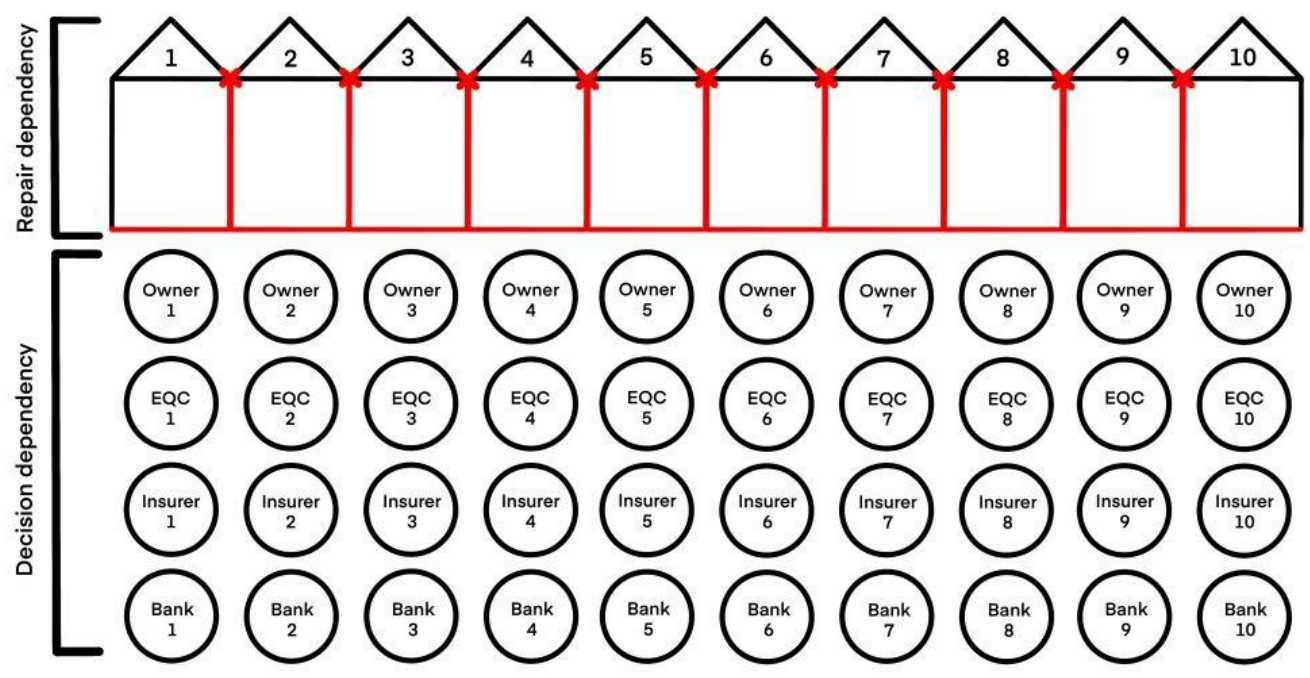




\section{No coordinated response}

The fourth reason owners were unable to reach consensus was that there was no common forum for making decisions. For cross-lease properties and fee simple townhouses, there was no governance structure and no pre-determined decision-making process. Owners were reluctant to engage, poorly informed about their rights and obligations.

This contrasts with Body Corporates, where there was a Committee and a process for making decisions established through legislation. Body Corporates managed better in this regard. It also helped that Body Corporates were generally insured under one policy, as that meant there was only one insurer involved. ${ }^{534}$ This significantly reduced the number of decision-makers and enabled a more efficient exercise of the decision dependency.

Company share schemes are similar to Body Corporates in this regard. There is a predetermined way of making decisions established by the company's constitution. There is a governance structure in the form of a Board of Directors that exercises a tight control over the property and what happens with the insurance claim. Everything that is fixed (even if related to just one unit or is cosmetic damage) is deemed to be related to the building, and therefore under the control of the Board rather than the individual owner. ${ }^{535}$ However, it seems that the Directors still face internal issues in getting owners to agree. While they have the right to veto and decide on behalf of a unit owner, they often try to get consensus. ${ }^{536}$

While claims for large Body Corporates were easier to manage due to the governance structure in place, the situation was not so good with small Body Corporates. Some small Body Corporates did not function well. Sometimes, property owners did not know they belonged to a Body Corporate. ${ }^{537}$ These owners usually insured the units themselves and dealt with the insurance money as they pleased. Some of them did not apply the insurance

\footnotetext{
${ }^{534}$ Interview with Young Hunter; Interview with Grant Shand Barristers and Solicitors; Interview with Lane Neave.

${ }^{535}$ Interview with Roger Phillips.

${ }^{536}$ Interview with Roger Phillips.

${ }^{537}$ Focus group discussion; Interview with Grant Shand Barristers and Solicitors.
} 
money toward reinstatement, which led to problems for the other unit owners. RAS also found situations where the owners were in breach of the UTA. ${ }^{538}$

EQC recounted issues with dysfunctional Body Corporates: ${ }^{539}$

We did have situations where there were multiple unit title owners upwards of ten with no Body Corporate structure in place which makes it very challenging with complexities that what you would have with a cross-lease. In that situation ... if there is an issue, it becomes a civil dispute between the owners instead of an insurance dispute. We can only respond to the damage, we don't get too involved in the legalities of a dysfunctional Body Corporate. It does create a challenge when we are trying to make payments to one individual owner. For example, if we had a remedial claim come in to us, and the damage only affected one unit owner, in order for us to get payment to that customer if it is a dysfunctional Body Corporate that is not operating Body Corporate, some of them don't even have a bank account. This makes it difficult for us to get payments or funds to that particular customer so what we would have to do is get in writing an agreement from the rest of the owners that they are happy for funds to be paid to that owner. Because for us the insurance policy is with the Body Corporate and not the individual owner.

Where there was no coordinated response, it was more difficult for insurance companies to liaise with multiple owners, and progress claims.

\section{Disagreements on how to proceed}

The fifth reason for the difficulty of reaching consensus is that there were internal disagreements on how to proceed. I noted above that owners had different interests and agendas, and this led to deadlocks on how to proceed. The fact that there was a governing body and a way of making decisions did not always spare a Body Corporate from internal disagreements. Sometimes these would surface during an insurance claim: ${ }^{540}$

\footnotetext{
${ }^{538}$ Interview with RAS.

${ }^{539}$ Interview with EQC.

${ }^{540}$ Interview with Young Hunter (which was acting for the insurer in the claim).
} 
I've got one of the claims I'm dealing with at the moment where there is, I'm told, quite a bit of friction and fighting between the Body Corporate unit owners, no one can reach agreement. You've got some of the unit owners who are displaced and no longer able to live in their home - they want to get some money and they want to buy a new unit or a new home but they can't get the money because the Unit Titles Act provides that the Body Corporate has to apply the insurance money in reinstatement of the building unless the Body Corporate decides otherwise at a general meeting.

You've got individual unit owners fighting amongst themselves some of whom want their unit repaired, others want to get a cash payment you know - so really difficult, if not impossible, to work out those issues.

An insurance broker who assisted Body Corporates with their Canterbury insurance claims also observed some disagreements: 541

[The] big thing was the distribution of funds post settlement and how that was to be undertaken. Some people challenged the way it was written within the rules and felt that it should be based on unit size as opposed to the way the rules delineated it. So, you'd have challenges like that but ... more often than not 95 per cent of people were reasonable and it was resolved quite quickly once the settlement sum was paid.

There were media reports about differences of opinion between Body Corporate owners. The Cave Rock apartments in Sumner, Christchurch, are an example. ${ }^{542}$ They comprised 49 residential units and one commercial unit. It was badly damaged in the earthquakes and could not be occupied. The Body Corporate had a long-running dispute with their insurer and EQC, which was reportedly settled at mediation in 2018. The cause of the dispute was not disclosed but there were media reports suggesting that the Body Corporate was underinsured and that the dispute was whether more than one Sum Insured should be

\footnotetext{
${ }^{541}$ Interview with Crombie Lockwood.

${ }^{542}$ Liz McDonald "Waterfront apartment owners at war over splitting insurance payout" Stuff (online ed, 12 January 2019).
} 
paid. ${ }^{543}$ The settlement of the insurance claim was not the end of the road for the owners, however. There was a disagreement between them on how to split the insurance money. While 45 owners were in agreement, five owners disagreed, so the Body Corporate was heading to Court to resolve the disagreements between the owners: ${ }^{544}$

[The Body Corporate head, Mike] White said it was "tragic" issues remained unresolved for the owners eight years after the earthquakes, particularly for the elderly owners and those [11 owners] who died waiting. Some have struggled to fund mortgages and rates while having to find another home.

White said their situation was an example of the deficiencies of Body Corporate law. "Getting unanimous agreement can be impossible, even with a small group of owners. You only have to have one person wanting a bigger share of the pot, and they can hold the rest to ransom. The rest have to decide whether to agree, or else pay more money to go to court."

RAS found that the UTA process was open to abuse, and that there was "potential coercion" within the Body Corporates to achieve their percentages and alienate those who disagreed: 545

[We had some] unbelievably, terrible hard situations which possibly might come up in another doctorate at some stage. Because no-one is auditing or overseeing ... we had some very sad clients in here.

\footnotetext{
${ }^{543}$ Nick Truebridge "Seven elderly residents at Sumner apartments died waiting for settlement" Stuff (online ed, 12 August 2016). The article reported that the apartments had a Sum Insured of $\$ 16,000,000$ but the remedial costs were estimated at $\$ 23,000,000$. As the Body Corporate was not looking to reinstate, the insurer offered only the indemnity value of the building, which was estimated at $\$ 10,000,000$. The Body Corporate argued that it was entitled to full reinstatement cost even if it did not intend to reinstate, and that it was entitled to more than one Sum Insured as the building suffered damage in two aftershocks (February and June 2011).

${ }^{543}$ McDonald, above $\mathrm{n} 542$.

${ }^{544}$ McDonald, above n 542.

${ }^{545}$ Interview with specialised contractor with RAS.
} 
The case of Dominion Finance Group (in Rec and Liq) v Body Corporate $382902^{546}$ involved the Gallery Apartments in Gloucester Street, Christchurch. It comprised 17 residential apartments and one commercial unit. The Court reported that the apartments were well insured. The Body Corporate settled their claim for $\$ 16,859,000.00 .^{547}$ The owners decided to split the money between themselves. This was done based on a valuation assessment as to the value of the apartments in 2007. A few months later, the owners decided to cancel the unit title and split the money based on the 2007 entitlements. In the process of cancelling the unit title, they were required to re-assess the ownership interests. The valuation of the ownership interest was different from the 2007 valuation. This led to a dispute between the owners as to their entitlement, which involved a repayment of about $\$ 1,000,000$ between owners. The dispute could not be resolved, and the owners had to go to court. ${ }^{548}$

A similar case was Mills v Body Corporate $47522 .{ }^{549}$ This was a small Body Corporate of five units. The units were badly damaged in the Canterbury earthquakes and subsequently demolished. The owners settled their claim with their insurer and decided not to rebuild. Instead, they were looking to cancel the unit plan. There was disagreement on the apportionment of the insurance money, which had to go to Court for resolution. ${ }^{550}$

It seems that for Body Corporates issues arose where they were required to achieve a special majority of votes. Of course, the higher the percentage of votes that needs to be achieved, the more power is given to individuals, leading to situations akin to veto powers, which makes it difficult to achieve a collective decision.

\footnotetext{
546 Dominion Finance Group Ltd (in Rec and Liq) v Body Corporate 382902 [2012] NZHC 3325, (2012) 7 NZ ConvC 96-003.

${ }^{547}$ Dominion Finance Group Ltd (in Rec and Liq) v Body Corporate 382902, above n 546 at [16].

548 Dominion Finance Group Ltd (in Rec and Liq) v Body Corporate 382902, above n 546. The Court found that it was just and equitable to leave the share split as per the 2007 entitlements as agreed.

${ }^{549}$ Mills v Body Corporate 47522 [2013] NZHC 1854.

550 Another case was OM Hardware Ltd v Body Corporate 303662 [2015] NZHC 190, (2015) 15 NZCPR 921. In that case the Court noted at [1] that the building was "adequately insured and the owners of the building were indemnified for their loss".
} 
A group of ten cross-lease owners also had to go to Court because they could not agree on what to do with their damaged flats. ${ }^{551}$ In that case, the flats were damaged beyond economic repair. Due to the repair dependencies, the ten units could only be demolished and rebuilt together. The insurers refused to get involved with the rebuild process because some of the owners did not have Full Replacement cover and the source of their funding was uncertain. The owners had to choose between organising their own rebuild or selling to a developer. Most owners wanted to sell to a developer. However, one owner opposed the sale. She had two reasons. First, she thought that the prices would increase, and it was better to hold the properties for a while. Second, she was an overseas purchaser and was afraid that once she disposed of the property, she might not be able to purchase another property in New Zealand. ${ }^{552}$ She asked for a larger share of the sale price to compensate her for that possibility. The owners could not agree and had to go to Court. The Court made an order directing the sale of the flats, noting with concern the deadlock situation the owners found themselves in.

Disagreements between owners stalled the progress of insurance claims or prevented others from moving on and receiving a payment. In 2017, when I was organising a Focus Group discussion, a homeowner approached me, wanting to take part. I had to turn her away because I did not have the University's Ethics approval to interview homeowners at that stage. However, she went on to tell me that she owned an apartment building in Wellington which was lightly damaged in the Kaikoura earthquake. The insurer appointed a loss adjuster who prepared a schedule of loss for each apartment and offered to settle in cash for the cost of reinstatement. She was happy with the assessment and the estimate of costs for her apartment and was keen to proceed, but there were a few other owners who were not happy with their assessments. She said everyone had to wait until the owners who were disagreeing got their assessments sorted and agreed, and that the insurer would not pay the others until everybody agreed. She was disappointed the others could hold up resolution of her insurance claim. It seems insurance companies proceed on the basis that the Body

\footnotetext{
${ }^{551}$ Rozee v Zhang [2019] NZHC 2165, (2019) 20 NZCPR 547.

552 Due to the adoption of the Overseas Investment Amendment Act 2018.
} 
Corporate is the insured/policyholder ${ }^{553}$ and they want to achieve a binding settlement with the Body Corporate, rather than the individual owners.

\section{Mental illness and vulnerability}

The third aspect of the human element exhibited in multi-unit building claims was related to mental illness and vulnerabilities. The online survey of insurance companies revealed there were situations of mental health issues and disability in multi-unit buildings in Canterbury. ${ }^{554}$ Some interviewees arrived at the same view:

Shared construction cross-lease in particular draws the marginalised people of society. Those who've been disenfranchised. You've got the elderly, you've got those who are low socio-economic, uneducated, those who are put into flats by their family because they had mental health issues but they've bought them a little flat so they could sort of be independent. ${ }^{555}$

You've got a spectrum but invariably we would suggest that the majority of people in the multi-unit buildings were probably more vulnerable, elderly ... People that are not financially resourced to support themselves in a legal battle ... vulnerable in some form, either health or age. ${ }^{556}$

It is unclear how widespread this particular problem was. The Toomey Finn research paper also found that there were instances of vulnerability, particularly among the cross-lease

\footnotetext{
${ }^{553}$ Interview with Young Hunter.

554 Online survey insurance companies.

${ }^{555}$ Interview with Residential Risks Analysis.

${ }^{556}$ Interview with specialised contractor with RAS.
} 
owners. ${ }^{557}$ It appears that CERA had a high involvement with cross-lease properties due to perceived vulnerability of the people. ${ }^{558}$ EQC made similar remarks saying that: ${ }^{559}$

[In] the cross-leases ... [a] high percentage of the people were in the lower socioeconomic bracket, were elderly, [and this] just created extra complexity.

The elderly caused concern. They did not have the energy and the drive to go through the remedial process. Some were apathetic about the repairs or simply unwilling: ${ }^{.60}$

[E]lderly people don't actually care. They don't want it fixed because they don't want to be out for a year or so while it is fixed because they might die - they might never get back there or they might be forced into a home.

While it is not an unreasonable position when viewed from an elderly person's perspective, it means that the repairs for the other owners in the development are being held up. A sad example I was given was of a lady who was given three months to live. Understandably, she did not want to go through a repair. What happened in that case was that the remaining owners raised money together to purchase her flat, so she could move away and live the rest of her days in peace, while they went on with the repair process. ${ }^{561}$

In addition, there were instances of paranoia: 562

You had under mental health ... paranoia, extreme paranoia thanks to the media [that] they were being screwed over by the insurance companies.

\footnotetext{
557 Toomey Finn research paper, above n 26 at 21.

${ }^{558}$ Interview with Nine Dots.

${ }^{559}$ Focus Group discussion.

${ }^{560}$ Interview with lawyer, (Christchurch, July 2016) cited in Toomey Finn research paper, above $\mathrm{n} 26$ at page 21.

${ }^{561}$ Interview with specialised contractor with RAS.

${ }^{562}$ Interview with Residential Risks Analysis.
} 
Perhaps too obvious to be stated, the earthquakes themselves caused emotional distress. One homeowner recounted: ${ }^{563}$

The emotional experience of [the earthquakes] was just life changing. Not at the time; you don't feel any different, but you realise later in reflection looking back years later that you were actually traumatised by it, you tensed up to survive and cope.

For some, the stress was compounded by seeing the damage and devastation to their property. One couple had to leave their apartment due to the next-door building being considered unsafe: ${ }^{564}$

So they put the red sticker ${ }^{565}$ and we weren't allowed to go back in the apartment at all.

[T] he people [who] went to check that everyone was evacuated, they actually damaged our property. We had a loft and they just shoved their hand right through and broke all the venetians and left all the windows wide open so we had liquefaction come in. One woman was there saying "Don't break my door down, I'm just getting my keys!” It was terrible, just like cowboys. So that just added stress on stress.

The next day the army arrived and there was a tank outside our apartment pointing a gun up towards.

[It] took 6 months for our neighbours' property to be demolished. What happened to the red sticker? It stayed there for another 12 months. So, we were fortunate because we [bought another place] but other people who had only been given like 12 months' insurance for rent were all used up. So, people were living with friends and the pressures of families together and all that happened because an official did not pull off a red sticker. While they weren't doing anything, they didn't let anyone go in, to close windows or do things like that ... people were very stressed because they couldn't get

\footnotetext{
${ }^{563}$ Interview with Homeowner 1 (Emma Gabor, via Zoom Christchurch / Wellington, 1 June 2020).

${ }^{564}$ Interview with Homeowner 1.

565 This is colloquial name for formal placard forbidding entering or occupying a property deemed unsafe, issued under the Authority of the Civil Defence Emergency Management Act 2002. The placard was coloured red and it became known as a red sticker.
} 
in. Things were being ruined, things were being wrecked, carpets were going mouldy and all that kind of thing.

Insurance claims became more difficult when homeowners were in emotional distress, sick, vulnerable, or elderly.

\section{The domino effect}

The fourth aspect of the human element was the link between the owners created by the repair and the decision dependencies. This created a domino effect where a homeowner's decision had a ripple effect on the other owners. If one cross-lease or fee simple neighbour did not want to repair, this delayed things for everyone else until a solution was found, either by way of legal proceedings or consensus. The same happened in situations where a neighbour sold the flat, or where they died without leaving a power of attorney or where they had a personal crisis such as a divorce. The decision dependency meant that things could not be progressed until everyone consented.

\section{RAS provided some examples: ${ }^{566}$}

I always talk about "the Doris clause". The day before [the owners] were about to sign a building contract, five of them, all elderly, Doris died. She had no power of attorney. And the estate took over and refused to sign the building contract. And that building remains standing now. They all cash settled and were unable to deal with the as-is sale owner.

I've got [another owner who] refused to get a power of attorney in place. We got a contract that they're going through at the moment, he had a stroke two weeks ago. He's still not talking. He is the 100 per cent caregiver for his wife who has advanced dementia ... So, it's the human factor! This is the reality. Now the neighbours, who fell apart over the last two years, the marriage fell apart, I've only just got them to the

\footnotetext{
${ }^{566}$ Interview with specialised contractor with RAS.
} 
point of settlement. So, I've got it all in place but now I can't get the deposit paid [because of the owner who had a stroke] ...

[In] the same example with the stroke, his wife took off with the first [insurance] payment.

These examples show that personal issues could hold up the reinstatement process for an entire multi-unit development. When seen through the decision dependency lenses, it is easy to understand why. Homeowners who experienced personal difficulties or trauma were not able to focus on making decisions. And in those situations when someone died or moved away, they passed the decision-making power to somebody else, but there was usually a time gap until the new owner got up to speed with the rest of the owner community.

Sometimes neighbours did not want to disclose personal things such as their financial position, but their lack of funds affected everyone in the development: ${ }^{567}$

[T] here is often mistrust [between the neighbours] ... We are still hearing at the moment people who are just unwilling to share their financial information with each other and will only do that when it comes to the contract signing. We've spent near hundreds of thousands of dollars on design, then when it comes to the signing of the contract, at the very last minute, an owner might say: 'I have not got the money; I have already spent the EQC payout' ... right at the last minute, absolute devastation for the other owners. ${ }^{568}$

Multi-unit building owners are tied to each other more than they realise and their decisions, even of a personal nature, affect the others.

\footnotetext{
${ }^{567}$ Interview with Residential Risk Analysis; Interview with Nine Dots; Toomey Finn research paper, above n 26 at 86 .

${ }^{568}$ Interview with insurer (Christchurch, July 2016) cited in Toomey Finn research paper, above n 26 at 25.
} 


\section{Assignment and on-selling}

The fifth aspect of the human element relates to assignment of insurance claims and onselling damaged properties. An insurance policy is a personal contract. ${ }^{569}$ That means an insurance policy cannot be assigned or passed on to another. However, once a loss occurs and a claim made, the benefit of the insurance claim can be assigned like a debt, an assignment of an ordinary thing in action. ${ }^{570}$

As mentioned in Chapter III, the benefit of an insurance policy (that is, what the policy pays) can differ according to what the policyholder decides to do. If a policyholder decides to reinstate, they are entitled to reinstatement costs. But if they do not reinstate, they are generally only entitled to the indemnity value of the repairs, or the indemnity value of the building if it is a total loss. This is less than reinstatement costs.

If a policyholder decides to sell the property, they are deemed by implication to have chosen not to repair or reinstate. That means they are not entitled to the costs of repair or reinstatement, only to an indemnity payment. A policyholder cannot assign more than they have themselves. At the point of sale, a policyholder no longer has the right to request a payment of reinstatement costs and therefore cannot assign such right.

The assignment point was tested in Xuv IAG New Zealand. ${ }^{571}$ In that case, the homeowners were insured with IAG at the time of the Canterbury earthquakes. They made a claim on IAG but sold the property before the claim settled and without reinstating the property. The homeowners assigned the claim to the purchaser. ${ }^{572}$ The purchasers wanted IAG to pay full rebuild costs, saying they intend to reinstate. ${ }^{573}$ Legal proceedings followed when IAG

\footnotetext{
${ }^{569}$ Bryant $v$ Primary Industries Insurance Co Limited 2 NZLR 142 (CA); Xu \& Diamantina Trust v IAG New Zealand [2018] NZCA 149 at [11], 20 ANZ Insurance Cases 62-177.

${ }^{570}$ Xu v IAG New Zealand [2017] NZHC 1964 at [36], 19 ANZ Insurance Cases 62-160, citing Schneideman v Barnett [1951] NZLR 301 at 306.

${ }^{571} \mathrm{Xu} \&$ Diamantina $v$ IAG New Zealand, above n 569.

572 The founder of advocacy companies Earthquake Services Ltd and Claims Resolution Service Ltd.

573 The property was purchased for $\$ 217,000$ plus GST. The purchasers sued IAG and EQC seeking full rebuild costs estimated at $\$ 584,000$. See Xu \& Diamantina $v$ IAG New Zealand [2017] NZHC 1964 at [5] and [1].
} 
refused. The High Court held for IAG. The Court of Appeal ${ }^{574}$ and the Supreme Court upheld the decision. ${ }^{575}$ The Court reinforced that the benefit provided under a fire policy is personal to the insured and it is not for the benefit of a third party such as an assignee. ${ }^{576}$

Assignments of insurance claims are difficult to understand. They appear to have been misunderstood at the time of the Canterbury earthquakes. A case on point is Doig $v$ Tower Insurance, ${ }^{577}$ where $\mathrm{Mr}$ and Mrs Doig purchased an earthquake damaged house for $\$ 1.155$ million on the back of an advertisement that boasted that the deal would "allow the purchasers to pursue and profit from a potential rebuild" and that "forward thinking purchasers [would] reap the rewards and benefits of a full potential rebuild". ${ }^{578}$ At the time of the sale, in October 2012, it was uncertain whether the repair cost would exceed the EQC cap. The Doigs made inquiries with Tower before committing to the purchase. They thought that Tower was going to cover them on a Full Replacement basis for any existing damage. Four years later, the engineers advised that the property was a total loss. Tower paid the Doigs $\$ 583,090$ on an indemnity basis. ${ }^{579}$ The Doigs issued proceedings claiming they were entitled to full rebuild $\operatorname{costs}^{580}$ and claiming estoppel against Tower. The Court held for Tower.

Both $X u$ and Doig show that owners, real estate agents, and conveyancing lawyers misunderstood what could be assigned.

In an interview with a homeowner, a similar story of misunderstanding emerged. This homeowner and his mother each owned a unit in a cross-lease development. His mother sold the flat, and her solicitor duly prepared a deed of assignment. The purchaser's solicitor did not know what the assignment was for and advised the purchaser not to sign the deed of assignment. Five years later, when the property was declared a total loss, the purchaser

\footnotetext{
${ }^{574}$ Xu \& Diamantina v IAG New Zealand, above n 569.

${ }^{575}$ Xu \& Diamantina v IAG New Zealand, above n 569.

${ }^{576}$ Xu \& Diamantina $v$ IAG New Zealand, above n 569.

577 Doig v Tower Insurance [2019] NZCA 107,20 ANZ Insurance Cases 62-222.

${ }^{578}$ Doig v Tower Insurance, above n 577.

${ }^{579}$ Tower's payment was in addition to the EQC payment of $\$ 191,659$.

${ }^{580}$ The replacement cost was estimated between $\$ 923,000$ and $\$ 1.49$ million according to paragraph [42] of the judgment.
} 
was lucky to find the vendor (the interviewee's mother) and have her agree to signing the deed of assignment retrospectively. ${ }^{581}$ This shows that the purchaser's lawyer misunderstood the assignment issue.

EQC's stance might have added to the confusion. EQC provided the same entitlement to a purchaser under assignment as to the original owner. ${ }^{582}$ This is because EQC's obligations under the EQC Act are set on a reinstatement basis. EQC pays on a reinstatement basis regardless of who makes the claim.

In cross-lease claims, selling subject to assignment delayed claims resolution for the other owners. There was always a time delay with the new owner taking over the title and getting up to speed with the repair efforts.

Not only that, but people claiming under assignment did not have recourse to an insurance policy and unlimited resources to fund a rebuild. They had to come up with the shortfall themselves and this was difficult. This was especially the case when they purchased the property in reliance of a policy entitlement that did not eventuate.

For Body Corporates and company share properties, the situation was different. Because the party insured is the Body Corporate or the company, a change in the underlying unit ownership does not affect the application of the insurance policy. ${ }^{583}$

Another issue that came up following the earthquakes (later in time compared with assignments) were properties that were sold on an as is where is basis, colloquially known as on-solds. These were properties that might have been sold damaged or with uncertain repairs, but without an assignment of insurance rights. Where people purchased on an as is where is basis, they often did this with some budget in mind. If that budget was exceeded, they would be reluctant or unable to spend more. One participant at the Focus Group discussion explained the dilemma: ${ }^{584}$

\footnotetext{
${ }^{581}$ Interview with Homeowner 2.

${ }^{582}$ EQC “Buying or selling a home, or just transferring an EQC claim?" < www.eqc.govt.nz>.

${ }^{583}$ Interview with Young Hunter; Interview with IAG New Zealand.

${ }^{584}$ Focus Group discussion.
} 
You had people who have just taken the [insurance] money and sold out. And then someone else had bought it intending to do a patch up, to rent it out. They were not interested in doing a full scope [repair]. In my experience those claims tended to be paid out [as cash settlements, rather than repaired]. The elderly vulnerable couple of the unit in the end ... goodness knows what they did in the end.

\section{RAS experienced similar attitudes: ${ }^{585}$}

[T]hey bought it thinking it's going to cost $\$ 50,000$ but it's $\$ 110,000$ that they need to contribute. And they won't do it. And that's not a claim settlement issue.

You have no claim, you know what you bought, you're looking for a bargain. But for the compliance of that building, for the value of all the other titleholders, for the insurance that you need to have at the end of it ... "I don't need insurance, I selfinsure" they'll say.

One desperate owner applied to the Court for an urgent interim injunction to stop their neighbour selling their flat. ${ }^{586}$ In that case, two units shared a party wall that required joint repairs. Despite the initial assurance from one of the owners that they would apply the insurance cash payment toward the repairs, the owner instead put the unit on the market on an as is where is basis. The Court acknowledged that on the face of it, the intended sale amounted to a breach of the lease terms, and that the intention of the neighbour to sell the property "as is" and "disappear" required an urgent response. ${ }^{587}$ As a result, the Court granted an interim injunction to stop the neighbour selling the flat until the parties' obligations were clarified.

In these cases, there was often a lack of money to carry out full repairs by the purchasers. While it was not strictly speaking underinsurance (as they would not have

\footnotetext{
${ }^{585}$ Interview with specialised contractor with RAS.

${ }^{586}$ McEwan v Curtis [2015] NZHC 2258.

${ }^{587}$ McEwan v Curtis, above n 586 at [12].
} 
insurance when buying as is where is), it had a similar effect in that one owner did not have sufficient funds to repair their unit.

\section{Underinsurance and non-insurance}

The sixth and final aspect of the human element is related to underinsurance and noninsurance. By international standards, the Canterbury earthquakes were a well-insured event. ${ }^{588}$ However, the research revealed that with multi-unit building claims, there was some underinsurance. ${ }^{589}$

Insurance companies that responded to the online survey referred to underinsurance being somewhere between 10-50 per cent of cases. When asked to write in free text what they thought were the top three issues affecting the resolution of multi-unit building claims, the insurance companies mentioned underinsurance four times, with one providing more detail in saying: 590

Lack of full insurance cover (despite the Cross Lease obligation to be fully insured) sometimes caused delays while creative solutions were developed.

There were instances of underinsurance: ${ }^{591}$

Unfortunately, a lot of elderly people of course on cross-lease, could only afford small premiums, could not understand why they should increase the Sum Insured. Sometimes the Sum Insured was under the $[E Q C]$ cap or just above it.

Some people did not insure their property at all: ${ }^{592}$

\footnotetext{
588 Treasury New Zealand's Future Natural Disaster Scheme, above n 277 at 1 and 8.

589 Online survey insurance companies; Interview with Residential Risks Analysis; Interview with RAS; Interview with Young Hunter.

${ }^{590}$ Online survey insurance companies.

${ }^{591}$ Interview with Residential Risk Analysis.

592 Interview with Residential Risk Analysis.
} 
[We] also found that people who had no mortgage had no insurance so there were a lot of flats that just didn't have insurance policies.

mainly older people [had] no insurance because as far as they're concerned they have no debt so they don't need insurance, completely unaware that if their home is destroyed, what are they going to do? They just haven't thought it through and that continued to the Kaikōura earthquake.

Non-insurance was not prevalent, but it did cause problems when it arose: $:^{593}$

[Non-insurance] would be an issue at times and could push claims toward cash settlement.

[If] you had an uninsured party, the question was whether they would engage in the [joint repair] process because you couldn't force them to.

\section{Causes of underinsurance}

There were multiple causes for underinsurance. The first one was that people intentionally chose to underinsure either because they thought they had no risk or because they could not afford higher premiums.

The second cause was not a real situation of underinsurance but the owners' actions had led them to be short of funds for the repair. These were situations where insurers made cash payments. When that happened, sometimes homeowners spent some of the money on other things, like a car or a holiday and then became short for the repairs. As one interviewee put it: 594

They had payouts but there was a brand new boat sitting in the front garden, or a new car. The money had already been spent on something else and with no hope of retrieving that back.

\footnotetext{
${ }^{593}$ Interview with Nine Dots.

${ }^{594}$ Interview with Residential Risk Analysis.
} 
people living on a pension suddenly getting a waterfall of money like $\$ 150,000$, $\$ 200,000$, and you really don't see anything wrong with your flat, and you have no idea you have a liability to others in other flats, you're spending it on things you would've liked to have at some point in the past that you couldn't afford.

You then have at the other end of the extreme you have landlords who are tenanting these properties. So, you have transient population and landlords [who] are absent so they have no emotional attachment to that property, it's purely a business transaction. A lot of time with landlords all they could see was cash settlement and it was dollars in their eyes that they could get a cash settlement and use that money to invest elsewhere. So, money that was paid out by insurance didn't go on site.

A third cause of underinsurance was assignment of insurance claims. Sometimes owners sold the properties in their damaged state and assigned their insurance claims to the purchasers. It is not difficult to imagine how this happened. There was misunderstanding in the legal profession, the real estate industry, and between homeowners about what could be claimed under an assigned claim. Under an assigned claim, owners can only claim Indemnity Value. As such, the owners claiming under assignment did not benefit from Full Replacement cover and found themselves falling short if the building had to be rebuilt or required significant repairs.

Sometimes people were thrown into a situation of assignment through no fault of their own. This was when people purchased their properties thinking they had been repaired, only to find out later that the damage was more extensive than initially believed, that the cost of damage was in fact over the EQC cap, and that they had to make a claim on the insurance company under an assigned claim. I interviewed a homeowner of a cross-lease flat where this situation arose. ${ }^{595}$ There were ten flats in total. EQC's initial assessment was that the flats suffered cosmetic damage only. EQC paid each owner around \$2,000 and the owners organised the repairs. Five years later, one owner discovered that the sewerage was backing up. Upon investigation, an engineer found that the building had split in two and one side

\footnotetext{
595 Interview with Homeowner 2.
} 
was subsiding while the other end of the building was lifting. EQC engaged two other engineers who found the same structural damage. It was then decided that the building was a total loss. By that stage, five years later, a number of owners had sold their flats. These flats were sold on the basis that they had no defects and all the work scoped by EQC was completed. Luckily, it seems all purchasers arranged an assignment of the previous owners' insurance claims ${ }^{596}$ and therefore were able to draw on some benefits under the previous owners' policies. However, as with any other assigned claim, they could not benefit from Full Replacement cover and could only claim on an Indemnity Value basis. If EQC had correctly identified the damage from the beginning, the original owners would have had sufficient money to carry out reinstatement before selling. ${ }^{597}$ The difference between the cost of rebuild and the Indemnity Value payment was around 50 per cent in that case. So, the owners who only had an Indemnity Value policy or who claimed under assignment would have had to contribute half the cost of the rebuild from their own funds.

The fourth cause of underinsurance was again linked to cash payments but this time related to payments made to the banks as mortgagees. Technically speaking, this is not true underinsurance, as there might have been full cover available under the policy, but because the money was used somewhere else, it had the same effect as underinsurance.

Banks are noted on the policies as interested parties that have a claim to the money. When EQC or the insurer cash settled claims, the payment might have discharged the mortgage but when the time for reinstatement came, a few years later, sometimes the banks refused to release funds on the basis that the owners no longer met the lending criteria due to age. ${ }^{598}$ This would lead to a tension between the bank and the owner in relation to the application of the insurance money toward reinstatement. A homeowner recounted their experience:599

I called my bank and said how does this work with my mortgage? And they said no, the settlement will have to go to them and discharge the mortgage. And then if I needed

\footnotetext{
${ }^{596}$ Except one owner who was advised by her lawyer not to sign the deed of assignment.

${ }^{597}$ Except one owner which, apparently had an Indemnity Value policy only. He was the only one out of ten that did not have a Full Replacement policy originally.

${ }^{598}$ Interview with RAS.

${ }^{599}$ Interview with Homeowner 2.
} 
to borrow money for the rebuild in theory it would have to be a construction mortgage.

And there were a whole heap of rules around that.

If the banks called in the mortgage, this had the potential to create situations where owners were short of funds for the repair.

For their side, banks reported that they were not always paid first. One complained about the insurer paying owners directly without reference to the bank's interest: ${ }^{600}$

The major issue was the insurer cash settling directly with the customers despite having the bank noted as an interested party. That left us with a seriously devalued security.

That suggested that owners did not use the cash settlement to repair the building, which led to a devaluing of the property used as security.

A fifth cause of underinsurance was inadequate valuations. ${ }^{601}$ This was relevant to Body Corporate claims insured under MD policies that require valuations. Sometimes there was laxity in getting the valuations, which meant that they were not up to date. ${ }^{602}$

Finally, a sixth cause of underinsurance was the escalation of costs. There was a large increase in the cost of building materials post-earthquake. ${ }^{603}$ However, where owners had Full Replacement policies, these provided for the escalation of costs. It was only where owners had an Indemnity Value policy or a policy subject to a Sum Insured that the risk of cost escalation moved to the owners.

\footnotetext{
${ }^{600}$ Toomey Finn research paper, above n 26 at 78.

${ }^{601}$ Interview with IAG New Zealand; Interview with Young Hunter; Interview with Storm McVay; Interview with Residential Risk Analysis. Commercial properties, also insured on a Sum Insured basis, appear to have had the same problem with underinsurance. This appears to have been the case in previous events, such as the Gisborne earthquake on 20 December 2007. See also Felicity Powell "Urban earthquake events and businesses: learning from the 2007 Gisborne earthquake in New Zealand” (2010) 25 AJEM 54 which found that despite 77 per cent of businesses having insurance, most of them were not intending to make a claim.

602 Interview with Crombie Lockwood.

${ }^{603}$ Interview with Crombie Lockwood; Toomey Finn research paper, above n 26 at 214.
} 


\section{Problems caused by underinsurance}

Underinsurance created problems not only for the flat owner who was underinsured, but for the remaining owners. That is the domino effect I mentioned earlier, where one owner's decision affects the others. One interviewee described the experience of a claim that involved six flats in a two-storey building: ${ }^{604}$

Upstairs was owned by three young men, full insurance, their first houses - that's the upstairs flats. Downstairs was one flat owned by a little old lady and she only had a Sum Insured policy for $\$ 100,000$. So once EQC had paid out, she had nothing left. The other two flats were owned by a wealthy old lady who rented them out and she only had them insured for indemnity, so there was underinsurance downstairs. So, we had the young men upstairs fully insured and we had the little old ladies downstairs who are underinsured. But because of that underinsurance there were six people out of houses because they never went ahead with the reinstatement. That was a particularly nasty site because [of] the old lady downstairs who had the investment flats. She was very shrewd and she hung out and hung out to the point where she was able to buy the land shares off the young men for below market rates because they needed the money, [so] that they could get to try find something else because even though she was reminded of her requirements under the Memorandum of Lease, she had the resources to fight it and delay it and stall it forever, whereas these young men who were just starting out and had mortgages, they couldn't afford that waiting game. So that to me was just an early example of what people do to each other.

Lack of money to complete the repairs for the flats that were underinsured or non-insured delayed the repairs to the flats that were fully insured. This is because the uninsured or underinsured owner had to come up with the shortfall, and sometimes this was complicated. One homeowner illustrated this point, recounting what happened to his cross-lease flat: ${ }^{605}$

Initially there was a lot of debate back and forth over do we want to manage the repairs ourselves or do we sell to a developer ... I was keen on a managed repair because that would save all the hassle of working out what to do afterwards. If we were to organise

\footnotetext{
${ }^{604}$ Interview with Residential Risk Analysis.

${ }^{605}$ Interview with Homeowner 2.
} 
the repair, it would have been a logistical nightmare. I voted for - I was hoping for a managed repair. The reason there was no managed repair was because of the change of owners ... they were insured at Market Value. ${ }^{606}$ And one of the properties was actually insured for Market Value as well. It hadn't changed hands, but it was insured at Market Value. So that was the roadblock to having an insurer-managed repair.

Often owners had different levels of cover. The lack of uniformity meant that different owners were at different stages with their insurance cover. Sometimes, even when the neighbours had the same type of insurance (for example, Full Replacement), they might have had different outcomes with their insurer. One interviewee had a damaged shared driveway for a cross-lease property. Their insurer offered to pay half of what the neighbour received from their insurer, which meant that they did not have sufficient funds to pay for a joint repair with the neighbour. ${ }^{607}$ It took a long negotiation for the insurer to match what the other insurer offered.

When owners have different levels of cover, it is more difficult to resolve the insurance claim for the multi-unit building. EQC described some of the situations they encountered:608

[Where we had challenges was where] the repair costs exceeded the EQC cap and [the owners] are in a situation where they are an overcap property, but they don't have any insurance. That's where the on-sold overcap comes in, which we can talk about. The other situation is where we presented an offer and we found an owner where they have an Indemnity Policy or a Market Value/Present Day policy where they have reduced insurance. It becomes difficult then because these customers potentially then have to put in their own money to top up to what the actual repair costs are going to be.

[It was] rare, but it was the case on a couple of occasions, we were not able to offer a joint repair because that particular customer never had insurance, remained damaged,

\footnotetext{
${ }^{606}$ A number of units were sold before the repairs were carried out and the purchasers claimed under assignment and therefore had reduced benefits, see "Assignment and On-Selling" above.

${ }^{607}$ Interview with Homeowner 1.

${ }^{608}$ Interview with EQC.
} 
nothing has been done and there is no appetite for them to heavily invest their own money to get the repairs with the other owners.

\section{Underinsurance for Body Corporates}

For Body Corporates, underinsurance was the most significant issue. ${ }^{609}$ IAG's experience was that almost every single Body Corporate in Canterbury was underinsured. ${ }^{610}$ That was evident when they suffered a total loss. Young Hunter Lawyers dealt with many Body Corporate claims in Christchurch. Their opinion was that probably all of the Body Corporates were underinsured. ${ }^{611}$ This opinion was echoed by other lawyers working in Christchurch: ${ }^{612}$

One of the biggest issues facing Body Corporates is the lack of insurance cover. It has become quite apparent that unit title developments are heavily under insured and Body Corporates are scrambling to figure out how to apportion the insurance cover that is available among units and how to deal with contribution of any shortfall by the unit owners. If the Body Corporate resolves to rebuild (even without the agreement of all owners), it has powers under the Act to force owners to pay any shortfall.

Different from owners of residential properties who had the option of taking a Full Replacement policy, the Body Corporates operated within a Sum Insured environment. They had to specify the sum they wanted to insure the building for. This generally had to be supported by a valuation. ${ }^{613}$ Despite a professional valuation, the experience from the Canterbury earthquakes was that the Sum Insured was inadequate. ${ }^{614}$ One broker thought

\footnotetext{
${ }^{609}$ Interview with IAG New Zealand; Interview with Crombie Lockwood; Interview with Young Hunter; Interview with Grant Shand Barristers and Solicitors.

${ }^{610}$ Interview with IAG New Zealand.

${ }^{611}$ Interview with Young Hunter.

${ }^{612}$ Land and Ballinger, above $\mathrm{n} 17$.

${ }^{613}$ This is generally required by material damage policies. For example, in Body Corporate $398983 v$ Zurich Australian Insurance [2013] NZHC 1109, (2013) 17 ANZ Insurance Cases 61-972, the Body Corporate had obtained a valuation in mid-2010 and engaged a broker to obtain two reinstatement quotes. The Sum Insured was based on this information and set at $\$ 12,950,000$. When they suffered a total loss a few months later, the losses were estimated at $\$ 25,000,000$ so they were underinsured by about half.

${ }^{614}$ Interview with IAG New Zealand; Interview with Young Hunter; Interview with Storm McVay; Interview with Crombie Lockwood.
} 
that the Body Corporates were slack in getting the valuations done regularly, noting that some valuations were five years old. ${ }^{615}$

Sometimes the issue was not just one of an inadequate valuation, but of escalation of costs. There was a large increase in the cost of building materials post-earthquake and at the height of the earthquake repairs, builders could just "name their price". 616

Lack of money made claims difficult to manage as the Body Corporates had to find ways of obtaining from the insurers more than the Sum Insured. This led to litigation. Two types of claims were usually advanced: one based on the argument that, since the Body Corporate suffered losses in multiple events, the Body Corporate was entitled to more than one Sum Insured (one per event). ${ }^{617}$ Another argument was that the Sum Insured was in addition to the EQC cover. ${ }^{618}$ These points were tested in Court in relation to commercial properties that were subject to MD policies similar to those for Body Corporates, including having a Sum Insured. Comparable arguments were raised by Body Corporates in their dealings with insurers. ${ }^{619}$

The court decisions helped clarify the legal position and entitlement under the insurance policies. This assisted in resolving similar claims.

Where Body Corporates were underinsured, it was difficult to raise the money to reinstate the building. The historic Cranmer Courts apartment building in Christchurch was one of those. The building suffered significant damage. CERA issued a section 38 notice under the Canterbury Earthquake Recovery Act 2011, asking it to be made safe or be demolished. Its demolition caused an outcry from heritage supporters. ${ }^{620}$ The owners did not have

\footnotetext{
${ }^{615}$ Interview with Crombie Lockwood.

${ }^{616}$ Interview with Crombie Lockwood; Toomey Finn research paper, above n 26 at 214.

${ }^{617}$ Interview with Young Hunter. One of the major cases was Ridgecrest $v$ IAG New Zealand, above $\mathrm{n} 315$; see also Body Corporate 78462 v IAG New Zealand [2016] NZHC 320, 2016 WL 947184. Another important decision touching on underinsurance was QBE Insurance $v$ Wild South Holdings, above n 330.

${ }^{618}$ Firm PI 1 Ltd $v$ Zurich Australian Insurance, above $\mathrm{n} 410$.

${ }^{619}$ Interview with Young Hunter.

${ }^{620}$ Toby Manhire "Cranmer Courts: Christchurch heritage reduced to mulch" Noted (online ed, 4 October 2012); Joelle Dally “Eleventh-hour offer may save Cranmer Courts" Stuff (online ed, 25 August 2012); Cullen Smith "Cranmer Court demolition all 'bad news"” The New Zealand Herald (online ed, 5 October 2012).
} 
sufficient insurance to rebuild. They had to walk away from the building. In one media report, journalist Toby Manhire reported that: ${ }^{621}$

The owners - 31 apartment owners, tied together as a Body Corporate - have received their insurance payout on the building but they need to be able to sell the land to move on. Many of them are elderly, are displaced from their homes, and don't have deep enough pockets to rescue the building.

The Body Corporates that were underinsured and unable to raise the money to rebuild were not technically entitled to the rebuild cost in the form of a cash payment. As discussed in Chapter III, an insurance policy provides a reinstatement entitlement only if the policyholder carries out the reinstatement. An insured party who is not proposing to repair or rebuild for whatever reason (including lack of funds) is only entitled to the indemnity value of the building, which is often much less than the reinstatement cost. It is unclear how this was dealt with by the insurers. One insurer appears to have made cash offers on a reinstatement basis: ${ }^{622}$

In 2013 we agreed with our reinsurers that we could exceed the terms of the policy and offer to cash settle customers on the basis of the estimated cost to repair/replace their home. We felt that offering this to our customers would provide them greater certainty and a quicker path to move on with their lives.

It is possible that other insurers did the same, or that the Sum Insureds were so low, they were closer to the indemnity value anyway.

Underinsurance seemed to be prevalent where there was a Sum Insured policy. It illustrates how difficult it is to get the Sum Insured right. The Body Corporates had professional valuers to assist them and that still fell short when there was a total loss. This is a matter of concern with residential dwellings now operating within a Sum Insured environment. Underinsurance is a major obstructer in getting a multi-unit building reinstated.

\footnotetext{
${ }^{621}$ Manhire, above n 620.

${ }^{622}$ IAG New Zealand "Submission on Insurance Contract Law Review", above n 440 at 24.
} 


\section{Technical Issues}

Aside from the human element, multi-unit building claims presented a number of technical issues. These can be broken down into four categories.

1. Building complexities.

2. Specialist knowledge.

3. Pre-existing defects.

4. Defective titles.

The technical issues underscore the repair dependencies specific to multi-unit buildings.

\section{Building complexities}

In the period immediately after the Canterbury earthquakes, EQC and insurers treated cross-lease properties in the same way as any other properties. EQC set up what was known as the Canterbury Home Repair Programme, ${ }^{623}$ which had an automated system where claims under $\$ 15,000$ would be cash settled and those between $\$ 15,000$ to $\$ 90,000$ would be sent into a "repair bucket" to EQC's appointed project manager, Fletcher Earthquake Recovery (Fletcher EQR). Fletcher EQR would action the repairs to the flat or unit without considering the damage to the other flats or to the building as a whole. Insurers proceeded on the same basis, dealing with the flats they were insuring. ${ }^{624}$

\footnotetext{
${ }^{623}$ EQC "EQC and Fletcher EQR announce repair timeframes" (20 December 2011) <www.eqc.co.nz>. ${ }^{624}$ Interview with RAS.
} 
Eventually, insurers realised multi-unit buildings were a "shared risk". ${ }^{625}$ This realisation came in around $2012 .{ }^{626}$

One of the most important lessons learnt from the Canterbury earthquakes is that, where the common elements of a building are affected, multi-unit buildings cannot be repaired in isolation. ${ }^{627}$ The thesis uses the term repair dependency to describe a situation where there is a possibility a unit might not be able to be repaired separate from the neighbouring unit or units.

Insurers tried to work with each other in order to progress the repairs, but they were not always able to agree on the scope of work. Some had engineers advising them the units could be repaired; others had advice to the contrary, that the units had to be demolished and rebuilt. An article from a Christchurch-based law firm painted a grim picture: 628

Cross lease properties are facing lengthy delays to have their repair work signed off by the EQC and their private insurer, especially where the flats are joined by party walls and each owner insures their flat with different private insurance companies. The delays are commonly because of the interaction required between insurance companies and the differing scope of works and repair strategies for repairing damage, and the timeframes for completion. For example, one insurance company may commit to replacing one flat, but the insurer of the adjoining flat may deem that flat a repair. This may lead the owner to objecting and negotiating with their insurer, which then effectively puts the first flat's rebuild on hold until the second flat's insurance issues are resolved.

Over time, insurers considered the possibility of a joint approach. Six insurers - IAG, Vero Insurance, Southern Response, Tower, AA Insurance, and Lumley - together with EQC established a scheme called the Shared Property Pilot where six difficult cross-lease sites

\footnotetext{
${ }^{625}$ Interview with specialised contractor with RAS.

${ }^{626}$ Interview with Vero Insurance; interview with Residential Risk Analysis; Focus Group discussion; interview with Nine Dots.

${ }^{627}$ Interview with RAS.

${ }^{628}$ Richard Lang and Janine Ballinger, Duncan Cotterill (a law firm) "Web of insurance issues in cross lease properties" Mondaq (online ed, 10 May 2013).
} 
were chosen as a trial. Nine Dots Ltd, a company with management and loss adjusting experience, managed the Pilot. The Pilot then rolled into a full-scale enterprise called the Shared Property Project. This was a sui-generis project designated for resolving complex insurance claims for cross-lease properties which I mentioned in the Introduction.

I interviewed personnel from Nine Dots who were responsible for setting up the Shared Property Project. One of the impediments in getting the Shared Property Project initiative off the ground was the insurers' concern with sharing customer information with others due to privacy concerns. It took almost 18 months and "hundreds and hundreds of emails" $" 629$ for agreement to be reached, safeguards to be put in place, and the information to be provided to Nine Dots.

EQC faced the same problem: ${ }^{630}$

Another issue was sharing information. We had to cut through a lot of red tape and ... share information in our collaborative database.

But releasing information on cross-lease situations, where people didn't sign a release to give information to their neighbour, theoretically, we had to have consent.

We talked to [Nine Dots and they] went to the Privacy Commissioner.

Those privacy concerns were shared by others: ${ }^{631}$

No matter what we tried, we even flew lawyers down from Auckland or Wellington or what not to talk to people. We put so much in the way of funding into this but we were trapped by the Privacy Act. We tried to get around that by getting everybody to site to sign waivers because the only way for reinstatement to go ahead is if everyone's got a shared vision. That was hard because people didn't want their neighbours to know these things, particularly if there was underinsurance or no insurance on site. The issues with the Privacy Act as well meant we couldn't bring in third parties.

\footnotetext{
${ }^{629}$ Interview with Nine Dots

${ }^{630}$ Focus Group discussion.

${ }^{631}$ Interview with Residential Risk Analysis.
} 
For Nine Dots to set up a process, they needed to know the location of the cross-lease properties, which insurer insured which flat, and that a claim was lodged. There was no centralised database. A centralised database was set up for the purpose of the Shared Property Project to which only Nine Dots had access. ${ }^{632}$ To qualify into the Shared Property Project, a property had to be on a cross-lease title and have at least three flats insured by at least two different insurers. In the end, the Shared Property Project had 250 sites involving 1,200 individual claims. ${ }^{633}$

Once the properties were identified, it was decided that the best way forward was for there to be a single decision-maker and point of contact. That led to the appointment of what was known as the lead insurer. Basically, one insurer would take the responsibility for overseeing the repairs to the property as a whole, including the flats it did not insure. That was unprecedented. ${ }^{634}$ It meant that an insurer with no contractual relationship with some of the owners in the development would lead the reinstatement programme and make decisions on how the flats were reinstated.

The lead insurer would appoint a loss adjuster ${ }^{635}$ and a project manager (PMO) who would then organise the necessary investigation regarding the extent of repairs and scope of works and get the building contract signed. The loss adjuster would liaise with the homeowners to get their agreement for the repairs. The process was "excruciatingly slow ... because the PMOs ... had a full book of business already. The bottlenecks were geotech engineering and structural advice". ${ }^{636}$ Nine Dots gave me some numbers showing the time lapse between a property coming into the Shared Property Project and the starting date of construction. It would generally take between 18 months to two years for the construction to start. It is possible that owner delays contributed to the finalisation of the design process and signing of the construction contract.

\footnotetext{
${ }^{632}$ Nine Dots told me that this was destroyed in 2017 at the end of the project.

${ }^{633}$ Interview with Nine Dots.

${ }^{634}$ Interview with Vero Insurance.

${ }^{635}$ From a pool of adjusters pre-approved for the Shared Property Project.

${ }^{636}$ Interview with Nine Dots.
} 
If there were any earlier repairs, these were ignored and in many cases those costs were wasted.

The lead insurer would invoice the follow insurers for their share of the cost according to an agreed split. The lead insurer would generally be the insurer who had the most interest (insured flats) in the development. If the numbers were equal, the insurers would agree who would take the lead.

Because there were multiple insurers, there was generally more than one technical opinion on how to reinstate the property. The Shared Property Project offered a solution to this problem as it avoided disagreements between insurers in relation to the reinstatement proposal $^{637}$ as only one insurer would be involved as the lead. The others followed the lead's decision. This had the effect of reducing the number of decision-makers, and enabling a more efficient exercise of the decision dependency. Unknowingly, the insurers created a governance structure at the insurer level and removed the double decision dependency.

One issue that arose was how to handle a situation where to repair one flat you had to damage the neighbouring flat (known as collateral damage). Insurers decided to let the costs lie where they fall. ${ }^{638}$ Insurers agreed to absorb the cost of incidental damage caused to the units they insured, even when the damage was caused as a result of repairs carried out to the neighbouring units. This agreement was made to avoid further complications with the claims. It is similar in nature with what insurers currently do in the Knock for

\footnotetext{
${ }^{637}$ Online survey ICNZ.

${ }^{638}$ Interview with Nine Dots.
} 
Knock Agreement for motor vehicle claims ${ }^{639}$ or the Standstill Agreement for house and contents claims. ${ }^{640}$

The insurers engaged Young Hunter Lawyers to advise them on the legal aspects of the Pilot and then the Shared Property Project, including the basis of cost-sharing. Most of the queries were related to some smaller issues but that still required clarification between insurers, as that determined the calculation of their contribution to the overall cost. Young Hunter listed some issues that arose: ${ }^{641}$

You would think [the flats] would all be the same size but sometimes there's actually variation between them. You know, just subtly, but that meant that when it came to a cost-sharing, the issues then arose in terms of well you've only got $33 \%$ of the foundation or you have $47 \%$ of the walls or whatever it might be.

... whilst a number of these properties had ... a shared driveway over the concrete driveway they didn't always have an equal obligation to pay for part of it. So, my final one had one at the front and a property at the back had a greater share of the driveway so there's a greater obligation on the insurer to move that concrete. I think the main issues that arose were driveways, foundation, the walls, defective titles and how to deal with those.

Once the Shared Property Project came into play, no insurer could cash settle without discussion with the others. If one decided to settle, then they all cash settled. ${ }^{642}$ This was due to the perceived difficulties in reinstating the building where there was insufficient money.

\footnotetext{
${ }^{639}$ The Knock for Knock (also known as $\mathrm{K} 4 \mathrm{~K}$ ) is an agreement between insurers companies that they will each pay their customers' loss following a motor vehicle accident irrespective of whose fault it is and without seeking recovery from the party at fault. Avoiding recovery actions or litigation is seen as an efficient way of handling claims and over time, the costs are spread fairly across insurers. <https://en.wikipedia.org/wiki/Knock-for-knock_agreement>.

${ }^{640}$ The Standstill Agreement is an agreement between a few major insurance companies and operates similar to the Knock for Knock Agreement described above but it applies to house and contents claims of a certain monetary value.

${ }^{641}$ Interview with Young Hunter.

${ }^{642}$ Interview with Vero Insurance; Interview with Nine Dots; Interview with Residential Risk Analysis.
} 
The Shared Property Project protocol required the owners to pay any previous settlement money (either from EQC or from their insurer) up front to ensure the construction could be finalised. If they were unable or unwilling, the repair programme would not proceed, and the owners would receive a cash settlement.

The project took some time to get off the ground. In 2015, it was reported that only seven multi-unit buildings were under construction: ${ }^{643}$

Nearly two years on from the time the pilot was launched, only about seven of the 154 complex MUBs in ICNZ's Shared Property Programme are under construction.

ICNZ confirms 54 have fully completed plans or are going through the consenting process.

Less than eight sites have an uninsured party involved.

Another 34 sites are being evaluated, to see whether they'll become part of the programme.

A total of 932 individual units are involved in the 188 sites either in the full programme or being considered for it.

The Shared Property Project required the insurance industry to work collaboratively with each other. The feedback received from those interviewed and surveyed was that it was a positive and effective initiative. ${ }^{644}$

RAS saw the Shared Property Project as "God sent" 645 because it reduced the communication across different insurers and avoided confusion in relation to the way to move forward.

In my view, the Shared Property Project was effective because it eliminated the double decision dependency. The insurers created a governance structure of their own to enable a more efficient decision-making process between themselves.

\footnotetext{
${ }^{643}$ Jenee Tibshraeny "Reconstruction underway on just 7 of 154 'complex' multi-unit Canterbury buildings 4 years after biggest earthquake” Interest (online ed, 24 February 2015).

${ }^{644}$ Online survey ICNZ; Online survey of lawyers (Emma Gabor, Wellington, 22 January 2018); Online survey of EQC (Emma Gabor, Wellington, 22 January 2018); Online survey of insurance companies.

${ }^{645}$ Interview with RAS.
} 


\section{Specialist knowledge}

The size of most multi-unit buildings means they are similar to commercial buildings, which requires involvement of a large construction company and proper project management.

Some interviewees believed owners were not capable of organising themselves or managing a large repair programme: ${ }^{646}$

If we couldn't get everybody over the line (and we're a big bully insurer) these individuals are never going to be able to coordinate themselves. All the required resources and specialists and large contracting companies like Hawkins, these are actually the only type of people that could actually do these reinstatements because they are industrial-sized buildings.

The sentiment was echoed by others: ${ }^{647}$

[M] ost [of the owners] are vulnerable.

..

there are a lot of old people [and it is difficult for them] to engage a project manager, a builder to manage the project, and do all that sort of stuff.

Sometimes, the project required hard decisions to be made. For example, some homeowners wanted to take advantage of the rebuild to improve the layout of the flat or add additional rooms or features. This held up the process for everyone else. One insurer was cited saying: ${ }^{648}$

\footnotetext{
${ }^{646}$ Interview with Residential Risk Analysis.

${ }^{647}$ Interview with RAS.

${ }^{648}$ Interview with insurer cited in Toomey Finn research paper, above n 26 at 20.
} 
Even if we allowed it [betterment], getting the money from the customers to allow to pay [for example] the bay window was causing problems ... and it was causing more trouble than it was worth. You know one person's bay window was holding up the whole site so in the end the insurers just said 'enough of this' and we forced everybody to build exactly what they had - in some we would allow them to move things internally but not the actual structure, for example, changing the position of the toilet $\ldots$ as for extending the footprint, we refused. They had to stick solid to that ... no movement there.

In relation to Body Corporate claims, one of the difficulties was determining the extent of damage and whether the building was a total loss. This is because Body Corporates can have several structures or adjacent buildings such as car-parking buildings. As one interviewee put it: ${ }^{649}$

Unit titles were different ... you've actually got a single unified body, a corporate entity basically that manages the claim. But there was usually much more technical complexity in terms of the engineering and earthquake damage typically because the building is complex.

One insurer agreed: ${ }^{650}$

With the Body Corporate, for a start, it was much more difficult to assess whether the property was in its entirety a total loss. Sometimes they were multi-unit buildings, sometimes there were towers, sometimes they had carparks buildings attached to it ... so they required a special technical expertise.

Assessment of loss and repairs took a long time. Owners reported delays in having their claims processed, and disagreements on the technical assessment of damage and on the standard of repair. ${ }^{651}$

\footnotetext{
${ }^{649}$ Interview with Lane Neave.

${ }^{650}$ Interview with IAG New Zealand.

${ }^{651}$ Toomey Finn research paper, above n 26 at 211; Interview with Crombie Lockwood.
} 
One group of apartment owners decided to pay for their own engineering assessment to speed things up: ${ }^{652}$

We actually paid for DEE [Detailed Engineering Evaluation] ${ }^{653}$ We went through all that process because it seemed that multiple owner buildings were being left to be the last ones, that was the talk on the street. [EQC] were giving these statistics of such a percentage of claims being resolved, and they were all houses, mostly homes but they were just looking at one thing, but [our apartment building] was actually 29 homes. So, [multi-unit buildings] were definitely the poor cousin.

One company-share property with 54 units in Wellington that was damaged in the Kaikoura earthquake reported that it had to wait from November 2016 (when the earthquake happened) to May 2017 to have a loss adjuster come on site for assessment, which was the first step in the assessment of damage. ${ }^{654}$ There were disagreements about the scope of repair, cover for the asbestos removal cost, and extent of damage. ${ }^{655}$

Some people did not want to wait for the reinstatement or to deal with the developing issues: 656

A lot of the owners were old and retired and they didn't have the will to reinstate or wait around until the Body Corporate was going to rebuild. And of course, with the land situation as it was, some could not rebuild to the same footprint or to the size that was initially. Or in the suburbs, the land was not suitable for building that type of structure on it. And location is very important in real estate, so they had to make a decision where they were going to rebuild.

Where the Body Corporate had a mixed-use component (that is, part of its premises was used for commercial activities), there were further complications in calculating

\footnotetext{
${ }^{652}$ Interview with Homeowner 1.

${ }^{653}$ Detailed Engineering Evaluation, a type of structural engineering report.

${ }^{654}$ Interview with Roger Phillips.

655 Interview with Roger Phillips.

${ }^{656}$ Interview with IAG New Zealand.
} 
the EQC funding available, as EQC does not provide cover for commercial properties.

\section{Pre-existing defects}

Sometimes, pre-existing issues with the building affected resolution of insurance claims. The worst ones were leaky buildings. ${ }^{657}$ How to deal with asbestos removal was another issue. ${ }^{658}$ Initially, homeowners argued there should be cover where preexisting damage was exacerbated by the earthquakes, but, in a 2017 court case, ${ }^{659}$ the Court of Appeal applied the Wayne Tank principle ${ }^{660}$ in that where a loss had two effective and interdependent causes, one within the policy and one excluded by it, the loss would be excluded from cover. That case clarified the law and ended some of the existing disagreements. ${ }^{661}$

A broker described a case involving a leaky building. ${ }^{662}$ Insurance does not cover damage caused by water ingress so the parties had to agree how to manage a repair where the earthquake damage was covered by the policy, while the weathertightness work was not and had to be paid by the owners. The broker said that what helped in the situation was having a good loss adjuster, a builder, and a project manager the Body Corporate trusted. The builder had a separate billing code for the defective work and everyone was kept updated on the repairs as they progressed.

For some Body Corporates, a major issue was earthquake strengthening. This was brought into sharp focus by a rather extraordinary act of the Christchurch City

\footnotetext{
${ }^{657}$ Interview with Lane Neave.

${ }^{658}$ Interview with Roger Phillips.

${ }^{659}$ AMI Insurance v Legg, above $\mathrm{n} 292$. The case involved a fire which had been heaped with rubbish from a lifestyle block (covered by the policy) and with green waste from an associated business activity (excluded). The Court said the entire claim was excluded. Another case which applied the Wayne Tank principle was Sadat $v$ Tower Insurance, above n 293.

${ }^{660}$ Wayne Tank, above n 292.

${ }^{661}$ Interview with Lane Neave.

${ }^{662}$ Interview with Crombie Lockwood.
} 
Council, which, six days after the first of the Canterbury earthquakes, adopted a policy called Earthquake-Prone, Dangerous and Insanitary Buildings Policy 2010 (the Policy) requiring any earthquake-prone building to be strengthened to 67 per cent of the new building standard as the preferred level of seismic strengthening. ${ }^{663}$ This Policy applied to Body Corporates and other commercial properties but not to residential properties.

There was a debate about whether the insurers had to meet the cost of the strengthening work or whether this additional compliance cost fell on the Body Corporates. Many millions of dollars were at stake. Material damage insurance policies generally say that insurers would pay for the cost of reinstatement including any compliance cost necessary to achieve the reinstatement. However, insurance companies argued that the reinstatement work needed only to achieve the minimum legal standard of seismic strengthening, which was 34 per cent. Body Corporates would have preferred the insurance companies to pay for the earthquakestrengthening work to 67 per cent as required by the Council's Policy. The uncertainty in respect of obligations delayed the resolution of claims.

In 2012, on behalf of insurance companies, ICNZ took the matter to Court seeking judicial clarification. ${ }^{664}$ This was done by an application for judicial review of the Christchurch City Council's decision to adopt the Policy. ICNZ argued that the Policy was unlawful and illegal as the Council did not have the power to force owners to strengthen to 67 per cent. The University of Canterbury was named as a second respondent and the Body Corporate 423466 (Oxford Body Corporate) was the third respondent. ${ }^{665}$ The University of Canterbury had claims in the region of $\$ 500,000,000$. It was estimated that the difference between the insurance cover to

\footnotetext{
663 This was not a fixed requirement, and the Council was more interested in determining whether the risks and safety were properly addressed adequately.

${ }^{664}$ Insurance Council of New Zealand v Christchurch City Council, above n 320.

${ }^{665}$ It is possible that the second and third respondents were selected as representatives of their class, one for commercial properties, the other for residential Body Corporates.
} 
strengthen to 34 per cent as opposed to 67 per cent was about $\$ 140,000,000 .{ }^{666}$ The Oxford was a ten-apartment residential Body Corporate built in 2005 but which was severely damaged during the 4 September 2010 and 11 February 2011 earthquakes. They were added as parties on the understanding that they would not be liable for costs. ${ }^{667}$ The Court found that the Council did not have the power to require buildings to be strengthened above 34 per cent of the new building standard. Therefore, the solution was that the insurers did not have to pay for the cost of earthquakestrengthening above 34 per cent, but neither did the property owners. The University of Canterbury appealed the decision but lost both in the Court of Appeal ${ }^{668}$ and in the Supreme Court. ${ }^{669}$ Like other cases, the judicial decision enabled other claims to move on and be resolved.

\section{Defective titles}

The final point on the technical issues for multi-unit buildings is related to defective titles. This affected only cross-lease properties, but it was significant enough that it must be mentioned. Defective titles are not a problem specific to Christchurch, it is widespread. ${ }^{670}$ When changes are made to a cross-lease flat, say by adding a room, a conservatory, a deck, or a garage, the flats plan needs to be updated, otherwise the title becomes defective. That is because the ownership of the flat is delineated by the terms of the lease and the physical measurements noted on the title. Anything outside those specified boundaries is common property. To go outside those limits, a new flats plan needs to be drawn, deposited, and a new title registered.

\footnotetext{
${ }^{666}$ Insurance Council of New Zealand v Christchurch City Council, above n 320 at [14].

${ }^{667}$ Insurance Council of New Zealand v Christchurch City Council, above n 320 at [13].

${ }^{668}$ University of Canterbury $v$ Insurance Council of New Zealand [2013] NZCA 609, 18 ANZ Insurance Cases 62-001. Oxford Body Corporate was also an appellant in the Court of Appeal.

${ }^{669}$ University of Canterbury v Insurance Council of New Zealand [2014] NZSC 193, [2015] 1 NZLR 261.

${ }^{670}$ See comments made by Pidgeon, above $\mathrm{n} 1$.
} 
Sometimes, owners erect structures on restricted user areas. Each restricted user area is owned by all the cross-lease owners as tenants in common as to their respective title shares. ${ }^{671}$ In these cases, there is a possible argument that consent is not required, although "prudence dictates that a co-owner wishing to construct improvements in a restricted user area would be wise to obtain the consent of the other co-owners." ${ }^{672}$ In Smallfield v $B r o w n n^{673}$ the High Court held that an owner building a deck on a restricted user area and replacing a small window with a French door required consent from the other Lessor.

The Memorandum of Lease says that a Lessee cannot make alterations to the footprint of the flat without the consent of the Lessor. And even if consent is obtained, the owner needs to update the flats plan. The requirements can be quite onerous. A property lawyer listed the requirements as follows: ${ }^{674}$

If the title needs to be updated, the following will need to be undertaken (which can result in a cost of ten/s of thousands of dollars) and can take several months to complete:

1. The land will need to be resurveyed;

2. New legal titles will need to be issued;

3. All owners in the cross-lease development will need to sign the documents to enable the issue of new title;

4. Mortgagee consent of all owners in the cross-lease development will need to be obtained; and

5. Council consent will need to be obtained. We note that Councils treat this similarly to a "subdivision" and can impose requirements in order to give such consent, some of which can be costly. For example, upgrading the fire protection between any dwellings that are attached to another, or upgrading the services to the property, particularly if the services are shared.

\footnotetext{
${ }^{671}$ Rod Thomas, above n 142 at 1172.

${ }^{672}$ Rod Thomas, above n 142 at 1174.

${ }^{673}$ Smallfield v Brown (1992) 2 NZ ConvC 191,110. Also referred to in Rod Thomas, above n 142 at 1174.

${ }^{674}$ Lindsey Smith (Rainey Collins, a law firm) "What is a Defective Cross Lease Title? Still Causing Problems...!" (Online ed, 13 August 2018) <www.raineycollins.co.nz>.
} 
The Christchurch City Council website states: ${ }^{675}$

Where additions are made to the footprint of the existing building(s) shown on a crosslease title or new buildings are added, for example, a house extension or new garage, the crosslease title will generally need to be updated to show the changed building footprint. This is commonly known as the updating of the flats plan. Any updating of a flats plan is classified as a subdivision and requires subdivision consent. It is important to note that the building consent authorising the construction of the additions or new building does not automatically update the crosslease title, so a separate subdivision consent needs to be applied for.

It appears that defective cross-lease titles were a widespread issue. One interviewee estimated that "55-65 per cent of the cross-lease plans were in default, [and that] conservatories were the main issue."

EQC reported that, while they had no other issues with standalone cross-lease properties, there were issues with defective titles. ${ }^{677}$ EQC gave the example of a garage that had been built on common land but where the title had not been updated. EQC refused to get involved with the reinstatement work for what it perceived as an illegal structure. The claim was cash settled. Even for properties with no repair dependencies, the defective titles caused problems.

The insurers took the view that if the reinstatement work was going to result in a defective title, they would pay the cost to amend the flats plan. ${ }^{678}$ However, if the defective title was pre-existent, the cost to remediate the title fell on the homeowners. This put an additional cost on the homeowners. This in turn caused delays because of lack of funds.

\footnotetext{
${ }^{675}$ Christchurch City Council "Types of subdivisions" <www.ccc.govt.nz>.

${ }^{676}$ Interview with Residential Risk Analysis.

${ }^{677}$ Interview with EQC. EQC also mentioned matching cladding requests, but this seems to have been a small issue.

${ }^{678}$ Interview with Young Hunter; Focus Group discussion.
} 


\section{E The Kaikōura Earthquake}

Five years after the Canterbury earthquakes, on 14 November 2016, New Zealand experienced another significant earthquake event. It was a 7.8M earthquake and it hit near the small South Island town of Kaikoura. The effect of the earthquake was felt throughout the Kaikōura region and beyond, all the way to Wellington. As well as two deaths, significant damage was caused to roads, infrastructure, and residential houses in and around Kaikōura, and to mid-rise buildings in Wellington. ${ }^{679}$ GeoNet $^{680}$ reported that the earthquake and surface rupture involved more than 20 different faults, which was a world record, and it triggered the biggest local-source tsunami ${ }^{681}$ recorded in New Zealand since 1947.682

EQC received more than 38,000 residential claims totalling $\$ 1.84$ billion; more than half of it was for damage to Wellington buildings and businesses. ${ }^{683} \mathrm{EQC}$ declared the Kaikōura earthquake the second largest event in EQC's history after the Canterbury earthquakes. ${ }^{684}$

EQC trialled a new agency approach to resolving claims. In December 2016, EQC signed a Memorandum of Understanding with a number of insurance companies. ${ }^{685}$ This gave the participating insurers the right to assess and settle home and contents claims on EQC's behalf, including claims that were under the EQC cap. ${ }^{686} \mathrm{EQC}$ retained direct management

${ }^{679}$ Chris Barton "What Kaikōura Taught Us About Wellington” New Zealand Geographic (online ed, Auckland, February 2017).

${ }^{680}$ A collaboration between EQC and GNS Science.

${ }^{681} \mathrm{GeoNet}$ says the run up wave was around $6.9 \mathrm{~m}$ height, although the tsunami wave would have been $3-4 \mathrm{~m}$ above normal sea level when it reached the shore - "Kaikoura/Tsunami" <www.geonet.org.nz>. One house was damaged. See Liz McDonald "Little Pidgeon Bay cottage smashed by tsunami waves" Stuff (online ed, 14 November 2016).

${ }^{682}$ GeoNet "Kaikoura/Story" <www.geonet.org.nz>.

${ }^{683}$ Anan Zaki "Kaikōura quake insurance claims to be completed this year" Stuff (online ed, 9 January 2018).

${ }^{684}$ EQC "How we are settling Kaikōura claims" (22 August 2019) <www.eqc.govt.nz>.

${ }^{685}$ AA Insurance, AMI, FMG (Farmers Mutual Group), IAG's bank partners (ASB, BNZ, Westpac and The Cooperative Bank), Lantern, Lumley, Medical Assurance Society, NZI, QBE Insurance (Australia), State Insurance, Tower Insurance - Fintel, Tower Insurance, Vero Insurance (including AMP, ANZ, and Warehouse Money policies underwritten by Vero), Youi NZ Pty Limited.

${ }^{686}$ EQC “How we're settling Kaikōura claims", above n 684. 
of some claims, including all land claims and the building and contents claims of customers who had an open claim from another natural disaster event. ${ }^{687}$ A similar approach was trialled earlier but on a smaller scale following the Valentine's Day earthquake on 14 February 2016 in Christchurch when EQC agreed with Vero Insurance to manage claims on its behalf. 688

Fifteen months after the Kaikōura earthquake, in January 2018, ICNZ issued a press release saying that the Kaikōura earthquake claims were progressing well, and that 88 per cent of all residential claims had been partially or fully settled. ${ }^{689}$

At that time, the total insured losses were noted at $\$ 2,400,000,000$, out of which $\$ 631,000,000$ was paid for residential claims. ${ }^{690}$

There do not appear to have been many multi-unit building claims arising out the Kaikōura earthquake. This reflects the geographical location of the earthquake. The most significant damage was caused to rural areas, where there were no multi-unit buildings. A number of Body Corporates were affected in Wellington, but it seems not to have been to the same extent as in Christchurch. In response to a question in the online survey, ${ }^{691} \mathrm{ICNZ}$ indicated that its member insurance companies received approximately 135 multi-unit building claims. This number included claims for retirement villages, which at the time were still subject to the research. While the number of multi-unit building claims is small, the experience is nevertheless valuable and informative as it provides a point of comparison with the Canterbury earthquakes.

The main points of difference between the Canterbury earthquakes and the Kaikōura earthquake are set out below.

\footnotetext{
${ }^{687}$ EQC <www.eqc.govt.nz>.

${ }^{688}$ Acuo, above $\mathrm{n} 457$ at 3.

${ }^{689}$ ICNZ <www.icnz.org.nz>.

${ }^{690}$ ICNZ "Kaikōura earthquake claims progressing well” (25 January 2018) <www.icnz.org.nz>.

${ }^{691}$ Online survey ICNZ.
} 


\section{$1 \quad$ No dual handling of insurance claims}

EQC handed the management of their claims to a number of insurance companies so, to a large extent, there was no dual handling of claims. This was a success, and it facilitated a faster resolution of insurance claims. ${ }^{692}$

\section{Single event}

The Kaikoura earthquake was a single event rather than multiple events. In contrast with Canterbury, once the shaking stopped, repairs were able to start.

\section{Sum Insured environment}

The Kaikōura earthquake happened within a Sum Insured environment, where each property had a clearly stated limit of cover, as opposed to an open-ended cover available in Canterbury. IAG was of the view that this "greatly simplified the settlement of badly damaged homes; reduced the level of disputes and presence of advocates; and provided greater certainty to homeowners."693

\section{Existing infrastructure and knowledge}

Given the Kaikōura event happened in relatively close succession to the Canterbury earthquakes, the insurers were able to use some of the procedures they had in place for the

\footnotetext{
${ }^{692}$ Focus Group discussion; Interview with Residential Risk Analysis; Online survey ICNZ; Online survey insurance companies; Interview with RAS; Online survey lawyers.

693 IAG New Zealand "Submission on Insurance Contract Law Review", above n 440 at 29 <www.iag.co.nz/>.
} 
Canterbury earthquakes, as well as applying their previous experience. This assisted with a speedier resolution of claims.

\section{Cash settlements}

Finally, it appears that cash settlements became the default method of settling insurance claims. ${ }^{694}$ That significantly reduced the time to bring an insurance claim to conclusion.

It was difficult to find information specific to the Kaikōura multi-unit building claims. When I interviewed or surveyed people about the Canterbury and the Kaikōura earthquakes together, interviewees just focused on Canterbury. It became clear that the Canterbury event overshadowed Kaikōura.

Most of the people interviewed (especially lawyers) had not been involved with the Kaikōura earthquake at all. That suggests that claims were not as complicated and perhaps the lawyers' advice not needed.

To obtain more information, I decided to approach the largest insurance company in New Zealand with some written questions, specific only to the Kaikōura multi-unit claims. This was more successful in gaining information.

In summary, the response ${ }^{695}$ was that there were few multi-unit building claims. Where damage occurred, it was largely repairable and there were no total losses. This insurer's experience was that none of the multi-unit buildings had damage to the foundations. It appears that major repair dependencies were not triggered.

The agency agreement with EQC was beneficial and significantly shortened the time to decide claims, as it avoided a double assessment and delays in transitioning the claim from EQC to the private insurers. Most claims were under the EQC cap.

There were larger excesses applicable (having been increased following the Canterbury earthquakes) and this assisted with settlement. It was not clear to me how they assisted, but

\footnotetext{
${ }^{694}$ IAG New Zealand "Submission on Insurance Contract Law Review", above n 440 at 29 <www.iag.co.nz>. ${ }^{695}$ Written interview questions (Q \& A style) with IAG New Zealand (Emma Gabor, Wellington, July 2019).
} 
presumably the settlement amounts were smaller, meaning the claims could be handled by more junior people in the team and did not require senior clearance, or because the assessment of loss was within the excess.

As there were no total losses reported, the Sum Insureds for multi-unit buildings were not tested. Unfortunately, that means that the research is not able to draw any lessons related to underinsurance. That is unfortunate.

A significant difference was that most, if not all, insurance companies seem to have resolved the Kaikōura claims via cash settlements. There was no reinstatement programme, and the insurers did not get involved with the repairs. Of course, a cash settlement approach was always going to be faster than a reinstatement programme. A specific question asked if homeowners were unhappy about being cash settled, but that does not appear to have been the case. Reportedly, most people were content to engage their own builder, especially Body Corporates, which had existing relationships with construction professionals and wanted to use their own consultants anyway. It is possible that this reported acceptance of cash settlements was due to the fact that none of the claims were a total loss or required significant structural repairs. It is unclear whether a cash settlement would have been as well received by a group of cross-lease owners who then had to engage in a rebuild of the units on their own.

There has been little or no upset mentioned in the media in relation to how insurers handled insurance claims arising from the Kaikōura earthquake. However, it does not mean everyone was satisfied. During the Public Inquiry into the Earthquake Commission, an update from the Chair reported that: ${ }^{696}$

The Inquiry heard from a number of people whose EQC claims were managed by their private insurer following the Kaikōura/Hurunui earthquakes. People reported mixed experiences. Some were very happy and compared it favourably to their Canterbury experience. Others reported poor communication and the feeling insurers were

\footnotetext{
${ }^{696}$ Silvia Cartwright Public Inquiry into the Earthquake Commission: In the People's Voice - a Snapshot of What the Inquiry Has Heard (online ed, December 2019) <www.eqcinquiry.govt.nz> at 4.
} 
drawing out the process to 'wear them down'. Private insurers were positive about the insurer-led approach.

One homeowner said: ${ }^{697}$

Dealing with the private insurers is really no different from EQC. You are basically told you don't know anything and offered a pittance to take and walk with no structural reports or geotechnical advice.

There were mixed responses to the agency-based initiative to have private insurers manage claims on behalf of EQC. It is unclear how widespread this kind of response was.

The cash settlement approach meant that the insurers did not have to face any of the human issues, did not have to deal with neighbouring disputes (if any), or underinsurance or noninsurance on site, or defective titles.

There were no reported cases of on-selling or assignments, possibly because the claims settled much quicker.

In relation to technical issues, the only thing that was mentioned was dealing with preexisting issues. It appears there were a few properties that had suffered damage in previous insured events, so there had to be an assessment on what new damage was caused. ${ }^{698}$ This point was not elaborated but it is possible to refer to Body Corporate claims in Wellington from the 2013 Seddon earthquake that might have still been unresolved.

\section{F $\quad$ Risks Outside Natural Disasters}

The study has been unable to find issues with multi-unit building claims prior to the Canterbury earthquakes. One or two interviewees could recall some isolated claims, but they were not problematic, mostly because the damage was partial and did not affect main

\footnotetext{
${ }^{697}$ Cartwright In the People's Voice, above n 696 at 4.

${ }^{698}$ Interview with EQC.
} 
structural elements such as foundations. It might have been fire or water damage that affected common walls or roofs. ${ }^{699}$

EQC could not recall any issues with multi-unit building claims prior to the Canterbury earthquakes either but justified it on the basis that: ${ }^{700}$

EQC was never set up to run a repair program, so everything was cash settled prior to the Canterbury event. ... Cross-lease properties probably were just cash settled on an individual basis.

If EQC cash settled those claims, it did not have to contend with the human element and the difficulties of reinstating the properties.

The lack of previous issues was surprising. It asked for investigation. What was so special about the Canterbury earthquakes that made multi-unit building claims so complex? The research identified three aspects.

First, the Canterbury earthquakes were more powerful and destructive than other events, and they triggered major repair dependencies, including damage to the foundations. It is likely that, in the past, events were not as destructive to trigger major repair dependencies.

Second, Christchurch is an urban centre with thousands of multi-unit buildings. It has the second highest number of cross-lease properties in the country (over 32,000 titles) and the third highest number of unit titles (over 12,000). This resulted in a landslide number of multi-unit building claims, not something that the country had experienced before.

Third, the resolution of claims in Canterbury took longer than usual due to the ongoing aftershocks (when work was not able to start) and later due to the insurance companies finding it difficult to resolve these claims. This gave an opportunity for the human element

\footnotetext{
${ }^{699}$ Interview with Residential Risk Analysis; Interview with EQC.

${ }^{700}$ Interview with EQC.
} 
to manifest itself. By the time it came to a repair, owners were well into the Disillusionment Stage, which is characterised by disillusionment, self-centredness, and a loss of community spirit. Resolving insurance claims for a multi-unit building requires a united approach (decision dependency) and this was difficult to achieve in the Disillusionment Stage.

Before I conclude on this, I need to mention one example of a problematic multi-unit building claim outside natural disasters (and which happened after the Canterbury earthquakes). ${ }^{701}$ This was a small claim for water damage to a ceiling. The property was a townhouse in a fee simple development. The insurer investigated the cause of the water entry and found that water was coming through a hole in the roof over another unit, two numbers down. The units were insured with separate insurers. In this case, the insurer was not able to repair the hole in the roof because it did not have a legal basis for undertaking repairs to the roof of a property it did not insure. It said that all it could do was to repair the water damage to the ceiling and leave it to the owner to discuss with the neighbour about the roof being repaired. The insurer also excluded all further water damage to the ceiling, as this was now a known issue and therefore no longer accidental. This situation highlights some of the difficulties created by the repair dependencies, which can lead to civil disputes.

\section{G Summary}

Some of the findings coming out of the study are surprising. At the start of the research, it was natural to expect that some blame would be put on resourcing issues such as lack of engineers and loss adjusters, or insurance companies in general. While there were a few mentions of a lack of engineers, in particular geotech engineers, the focus of the responses was completely different. Most people referred to the human element as the primary difficulty in resolving multi-unit building claims. Neighbour disputes seem to have affected

\footnotetext{
${ }^{701}$ Interview with Chair of the ICNZ Personal Lines Committee.
} 
a number of claims. Unclear property rights gave rise to civil disputes. This had the effect of obstructing the resolution of insurance claims.

There were fewer problems for Body Corporates. For Body Corporates, the main issue was underinsurance. $^{702}$ This affected many Body Corporates in Christchurch. This created problems for the unit owners as money was not available to carry out the repairs. This in turn led to the Body Corporates trying to find alternative ways of extending the limited insurance cover. This led to protracted litigation and significant impact for homeowners who were in limbo for many years. At the time of writing the thesis, ten years after the first Canterbury earthquake, there are still Body Corporate claims going through the courts. ${ }^{703}$

Small Body Corporates that did not have a Committee and proper functioning experienced problems similar to cross-leases as owners were unable to make decisions in a unified way.

The Canterbury and the Kaikōura earthquakes provided invaluable insight into insurance claims for multi-unit buildings. In Canterbury, all insurance claims were difficult, but multi-unit buildings presented further challenges.

Insurers discovered that units were not able to be repaired without affecting the other units, and that owners had to adopt a whole-of-building approach. This was no more than a consequence of the repair dependencies.

The technical difficulties in finding a repair methodology meant that often an owner's right of reinstatement would interfere with the rights of the other owners. Owners found themselves having to come together and make collective decisions. This was easier for Body Corporates and company share schemes, where owners knew their rights, there was

\footnotetext{
${ }^{702}$ Interview with Young Hunter; Interview with Grant Shand Barristers and Solicitors; Finn Legal Response to Natural Disasters, above n 7 at 325.

${ }^{703}$ As of 18 June 2021, there were 100 active cases on the Christchurch High Court Earthquake Litigation List, out of which eight involve Body Corporates <https://www.courtsofnz.govt.nz/assets/5-TheCourts/high-court/high-court-lists/earthquake-list-christchurch/20210618-Christchurch-HC-Earthquakelitigation-list.pdf $>$.
} 
a governance structure providing administrative leadership and there was a pre-determined way of making decisions through voting.

The problem was more acute for cross-leases and fee simple townhouses where owners expected to be able to make decisions independent of each other. It was difficult to move them from their original expectations. They also had multiple insurers on site, multiple policies and different levels of cover, and multiple decision-makers. And even when they understood the circumstances and were willing to commit to a joint repair effort, there was no pre-determined way for making decisions. Who takes the lead? Whose ideas take priority? What to do when one owner disagrees or is unable to commit?

The uncertainties led to civil disputes. Insurance companies were not equipped to resolve the property disputes between the owners, nor was it their place. Some insurers made efforts to work with the owners involved, even brought in lawyers to explain their legal rights and obligations, ${ }^{704}$ but, at some point, they gave up and moved toward settling claims in cash and leaving the owners to resolve their differences. ${ }^{705}$

\footnotetext{
${ }^{704}$ Interview with DLA Piper; Interview with Residential Risk Analysis.

${ }^{705}$ Interview with EQC; Interview with Nine Dots; Interview with Residential Risk Analysis.
} 


\section{PROPOSED SOLUTIONS}

This next chapter distils the learnings from the Canterbury and the Kaikōura earthquakes and proposes solutions for the future. How do we address the human element? Is there a better way of allowing for the repair dependencies? Can insurance companies improve their processes?

The thesis proposes several changes. They fall into three categories: property law measures, insurance industry measures, and educational measures.

\section{A Property Law Measures}

The thesis recognises that property disputes have a significant impact on resolving insurance claims. Thus, it makes significant recommendations in improving the way we build, manage, and insure multi-unit buildings.

For new buildings, the change focuses on the way we build going forward, concentrating on addressing the repair dependencies.

For existing buildings, the change focuses on improving the existing property framework, with a view of facilitating decision dependencies. To improve the existing property framework, three reforms are proposed. The first is to impose a governance structure on cross-leases and fee simple townhouses with significant repair dependencies; the second is to introduce compulsory common insurance for these properties; and the third is to adopt Administrative Rules to better facilitate management of existing multi-unit buildings. The Administrative Rules are to imply terms in existing covenants, provide guidance on repairing properties in close proximity of each other, and introduce better dispute resolution mechanisms. 


\section{$1 \quad$ New multi-unit buildings}

The thesis posits that, to avoid repair dependencies, there needs to be a change in the way multi-unit buildings are built. It makes two proposals in relation to new multi-unit buildings. It divides the suggestions according to the typology of construction. For properties built strata style, the thesis posits that they should only be developed under a Body Corporate structure and subject to the UTA. For properties built townhouse style (that is, side by side as opposed to layered horizontally), the thesis posits that they should be built with no repair dependencies. Property developers should adopt resilient building techniques to ensure that each unit can be repaired in isolation of each other. If there are facilities to be shared, these could be common property under the control of an incorporated society of owners, although the homes themselves should be built with no repair dependencies. If property developers wish to build townhouse style but with shared elements, they should do so under a unit title structure.

\section{Strata style properties should be unit titles}

Strata style properties are generally one building divided into flats. There is one foundation and normally one building envelope (four exterior walls and a roof). The repair dependencies are so significant that nothing short of treating them as one building will be sufficient to enable good management of such buildings and the communities within.

For example, one interviewee referred to a situation where there were six cross-lease units. $^{706}$ The three units upstairs were owned by three young men who had Full Replacement insurance, but the three units downstairs were owned by two women who were underinsured. The foundation was damaged, so all the units had to be demolished and rebuilt. There was no way of making decisions together. Each owner had their own insurance cover. There was no process to make owners cooperate with each other. One of the women downstairs refused to engage with the rebuild process. In the end, the three men had to sell their land shares at a discount, so they could move on and look for another place

\footnotetext{
${ }^{706}$ Interview with Residential Risk Analysis, discussed in Chapter IV, Part C6.
} 
to live. The situation exemplifies what happens when flats in a strata development are treated and managed as individual buildings.

Another example received in an interview ${ }^{707}$ was that of a homeowner who was part of a community of ten cross-lease owners. The units were built strata style (five upstairs, five downstairs). Each had their own insurance arrangements, and some were underinsured. There was foundation damage, which required a complete rebuilt of the units. Because of the way in which the units were constructed, all the units had to be demolished and rebuilt together. The insurance companies refused to involve themselves with the reinstatement process because some of the owners were underinsured and there was no certainty of funds to complete the joint project. The owners had to consider whether they could organise themselves to carry out the project. The lack of a governance structure meant it was too hard to achieve consensus and enter into contracts. In the end, they abandoned the rebuild and sold the damaged units to a developer. Even the sale had to be agreed by all the owners because the developer would only buy them together. In a similar case, one owner refused to agree to the sale, and the owners had to go to Court to break the deadlock. ${ }^{708}$

I could not find any examples of fee simple strata units in Canterbury and the research shows they some have developed in the last few years (post-Canterbury) such as FSST titles. ${ }^{709}$ However, they would have similar issues unless they have a governance body and the units are managed as one building and are insured together.

The thesis posits that any properties built strata style should be under a unit title mechanism because this type of title benefits from legislative provisions to enable a better management of a strata community.

Unit titles have been intentionally created by legislation for the purpose of facilitating community living. The rights and obligations are clearly set out in the statute, and there is a framework for their operation and for dispute resolution.

\footnotetext{
${ }^{707}$ Interview with Homeowner 2, partly discussed in Chapter IV, Part C2 and C6.

${ }^{708}$ Rozee $v$ Zhang, above n 551.

${ }^{709}$ See discussion in Part II C4.
} 


\section{Townhouses should have no repair dependencies}

As for the properties built townhouse style, the thesis recognises that there are benefits in having medium and high-density housing and promoting good stewardship of productive land. Thus, it does not suggest that New Zealand moves away from medium and highdensity housing, but it suggests this can be achieved by resilient building, where units are built close to each other or next to each other but on separate foundations and with separate building envelopes. This is similar to the way commercial properties are built in the central business district: next to each other to maximise the use of the land, but with their own building elements so they can be repaired or replaced independent of each other. Certain types of construction materials (such as weatherboard cladding) necessitate maintenance and might require a metre clearance between units for access. Other materials such as concrete slabs do not require maintenance and units could be build touching each other.

The thesis submits that new cross-lease properties, fee simple townhouses, and company share schemes should not be built with repair dependencies.

I have included company share schemes in this proposal, although, so far, they seem to have functioned adequately. The reason for their inclusion is threefold. First, there was limited feedback from Canterbury and Kaikoura, so it is better to be cautious. Second, the titles rely on the developer to set up the right management process in the constitution so they are not subject to rigorous legislative provisions. Going forward, it is better that they align with cross-leases and fee simple townhouses in the way they are built. Third, the Law Commission, while acknowledging that company share schemes seem to have functioned satisfactorily, recommended that no new company share schemes be created. ${ }^{710}$ Requiring them to comply with the same conditions applicable to cross-lease and fee simple will make it less attractive to developers to revert to this type of property structure. I do not wish to create a circumstance that would give company share schemes an advantage over the other types of titles and end up inadvertently promoting them.

\footnotetext{
${ }^{710}$ Law Commission, above at n 44 at [3].
} 
Coming back to the proposal that multi-unit buildings should not have repair dependencies, this is grounded in the Canterbury experience. It is clear that repair dependencies lead to significant collateral damage. Collateral damage creates two problems: first, it creates disputes about who is responsible for paying for it; and second, it leads to unnecessary displacement of owners.

\section{Collateral damage and the issue of costs}

I deal with the responsibility for cost first. In Canterbury, during the Shared Property Project the insurers had to decide how to deal with collateral damage - where an undamaged flat (say flat A) had to be demolished or damaged in order to repair a neighbouring flat (flat B). The insurer of flat A had the right to refuse to pay if flat A was damaged simply in order to carry out the repairs to flat B. They had the right to argue that the damage to flat A was not accidental, and therefore not insured. Because it was a complicated issue that only added to an already complicated claim, the insurers decided to let the losses lie where they fell, and each insurance company paid for the flat they insured. ${ }^{711}$ The insurers were able to do that because, during the Canterbury earthquakes, most cross-lease owners had Full Replacement insurance, which meant there was no monetary limit on their policies. The insurers were therefore able to implement this agreement.

However, New Zealand has now moved to a Sum Insured environment, where owners mostly have a monetary limit on their policies. As discussed in Chapter III, I believe that homeowners do not have sufficient knowledge and tools to set the Sum Insured at an adequate level, and we are likely to see an increase in underinsurance going forward. That means, if another Shared Property Project is needed, insurers might not be able to be as generous because the monetary caps will be insufficient.

So, for example, if owner A sets the Sum Insured at \$350,000 and suffers repairable damage of $\$ 200,000$, owner A will have sufficient money to repair their unit. But if unit B in the middle of the row has a crack in the foundation, and this causes a complete rebuild of Unit B and all the adjacent townhouses including Unit A, and the cost to rebuild is

\footnotetext{
${ }^{711}$ Interview with Young Hunter.
} 
$\$ 500,0000$, owner A is not able to pay because their Sum Insured is too low. The question will then be who will pay the additional cost (the difference of $\$ 300,000) ?^{712}$ Is it the owner of unit B who has the crack in the foundation? And what happens if there are four other units affected in the same way? Will unit B be required to pay $\$ 1.2 \mathrm{~m}^{713}$ in collateral damage plus the $\$ 500,000$ for the rebuild of their own unit?

The reality is that most homeowners will not think to allow for collateral damage in their Sum Insured. But owners who live in houses with repair dependencies have an increased risk of collateral damage cost. The higher the dependency factor, the more they need to increase their Sum Insured.

Given the likelihood that unit B will not have sufficient insurance to cover all the collateral damage, it is easy to see how a property dispute will follow. Clever lawyers will argue that the common foundations or other common building elements are for the benefit of all owners, and so everyone should be contributing. This might be a valid argument and worth raising, but it will not assist with quick and efficient reinstatement of the properties. In fact, it will lead to civil disputes, repeating the predicament seen in Canterbury.

Some insurers currently see the collateral damage issue as a "can of worms", ${ }^{714}$ which suggests that, if the issue arises, there might be disagreements at insurer level as well. This will create further delays.

\section{Collateral damage and displacement of people}

The second problem created by collateral damage is the human cost of displacing families from their homes to carry out repairs. If one unit suffers damage and the repair necessitates demolition of neighbouring units, this will have a flow-on effect on the other people in the development.

\footnotetext{
712 The difference between the rebuild cost of $\$ 500,000$ and the repair cost of $\$ 200,000$.

713 Assuming 4 units $x \$ 300,000$ difference in cost.

${ }^{714}$ Interview with Chair of the ICNZ Personal Lines Committee.
} 
Interviewees spoke about fee simple townhouses linked by common shared elements where repairs necessitated joint efforts with the other neighbours. ${ }^{715}$

The human cost cannot be underestimated. EQC warned that the cost of social dislocation and economic disruption can be many times greater than the direct cost of repairing the physical damage. ${ }^{716}$

One of EQC's disaster resilience visions for 2019-2029 is that engineers, architects, developers, and builders understand the value of incorporating damage-limiting design in buildings, to ensure the building stock becomes more resilient with time. ${ }^{717}$ I believe requiring new multi-unit buildings to have separate building envelopes is a way of building more resilient housing stock.

At the very least, new cross-lease properties, fee simple townhouses, and company share schemes should not have common foundations. Common foundations create significant repair dependencies, which can lead to deadlock situations, so these should be avoided as a minimum. The thesis, however, goes one step further to argue for an ideal situation where units are contained within their own building envelope.

If new multi-unit buildings are built in a resilient way, they do not require a governance structure because owners do not need to make decisions together. They can insure the units separately because there are no repair dependencies. In effect, these buildings will no longer be multi-unit buildings because they will no longer have repair and decision dependencies. However, they will still benefit from the adoption of Administrative Rules which I discuss below.

\section{New developments with resilient multi-unit buildings but with common facilities}

There will be situations where large, new developments wish to share facilities such as parks, reserves, BBQ areas, parking lots, and the like. In that case, the development should provide for an incorporated society of owners to manage the common property. The

\footnotetext{
715 Interview with Young Hunter; Interview with RAS.

${ }^{716}$ EQC Resilience Strategy, above n 415 at 3.

${ }^{717}$ EQC Resilience Strategy, above n 415 at 6.
} 
governance body should be subject to the three property law reforms set out below in the thesis.

Just to clarify, the homes themselves should still be built in a resilient manner. This would ensure that damage to the homes can be repaired quickly and efficiently without the need to consult the other owners. Only the common property (subsidiary buildings and facilities) would require common decision-making, but their reinstatement will have a lesser impact on the owners' living arrangements. Their damage will create a loss of amenity rather than loss of a home.

In addition, the existence of a governance body will ensure good management of common property, and facilitate common decision-making.

If the only shared property is a driveway, there is no need to create a governance structure because shared driveways can be adequately managed within the current legislation and through private easements.

If a developer wishes to build new townhouses with common foundations and shared walls, then the properties should be unit titles and subject to the provisions set out in the UTA. There is still a way to build with repair dependencies, but under the provision and protection of a statute so the properties can be managed properly.

\section{How can this be achieved?}

The thesis proposes that the government introduces legislation to preclude construction of new cross-lease properties, fee simple townhouses, and company share schemes that have repair dependencies. One way to achieve this could be through amending the Building Code. $^{718}$

The Code already requires, among other things, that buildings have a low probability of causing loss of amenity during alteration. ${ }^{719}$ It also stipulates that account shall be taken of all physical conditions likely to affect the stability of buildings, including any adverse

\footnotetext{
718 Building Regulations 1992, Schedule 1.

${ }^{719}$ Building Code, cl B1.3.2
} 
effects due to insufficient separation from other buildings ${ }^{720}$ and removal of support. ${ }^{721}$ The Code goes some way to providing parameters for construction of buildings in close proximity of other buildings.

There could be an amendment to Clause B1 of the Building Code, which sets standards for the structure of buildings, to stipulate that units in a multi-unit building that are intended to be developed under a cross-lease, a fee simple title, or a company share scheme should have their own independent building envelope. Alternatively, the Building Code could introduce a separate requirement for repair resilience, in the same way it stipulates requirements for durability, ${ }^{722}$ fire safety, ${ }^{723}$ or energy efficiency. ${ }^{724}$ This could provide the objectives of the new standard, the functional requirements (the level of separation needed), and how compliance with the Code could be achieved.

MBIE often reviews the Code to ensure that it keeps pace with innovation, new construction methods, and the changing needs of our society. ${ }^{725}$ In 2021 , for example, MBIE sought to introduce acceptable solutions and verification methods for improving natural light in high-density housing. ${ }^{726}$ So it appears that the government updates the building standards as the need arises, and it can do the same to address repair dependencies in multi-unit buildings.

It is not crucial that amendments be made through the Building Code. A policy adviser with experience in legislation drafting might be able to suggest a more suitable legislative vehicle to achieve the desired effect.

\footnotetext{
${ }^{720}$ Building Code, cl B1.3.3(o)

${ }^{721}$ Building Code, cl B1.3.3(r).

722 Clause B2.

${ }^{723}$ Clauses $\mathrm{C} 1$ to $\mathrm{C} 6$.

${ }^{724}$ Clause H1.

725 MBIE Building Performance - Consultation document (ISBN 978-1-99-001996-8, online ed, 6 April 2021) <www.mbie.govt.nz/dmsdocument/13808-consultation-document-building-code-update-2021> at 2.

${ }^{726}$ MBIE Building Performance - Consultation document, above n 725 at 41 .
} 


\section{Existing housing stock: The guiding principle in finding the solutions}

As for existing housing stock, we cannot change the repair dependencies. Therefore, we must find solutions that address the decision dependencies.

The thesis argues that the starting point in finding solutions is to recognise multi-unit buildings for what they are: communities. It is not until we grasp this that we begin to understand what multi-unit building communities need, and what solutions could be proposed.

The idea of multi-unit buildings as communities is not new. The UTA specifically states that the purpose of the Act is to create a framework of ownership by communities of individual owners. ${ }^{727}$

One scholar cautioned that we need to be careful that we treat unit holders as members of a community of owners rather than individuals who happen to live in a collective setting. ${ }^{728}$ Indeed, there is a difference between a member of a community and an individual who happens to be part of a group of owners in a particular location. The expectations of an individual (for self-determination and independent decision-making) would be different to the expectations of a community member (where the interest of the group prevails).

When more than one person owns or has the right to use property, "property law must determine how decisions ought to be made in a way that allows productive collective decisions while protecting the interests of individual decision makers." 729

\footnotetext{
${ }^{727}$ UTA, s 3.

${ }^{728}$ France-Hudson, above n 239.

${ }^{729}$ Peter M. Gerhart Property Law and Social Morality (Cambridge University Press, Cambridge, 2014) at 212.
} 
The home is usually a person's most expensive asset, so it is important that owners have clear and enforceable property rights. One scholar pointed out that "the more valuable the resources at stake, the clearer and more secure the property rights should be". ${ }^{730}$

And when it comes to communities, the rights are to be exercised through a properly structured organisation without which the community of owners cannot function effectively. ${ }^{731}$

Four broad themes emerge from the guiding principle of community. The first one is that communities benefit from administrative leadership; the second is that where there is common property, there must be a way of making decisions together; the third is that the rights must be clear and easy to enforce; and the fourth (which naturally follows the first three) is that there needs to be a process for resolving disagreements. The insurance aspect seems to stand alone but it forms part of the good management matrix.

\section{Existing housing stock: Some important carveouts}

The thesis puts forward three property law reforms to enable a better administration of existing multi-unit buildings. The first is to impose a compulsory governance structure; the second is to impose compulsory common insurance; and the third is to pass legislation that would enable better management of multi-unit buildings.

Before I move on to the proposals for reform, I need to clarify that some of the measures proposed do not apply to three specific groups of multi-unit buildings. The first carveout is in relation to existing unit titles and company share schemes; the second is in relation to

\footnotetext{
${ }^{730}$ Carol Rose Property and Persuasion: Essays on the History, Theory and Rhetoric of Ownership (Westview Press, Boulder, 1994) at 3.

${ }^{731}$ CG van der Merwe “Apartment Ownership” (1994) Vol VI International Encyclopedia of Comparative Law at [332] cited in $\mathrm{Lu} \mathrm{Xu} \mathrm{"Managing} \mathrm{and} \mathrm{Maintaining} \mathrm{Flatted} \mathrm{Buildings:} \mathrm{Some} \mathrm{Anglo-Scottish}$ Comparisons" (2010) 14(2) Edinburgh L Rev 236 at 243.
} 
small multi-unit buildings; and the third is for buildings with minor or no repair dependencies.

\section{Unit titles and company share schemes}

First, the thesis does not propose any changes to the way existing unit titles and company share schemes are managed or insured but it makes one important note. This is that the thesis supports the current proposals for the strengthening of the Body Corporate governance. ${ }^{732}$ This is incredibly important. Owners must be empowered to make decisions and manage the community affairs in a way that is speedy, fair and responsible.

The experience from the Canterbury earthquakes showed that Body Corporates coped appropriately with the repair and the decision dependencies. ${ }^{733}$ As for company share schemes, there was little feedback from the Canterbury and the Kaikōura earthquakes, so I assume they coped in a similar manner with Body Corporates because they operate on similar premises. Company share schemes and most Body Corporates manage their units as one building for the purposes of maintenance and insurance. Thus, the repair dependencies are addressed. The decision dependencies, when engaged, can be exercised through voting. The voting process is prescribed in the constitution (for company share schemes) or through the legislation (for unit titles).

Both types of multi-unit buildings have governance structures. The unit titles have a Body Corporate that can, and often does, delegate its responsibilities to a Committee of owners. Company share schemes have a governance structure in the form of a Board of Directors.

They also have relatively clear management rules by the application of the constitution and of the legislation, respectively, and these support the administration of the community.

While the thesis does not suggest any changes to the existing company share schemes, it suggests that going forward these buildings are either built under a unit title structure (if strata style) or as resilient buildings that can be repaired independent of each other.

\footnotetext{
732 See discussion in Chapter II, Part F.

${ }^{733}$ With the exception of small, dysfunctional Body Corporates without a Committee.
} 


\section{Small multi-unit buildings}

Second, the thesis does not propose imposing a governance structure and compulsory common insurance for multi-unit buildings with five or fewer units.

I acknowledge that the UTA threshold for Body Corporates needing a Body Corporate Committee is ten units. However, the UTA imposes rules for and creates a Body Corporate structure for all developments, including small Body Corporates, so I believe the situation is slightly different. I also believe that cross-leases and fee simple developments with more than five units are difficult to manage.

One homeowner was in a group of ten cross-lease units and the owners could not agree what to do with the building. ${ }^{734}$ An authoritative textbook on land law in New Zealand lends support to this position by saying that "[c]ross leases are commonly thought to be unwieldy in developments of more than four to six titles" well when four to six flats are involved, the cross lease mechanism has proved cumbersome for larger developments." ${ }^{, 736}$ Insurers have also found that up to five units are manageable without a Body Corporate structure but larger developments are not. ${ }^{737}$

It appears that the more units involved, the harder it is to get a collective decision. I therefore suggest that five should be the threshold between what is considered a small multi-unit building as opposed to a large multi-unit building.

Scholars have criticised imposing heavy administration duties on small unit titles. ${ }^{738}$ Indeed, there must be a balance between good governance and excessive administration.

More research is necessary to determine whether small unit titles, small cross-lease properties, and small fee simple townhouses should be subject to compulsory governance

\footnotetext{
${ }^{734}$ Interview with Homeowner 2.

735 Thomas, above n 142 at 1140 .

736 Pidgeon and Tappenden, above n 88 at 1216.

${ }^{737}$ Interview with Chair of the ICNZ Personal Lines Committee.

${ }^{738}$ Finn, France-Hudson and Toomey, above n 239 citing McMorland and Gibbons, above n 133 at 4.18.
} 
and management. The research should examine the additional burden imposed by excessive administration. Such research is beyond the parameters of this thesis, which primarily examines the experience from the Canterbury earthquakes.

In my view, where Body Corporates do not have a Committee, they have more risk of problems with resolving their insurance claims. ${ }^{739}$ This points to a need, even for small multi-unit buildings, to have an active governance structure. The research should also consider the recent changes in the insurers' attitude toward multi-unit buildings that do not have a Body Corporate structure. ${ }^{740}$ Developments with five or fewer units might not be able to secure insurance for all their assets. It might be that the insurance position will compel owners of small multi-unit buildings to form a governance body anyway.

I would also recommend that the government reconsiders whether the threshold for unit titles which are required to have a Committee should be six units rather than nine. This is for the same reasons applicable to cross-leases and fee simple townhouses (harder to manage without active leadership).

Finally, an exception to the carveout. While small multi-unit buildings should be exempt from the first two property law reforms, they would benefit from the third reform and should be subject to legislative provisions that improve the management of multi-unit buildings. I discuss this in more detail under Administrative Rules below.

\section{Buildings with no repair dependencies or minor repair dependencies}

Finally, the third limitation is in relation to multi-unit buildings that have minor or no repair dependencies.

As discussed in Chapter II, it is possible to have multi-unit buildings with no repair dependencies. The thesis refers to these situations as title-driven multi-unit buildings because the decision dependencies do not arise out of repair dependencies but rather from

\footnotetext{
${ }^{739}$ Interview with Young Hunter; Interview with RAS; Interview with Residential Risk Analysis.

${ }^{740}$ ICNZ "Caution”, above n 11.
} 
stipulations on the property title. Such situations for example are standalone unit titles and standalone cross-lease properties. Because of the provisions in the UTA or in the Memorandum of Lease, the owners might be required to consult with the other owners and make decisions together in relation to reinstatement.

The thesis does not propose changing the status quo in relation to these buildings but proposes that legislation be passed to make it easier to convert standalone cross-leases to fee simple and release owners from the decision dependency burden where this is not needed. These proposals are set out ahead in this chapter under the heading "Some recommendations specific to cross-lease properties".

As for cross-lease properties and fee simple townhouses that have minor repair dependencies (such as party walls and common roofing elements) the thesis proposes a split solution. The thesis suggests that they are not subject to the first two property law reforms (that is, they should not be obliged to have a governance structure or common and compulsory insurance) but should be subject to the last reform which recommends improved legislative provisions to facilitate the management of existing multi-unit buildings.

\section{Existing housing stock: Three property law reforms}

Coming now to improving the existing property framework, the thesis proposes three reforms. The first is that large cross-lease properties and fee simple townhouses with significant repair dependencies should have a governance structure. The second is that these properties also have compulsory common insurance. The third is that legislation should be passed to facilitate better management of existing multi-unit buildings.

\section{Governance structure}

The first reform is to impose a compulsory governance structure on existing large crossleases and fee simple townhouses that have significant repair dependencies. As discussed already, significant repair dependency means common foundations. Common foundations, 
when damaged, can lead to deadlock situations unless there is a way of making collective decisions about reinstatement.

Powers and limits

The governance body should be, in some respects, like a Body Corporate in that it should be a corporate entity, made of owners, it should keep a register of owners, organise a meeting once a year (unless there is a specific need), oversee decision-making through voting, and organise joint insurance for the units.

The governance body should have delegated authority to bind owners, to enter into contracts, and to apply the insurance money toward reinstatement.

The governance body's jurisdiction should only be engaged in matters related to the shared elements of the building.

Finally, the governance structure should be limited to the units that physically share construction elements. Thus, for example, if there is a fee simple development of say 40 units, and they are built in four precincts of ten townhouses each, there should be a governance body for each of the four precincts. There is no need to link 40 owners and require them to make decisions together where there are no repair dependencies between them.

The proposed governance structure would be lighter than a Body Corporate. Body Corporates have extensive powers and duties under the UTA, ${ }^{741}$ including powers and duties related to assignment and reassessment of ownership interests and utility interests, ${ }^{742}$

\footnotetext{
${ }^{741}$ Some of these are listed in s 84 UTA.

${ }^{742}$ Sections 40-42 UTA.
} 
acting as agents for unit owners who lease or licence their units; ${ }^{743}$ sign documents on behalf of owners; ${ }^{744}$ establish a long-term maintenance plan; ${ }^{745}$ impose levies to support the long-term maintenance plan; ${ }^{746}$ spend, borrow or invest money $;{ }^{747}$ grant easements or enter into covenants on the whole or any part of the common property, or over any unit or land that is not common property. ${ }^{748}$ The list is not exhaustive.

The UTA starts from the position that a body corporate may do anything a natural person of full age and capacity may do except as provided for in the UTA or other Acts, ${ }^{749}$ the only limitation being that the Body Corporate's acts must be for the purpose of performing its duties or exercising its powers. ${ }^{750}$

By contrast, the thesis proposes that the newly created governance structures for crossleases and fee simple townhouses have a clearly defined number of powers and duties. The proposed powers and duties are: to call annual meetings; to call special meetings if the need arises; to make decisions through voting; to impose levies for insurance premiums; to apply the insurance money toward reinstatement (unless a special majority decides not to); and to keep a register of owners.

\section{How is this to be achieved?}

One way this could be achieved would be either to create a standalone Act for this purpose or for the UTA to be amended to include a new section dedicated to cross-leases and fee simple townhouses. The new Act or the amended UTA should define cross-leases and fee simple townhouses and make provisions for their good management.

\footnotetext{
${ }^{743}$ Section 81 UTA.

744 Section 86 UTA.

745 Section 116 UTA.

${ }^{746}$ Section 121 UTA.

${ }^{747}$ Sections 130 and 131 UTA.

748 Section 62 UTA.

${ }^{749}$ Section 77(2) UTA.

${ }^{750}$ Section 78 UTA.
} 
The new Act or the amended UTA should specify that cross-lease properties and fee simple townhouses with six or more units and that are built with common foundations become an association of owners and must form a governance structure.

The new Act or the amended UTA should specify that developments with five or fewer units may also create a governance structure, which would then become subject to the provisions of the Act. Owners of small cross-lease properties and fee simple townhouses could decide for themselves if there is a benefit in having a governance body (for example, for the purpose of obtaining insurance).

The new Act or the amended UTA should specify the duties and responsibilities of the new governance structure, and the limits of its power.

Is a governance structure necessary?

But is a governance structure really necessary? The thesis argues that it is.

Multi-unit buildings are a collective of owners linked to each other by repair and decision dependencies. Sometimes they are a small community of two or three owners, sometimes they are a large community with hundreds of owners. The larger the community, the harder it is to find homogeneity of interests and ideas. In Canterbury, one of the major obstacles in reinstating properties was that owners had different agendas. ${ }^{751}$ When interviewed, one homeowner highlighted how the reinstatement of their cross-lease flat could not proceed because it would have been a nightmare to organise ten owners. ${ }^{752}$

Where there is no governance body, there is independent decision-making about matters that concern common building elements. Homeowners make their own decisions about

\footnotetext{
751 Online survey insurance companies; Interview with Residential Risk Analysis; Interview with Young Hunter; Interview with RAS; Interview with lawyer (Christchurch, July 2016) cited in Toomey Finn research paper, above n 26 at 20; Small, above n 9.

752 Interview with Homeowner 2.
} 
arranging insurance (or not) or reinstating the property (or not). This independent decisionmaking is at odds with the repair dependencies.

It is possible to gain a fuller appreciation of these issues by considering some examples of multi-unit living overseas.

In Singapore around 80 per cent of the population lives in multi-unit buildings that are similar to our Body Corporates. But these buildings are owned by the government and leased for 99 years. ${ }^{753}$ The government retains a large measure of control of the land and buildings including having a long-term maintenance plan. ${ }^{754}$ What this means is that there is a strong governance system in place. ${ }^{755}$

This is to be contrasted with the situation in Scotland. In Scotland, tenements account for 24 per cent of the housing stock ${ }^{756}$ and are regulated by the Tenements (Scotland) Act 2004. This form of multi-unit ownership has been criticised for "lacking any central management body, which for many other jurisdictions, including England and Wales, has been seen as an essential element in communal ownership." 757

The foundation to the Tenements (Scotland) Act 2004, was a report from the Scottish Law Commission, which pointed out two interrelated failings of the tenement system: ${ }^{758}$

The most serious defect ... is the absence in the existing law of a proper system of management and decision-making.

[This is coupled with] the requirement that decisions be reached unanimously. In practice unanimity is often impossible to achieve. One of the owners may be abroad or otherwise unavailable; or the ownership of a particular flat may be uncertain; or

\footnotetext{
753 "Why $80 \%$ of Singaporeans live in government-built flats" The Economist (online ed, 8 July 2017).

754 Housing and Development Act 1960 (revised in 2004); "5 Things to Know About Public Housing in Singapore" (18 June 2019) <www.gov.sg>.

755 The governing legislation is Housing and Development Act 1960.

756 Royal Institution of Chartered Surveyors (RICS) Working Group on Maintenance of Tenement Scheme Property Final Recommendations Report (Scotland, online ed, May 2019) <www.rics.org>.

${ }^{757}$ Law Commission (United Kingdom) “Commonhold Comparative Research” (Working copy) (online ed, 10 December 2018) <www.s3-eu-west-2.amazonaws.com> at 104.

758 Law Commission (Scotland) Report on the Law of the Tenement (No 162, Scotland, 1998) <www.scotlawcom.gov.uk/files/4512/7989/7476/rep162.pdf>.
} 
again one or more owners may consistently refuse to sanction any form of expenditure. Experience shows that where maintenance requires unanimity it will very often not get done at all. (footnote omitted)

In Scotland, owners cannot be forced to undertake repairs even if the proposed repairs are reasonable. ${ }^{759}$ The United Kingdom Law Commission prepared a comparative research into commonhold, a type of multi-unit property holding. A working copy of that comparative research states that in Scotland: ${ }^{760}$

Data from 2011 to 2013 indicates that $65.8 \%$ of tenement dwellings had disrepair to critical elements, and $39.2 \%$ of tenement dwellings were in need of urgent repair. It is easy to appreciate how owners might find themselves in a situation of deadlock, especially given the relatively small size of Scottish tenement buildings. Owners are likely to have different agendas and opinions on what would benefit themselves and/or the property. If an owner is planning to sell the property in the future, for instance, he or she may be less inclined to invest substantial sums into the property. In one case, it was necessary for an owner to buy the interest of another in order to break the deadlock in relation to works to communal stairs.

The situation described above is reminiscent of the situation in Canterbury: owners having different agendas, getting into deadlock situations, and having to buy the neighbour's property in order to resolve the situation. ${ }^{761}$

Germany had problems with multi-unit buildings in the past. In a comparative study conducted by the United Kingdom Law Commission, the Commission observed that apartment ownership, going back to medieval times, was loosely regulated and did not provide for the establishment of a governance structure or a way to resolve disputes. ${ }^{762}$ The Commission noted that "[a]s a result of the number of disputes generated, apartment buildings became known as 'streithauser' which translates as 'houses of dissent". 763

\footnotetext{
${ }^{759}$ Law Commission (United Kingdom), above n 757 at 104.

${ }^{760}$ Law Commission (United Kingdom), above n 757 at 105.

${ }^{761}$ Interview with Young Hunter.

${ }^{762}$ Law Commission (United Kingdom), above n 757 at 119.

${ }^{763}$ Law Commission (United Kingdom), above n 757 at 119.
} 
Consequently, apartment ownership was expressly prohibited in the 1900 German Civil Code. ${ }^{764}$ Following the Second World War, the acute need for housing led to legislation being introduced in 1951 to allow and regulate apartment ownership. ${ }^{765}$

Multi-unit buildings in New Zealand are a relatively new concept compared with countries such as Germany or Scotland. In Scotland, tenements can be traced to pre-1919. In fact, one fifth of the tenements in Scotland or 467,000 homes are pre-1919. ${ }^{766}$

The Scottish tenements were unregulated for 85 years, until the Tenement (Scotland) Act 2004 was passed. ${ }^{767}$ The Act introduced a management scheme for tenements to supplement the title deeds, and rules to facilitate repairs and maintenance to common property. ${ }^{768}$

One author commented: ${ }^{769}$

There is no doubt that [the introduction of the Tenement Management Scheme] is to be welcomed. It provides a sensible but not radical reform, and a management structure that should avoid the sort of difficulties that have arisen in the past where owners simply dig their heels in or ignore the requirement for maintenance. The great benefit is the definition of scheme property which overrides ownership issues. In the past, murder has been committed in situations where proprietors have been unable to carry out sensible maintenance. Hopefully proprietors will in future use the Tenement Management Scheme to persuade their neighbours rather than some other and more offensive weapon.

\footnotetext{
${ }^{764}$ Law Commission (United Kingdom), above n 757 at 119.

${ }^{765}$ Law Commission (United Kingdom), above n 757 at 119. Germany introduced First Housing Act 1950.

766 RICS Final Recommendations Report, above n 756 at 1.

767 Harold Ledgerwood "The Scottish Tenement: Past, Present and Future" blog post on University of Aberdeen School of Law's website (online ed, 7 February 2020) <www.abdn.ac.uk>; Rabia Islam (Clapham Solicitors, a law firm) "Law of Tenement, The Tenements (Scotland) Act 2004” (online ed, 24 July 2018) <www.davidclapham.co.uk>.

${ }^{768}$ Islam, above n 767.

${ }^{769}$ Robert Rennie "Last Piece of the Jigsaw: An outline of the Tenements (Scotland) Bill and how far it will innovate on the common law" (online ed, 1 March 2004) <www.lawscot.org.uk>.
} 
However, despite the introduction of the Tenement Management Scheme, problems remained. Of particular concern was the critical state of disrepair of the older, pre-1919 tenements. Left to their own decisions, owners were either unwilling or unable to work out a common repair plan. ${ }^{770}$

In 2019, the Scottish Government appointed a working group to report on a framework for repairs and maintenance of tenements. The Working Group produced an interim report and an informative video showing the plight of the Scottish owners. ${ }^{771}$ The owners featured in the video shared stories similar to the owners in Canterbury. It shows that in Scotland, as it was in Canterbury, it is the human element that stops maintenance and repair of buildings.

The Working Group's final report issued in May 2020 recommended radical changes. ${ }^{772}$ Relevant to the thesis, the Working Group recommended a compulsory Owners' Association for each tenement, which they considered was an "essential element" for administration of tenements because it provided leadership, effective decision-making, and the ability of groups to enter into contracts. ${ }^{773}$

The Scottish experience is that without a governance structure and management rules, homeowners are unable to organise themselves. Over time, buildings need repairs and maintenance, and this is difficult to organise without a governance body.

\footnotetext{
${ }^{770}$ RICS Final Recommendations Report, above n 756 at 2.

771 "Voices from Scottish Tenements" <https://vimeo.com/365520796>.

772 RICS Final Recommendations Report, above n 756. They recommended that common or "scheme" property of each tenement is inspected every five years by a qualified professional and a report prepared that would be publicly available to existing and prospective owners, tenants, neighbours and policy makers. The report was to state the condition of each building, the cost necessary to bring it up to standard, and any ongoing maintenance. The Working Group recommended that no tenement flat or building be sold or tenanted without a tenement inspection report. The Group also recommended that a Building Reserve Fund be established to allow for the repairs to be carried out. This is similar to the long-term maintenance fund of Body Corporates in New Zealand.

${ }^{773}$ RICS Final Recommendations Report, above n 756 at 6.
} 
New Zealand's history with multi-unit buildings is more recent so the country has not experienced the same level of problems like Scotland. Cross-lease properties started developing 60 years ago and fee simple townhouses only in the last 10 years or so. ${ }^{774}$

Where there are multiple people, there is not always commonality of interest. Therefore, for a community to function, they need a governance structure to provide direction.

There are four significant benefits of having a governance structure.

\section{Administrative leadership}

The first is that a governance structure provides the administrative leadership to manage a community. The administrative leadership benefit has two aspects.

The first is that it empowers a representative of the collective to look after the interests of the collective. Where there is common property, there has to be a way of administering that common property. Some small Body Corporates in Christchurch that did not have a Committee could not operate adequately. This illustrates that where everyone is charge, no one is in charge.

The second aspect of administrative leadership is that it enables decision-making through voting. The obvious conclusion from the Canterbury earthquakes is that unanimity is unworkable in a community. It is impossible to find a group of owners so homogenous that they will have a unanimous view on the matters affecting their homes. And this applies not only when it comes to repairs or maintenance of properties. It applies to day-to-day needs, like installing internet connection and fibre. In 2017, the government was forced to pass a law, Telecommunications (Property Access and Other Matters) Amendment Act, to introduce a simplified consenting process where there were multiple people with interest in a property. The trigger for that was that there were over 70,000 households that were

\footnotetext{
${ }^{774}$ Based on anecdotal evidence; I have been unable to find statistics on this point.
} 
unable to connect to fibre due to problems in obtaining consent to install it. ${ }^{775}$ This problem affected even unit titles, despite having a governance structure. But it proves the point that multiplicity of owners and decision-makers makes it difficult for outside parties to liaise with all owners, and that a representative is beneficial.

Owners are individuals living in a community but who have individual needs and interests. But these individual needs cannot be allowed to take precedence over the interests of the community.

This is acknowledged in the way the UTA envisages the management of Body Corporates. The UTA provides a democratic method of management through voting. That way, owners are free to express their opinions and vote in line with their interests, but are subject to the majority decision. Company share properties also have a system of making decisions through voting.

By contrast, cross-leases and fee simple townhouses involve many decision-makers, and sometimes they have a right of veto. The Canterbury experience was that veto powers, when exercised, can lead to deadlock situations and have a domino effect on the other owners. One owner's personal issues, interests, or even personal vendettas can create stalemate situations for the others in the development. This is neither fair nor desirable.

Unanimity does not work. And the larger the community, the more unwieldy the decisionmaking process becomes. Some cross-lease developments can be quite large, with one interviewee mentioning a 40-flat cross-lease development in Christchurch. ${ }^{776}$ In Auckland, the largest cross-lease development is a 65 -unit scheme. ${ }^{777}$ Fee simple townhouses can be large as well. ${ }^{778}$ It would be difficult if not impossible to achieve consensus between so many decision-makers when they have veto powers.

\footnotetext{
${ }^{775}$ New Zealand government "Telco property bill access passes third reading” Business Scoop (press release, 11 April 2017).

${ }^{776}$ Interview with RAS.

${ }^{777}$ Fredrickson, above $\mathrm{n} 1$ at 51.

${ }^{778}$ Erskine College development in Island Bay has 84 properties, including a significant number that are built with repair dependencies; Kenepuru Landing is proposing to build 700 properties, out of which a large number are fee simple townhouses.
} 
What needs to happen is for that veto power to become a voting power. Given that the owners are tied together by a repair dependency, the owners need a vehicle for decisionmaking. The two go hand in hand. There cannot be a repair dependency coupled with a decision independency. Owners need a governance structure to enable collective decisionmaking.

An added benefit is that a governance structure would take care not only of issues arising out of an accident or a natural disaster insurance claim, but also general repairs, maintenance, or preventative work as necessary. Cross-lease units built in 1960s would now be 60 years old. With age, they will require maintenance to the common elements. Without a governing body, the owners need to organise themselves to carry out this work. If one or more owners do not wish to engage with the process, this makes it difficult for the others to do the work and will lead to problems similar to those experienced in Scotland. Fee simple townhouses are newer but will inevitably require maintenance in the years ahead.

\section{A representative of the collective}

A second benefit of having a governance structure imposed by law is that the governing body becomes the representative of the collective and has the powers and responsibilities established by law, including the ability to enter into contracts and bind the other owners.

This representation element brings with it two special advantages.

The first advantage is that if an insured loss happens, the insurance company will only have to deal with the representative of the owners, rather than with multiple owners. This was of extreme benefit in Canterbury. ${ }^{779} \mathrm{EQC}$ and the private insurers struggled to liaise with multiple owners and this delayed resolution of the insurance claims. It was much easier for

\footnotetext{
${ }^{779}$ Interview with Young Hunter; Interview with RAS; Interview with Residential Risk Analysis.
} 
insurers to deal with Body Corporates because a representative of the owners liaised with the insurance company and construction professionals. ${ }^{780}$

Interestingly, three years into my research, when I interviewed EQC, EQC told me that they developed a special process for dealing with cross-lease remedial claims ${ }^{781}$ arising out of the Canterbury earthquakes. The remedial claims arose much later after the earthquakes and were not part of the Shared Property Project.

EQC said that it found it extremely difficult to liaise with multiple owners. When they encountered such situations, EQC would engage a "contract-communication facilitator"782 whose role was simply to receive and pass on communication from EQC, owners, banks, contractors, and so on - in effect creating a single point of communication. This role was separate from that of the project manager, whose role was to manage the construction. EQC would also engage a lawyer to set up a trust account for the particular development and ask all owners to pay their money into the trust account, to protect the collective and avoid situations where people would back out of the reinstatement project. The lawyer would also draft a memorandum of agreement setting out the owners' intention to undertake the repairs jointly and deposit their money into the trust account to fund the joint repair project. Owners would receive independent legal advice before signing these documents. All this was at EQC's cost. EQC applied this procedure for both cross-leases and fee simple townhouses that did not have a governance structure. ${ }^{783}$

What this illustrates is that EQC could not progress claims where there was multiplicity of contact points, bank accounts, and personal interests. EQC created an ad-hoc governance structure.

\footnotetext{
${ }^{780}$ Interview with Young Hunter; Interview with RAS; Interview with Residential Risk Analysis.

${ }^{781}$ EQC explained that "remedial claims" means Canterbury claims where the original reinstatement work was not up to standard and additional works were necessary to repair the properties.

782 Interview with EQC.

783 Interview with EQC.
} 
EQC's process came at a cost: there were fees required for the communicator, for the lawyer drafting the agreement and setting up the trust account, and for the lawyers giving independent legal advice to owners. No doubt, such a process took time and thus delayed the repairs.

EQC's process also required the owners' cooperation. EQC had no powers to force owners to be a part of this process. So, in the end it was reliant on the owners' voluntary cooperation. This highlights the need for the owners to have a common representative.

The second advantage of having a representative of the collective is that a governing body would have the power to enter into contracts on behalf of the collective. That is of a significant benefit especially where there is a large community. Without a legally recognised structure, there is no one visible to represent the owners. ${ }^{784}$ If the units are damaged and they need a whole-of-building repair, it would be difficult for an architect, an engineer, or a builder to enter into separate contracts with each individual owner. Instead, the governing body could act as a representative of the collective with authority to enter contracts. This would simplify matters for all involved. And this can work well even outside insurance claims, if there is just maintenance work or weathertightness defects that affect common property.

\section{A keeper of records}

The third benefit of having a governing body is that it would enable it to keep a register of owners, similar to a Body Corporate Committee. This would alleviate the problem of absentee owners, which was mentioned several times in relation to the Canterbury earthquakes. ${ }^{785}$

\footnotetext{
${ }^{784} \mathrm{Lu} \mathrm{Xu}$, above 731 at 243.

${ }^{785}$ Interview with Residential Risk Analysis; Interview with RAS; Toomey Finn research paper, above n 26 at 24 .
} 
The thesis recommends that the government adopts legislation that makes it compulsory for governing bodies of multi-unit buildings to keep a register of owners; and that those owners who are overseas must give the governing body the contact details of a representative based in New Zealand. There is a similar requirement for landlords who go overseas for more than 21 days; they must provide the tenant with the contact details of a representative based in New Zealand. ${ }^{786}$

Governance structure to apply the insurance money toward reinstatement

The fourth benefit of having a governance structure is in relation to the administration of insurance funds as they relate to the common elements of the building. This has two aspects.

The first is that a governing body would receive and use the insurance payout for the purpose of reinstating the property (assuming the payment was made in relation to common property). This will prevent situations where owners spend the insurance payout on other things and jeopardise the reinstatement process for the others. Owners using cash settlements for things other than repairs is of real concern ${ }^{787}$ and I consider this issue in more detail in the context of an examination of the advantages and disadvantages of cash settlements below. A governance structure will ensure that money is applied in accordance with the legislation, toward the repairs.

The second aspect is that having a governing body would enable the government to prioritise reinstatement over the mortgagee's interests, similar to the UTA provisions related to unit titles.

This thesis recommends that the government passes legislation that requires the governance body to apply the money toward reinstatement and prevent banks and other mortgagees

\footnotetext{
${ }^{786}$ Residential Tenancies Act 1986, s 16A.

${ }^{787}$ Cartwright, above n 278 at 207; Treasury, above n 454 in Appendix 1 at [1.1.5].
} 
from clawing back payments in satisfaction of the owners' debts. That will bring crossleases and fee simple townhouses in line with unit titles.

At the moment, for cross-lease properties and fee simple townhouses, mortgagees are entitled to require insurance money to be paid toward the mortgage if the property is destroyed or damaged. The choice sits with the mortgagee. ${ }^{788}$ That means that there is another layer of decision dependency. Removal of this layer will facilitate more efficient decision-making. On their side, the banks will not entirely be disadvantaged because the governance body will ensure the insurance payout is used for the reinstatement of the building, and therefore protect the value of their security. Without a governance structure to manage the money, it would not be practical to remove the banks' power of decision.

\section{Should a governance structure be imposed on existing titles?}

Imposing a governance structure where previously there was none could be seen as an infringement of the owners' freedom.

However, the reality is that most owners buy properties that come with terms already attached. The terms are pre-determined and non-negotiable. The only freedom the owners can exercise is whether or not to buy the property. Sometimes even the freedom to buy is constrained by financial circumstances (they might be the only properties a purchaser can afford).

Also, the owners' freedom is already limited. For cross-lease properties, there is already a form of governance body in the form of a Lessor. The Lessor is the group of owners combined. The group of owners have a number of rights in relation to each individual Lessee. For example, the group of owners can carry out the work for reinstatement of a Lessee's flat if the Lessee fails to do so, and invoice the Lessee for the cost. ${ }^{789}$ A crosslease title already comes with significant restrictions, and a form of governance structure.

\footnotetext{
${ }^{788}$ PLA 2007, Schedule 2, cl 3(1).

${ }^{789}$ ADLS Cross Lease, cls 23 and 19(b).
} 
The thesis proposes codifying some of the rights and obligations of cross-lease owners through legislation.

In relation to fee simple townhouses, some of them have a governance structure imposed by the property developers. ${ }^{790}$ In those situations, legislation should state that the existing arrangements remain in place but that the provisions of the legislation will supplement the good functioning of that particular multi-unit building community. For example, if there is a governance structure but this does not provide for common insurance, the legislation will force the governance body to arrange common insurance. If the governance body does not have the power to do so under the private arrangements, the legislation will override the private arrangements and give the governance body the powers and duties stated in the legislation. The thesis proposes that the legislation should override the private arrangements to the extent that it is necessary to ensure that the legal stipulations are met. The legislation will set out minimum standards, but owners can agree to additional rights and obligations if they wish.

The proposals will be impacting more significantly on fee simple townhouses with significant repair dependencies where there is no governance structure. Sale and purchase advertisements for fee simple townhouses often refer to a lack of a Body Corporate as something to be desired. There are two main reasons why the lack of a Body Corporate is attractive to purchasers: one is independence (owners like to decide for themselves what happens to their unit), and the other is the absence of Body Corporate fees. Indeed, Body Corporate fees have escalated significantly in recent years to the point where they are of concern. ${ }^{791}$

Both reasons are valid. It is more desirable for a homeowner to be able to make decisions on their own without the need to consult with the neighbours. And not having to pay fees

\footnotetext{
${ }^{790}$ See discussion in Chapter II, Part C3.

${ }^{791}$ Richard Deakin, CoreLogic "Rising Insurance pressure for Wellington apartment owners" CoreLogic (online ed, 9 October 2019); Rob Mitchell "Fears rising insurance and body corp costs could make apartment living unsustainable" Stuff (online ed, 4 May 2019); Kirst Wynn "Consumer Watch: Pitfalls for unit-buyers" Stuff (online ed, 2 June 2013).
} 
is again attractive. But the reality is that the owners' freedom is already restricted because of the repair dependencies. The governance structure simply recognises the de facto situation.

Changing contractual relations through legislation might seem like an interference, but there are precedents with the government doing it where this is for the better functioning of the community.

For instance, the government improved the functioning of company share schemes. In 1964 it introduced legislation to safeguard the legal effect of the licences to occupy. ${ }^{792}$ In 1965 , it clarified that the grant of a licence to occupy was not a return on capital so that owners would not be taxed. ${ }^{793}$ In 2007, it legislated a way of protecting the financial surplus of a company share scheme from being taxed. ${ }^{794}$ In 2017, it introduced significant provisions regulating the issue, registration, mortgage, surrender, and cancellation of licences.

The government also adopted legislative provisions which enabled a better working of cross-lease properties. ${ }^{795}$ These included provisions to clarify that a proprietor could create a lease to themselves ${ }^{796}$ and clarifying that granting a lease over a building existing or intended to exist on the land, was not a subdivision of land. ${ }^{797}$

Finally, the government adopted legislative provisions that indirectly facilitate fee simple subdivisions. In 2002, the Land Transfer (Computer Registers and Electronic Lodgement) Amendment Act introduced changes in relation to easements created or varied by easement instruments or on deposit of a plan. ${ }^{798}$ From that point on, it became possible for the same person to be the owner of both the servient and the dominant tenement, in other words to

\footnotetext{
${ }^{792}$ Law Commission, above at $\mathrm{n} 44$ at [2].

${ }^{793}$ Law Commission, above at $\mathrm{n} 44$ at [2].

${ }^{794}$ Section CD31(1).

${ }^{795}$ Mentioned in Thomas, above n 142 at 1137.

796 Property Law Amendment Act 1968, s 3.

${ }^{797}$ Section 350(4) Municipal Corporations Amendment Act 1971 inserted a deeming provision (s 35) in the Municipal Corporations Act 1954.

${ }^{798}$ For full discussion, see Brown, above n 68 at 1058.
} 
be both a grantor and a grantee. ${ }^{799}$ This assists with subdivisions ${ }^{800}$ and enables property developers to set easements while they still hold ownership of the development. The Land Transfer Act 2017 introduced covenants in gross. ${ }^{801}$ These covenants benefit a person or entity, rather than other land. They create a way for imposing obligations on property owners such as obligations to contribute to the upkeep of commonly owned infrastructure, or to oblige property owners to join residents' associations. ${ }^{802}$

These are examples where the government intervened to ensure the better functioning of properties that have been set up by private arrangements. But it did not stop there and there are other examples of government intervention in matters of private contract.

Relevant to the thesis, in 2006, the government adopted the Weathertight Homes Resolution Services Act 2006 (the WHT Act). Sections 22 and 23 of the WHT Act specifically override the provisions of Memoranda of Lease in cross-leases, or the constitution of a company share scheme in relation to majority votes. They provide a mechanism for bringing a claim in the Weathertightness Homes Tribunal and setting a process for making administrative decisions relating to representative claims. Some Memoranda of Lease require unanimity of decision between owners, but the WHT Act overrides this requirement and stipulates an 80 per cent majority. This enables a group of owners to bring a representative claim before the tribunal without having to achieve unanimity.

In 2017, the government adopted the Telecommunications (Property Access and Other Matters) Amendment Act to unable better access for installation of fibre technology to unit titles and company share properties. The Act recognised that, when more than one person's consent is required to access the property, there are difficulties in obtaining consent.

\footnotetext{
${ }^{799}$ Brown, above n 68 at 1058.

${ }^{800}$ Brown, above n 68 at 1058.

${ }^{801}$ Land Transfer Act 2017, ss 307A-F.

802 Minter Ellison (a law firm) "New land registration law coming" (online ed, 5 November 2018) <www.minterellison.co.nz>.
} 
These examples show that the government intervenes when it is necessary for the good functioning of multi-unit building communities. The Canterbury earthquakes demonstrate that there is a systemic problem with multi-unit buildings, and one of these problems is the lack of a governance structure. The thesis argues that there is a need for the government to intervene (again) to enable the better functioning of these properties.

This thesis is not the first to suggest significant changes to cross-lease ownership. The Law Commission, academics, and lawyers have written about the problems with cross-lease titles in the past, often recommending that this type of ownership be phased out and property owners forced to convert their title to another form of title. ${ }^{803}$ By comparison, the thesis suggests less invasive changes.

\section{Are there less intrusive alternatives to a compulsory governance structure?}

Nevertheless, I acknowledge that the proposal to impose a governance structure on existing cross-lease and fee simple townhouse developments is significant. I considered whether there are some alternatives which are less intrusive.

\section{A specialist tribunal}

One possibility could be creating a specialist tribunal to assist with resolution of disputes between owners of multi-unit buildings. This could be a free or low-cost tribunal where owners could go to resolve their differences. I believe a specialist tribunal could go a long way in resolving problems for multi-unit buildings. The Canterbury experience was that the human element was the main detractor in progressing claims, and often manifested itself through disagreements and civil disputes between owners. Having a specialist tribunal for resolving the differences will address some of these issues.

However, limiting the reform to a specialist tribunal would have a number of disadvantages. First, it would only capture the community at the end of a dispute. Resolving disputes quickly is good but avoiding disputes is better. Imposing a governance structure would avoid some of the disputes. Second, resolving disputes is not always fast. The

\footnotetext{
${ }^{803}$ Law Commission, above at n 44 at [6]; Pidgeon, above n 1; Toomey Finn research paper, above n 26 at 118.
} 
Canterbury experience was that disputes took time to process. The High Court created a special list for earthquake-related claims to give them priority and, despite that, they still took time to resolve. In that time, repairs could not be progressed, and insurance claims stalled. If there is a large-scale natural disaster, the specialist tribunal might become overwhelmed. Third, the existence of the Tribunal would not resolve other issues such as avoiding underinsurance or non-insurance and keeping a register of owners. There is little gain in a favourable tribunal decision ordering a joint reinstatement process if one owner is absent or cannot be located, or if they are not insured and have no financial means of contributing to a joint reinstatement process. An active governance structure would prevent such issues by keeping a register of owners and arranging common insurance.

\section{A dormant governance structure}

Another possibility could be to legislate for the creation of a governance body but without imposing an obligation to have an active Committee (to a small extent, similar to Body Corporates with nine or fewer units). The owners could choose to have an active Committee (and delegate their functions to the Committee) or could choose to resolve matters by having everyone involved when the need arises, subject to a majority vote. This would be less intrusive than an active governance structure and would provide the benefit of having a corporate entity to represent the owners. It would also enable decision-making through voting. So, it would address issues of multiple decision-makers and remove veto powers.

However, lack of active leadership can result in poor outcomes. The Canterbury experience was that those Body Corporates that did not have an active Committee were not acting as a community. Some owners were insured separately and made decisions independent of each other. Some owners had no insurance. There was no common purpose in looking after the property. The thesis argues that large cross-lease properties and fee simple townhouses with significant repair dependencies need active leadership. This alternative would still create a governance structure and remove the owners' rights of veto, so it would still face the same legal challenges as an active governance structure but with fewer benefits. 
An ad-hoc governance structure when the need arises

Lastly, another possibility is to create an ad-hoc governance structure if certain events happened. For example, the UTA could stipulate a procedure for making decisions in the event that a large cross-lease property or a fee simple townhouse development suffers damage or requires maintenance or preventative work to the common elements that require collaboration between owners. The UTA could also provide that, in those situations, a governance structure is created for the task of facilitating the reinstatement work; that the ad-hoc governance structure has a duty to apply any insurance funds toward reinstatement; and that banks could not direct the money to be paid toward repayment of mortgages. The UTA could provide a voting system based on a majority, and impose an obligation on homeowners to cooperate.

This alternative would have the advantage of providing leadership at the time this is needed. It would resolve issues of multiplicity of owners (because there would be a representative), veto powers, common decision-making, and managing the reinstatement funds.

The disadvantage is that such a governance structure would not have the opportunity to arrange common insurance for the units because it would only come into existence after a loss occurred. As such, there would still be a double decision dependency caused by the existence of multiple insurers. In addition, the governance structure would not have legal standing under the homeowners' individual policies (as the policies would be in the name of the owners rather than in the name of the governance body). If one owner is not insured or is underinsured, the others will be affected as well. There would be no control over insurance arrangements and ensuring there is adequate protection. The banks would not have certainty the money would be administered for the reinstatement of properties so they might demand that their rights to control the insurance payout remain.

I also note the recent change in the insurance companies' attitude toward multi-unit buildings without a Body Corporate structure. Owners of large cross-lease properties and 
fee simple townhouses might not be able to arrange insurance in the future unless they have an active governance body. ${ }^{804}$

There would be no register of owners, as the duties of the ad-hoc governance structure would be restricted to managing a certain event rather than day-to-day issues. It would still give rise to the same legal challenges arising out of restricting the owners' freedom. It would also have the disadvantage of imposing additional compliance and new procedures at a difficult time for the homeowners. For example, if a development suffers damage as a result of an earthquake, the owners would not only have to cope with the impact of the disaster on them personally, but also form a new structure and come to grips with a new process for making decisions. It would not be an easy task.

In conclusion, while there are some viable alternatives, the thesis posits that they only go part-way in resolving the problems. A compulsory governance structure would create the right expectations (that owners buy into a community); remove veto powers; solve the problem of underinsurance and non-insurance; address assignment and on-selling issues (because the policy is in the name of the community so the underlying ownership of the units becomes irrelevant); ${ }^{805}$ create a communication point with outside parties, including insurers and contractors; harness decision-dependency by reducing the number of people who need to be involved with external parties; provide a forum for making decisions about common property; address repair dependencies by insuring the property together; and act as a watchman over the insurance proceeds to ensure the money is applied toward reinstatement.

\section{Common and compulsory insurance}

The second property law reform is legislation requiring compulsory common insurance for large cross-lease properties and fee simple townhouses with significant repair dependencies.

\footnotetext{
${ }^{804}$ Interview with Chair of the ICNZ Personal Lines Committee.

${ }^{805}$ See discussion on this point in the "Common insurance" sub-chapter below.
} 
This reform should be adopted in tandem with the requirement for a governance structure.

\section{Common insurance}

Having compulsory common insurance has three benefits.

The first benefit is that it reduces the decision dependency. Insurers have powers of decision-making when it comes to investigating a loss and determining the method of reinstatement. It is not just the owners who have to arrive at an agreement, but insurers must also agree between themselves in relation to the reinstatement proposals. This creates a double decision dependency and delays reinstatement. In Christchurch, insurers were forced to adopt an unusual procedure to deal with situations where there were multiple insurers involved. ${ }^{806}$ What they did was to reduce the decision dependency by appointing a lead insurer to make decisions for all the other insurers. But it led to situations where an insurer made decisions for owners it had no contractual relationship with. ${ }^{807}$ This was a challenging legal situation for everyone involved.

The second benefit of having common and compulsory insurance is that it protects the interests of the group. Common insurance avoids the potential for one owner to leave their unit uninsured. As we have seen, in a multi-unit community, one owner's decision has an impact on the other owners. Common insurance recognises that a unit is part of a whole.

In the 1960s, when company share properties started to develop, there was a debate on whether the company should insure the building as a whole or whether the licensees should have the freedom to insure their properties as they saw fit. One author wrote at the time: ${ }^{808}$

Insurance is a crucial issue for all concerned with flat-owning companies, and it must be admitted that the law in this regard is deficient. One view is that the "ideal would be to allow every proprietor to insure his lot for any amount, or leave it uninsured, whichever he wished". With respect, this is imprudent. It would be as unwise for the company not to insure the whole building, as it would be unsafe to leave it up to each individual licensee. The latter is not the only one interested in his unit. It is part of a

\footnotetext{
806 Interview with Nine Dots.

${ }^{807}$ Interview with Nine Dots.

${ }^{808}$ Anthony P Molloy “Aspects of Flat-Owning Companies” [1969] NZLJ 44 at 45.
} 
whole, and will complement or detract from the whole according as it is maintained. If a licensee refused, or forgot, to insure, and his flat was gutted by fire, it would be a blot on the building as a whole. The value of the other flats would thereby fall, and, with no insurance moneys for rebuilding, would remain depressed.

So it is prudent for units which are part of a larger whole to be insured together.

The third benefit of having common insurance is that it resolves some of the insurance issues that arise where there is an assignment of claim. If there is common insurance organised by the governance body, the policy will be in the name of the governance body rather than in individual names. That means, if there is any change to the underlying ownership of the units, this will not affect the application of the policy.

It is also important to note that groups of owners insured together are likely to be offered an MD policy (rather than residential home policies), similar to Body Corporates. These will require regular valuations to support the Sum Insured, which means the owners would have professional help in setting the Sum Insured.

\section{Potential impediments in arranging common insurance}

Currently, the lack of a governance structure makes it unattractive for insurers to offer one policy to multiple owners. ${ }^{809}$ One interviewee said that insurers are refusing to insure crosslease units together. ${ }^{810}$

Indeed, insurers are concerned about having to liaise with multiple parties. ${ }^{811}$ The issue appears not to be one of unavailability of insurance but rather one of practicality. Who would have authority to arrange insurance on behalf of the group? Who would be responsible for paying the premium? Who would be making a claim and who would the insurer pay to discharge the policy obligations ${ }^{812}$

\footnotetext{
${ }^{809}$ Interview with Chair of the ICNZ Personal Lines Committee.

${ }^{810}$ Interview with specialised contractor with RAS.

${ }^{811}$ Interview with Chair of the ICNZ Personal Lines Committee.

${ }^{812}$ Interview with Chair of the ICNZ Personal Lines Committee.
} 
Insurers are already providing policies to unit titles. If the other types of multi-unit buildings had a governance structure, I do not imagine insurance companies would refuse to offer terms. In fact, the announcement from ICNZ in January 2021 suggests that as long as multi-unit buildings have a Body Corporate structure, insurance would be available. ${ }^{813}$

\section{Regarding compulsory insurance}

The thesis proposes that legislation be passed to make insurance compulsory for large cross-lease properties and fee simple townhouses with common foundations. This would bring these types of multi-unit buildings in line with unit titles.

Generally, Memoranda of Lease impose insurance obligations on owners, so adopting a law requiring compulsory insurance would simply codify the cross-lease owners' existing obligations. As for fee simple, as I have discussed above, there are some developments where compulsory insurance is already required.

What follows is that the requirement for compulsory insurance is likely to affect mostly fee simple townhouse owners who do not have contractual obligations to insure their properties.

The evidence from Canterbury is that residential properties were largely insured, and that non-insurance was minor. ${ }^{814}$ In New Zealand, in general, we have a high penetration rate of insurance. ${ }^{815}$ Most owners voluntarily insure their homes anyway. Fee simple townhouses have expanded mostly after the Canterbury earthquakes, which means they are usually newly built properties. Given the high cost of housing in New Zealand, I speculate that most are subject to a mortgage, which by implication means they have to be insured. ${ }^{816}$

\footnotetext{
${ }^{813}$ ICNZ “Caution”, above n 11.

814 Online survey insurance companies; Interview with Residential Risk Analysis; Interview with RAS; Interview with Residential Risk Analysis; Interview with Nine Dots.

815 Treasury New Zealand's Future Natural Disaster Scheme, above n 277 at 1.

${ }^{816}$ It is a bank requirement to insure the property when taking a mortgage. Also, Schedule 2 of the PLA 2007 implies a covenant to insure in all mortgage contracts.
} 
Imposing a requirement for compulsory insurance for multi-unit buildings is not going to be a significant departure from what is already happening in fact.

However, the thesis acknowledges that imposing compulsory insurance is a significant intervention. Is this justified?

In New Zealand, we have a few instances where the government legislated for compulsory insurance. Already mentioned, and the most relevant to the topic, is the UTA, which makes it compulsory for Body Corporates to have insurance for the building. The Act recognises the importance of protecting the interests of the collective.

Other types of compulsory insurance are $\mathrm{ACC}^{817}$ and EQCover (which is compulsory when purchasing house insurance). House insurance is de facto compulsory in most cases because banks require insurance when lending under a mortgage.

Outside the housing sector, there are a few instances where insurance is compulsory. For example, it is compulsory for international students to hold insurance until they complete their studies, ${ }^{818}$ and most working visa applicants are required to arrange medical and hospitalisation insurance. ${ }^{819}$ There are special compulsory insurance regimes for pollution damage by maritime vessels. ${ }^{820}$

Overseas, there are more. In the United Kingdom for example it is compulsory to have third-party vehicle insurance 821 and to pay social insurance (also called National Insurance). ${ }^{822}$ All employers must have employers' liability insurance ${ }^{823}$ and for certain professions their professional bodies make it compulsory to hold professional indemnity

\footnotetext{
817 Simon Connell "Community insurance versus compulsory insurance: competing paradigms of no-fault accident compensation in New Zealand" (2019) 3 Legal St 499.

${ }^{818}$ Immigration New Zealand <www.immigration.govt.nz>.

${ }^{819}$ Immigration New Zealand <www.immigration.govt.nz>.

${ }^{820}$ Bevan Marten Maritime Law in New Zealand (Thomson Reuters, eBook, ProQuest Ebook, 2016) at 186.

${ }^{821}$ Association of British Insurers "Motor Insurance" (online ed, undated) <www.abi.org.uk>.

822 National Insurance <www.gov.uk>.

${ }^{823}$ Employers' Liability insurance $<$ www.gov.uk $>$.
} 
insurance. ${ }^{824}$ International conventions such as the International Conventions on Civil Liability for Bunker Oil Pollution Damage and the Nairobi International Convention on the Removal of Wrecks establish compulsory maritime insurance requirements. ${ }^{825}$ In Australia, building guarantees (insurance) are compulsory in all states except Tasmania. ${ }^{826}$ Third-party vehicle insurance is compulsory, ${ }^{827}$ along with workers' compensation insurance and public liability insurance (for businesses). ${ }^{828}$ These are just a few examples.

In most if not all cases, it seems the reason for imposing compulsory insurance is to protect third parties, not the party taking the insurance (although this party benefits from the insurance in protection from liability or from a financial burden). The law recognises that, in certain situations, someone's actions can have a detrimental effect on others, and it is desirable to have a means of financial redress if that happens.

In community living, the decisions of a homeowner regarding insurance impinge on other homeowners. In Christchurch, interviewees referred to multiple situations where one uninsured or underinsured unit caused disruption and delay to the reinstatement of the other units. ${ }^{829}$ Therefore, in my view, there is a principled basis for making insurance compulsory for cross-lease properties and fee simple townhouses that share significant construction elements.

The same standard should apply to cross-leases and fee simple townhouses as to unit titles for which insurance is compulsory.

The condition for insurance is self-policed. The UTA does not provide for oversight of the Body Corporate's decisions. However, members of the Body Corporate Committees can

\footnotetext{
824 These professions include lawyers, accountants, architects and financial advisers. See Simply Business <www.simplybusiess.co.uk>.

${ }^{825}$ Marten, above n 820 at 198.

826 Tim Denne and Alexia Beer Guarantees and Insurance Products: Market and Policy Analysis (MBIE, online ed, 1 October 2018) <www.mbie.govt.nz> at 21.

827 Insurance Council of Australia "Motor vehicle insurance" (online ed, undated) <www.insurancecouncil.com.au>.

${ }^{828}$ Business Insurance <www.business.gov.au>.

${ }^{829}$ Interview with EQC; Online survey insurance companies; Interview with Residential Risks Analysis; Interview with RAS; Interview with Homeowner 2.
} 
be personally liable for breaches of the UTA and of the Body Corporate rules. ${ }^{830}$ The thesis suggests that, for consistency, the same standard should apply to other types of multi-unit buildings.

How is this to be achieved?

Given that the requirement for common and compulsory insurance is to be implemented together with the proposal for a governance structure, the thesis suggests that the obligation to insure is set out in the UTA, under the same section dedicated to cross-lease properties and fee simple townhouses. The UTA should mirror the provisions related to unit titles.

\section{Administrative Rules}

The third reform for a better administration of multi-unit buildings is to impose rules that set out the rights and obligations of owners, delineate a process for maintenance and repair, and support resolution of disputes. This proposal applies to large cross-lease properties and fee simple townhouses with any type of dependency (minor or significant).

As mentioned earlier in the chapter, this proposal is not intended to apply to unit titles and company share schemes. Unit titles have a code of conduct and management rules set out in the UTA. Company share schemes also have a code of conduct and management rules set out in their constitution, further supported by legislative provisions, including the Land Transfer Act 2017. Buildings with no repair dependencies do not require close collaboration between owners in relation to reinstatement. That leaves cross-lease titles and fee simple townhouses with repair dependencies.

\section{What will the Administrative Rules provide?}

The thesis proposes that the Administrative Rules address three specific aspects. The first is to imply minimum standards in private easements. The second is to legislate a process

${ }^{830}$ Guardian Retail Holdings v Buddle Findlay [2013] NZHC 1582, [2013] NZAR 988. 
for reinstating properties in close proximity to each other. And the third is to facilitate dispute resolution between members of a multi-unit community.

Implied covenants in easements

The thesis proposes that legislation be passed to imply covenants in existing easements applying to multi-unit buildings. The legislation should create minimum standards implied in every easement, but owners should be able to adopt additional covenants over and above the minimum required.

The implied covenants should define the property they apply to, should clarify the rights and obligations of owners, including the obligation relating to the shared cost of maintenance and repair, and provide a mechanism for dispute resolution.

In New Zealand, there is legislation implying covenants in grants of vehicular rights of way $^{831}$ and in easements for rights to convey or drain water, and rights to convey telecommunications, electricity, and gas. ${ }^{832}$ But there is no such legislation implying covenants in easements related to party walls or other shared construction elements. The rights conveyed to fee simple townhouse owners depend on lawyers drafting adequate provisions. If something is omitted or intentionally excluded, there is no legislation to fall back on. With the expansion of medium and high-density housing, I believe it would be prudent to imply minimum terms through legislation.

A question arises in relation to situations where there are no easements where there should be easements. RAS mentioned one case in Canterbury where fee simple townhouses with shared foundations and party walls had no easements registered on the title. ${ }^{833} \mathrm{I}$ believe more research is required to determine how widespread such situations are before deciding on a course of action. If they are rare, one way to deal with the situation would be to adopt a provision that would give an affected party access to a dispute resolution mechanism

\footnotetext{
${ }^{831}$ PLA 2007, s 297 and associated provisions including PLA 2007, Schedule 5.

${ }^{832}$ Land Transfer Regulations 2018, s 21 and associated provisions, including Land Transfer Regulations 2018, Schedule 5.

${ }^{833}$ Interview with specialised contractor with RAS.
} 
similar to the mechanisms available to those who have an easement. If the research reveals a widespread issue, the government should consider adopting implied terms where these have been completely omitted.

Setting a process for repairs to buildings that share construction elements

The second recommendation is for the government to pass a law that sets out a predetermined process for repairing buildings that share construction elements. This should include a definition of the buildings captured by the legislation; requirements for notification of the adjacent owners affected including an obligation to state the works proposed, likely duration of the work, and an assessment of whether the work will affect the adjacent buildings and how the damage is going to be reinstated; any cost sharing where this is required; and provision for dispute resolution.

In the United Kingdom there is a large number of multi-unit buildings. About 75 per cent of the housing stock consists of semi-detached dwellings and flats. ${ }^{834}$ In 1996, the United Kingdom adopted the Party Wall etc Act, which makes provision in respect of party walls, excavation and construction in proximity to certain buildings or structures, and for connected purposes.

The Act stipulates extensive rights for property owners in relation to their properties and shared construction elements. For example, owners have the right to underpin, thicken, or raise a party structure, a party fence wall, or an external wall that belongs to the building owner and is built against a party structure or party fence wall; ${ }^{835}$ make good, repair, or demolish and rebuild, a party structure or party fence wall in a case where such work is necessary on account of defect or want of repair of the structure or wall; ${ }^{836}$ demolish a partition that separates buildings belonging to different owners but does not conform with statutory requirements and build instead a party wall that does conform; ${ }^{837}$ cut into a party

\footnotetext{
${ }^{834}$ Statista "Distribution of population in the United Kingdom (UK) as of 2018, by dwelling type" (online ed) <www.statista.com>.

835 Section 2(2)(a).

${ }^{836}$ Section 2(2)(b).

${ }^{837}$ Section 2(2)(c).
} 
structure for any purpose (which may be or include the purpose of inserting a damp-proof course). ${ }^{838}$

A building owner proposing to start work covered by the Act must give adjoining owners notice of their intention in the way set down in the Act. The Act stipulates what the notice must contain, including the form, contents, timeframes, and service. ${ }^{839}$ Adjoining owners can agree or disagree with what is proposed. Where they disagree, the Act provides a mechanism for resolving disputes. If the parties agree, they can appoint an agreed surveyor who will make a determination. ${ }^{840}$ If they disagree on the appointment of a surveyor, each party can engage their own surveyor, who will then engage a third surveyor. ${ }^{841}$ If a party refuses to engage a surveyor or neglects to appoint a surveyor within ten days from the day a notice is served on them, the other party may appoint a surveyor for the other side. ${ }^{842}$ The agreed surveyor, or the three surveyors, or either of the two surveyors have the power to make an award. ${ }^{843}$ The award may determine the right to execute any work; the time and manner of executing the work; and any other issues incidental to the dispute. ${ }^{844}$ The surveyors also determine who will pay the cost of obtaining the surveyor's award. ${ }^{845}$ The award is conclusive and cannot be challenged in any court, except for a right of appeal to the county court within 14 days of the date of the award being served on them. ${ }^{846}$

The adjoining owner must allow the neighbour access for the purpose of the work unless there is some other reasonable way of accessing the site, subject to a 14-day notice. ${ }^{847}$ The Act makes it an offence to refuse to permit a person to do anything they are entitled to do

\footnotetext{
${ }^{838}$ Section 2(2)(f).

${ }^{839}$ Section 3.

${ }^{840}$ Section 10(1)(a).

${ }^{841}$ Section 10(1)(b).

${ }^{842}$ Section 10(4).

${ }^{843}$ Section 10(11).

${ }^{844}$ Section 10(12).

${ }^{845}$ Section 10(13).

${ }^{846}$ Sections 10(16) and (17).

${ }^{847}$ Section 8.
} 
under the Act. ${ }^{848}$ The person doing the work must not cause unnecessary inconvenience to the neighbour, and must compensate the neighbour for any loss or damage. ${ }^{849}$

Having a process set out in advance means homeowners know what to expect, and there is a procedure to follow. Given that New Zealand is moving toward housing intensification, it would be wise to anticipate the sort of problems that could arise between people living in close proximity. The thesis proposes pre-empting problems and legislating a process for repair procedures. As I mentioned already, houses are expensive in New Zealand and owners need to be able to reinstate without the risk of a legal dispute with their neighbour. Having the process mapped out by legislation will set the expectations and guide owners and their advisers throughout the process.

In New Zealand we have something somewhat similar applying to boundary fences. The Fencing Act 1978 sets out a procedure for erecting, maintaining and demolishing boundary fences. The Act stipulates a procedure for giving notice of work, ${ }^{850}$ how the cost will be shared, ${ }^{851}$ the timeframe for doing the work, ${ }^{852}$ and a process for resolving disagreements. ${ }^{853}$ The Act seems to acknowledge that where property is shared, owners need guidance on how to build it and maintain it.

The Party Wall etc Act 1996 could serve as a prototype for a New Zealand Act, but one that will need adapting to New Zealand conditions. One aspect to be considered carefully, for example, is the availability of surveyors or engineers and whether these professionals would be available at such short notice.

\section{Dispute resolution mechanisms}

The third recommendation is to create accessible dispute resolution systems for members of multi-unit building communities.

\footnotetext{
848 Section 16.

${ }^{849}$ Sections 7(1) and (2).

${ }^{850}$ Section 10.

${ }^{851}$ Section 9.

852 Section 14.

${ }^{853}$ Sections 21 and 24.
} 
This thesis proposes that the government legislates to allow owners of cross-lease property and fee simple townhouses to follow the same dispute resolution process set out for unit titles. All multi-unit buildings should be aligned in this respect.

At the same time, there should be a review of the fees to access the disputes resolution system.

The UTA has a three-tiered dispute resolution system. The first tier (in the Tenancy Tribunal) costs $\$ 850$ including GST for a Category 2 dispute and $\$ 3,300$ including GST for a Category 1 dispute. The cost increases if a dispute goes to the District Court or to the High Court (tier two and three). There has been criticism of the $\$ 850$ filing fee in the Tenancy Tribunal. ${ }^{854}$ One interviewee suggested that access to the dispute resolution system was expensive and that it should be free. ${ }^{855}$

Canada has much lower fees for dispute resolution, and the system appears to be working well. In Ontario, more than 1.6 million people live in a condominium, ${ }^{856}$ which are the equivalent of our Body Corporates. In 2015, the Condominium Act, 1998 changed to allow for the creation of a Condominium Authority of Ontario (CAO), which is an independent, not-for-profit administrative authority under the Condominium Act, and accountable to the government. CAO has two main roles: consumer protection and dispute resolution. The latter is achieved through the Condominium Authority Tribunal (CAT), which is a fully integrated online tribunal. Like in New Zealand, the fees to access a dispute resolution system are in three tiers, but in contrast, much lower. The lowest fee is $\$ 25$ for a negotiation, ${ }^{857} \$ 50$ for mediation, and $\$ 125$ for a Tribunal Decision Adjudication. ${ }^{858}$ Before accessing the dispute resolution mechanism, the parties are guided through a number of pre-conflict guidance steps, which answer most common issues. CAO found a dramatic

\footnotetext{
${ }^{854}$ Interview with Greenwood Roche; John Hogan "Unit Titles in the Tenancy Tribunal" in Unit Titles Density and Intensity (NZLS seminar, 2015) at 68.

${ }^{855}$ Interview with Greenwood Roche.

856 Robin Dafoe, CEO of the Condominium Authority of Ontario "Apartment/Condo Regulation, Management and Future Trends - International Perspective" (webinar, 15 December 2020) at 3.

${ }^{857}$ This is self-directed, and parties are encouraged to resolve the dispute between themselves without the need for a CAT member's intervention.

${ }^{858}$ Dafoe, above $\mathrm{n} 856$ at 10.
} 
reduction in the numbers of people who accessed the pre-conflict guidance step $1(21,000$ page views) to the number of disputes that went all the way to Adjudication (78 disputes). ${ }^{859} \mathrm{CAO}$ believes that early intervention, education, and guidance help resolve most disputes. The Canadian system is certainly one that can provide guidance to $\mathrm{New}$ Zealand.

For cross-lease properties, the Memoranda of Lease invariably specifies that disputes would be resolved through arbitration. ${ }^{860}$ Arbitration is a foreign concept for most homeowners, and likely for most lawyers. It works by parties first agreeing on an arbitrator. This could be a professional arbitrator or a lawyer or a retired judge with experience in this area. The claimant then must prepare and submit a Points of Claim and the respondent has to file a Response. Discovery and inspection of documents would follow, and then a hearing, which may or may not involve examination and cross-examination of witnesses. The arbitrator will make a decision, known as an award.

As seen in Chapter IV, many interviewees referred to ongoing disputes involving crosslease properties. RAS for example advised hundreds of cross-lease property owners. Many had disputes with their neighbours and could not get traction with their claims. In May 2019, about nine years after the first earthquake, when I interviewed RAS, they had not yet had a dispute go to arbitration. When asked, RAS explained that "[you] can't do an arbitration, no one can afford [it]". 861

Arbitration is expensive. For example, the New Zealand Dispute Resolution Centre's fees $^{862}$ include a registration fee of $\$ 1,000$, an administration fee between $\$ 1,250$ and $\$ 30,000$ (depending on the value of the dispute), and then the arbitrator's fees and expenses. These are two types: fixed fees (for disputes up to $\$ 50,000$ ) or general fees for disputes above $\$ 50,000$. Fixed fees are between $\$ 3,000$ to $\$ 10,000$. General arbitration fees are between $\$ 30,000$ to $\$ 300,000$. For a homeowner dispute related to repairs of say

\footnotetext{
${ }^{859}$ Dafoe, above n 856 at 11.

${ }^{860}$ Pidgeon and Tappenden, above n 88 at 1216.

${ }^{861}$ Interview with specialised contractor with RAS.

${ }^{862}$ Fees taken from New Zealand Dispute Resolution Centre's website <www.nzdrc.co.nz> (2021).
} 
$\$ 250,000$, the arbitration fees could be around $\$ 37,500$. These do not include the cost of having a lawyer to present the case at arbitration.

In addition to cost, arbitration has the downside of being an adversary system similar to litigation. An adversary process damages relationships, which is not ideal for parties who are going to live in proximity with each other going forward. RAS thought that with arbitration "you just damage all the people in the process while you are trying to work your way through it". 863

In my view, given the increasing number of multi-unit buildings, it might be an opportune time for the government to consider a specialist tribunal (similar to the Canadian system) or upskilling the Tenancy Tribunal to hear disputes between multi-unit building owners as well.

The government is currently reviewing the UTA. Among some of the issues it is considering is access to dispute resolution. ${ }^{864}$ This is a timely review and I endorse the efforts to create a better way for unit owners to resolve their disputes.

\section{How is this proposal to be achieved?}

The thesis proposes that the Administrative Rules for multi-unit buildings are mandated through legislation. This has three benefits. The first is publicity. Legislation acts as a loudspeaker affirming the rights and obligations applicable to multi-unit buildings. This helps owners understand that they are buying into a multi-unit building and that, in certain situations, decisions need to be made together. The second is clarity. Most Memoranda of Lease use archaic language that is difficult to understand. By contrast, a new piece of legislation will use modern language and plain English. The third benefit is accessibility. If the law is clear, rights will be easier to enforce.

In relation to the three distinct issues to be addressed, the government could consider addressing them into one Act, or a series of amendments to existing legislation. For

\footnotetext{
${ }^{863}$ Interview with RAS.

${ }^{864}$ O’Neill, above n 241 at 4.
} 
example, the implied terms for easements and the procedure for repairing adjoining properties could be stipulated in the PLA 2007, while the dispute resolution mechanisms could be stipulated in the UTA, alongside the new provisions related to a governance structure and compulsory common insurance. There might be an overlap in provisions related to dispute resolution, so all amendments should be consistent with each other.

Addressing the property law issues will create stronger communities. Cross-leases and fee simple townhouses will benefit from administrative leadership, and have a pre-determined way of making decisions through voting in relation to matters that affect common property (if and when the need arises). Common and compulsory insurance will safeguard against the danger of underinsurance and non-insurance. Owners' rights will be supplemented by implied terms in easements that will create more secure and enforceable rights. If there is a need to carry out maintenance or repair work to common structural elements, an Act will stipulate a procedure for dealing with the adjoining owner. This will create certainty and avoid costly legal disputes. An efficient dispute-resolution system will ensure that owners have their opinions heard and rights protected. This is essential in any community.

\section{Some recommendations specific to cross-lease titles}

It is clear from the research that cross-leases are complex titles. This has been extensively highlighted in past research and academic writing. ${ }^{865}$

In 1999, the Law Commission surmised that this type of title is "ineradicably flawed" and needs to be abolished. ${ }^{866}$ The Law Commissioner at the time called cross-leases "timebombs waiting to explode" 867 and recommended "a positive programme of conversion, either to subdivision or to a unit title scheme". 868

\footnotetext{
${ }^{865}$ Pidgeon, above n 1; Toomey Finn research paper, above n 26 at 118.

${ }^{866}$ Law Commission, above at $\mathrm{n} 44$ at [6].

${ }^{867}$ DF Dugdale "Shared Ownership of Land" [1999] NZLJ 29 at 29.

${ }^{868}$ Law Commission, above at n 44 at [14].
} 
The Toomey Finn research paper also recommended that cross-leases be abolished. ${ }^{869}$

Despite wide academic and legal support for the past 25 years, the government did not adopt these proposals. It is unclear why. Perhaps implementing the conversion would be difficult. Indeed, conversion raises a few questions. Would the government impose restrictions on what type of title a cross-lease could be converted to? Would there be a cut off in terms of size? What if there is a 40-flat cross-lease development? Would such a large development be able to convert to fee simple? And if not restricted, who will be tasked with the responsibility of setting out the easements applicable to the shared elements? Will the government impose pre-set easements? And for fee simple, how are the homeowners going to deal with insurance?

\section{Conversion to unit title}

A conversion to unit title would resolve the insurance issues identified by the thesis because most of the time owners would be unified under a governance structure and would have common insurance. ${ }^{870}$ There would be a representative of the owners to liaise with the insurance company. There would be only one insurance policy, rather than multiple insurers on site. Owners could make decisions through voting.

Had the proposal to convert cross-leases to unit title been implemented, we would not have had the problems we had with cross-lease properties in Canterbury. There would have been fewer problems, similar to what was experienced by Body Corporates.

However, as I mentioned, this proposal had not been adopted, and the issue might be one of cost. To convert a cross-lease to a unit title, would involve some cost (for example there would be legal fees to reissue the titles).

This thesis takes a different approach to the problem. It does not suggest a forced conversion of cross-leases to unit titles and instead it suggests a hybrid model where developments with more than five units which share construction elements remain under a cross-lease title, but subject to new legislative provisions that make then akin to unit titles.

\footnotetext{
869 Toomey Finn research paper, above n 26 at 118.

${ }^{870}$ For small Body Corporates having a Committee is optional; and if the units are standalone owners can decide to have separate insurance. See discussion in Chapter II Part F6.
} 
These provisions include imposition of a compulsory governance structure; making decisions through voting; keeping a register of owners, arranging common insurance and applying the insurance money toward reinstatement.

This proposal has the advantage of providing a management system for the community of owners similar to unit titles without incurring the price of a conversion.

\section{Conversion of standalone cross-leases to fee simple title}

Conversion to fee-simple would benefit standalone cross-lease properties, the so-called title-driven multi-unit buildings. Since there is no repair dependency, changing the crosslease title to fee simple would also remove the decision dependency. The property owner would be free to make their own decisions in relation to reinstating their property without possible holdbacks from the group of neighbours.

Unfortunately, a conversion would be expensive because it would require engaging a property surveyor to prepare plans, an application to the Council, and a lawyer to register the new title. The subdivision would be subject to the requirements of the Resource Management Act 1991 and of the local Council rules. Many cross-lease titles have common services (water, sewerage, and so on). As part of a subdivision, these services would need to be separated and new services laid. The cost to achieve a conversion could be thousands of dollars. The larger the development, the more work required.

There have been attempts to minimise compliance costs in a conversion. In 2018, a claimant applied to the Environment Court for a declaration that converting cross-lease properties to fee simple titles does not constitute a subdivision of land. The intention was to avoid having to apply for a resource consent, and therefore save costs. The Environment Court refused to make such a declaration. ${ }^{871}$ The attempt to get judicial relief and simplify the conversion process failed.

${ }^{871}$ Re McKay [2018] NZEnvC 180. 
The thesis proposes that the government consider passing special provisions to relax the rules applicable to the conversion of cross-lease properties. To the extent that the government can, it should legislate to make it easier for standalone cross-lease properties to be converted to fee simple.

\section{Conversion of cross-leases that share construction elements to fee simple titles}

The thesis does not support the past proposals to convert cross-leases to fee simple titles unless the units are standalone. The reasons for taking a different view are as follows.

First, a change of title would not address the real problem - which is the repair dependency. Units that share construction elements give rise to decision dependency. The reality is that, for these properties, conversion would simply mean moving from one type of multi-unit title to another type of multi-unit title. So, it would be of little or no benefit.

Second, both cross-leases and fee simple titles are premised on maximising owner autonomy. So, owners will continue to have problems, each owner wanting to make decisions independent of each other. The desire to act independently is likely to increase with the move to a fee simple title, so a conversion might create more problems.

Third, conversion to fee simple would not resolve the insurance issues, as fee simple owners are likely to want to insure their units separately. So, there would still be multiple insurers and multiple decision-makers on site. The Canterbury experience showed that having multiple decision-makers and multiple insurers does not work in a community.

Fourth, while the Memorandum of Lease creates an obligation to insure the unit, there is no inherent obligation to insure a fee simple townhouse. Unless such an obligation is expressly provided for in the new fee simple title, owners would be at liberty of choosing whether to insure their property or not. The Canterbury experience was that non-insurance and underinsurance had a domino effect on the other members of the community. So there is an increased risk that owners would not insure if there is no positive obligation. 
Fifth, the Memorandum of Lease stipulates maintenance and repair obligations for the Lessees. Under a fee simple title, unless an obligation to repair or maintain the property is stipulated by way of easements and covenants, there are no intrinsic obligations to keep the property in good repair. So, converting a cross-lease to a fee simple title creates additional problems.

The potential for something to go wrong is increased with a fee simple ownership structure. The titles for fee simple townhouses are dependent on individual conveyancing lawyers grafting the relevant rights and obligations on the title. If they omit anything, there is no legislation to fall back on, and it will lead to disputes.

Cross-leases and fee simple ownership structures used for townhouses share certain similarities in that they focus on owner independence and decision-making, veto powers, lack of a governance structure and separate insurance. I anticipate that going forward, fee simple townhouses will create problems similar to those experienced by cross-lease owners in the past, if left unaddressed.

As far as fee simple townhouses are concerned, the thesis proposes that going forward the fee simple townhouses are either built with no repair dependencies, or if they are built with repair dependencies, they should be under a unit title structure. As for the existing stock, the government should legislate imposing a governance structure and common insurance (similar to what is proposed for cross-leases), to bring them more in line with unit titles. This would recognise them for what they are: communities of owners linked together by repair dependencies, and who need to make decisions together in certain circumstances.

\section{Repair Dependency Calculator}

Before I move on to discuss the changes suggested to the insurance claims process, I want to provide more details on the repair dependency calculator.

Three factors emerge as the most important in calculating a building's repair dependency. The first is the title itself. The title brings with it certain rights and obligations, and it determines the way the decision dependency is demonstrated in practice. The second factor 
is the repair dependency. Multi-unit buildings have shared building elements. However, they are not equal in importance. The Canterbury earthquakes experience was that, when buildings have shared foundations, this creates a significant repair dependency. The calculator gives the foundations more weight. The final and third factor is the governance structure. Even buildings with significant repair dependencies can be managed well if they have a suitable and active governance structure.

Based on these three pillars I have created an algorithm to help calculate a property's repair dependency level. This has translated into an online calculator that allows a property owner or a prospective property owner to calculate the repair dependency score of the property they are interested in. The values extend from 0 to 100 points, with zero meaning no repair dependency and 100 being maximum repair dependency.

The questions flowchart and the table of values is set out in Appendix A.

I have also uploaded the calculator onto a website for actual use. ${ }^{872}$

\section{B Insurance Industry Measures}

Coming back to proposals for reforms, in addition to the property law measures, the thesis proposes changes to the way insurance companies manage claims for multi-unit buildings.

The thesis proposes five reforms. The first relates to cash settlements and proposes they should be approached with circumspection. The second reform aims to address underinsurance. The third focuses on reducing the layers of decision dependencies by avoiding dual handling of claims. The fourth measure suggests an improved process for data collection on policies for multi-unit buildings. Lastly, again something aimed at addressing the decision dependencies, insurance companies should prioritise claims so they can be resolved during the so-called Honeymoon Period.

${ }^{872}$ The address of the website is https://publicfamily101.wixsite.com/repairdependencycal. 


\section{Careful use of cash settlements}

The thesis argues that, while cash settlements are a legitimate way of discharging a policy, for multi-unit buildings they present some problems. Because of the repair dependencies, owners rely on each other to apply the insurance proceeds toward reinstatement. The thesis warns about the dangers of cash settlements and makes recommendations about the process of discharging claims by a payment of money.

In Canterbury, insurers focused on getting involved with the repair process. There appears to have been a political expectation that insurance companies will assist with managing repairs. ${ }^{873}$ One insurer recounted that "cash settlement was a dirty word". ${ }^{874}$

EQC also managed repairs. EQC's stance was dictated by the government. ${ }^{875}$ In its 20102011 annual report, EQC explained that there was a risk that tens of thousands of Canterbury owners, each with a cheque in hand trying to find a builder, would lead to repair cost inflation and unpredictable quality of repairs. ${ }^{876}$

Most insurance companies engaged project management companies, ${ }^{877}$ which in turn engaged professionals for the different aspects of the work: to identify the damage, scope the repair, prepare the drawings, obtain building consent, undertake the repair, or rebuild. The construction contract was usually between the homeowner and the builder, with a provision for payments scheduled from the insurance company. 878

\footnotetext{
${ }^{873}$ Interview with Vero Insurance.

${ }^{874}$ Interview with Vero Insurance.

${ }^{875}$ Cartwright, above n 278 at 135.

${ }^{876}$ EQC Annual Report 2010-2011.

${ }^{877}$ For example, EQC used Fletcher Earthquake Recovery; IAG New Zealand used Hawkins Management; Southern Response used Arrow International.

${ }^{878}$ Robin v IAG New Zealand, above n 483 at [3]; E\&E v IAG New Zealand [2019] CEIT 0013 at [5]; Heale $v$ IAG New Zealand [2019] NZHC 2829 at [5].
} 
However, multi-unit buildings were problematic. The human element coupled with the technical issues made things difficult. Around 2014-2015, insurers started cash-settling claims: ${ }^{879}$

One of the interviewees, who at the time of the Canterbury earthquakes was involved with handling claims for an insurance company, gave an insight into one of the reasons insurers moved to cash settlements: ${ }^{880}$

The claims handlers and consequently myself were dealing with complaints [and people] would accuse and abuse us of the most awful things. It was terrible. And you get to a point where you think you've just got to cash settle and move this one on because there are other people waiting in the queue that you need to deal with.

An insurer confirmed there was a mindset change: 881

When the Shared Property Project started in Canterbury, it was this overarching, almost instruction from the Prime Minister and Gerry Brownlee that the people living in shared property were vulnerable, and that we needed to look after them. They were [a] lower social-economic group, and we must assist them with our rebuild programme.

$\cdots$

And then you had all the problems with the underinsured, the uninsured, the assigned, the rat bags, the neighbours that hated each other. Over the years, it became clear that there was nothing in the policy to force the insurer to go through so much pain to resolve a claim. So, there has been a mindset change, a complete turnaround. Everybody's first option [is to] cash settle.

In addition, where insurers are involved in the repair process, they can be held responsible for building defects. ${ }^{882}$

\footnotetext{
${ }^{879}$ Tibshraeny, above $\mathrm{n} 643$.

${ }^{880}$ Interview with Residential Risk Analysis.

${ }^{881}$ Interview with Vero Insurance.

${ }^{882}$ Sleight $v$ Beckia Holdings, above n 483; Bruce \& ors v IAG New Zealand, above $\mathrm{n} 483$; The University of Newcastle v GIO General Ltd (1995) 8 ANZ Insurance Cases 61-281 (NSWSC). For an academic discussion on the topic, see Robert Merkin and Chris Nicholl (eds) Colinvaux's Law of Insurance in New Zealand (Thompson Reuters, Wellington, 2014) at 543-544.
} 
Unfortunately, there were houses in Canterbury that had not been repaired properly. These have come to be known as botched repairs. ${ }^{883}$ In 2015, MBIE surveyed 100 properties that had earthquake repairs. The survey found that "32 of the 90 homes that met the survey criteria had structural repair work carried out that was non-compliant with the Building Code" ${ }^{884}$ An additional 23 homes had minor repair defects. The botched repairs crisis that followed the Canterbury earthquakes received wide media $\operatorname{cover}^{885}$ and resulted in a number of litigated cases. ${ }^{886}$ EQC formally acknowledged the problem and offered to address the defective repairs. ${ }^{887}$

Embroilment in litigation and being liable for another round of repair costs resulted in insurance companies being reluctant or unwilling to be involved with the reinstatement process in subsequent events. When the Kaikōura earthquake happened, the insurers took quite the opposite position and moved almost exclusively to cash settlements. ${ }^{888}$ Under the agency agreement, EQC expected the private insurers to cash settle all claims on behalf of EQC. ${ }^{889}$

There are clear advantages to an insurer using a cash settlement mechanism to resolve a claim. First, it is quick. Claims can be resolved much faster with a cash payment. In a large event, this can be quite beneficial to an insurance company. It reduces the amount of work

\footnotetext{
${ }^{883}$ Cartwright, above n 278 at 144.

${ }^{884}$ MBIE "Earthquake Repairs to Canterbury Homes - Home Inspection Survey Report" (online ed, August 2015) <www.mbie.govt.nz/assets/9993cf73bd/home-inspection-survey-report.pdf> at 3.

885 "Hundreds of people buy faulty homes as EQC confirms potential billion-dollar hole" The New Zealand Herald (online ed, 17 April 2018); "Homeowners left in limbo after faulty EQC repairs" Radio New Zealand (1 March 2018); Michael Hayward "Government to pay for failed repairs to earthquake-hit Canterbury homes" Stuff (online ed, 15 August 2019).

886 Robin $v$ IAG New Zealand, above $\mathrm{n}$ 483; E\&E $v$ IAG New Zealand, above $\mathrm{n}$ 878; Weir v IAG New Zealand [2019] NZHC 3282; Heale v IAG New Zealand, above n 878; Dewes \& ors v IAG New Zealand \& ors, above n 483; Self-Realization Meditation and Healing Centre v IAG New Zealand \& ors, above n 483; Evans v IAG New Zealand, above n 483.

${ }^{887}$ EQC "Getting your claims reviewed" < www.eqc.govt.nz>; Interview with EQC.

${ }^{888}$ Interview with ICNZ (Emma Gabor, Wellington, 15 November 2017); Written interview questions (Q \& A style) with IAG New Zealand; Cartwright, above n 278 at 207.

${ }^{889}$ Memorandum of Understanding Relating to Kaikōura Earthquake Claims Management (obtained under Official Information Act 1982 request to EQC), cl 2.1.
} 
it has to do on a claim and the number of staff it needs, and it prevents reputational damage to its brand. Being able to settle claims faster will always make the insurer look better.

Second, a cash payment might remove potential liability for faulty repairs, although the recent decision of Sleight $v$ Beckia $^{890}$ suggests that any insurer involvement in the reinstatement process could create a risk of liability for defective repairs. However, a cash settlement will make easier for the insurer to close the file and walk away.

Third, with a multi-unit building claim, the insurer would avoid getting involved with the human aspect and neighbouring disputes highlighted in Chapter IV above.

Following the Kaikoura earthquake, ICNZ noted several advantages of a cash settlement approach: 891

[Cash] settlements can be adjusted if missed damage is found or costs are inaccurate; claimants are provided with a fully documented account of what is required of the builder; and settlements can be concluded faster than a managed repair, which is advantageous to the insurer (who can settle much more quickly). Cash settlements are also reassuring for the reinsurance industry. In addition, cash settlements inject funds into the community more quickly, allowing for a faster local recovery.

Are cash settlements the complete answer to the problem then?

If the damage is partial, and does not involve a repair dependency, a cash settlement is a suitable method of claim settlement.

If it is a situation of total loss, a cash settlement might still be appropriate for large Body Corporates and company share schemes. That is because these bodies have a single insurance policy, there is a governance structure in place and a legal or contractual mechanism for the owners to get the remediation work underway.

\footnotetext{
${ }^{890}$ Above n 483.

${ }^{891}$ Cartwright, above n 278 at 207.
} 
For cross-lease properties, fee simple townhouses or small Body Corporates with no Committee or common insurance, cash settlements are not advisable. These multi-unit buildings lack the governance structure to facilitate the reinstatement of the property as a whole.

While cash settlements have clear advantages, these advantages seem to mostly benefit the insurance companies. There are four disadvantages of cash settlements. These are set out below.

\section{No leadership}

The first disadvantage is the lack of leadership. In a large loss situation where the repair dependencies are engaged, owners of a multi-unit building need to work together to agree on a remediation plan. The owners need someone to take the lead on the project. With large Body Corporates and company share schemes, the governance body provides the necessary leadership. However, with cross-lease properties, fee simple townhouses or small Body Corporates with no Committee, there is no one with authority to lead the reinstatement process.

During the Canterbury earthquakes, insurance companies and EQC became de facto leaders. They set up the Shared Property Project where one insurer took the lead over the repairs. This project filled the leadership gap needed to drive the reinstatement process forward. EQC also found that, where owners were offered a managed repair through EQC, they always took that option (provided they were adequately insured) as EQC would lead the project. $^{892}$ So where there was leadership, owners more easily followed and collaborated.

\section{Insufficient expertise}

The second disadvantage is that cash settlements leave the reinstatement process in the hands of inexperienced owners. The research shows that sometimes cross-lease properties attract vulnerable people, including people who are old or unable to make decisions for

${ }^{892}$ Interview with EQC. 
themselves. ${ }^{893}$ Such people would not be able to manage a large construction project like a multi-unit repair. Even when dealing with younger owners, the immensity of the construction project can be overwhelming. One interviewee described how he and his neighbours decided to sell the units to a developer because they determined that a rebuild was going to be a "logistical nightmare". ${ }^{894}$

EQC found that owners were sometimes reluctant to take a cash settlement when that meant there was no one to lead the repair work: ${ }^{895}$

The construction team at EQC is not really set up for managing construction claims for multi-unit buildings so the appetite is to cash-settle those. I need to try to find ways to get ten owners for example agree to a cash settlement. One of the challenges ... [is] that owners were saying we can accept the cash settlement for this damage, but who is going to facilitate the repairs? ... So this puts the customers in a difficult situation because they have the money to do the repairs but who will manage the contract negotiation, who is going to manage the trust fund that needs to be set up between the owners?

The burden of self-management is simply too great.

If a cash payment is proposed in a situation where there is a major repair or a rebuild, the cash payment should incorporate a project-management fee to allow the owners to engage a professional to manage the reinstatement process. Some insurers perceive that if they do not manage the repair or rebuild project themselves, they do not have to pay the cost of project-management.

For example, as discussed above, EQC designed an ad-hoc governance system where they paid for a communication facilitator, a lawyer, the cost to set up a trust account and a project manager. However, EQC only paid these costs if EQC was directly managing the repairs

\footnotetext{
${ }^{893}$ Online survey insurance companies; Interview with Residential Risks Analysis; Interview with RAS.

${ }^{894}$ Interview with Homeowner 2.

${ }^{895}$ Interview with EQC.
} 
and not part of a cash-settlement. ${ }^{896}$ That meant owners were left to manage on their own with no professional assistance. If that was difficult for EQC, how much difficult would it have been for the homeowners?

In Dodds $v$ Southern Response ${ }^{897}$ the Court heard that Southern Response routinely obtained two cost estimates from its project-manager. One was the cost to rebuild or repair the house, called a Detailed Rebuild/Repair Analysis (DRA), and the other was the DRA plus an estimate that included additional costs for internal administration, demolition costs, professional and design fees, project management costs, and a project contingency (the Complete DRA). In the Dodds' case, the DRA showed a rebuild cost of just over $\$ 895,000$ while the Complete DRA came to around $\$ 1,200,000$. According to the Court records, the difference was for internal administration at $\$ 23,000$, demolition at $\$ 64,634.50$, design fees at $\$ 50,716.30$, and a project management cost and a project contingency fee of $\$ 114,678.898$ The Dodds wanted to take a cash settlement to be able to purchase another house. Southern Response only provided them with a copy of the DRA and they settled on that basis. Years later, the Dodds discovered the existence of the Complete DRA and successfully sued Southern Response for the difference. What transpired from the case was that Southern Response never paid project management fees to owners who sought cash settlements. In December 2020, Hon David Clark, the Minister Responsible for the Earthquake Commission, announced a support package for policyholders short-changed by Southern Response (which is a government-owned insurer), estimating that about 3,000 homeowners would qualify for a top-up payment. ${ }^{899}$

The case shows that a managed repair means more cost for the insurer paying projectmanagement fees and allowing for contingencies. But that cost is real to both the insurer

\footnotetext{
${ }^{896}$ Interview with EQC.

${ }^{897}$ Dodds v Southern Response [2019] NZHC 2016, [2019] 3 NZLR 826.

${ }^{898}$ Dodds $v$ Southern Response, above n 897 at [12].

899 "New package for claimants who settled with Southern Response before October 2014" Radio New Zealand (RNZ) (online ed, 14 December 2020).
} 
and the policyholder. Cash settlements need to allow for the cost of project-management, as that is a genuine cost.

To conclude, where there is a total loss or a complicated repair, a cash settlement should always include a project management fee. It is not realistic for EQC and private insurers to expect owners to put their own time and effort into managing the repairs on a voluntary basis.

\section{No certainty of repairs}

The third disadvantage is that sometimes owners do not use the cash for reinstating the properties. The research shows that when owners receive a cash payment, there is a temptation to use the money for something other than repairs. In Canterbury, there was evidence of owners using the cash settlements to pay for holidays, or buy a new car or boat, or landlords investing the funds somewhere else..$^{900}$

This is of real concern in the context of a multi-unit building where one owner's refusal or inability to repair has a domino effect on the other owners. In a large multi-unit building with significant repair dependencies, each unit is part of the whole, so failure to reinstate one unit impacts the collective.

The Report of Public Inquiry into the Earthquake Commission made some remarks on this risk: 901

An as yet unmeasured risk is that cash settlements might not translate to repaired houses. There is vestigial evidence of this occurring in the Kaikōura and Hurunui districts. Calculating the expected number of building consents that might have been anticipated led to a conclusion in the Acuo review that of a possible 500 to 600 building consent applications only approximately 140 were estimated to be earthquake related. The study estimated that about 400 to 500, or the majority of repairs, had not been undertaken by the end of the review period in December 2017.

\footnotetext{
${ }^{900}$ Interview with Residential Risk Analysis; Interview with Lane Neave.

${ }^{901}$ Cartwright, above n 278 at 207.
} 
A cash settlement approach potentially leads to a continuing legacy of unrepaired homes and, in the event of a major natural disaster, homeowners could be faced with the various issues that led to a managed repair programme being undertaken in Canterbury. ${ }^{902}$

In 2020, Treasury recommended to the government that it should undertake a review of the EQC Act, assess the dangers of cash payments as a method of resolving claims, and consider the necessity of another managed repair programme following a large natural disaster event. ${ }^{903}$

The recommendation of this thesis for the establishment of a governance structure would ensure the cash is paid to the representative of the group of owners rather than to each owner individually. They will have an interest as a group to see the units repaired. I believe my proposals to impose a governance structure, mandate compulsory common insurance, and require money be applied for reinstatement of properties would go a long way to ensure the insurance payment is applied to reinstatement.

\section{Risk of insufficient funds}

Finally, the fourth disadvantage is the risk of underpayment. Until repairs start, it is difficult to determine all possible costs and unexpected difficulties. The risk of one owner running out of money is high and will jeopardise the repair process for everyone else.

Here is what one owner had to say about dealing with a cash offer from EQC:904

I refused all offers of a cash settlement, and stuck with it. I'm glad I did because we were constantly asked to sign it off as a full and final settlement. Instead we just wanted them to manage the process of builders and repairs, etc. Had I taken the first cash offer we would now find ourselves short by tens of thousands of dollars.

\footnotetext{
902 Cartwright, above n 278 at 10.

903 Treasury, above $\mathrm{n} 454$ in Appendix 1 at [1.1.5].

${ }^{904}$ Cartwright In the People's Voice, above n 696 at 3.
} 
Another report also highlighted the risk of cash shortfall: 905

In Kaikōura/Hurunui there are indicators that some cash settlements for repairs have not, as yet, been spent on the assessed damage repair. Issues that could arise include difficulty in gaining insurance or selling the affected houses. Additionally, these unrepaired properties will not necessarily withstand future natural disasters and may, in the meantime, add to existing housing issues of damp, cold, or unsanitary accommodation. I hold some concerns that the cash settlement process has left unexamined the full extent of damage, which may prove far greater once the homeowner embarks on repairs. (emphasis added)

This concern led to Treasury recommending to the government that further investigation be made into the Kaikōura cash settlements and that EQC should include further research into the appropriateness of cash settlements. ${ }^{906}$

An insurance broker pointed out that sometimes it was difficult to get the scope of work correct the first time: ${ }^{907}$

If it's a really serious event you're always going to find more damage, and I don't think that's fair. Because insurers know the game; they've been around long enough, they know that if they try and settle full and final it's great for them, but it's not great for the Body Corporate. They are the ones left high and dry because they don't have enough money to repair the building.

[I]n my long history of doing these things, I don't know one claim where the original offer that the insurer wanted to cash settle on has ever been enough. It's always been exceeded, sometimes by double. The most recent one I did it exceeded double. And that was an older style building with a lot of repairs and a very good loss adjuster, mind you. But I couldn't help myself at the end of that claim - I think he adjusted it at over \$1 million and it cost \$2 million.

\footnotetext{
905 Cartwright, above n 278 at 19.

906 Treasury, above n 454 in Appendix 1 at [5.1.3] and [5.1.4].

${ }^{907}$ Interview with Crombie Lockwood.
} 
EQC also found that sometimes the original cost estimates were inadequate: ${ }^{908}$

We had previously cash settled our customers that were in a managed repair with Fletcher EQR (the EQR programme). But what we were finding was that a lot of these multi-unit repairs were actually going overcap during construction. So they would start off as a undercap claim and variations would come in and some of these costs would exceed the EQC cap.

It is common with construction projects that initial cost estimates are exceeded. Sometimes, the work has not been scoped correctly; other times assumptions are misplaced. For example, at the beginning of a project, the engineer might assume good ground, but when construction starts, there are issues with the ground and a much stronger foundation needed. Sometime, the unexpected happens. For example, in 2020, with the Covid-19 pandemic, there was disruption to the construction sector, and work was more difficult or more timeconsuming while complying with the site cleaning and social distancing measures. Cash settlements move the risk of cost escalation from the insurer to the homeowners unless the homeowners are able to go back to the insurer for a top-up.

Evidence from the Canterbury and the Kaikōura earthquakes was that where the claims were settled in cash, some insurers insisted on full and final settlements. ${ }^{909}$ But there is a problem with that. Full and final settlements are a recognised legal mechanism to resolve disputes and document the final agreement between the parties. However, it appears that insurers routinely used this legal mechanism even where there were no real disputes. ${ }^{910}$

If there are genuine disputes, there is no issue with insurers availing themselves of the legal mechanism of a full and final settlement; its use is appropriate. But if there are no disputes,

\footnotetext{
908 Interview with EQC.

${ }^{909}$ Interview with Crombie Lockwood; Cartwright In the People's Voice, above n 696 at 3; ICNZ "Insurance Council welcomes measures to speed up Canterbury settlements" (online ed, 6 June 2018) <www.icnz.org.nz/media-resources/media-releases/single/item/insurance-council-welcomes-measures-tospeed-up-canterbury-settlements>.

${ }^{910}$ Interview with Crombie Lockwood; Cartwright In the People's Voice, above n 696 at 3.
} 
insurers should not be using this mechanism to pay insurance claims. The thesis recommends that legislation be passed to prevent insurers using full and final settlements when settling undisputed claims via a cash payment.

Homeowners are often unfamiliar with legal terms and do not understand the implications of signing a full and final agreement. If there is no dispute with the insurance company, they are unlikely to seek advice from a lawyer who could explain the implications of signing a full and final settlement. If costs escalate during the reinstatement process, homeowners should be able to go back to the insurer to ask for additional funds.

Having to re-open a closed claim would not be attractive to an insurer. Indeed, there is something satisfying in finalising a claim and putting it aside. It also makes parties focus on getting the cost estimate right the first time. Reinsurance treaties could be affected if the insurer needs to go back and ask for more money from the reinsurer. ${ }^{911}$ And there is a risk of homeowners demanding costs that are not insured. To balance the rights of both the insurer and the policyholder, certain conditions could be imposed on considering further costs. The homeowners should be obliged to bring the matter of the unexpected cost to the insurer's attention as soon as they become aware of it and seek approval for the costs prior to incurring them. In that way, if the policy does not provide cover for those, the homeowners can be advised before committing themselves financially.

This measure could be achieved by amending the Insurance Law Reform Act 1985 to introduce a prohibition on full and final cash settlements for undisputed claims, and setting out a process for a policyholder to present further costs to the insurer. Disputed claims could be defined as claims where legal proceedings have been issued or are reasonably apprehended. This test is similar to the test for invoking legal privilege under the Evidence Act $2006,{ }^{912}$ and it has a well-established meaning.

\footnotetext{
911 Assuming the reinsurance retention has been triggered, likely to be the case in a large disaster.

912 Evidence Act 2006, s 56.
} 
Alternatively, insurers could self-regulate by adopting a best practice standard under the Fair Insurance Code. This would be easier but will have a lesser legal force.

\section{Advantages for an insurer-managed repair}

There are some advantages for insurers getting involved with the building repairs. First, it is a good way of controlling costs. Insurers often have business relationships with suppliers or building companies and can achieve better rates through the economies of scale. This is good both for the insurer who is saving the cost and for the homeowner whose policy history shows a lesser claim value. Claims histories are important. Higher losses drive higher premiums going forward.

Second, it is good customer service. Most homeowners either do not have the skill or the time to manage a repair or a rebuild and prefer to leave it to the insurance company to organise the work.

Third, it is a way to avoid fraudulent claims. ${ }^{913}$ If insurers are paying cash, this is usually for the indemnity value of the property. Policies require actual reinstatement before insurers must pay reinstatement costs. A homeowner cannot insist on a cash settlement for full reinstatement unless they are incurring that cost. ${ }^{914}$ This would be counter to the indemnity principle discussed in Chapter III above.

Fourth, if insurers get involved in reinstating a property, there is certainty that the policy money goes into the property rather than toward a holiday or a new car. This benefits the neighbours and the community at large. Insurers also have some reassurance that the repairs have been done and the property is in a state where it can be insured again.

When a disaster happens, and a large number of properties are affected, it is useful to have some comfort that the insurance money is going into reinstating the properties rather than other purchases. A lack of oversight could lead to a deterioration of the housing stock in

913 East v Medical Assurance Society [2014] NZHC 3399 at [27].

${ }^{914}$ East $v$ Medical Assurance Society, above n 913. 
that city, which would have repercussions in the future, either in the sense that insurers might become reluctant to offer cover for that stock or for subsequent owners who discover the damage remains unrepaired.

Hon Gerry Brownlee MP, who was the Minister for Canterbury Earthquake Recovery at the time of the Canterbury earthquakes, spoke in support of managed repairs over cash settlements: ${ }^{915}$

Christchurch was an event that I hope is never repeated anywhere in New Zealand. One of the reasons that EQC decided not to just go out writing cheques for people based on the claims information provided to them, but rather to engage in the actual physical repair of properties under $\$ 100,000$ damage, was to ensure that the overall house stock of Christchurch was not left unattended for decades to come, but rather was repaired to as high a possible a standard. The mere fact that people are able to come back to EQC and say, "I'm not happy with the work that was done on my house", and that they are still able to do that is, I think, testament to that being the right decision that was made.

The issue with cash settlements is that there is no guarantee the money will be used for repairs. Establishing a governance structure for multi-unit buildings will help create an oversight entity that has an interest in seeing that the buildings are repaired.

\section{Addressing underinsurance}

The second measure for improving the insurance claims process is to address underinsurance. This encompasses three aspects. The first is education through public campaigns. The second is specific targeted messages to customers who choose a Sum

915 (29 March 2018) 728 NZPD 2775. 
Insured that is too low. Finally, and probably the most useful change in addressing underinsurance, is for insurers to prompt a review of the Cordell calculator.

Underinsurance, while not prevalent in Canterbury, significantly impacted remediation of multi-unit buildings where it occurred. The repair dependency in a cross-lease property meant that an underinsured owner created a chain reaction, holding up the remediation of the other units.

The introduction of Sum Insured policies in 2013 is likely to create further risk of underinsurance as homeowners are now required to nominate the amount they want to insure their property for.

\section{Difficulty in setting the Sum Insured}

It is difficult for a homeowner to set the Sum Insured at the correct level for five reasons, which I discuss below.

First, homeowners are not well versed in knowing what their policies cover, what limits are in place or what they need cover for. It is a known issue that homeowners do not spend sufficient time reading policy terms and conditions. ${ }^{916}$ For example, homeowners might not appreciate that cover for retaining walls is limited and they might need to arrange more than the automatic cover.

Second, unless they have recently been involved in a construction project, homeowners are unlikely to know how much things cost. Construction costs in New Zealand rose year on year. One insurer gave examples of how much construction costs have changed in ten years, saying that in the main centres the costs increased by 30 per cent; labour costs rose 17 per cent, and plasterboard, cement, and concrete products increased 13 per cent. ${ }^{917}$ It is difficult for a homeowner to keep up with the escalation cost every year. And the reality is that it

\footnotetext{
916 ICNZ “Insurance industry isn't perfect, but general insurers are not unfair” (online ed, 24 June 2019) <www.icnz.org.nz/media-resources/media-releases/single/item/insurance-industry-isnt-perfect-but-generalinsurers-are-not-unfair>. Others found the same problem, see Barry Zalma "Insured's Obligation to Read the Insurance Policy" (online ed, January 2020) <www.irmi.com/articles/expert-commentary/insuredsobligation-to-read-the-insurance-policy>.

${ }^{917}$ IAG New Zealand "Kiwis taking miscalculated risk”, above n 369.
} 
always costs more than the homeowner expects. Architectural and engineering fees have also risen, and they are in a constant state of flux. Costs can also be very different depending on the location and slope of the section. If it costs $\$ 450,000$ to build a house on a flat section, the cost might be different to build a house on a steep slope.

Third, homeowners are likely to estimate the Sum Insured based on what they paid for the property. ${ }^{918}$ This is not the correct measure for the Sum Insured, which is meant to represent the rebuild cost of the property. An estimate based on value is likely to be more in line with an Indemnity Value policy, not a Full Replacement policy. Relevant to multi-unit buildings, there is research to the effect that cross-lease properties are cheaper than fee simple property of the same type. ${ }^{919}$ However, that does not mean the rebuild cost of a cross-lease flat will be cheaper. In fact, one of the interviewees said that the cost to reinstate a cross-lease flat was often out of proportion to the value of the flat. ${ }^{920}$

Fourth, homeowners often do not think to allow for associated costs, such as demolition and removal of debris, professional fees, unforeseen costs such as land damage, or escalation costs.

Fifth, with multi-unit buildings, owners do not think of allowing for collateral damage.

So what are the solutions here?

\section{Public education}

The first recommendation is for insurance companies to adopt and implement a public campaign to educate the public on the impact of underinsurance. Most of them are already doing this. ${ }^{921}$ However, I have not seen a campaign that addresses multi-unit buildings specifically. Multi-unit buildings are likely to be more severely impacted by

\footnotetext{
918 IAG New Zealand "Kiwis taking miscalculated risk", above n 369.

919 Rehm, above n 153.

${ }^{920}$ Interview with Residential Risks Analysis.

921 See for example IAG New Zealand's website www.need2know.org.nz; State Insurance website <www.state.co.nz/house-insurance/home-sum-insured>, last accessed 28 September 2019.
} 
underinsurance than other types of property because of the domino effect. With multi-unit buildings, a mistake in setting the Sum Insured will affect numerous owners.

Having made the recommendation above, I need to point out to a dilemma. Anecdotal evidence suggests that owners perceive the insurance companies' efforts in addressing underinsurance as self-serving. ${ }^{922}$ They believe that insurers want to sell more insurance so they can increase their income, not because it is for the homeowners' benefit. This reinforces that homeowners do not understand how much they need for a rebuild and how to calculate the Sum Insured.

Homeowners often have a skewed view of how the premium is calculated (perhaps thinking it is directly proportional to the Sum Insured) and will choose the minimum they can live with. The possibility of large-scale underinsurance is of concern to the government: ${ }^{923}$

Given the importance of having proper insurance, the government should support the insurance companies' educational campaigns. There needs to be someone independent of the insurance company to reinforce the message that underinsurance is a risk and to assist owners in calculating the Sum Insured.

If my proposal for a governance structure for multi-unit buildings is implemented, along with the requirement for compulsory insurance, this will reduce the risk of underinsurance. It is likely that insurance for a group of multi-unit buildings will be offered as a Material Damage policy product, which usually requires regular, professional valuations. That means owners have the help of a professional in setting the Sum Insured.

\section{Targeted messages to customers}

The second recommendation is for insurance companies to provide targeted messages to customers who intentionally underinsure their properties. If the customer chooses a Sum

\footnotetext{
922 Treasury Report (T2015/1294), above n 355 at 5.

923 (29 March 2018) 728 NZPD 2775.
} 
Insured that is significantly lower than the Cordell estimate, the insurer should point that out to the customer and inform them of the risk of underinsurance and its repercussions.

Insurance companies cannot force customers to change their Sum Insured, and this thesis does not suggest that. This is just another way of educating policyholders, but this time it is targeted at those who intentionally underinsure.

\section{Revision of the Cordell calculator}

At the moment, registered valuers seem to be the best option for a homeowner who is concerned about getting the Sum Insured set at a correct level. However, they come at a cost and not everyone can afford one. Even if they do, the Canterbury earthquakes show that professional valuations are not a complete answer. As detailed in the previous chapter, Body Corporates in Christchurch all required registered valuations to set the Sum Insured and, despite that, most of the Body Corporates ended up being underinsured..$^{924}$

The Cordell calculator is a tool that can be used to assist homeowners with their estimate.

This comes free of cost, which is a good start. However, as detailed in Chapter III, ${ }^{925}$ the Cordell calculator does not appear to be accurate. It requires some refinement to ensure that it correctly allows for inflation, professional fees, escalation fees, and unexpected costs. Homeowners relying solely on the Cordell calculator are likely to be underinsured.

Where the property is a cross-lease or a fee simple townhouse, the calculator should also build in an allowance for collateral damage to acknowledge the existence of repair dependencies. Cross-lease properties and fee simple townhouses with repair dependencies cannot be repaired in isolation. If there is damage that affects the shared elements of the building, this is likely to end up in a higher cost than just repairing the unit.

\footnotetext{
${ }^{924}$ Interview with IAG New Zealand; Interview with Young Hunter; Interview with Grant Shand Barristers and Solicitors.

${ }^{925}$ Chapter III, Part E2.
} 
Cordell is an independent company, but it is used by most (if not all) insurance companies in New Zealand. Insurance companies might be the only parties that have the power to require Cordell to refine the calculator.

\title{
3 No dual handling of claims
}

The third insurance industry measure aims at reducing the layers of decision dependencies by suggesting conflating the two layers of insurance that apply to a natural disaster claim. In other words, where there is EQC Cover, the private insurer should handle the claim.

Natural disaster claims make up a significant number of insurance claims every year. The cover provided by EQC is important to the New Zealand insurance system: ${ }^{926}$

\begin{abstract}
Without EQC cover, international evidence suggests that many New Zealand homeowners would be under-insured or uninsured against catastrophe risks. In such situations, the evidence is also clear that governments face significant pressure to provide ad hoc assistance to those homeowners after large natural disasters. This creates risks and uncertainty for homeowners, insurers and governments.
\end{abstract}

But the Canterbury experience shows that EQC blocked the flow of insurance claims. Insurers were not able to progress claims until EQC finished their assessments. EQC took a long time to assess claims.

Delays took a significant toll on owners. One interviewee homeowner spoke about the trauma: 927

We have often said that our greatest suffering has been the length of time we've had to wait for resolution. That has affected us tremendously emotionally because so much

\footnotetext{
${ }^{926}$ Official Information Act Response 20180116 "EQC Residential Building Cover Cap Limit" - Received 20 March 2018 - Published 7 June 2018 - Treasury <www.treasury.govt.nz/sites/default/files/2018-06/oia20180116.pdf>.

${ }^{927}$ Interview with Homeowner 1.
} 
of our life has been wrapped up in the unresolved and the uncertainty. And it's not something that you just consider occasionally, it's something that is always either in your forethought or in the background of your thought.

We're not talking about waiting an extra hour or day, we're talking months and years. What does that do to a person? It makes you feel completely unvalued, and it makes you feel like they just want you to go away. And some people that we know of in our apartment building have died waiting, and many have become very ill ... it seems to be fairly common in our group of 29 residents, the stress and the strain has without doubt taken a toll to the extent where it's very emotive to say it. But there is blood on the hands of people who are in positions of power and responsibility.

It is an understatement to say that homeowners in Christchurch were disappointed with EQC. EQC performed so poorly that the Government ordered a Public Inquiry to investigate the cause. Leading that inquiry, Dame Silvia Cartwright found that: ${ }^{928}$

As well as the impact on the physical and mental health of the affected populations, a deep mistrust of government (represented by EQC) and a suspicion of motives for actions by those in authority has developed and will take many years to overcome.

\section{A homeowner interviewee said the same: $:^{929}$}

The EQC was terrible in a word. The assessors they got out, didn't seem to know what they were doing initially. Every time you called them you got someone different who told you something different. There was no case manager assigned until really late in the piece and that was to sort of manage it overcap.

The EQC was terrible and the fact that they - when we got an engineer's report and they got one and it agreed with ours, they took that extra step to get a third one. That makes you feel like they are looking for a way to deny everything.

\footnotetext{
928 Cartwright, above n 278 at 17.

${ }^{929}$ Interview with Homeowner 2.
} 
Another made similar remarks: $:^{930}$

Obviously some of the insurance companies got terrible records, but we can't say that at all. It was EQC for some reason being the block as to why you can't go on [with the repair] and get your work done.

EQC [refused to confirm that the property was overcap] I don't know what it was, an extra two years or whatever ... The insurance company agreed to everything and [EQC] still wouldn't put the piece of paper in the office of the insurance company. It was sort of, we felt that was a crowning insult.

For this homeowner, the repairs were completed in August 2019 (nearly nine years after the first earthquake) and the Body Corporate's last financial transaction related to the repair costs was in May 2020. ${ }^{931}$ That was a significant period of waiting.

Following the Canterbury earthquakes, EQC made improvements in the way they handled claims. One of the most significant improvements was to hand over the management of claims to insurance companies during the Kaikōura earthquakes. This was achieved through a Memorandum of Understanding signed by EQC and a number of insurance companies. Although it was not universal (it did not apply to all insurance companies), the agency approach appears to have been more straightforward: 932

Now, one of the learnings from Christchurch has meant that the EQC has taken a different approach to claims in Kaikoura. There, the insurers have managed the whole claim from the beginning, and EQC has just paid out the portion when it's necessary. This has proved to be a very successful method, and I would really like to see this included in the bill as well.

However, some people were against the idea of insurers managing the EQC claims:933

\footnotetext{
${ }^{930}$ Interview with Homeowner 1.

931 Interview with Homeowner 1.

932 (29 March 2018) 728 NZPD 2780.

${ }^{933}$ Cartwright In the People's Voice, above n 696 at 8.
} 
I would not like insurance companies to have full responsibility for handling all claims. There is too much variation across companies, too much profit-motivation and too much scope for treating people differently.

One interviewee raised some interesting arguments against insurers handling claims on behalf of EQC:934

[T] here are two possible points of friction that we need to look at, and I will be looking at that in the Select Committee. One of them is volume. There's no reason to think that IAG, our biggest insurer, is any better equipped than EQC is. They would still have to upscale to deal with 400,000 claims so could may well run into some problems. And the other one is the friction between the Crown and the insurer in terms of accountability. Because insurers ... have quite a lot of incentive to give homeowners the Crowns' money up to the cap [and] the homeowners go sweet, I love this insurer, I'm going to keep insuring with them because they just settled me $120 \%$ of what it's going to cost me to fix. So, whilst there will be disciplines in place, there's incentives, strong incentives pushing the other way. So that's difficult.

There is no perfect system. But the dual handling system is the worst option because it doubles the assessment work, it doubles the time for investigation, it doubles the resources and engineering costs, and it adds another layer of decision dependency. In a large natural disaster event, instead of having all (say) 400,000 claims go through one insurer (EQC), the claims would be split between the eight (or more) insurance companies that could act on behalf of EQC. In my view, there are good reasons why EQC should pass the management of claims to a private insurer.

While I was writing this thesis, in November 2020, EQC announced that it has agreed a new partnership with eight insurance companies ${ }^{935}$ that will see private insurers manage claims on EQC's behalf. ${ }^{936}$ Treasury expects this approach to claims management will

\footnotetext{
934 Interview with Lane Neave.

935 AA Insurance, Chubb, FMG, Ando (Hollard), IAG New Zealand, Medical Assurance Society, Vero Insurance and Tower Insurance.

936 EQC "New natural disaster response model to improve customer experience during the next natural disaster" (2 November 2020) <www.eqc.govt.nz>.
} 
improve efficiencies in managing claims. ${ }^{937}$ The changes take effect from the second quarter of 2021.

The new arrangement is positive. However, it has three shortcomings. The first is that it is not universal. It does not apply to every insurance company. The agreement is with eight private insurers, which represent 20 insurance brands. ${ }^{938}$ EQC says that these insurance companies cover 99 per cent of residential insurance. ${ }^{939}$ So, while it has wide application, it has gaps. A notable party missing from the agreement is AIG New Zealand, a reasonably large insurance company. It is unclear why AIG has not signed up to the agreement.

The second deficiency is that it is not regulated by law, and it is at EQC and the insurers' discretion. The arrangement is a private contract. That suggests that the agreement might be terminated by one or more parties withdrawing from it. I have not seen the Memorandum of Understanding that sets the basis for the new agreement, but I have seen a copy of the Memorandum of Understanding regarding the Kaikōura earthquake. That document gave the parties the ability to terminate their involvement by giving 20 working days' notice. ${ }^{940}$ It would be better if the claims handling model was enshrined into the EQC Act.

Finally, the third weakness is its uncertain application to large-scale natural disasters. On its website, EQC says that "EQC remains the lead insurance agency coordinating the response to any natural disaster [including] coordinating the national insurer response following a natural disaster". ${ }^{941}$ It is unclear whether EQC will revert back to managing claims if there was a large-scale natural disaster. Treasury's inquiry into the possibility of another managed repair suggests that this could be the case. ${ }^{942}$ That would be reverting to a flawed system at a time of the greatest need for streamlining. My recommendation is for the changes to be permanent, stipulated by legislation and of universal application.

\footnotetext{
937 Treasury, above n 454 at [48].

938 EQC “Natural Disaster Response Model” (5 July 2021) <www.eqc.govt.nz>.

939 EQC (@EarthquakeCommission) “We agree, great news for New Zealanders!" <https://twitter.com/EQCNZ/status/1409346166391656448>.

${ }^{940}$ Clauses 14.1 and 14.2.

941 EQC “Natural Disaster Response Model”, above n 938.

942 Treasury, above n 454 in Appendix 1 at [1.1.5].
} 


\section{Better data collection on policies for multi-unit buildings}

The fourth measure to improve the insurance claim process is to collect and store better data about multi-unit buildings. At the point of selling a house policy, insurers already ask a homeowner whether the property is part of a Body Corporate. If it is, then special underwriting rules apply. The fact that the unit is part of a Body Corporate is noted on the policy.

Unfortunately, insurers did not have a similar procedure for cross-lease properties or fee simple townhouses. During the Canterbury earthquakes, there was a delay in resolving claims because insurers did not have a database of the cross-lease properties. ${ }^{943}$ This is important so insurers can prepare appropriately for a multi-unit building claim and deal with the repair and the decision dependencies.

Following the Canterbury earthquakes, insurers have started asking additional questions to determine whether the property is part of a multi-unit complex. ${ }^{944}$ For example, State Insurance's online quote and sales system asks whether there "is there more than one selfcontained dwelling in the home";945 Tower Insurance asks if there more than one selfcontained dwelling on the property; ${ }^{946}$ while AA Insurance asks "what type of building is your house?" and gives the option to select between four choices: freestanding house, apartment, multi-unit in a block of six or fewer, or multi-unit in a block of seven or more. ${ }^{947}$ If selecting the choice of multi-unit with more than seven units, AA Insurance stops the online sales process and asks the purchaser to call and provide further details (no doubt for underwriting purposes). If selecting the choice of a multi-unit building with fewer than six units, a purchaser can continue with the online purchase, but they are asked if there is a

\footnotetext{
${ }^{943}$ Interview with Nine Dots.

${ }^{944}$ Interview with Chair of the ICNZ Personal Lines Committee.

945 State Insurance website <www.secure.state.co.nz/home/Comprehensive\#/your_home>.

946 Tower Insurance website <https://my.tower.co.nz/quote/house/page1>.

947 AA Insurance website <www.online.aainsurance.co.nz>.
} 
Body Corporate structure in place. It appears insurers are starting to ask more questions relevant to multi-unit buildings, which is useful.

The thesis recommends three improvements to this process. The first is building up on insurers' practice of asking further questions and determining at the point of sale the extent of the repair dependencies. This could be as easy as following the questions in the repair dependency calculator proposed below in the thesis, or insurers could make their own questionnaire.

The second improvement is to work with independent third-party information providers such as local councils or Quotable Value ${ }^{948}$ to verify information. Some insurers already do that. For example, Tower's website and questionnaire is already pre-populated with information received from a third party once the interested purchaser inserts the address of the property they want to insure. But the pre-populated information seems to be restricted to the size of the property and construction age and type. This could be expanded to include information about the title. As discussed in Chapter II, each title comes with specific features and that could provide the insurer with further insight at the time of underwriting and, most importantly, at the time of a claim.

The third improvement relates to the storage of that information. Insurers should record that information in a way that it could be easily retrieved from the system when needed. For example, they should be able to say at any given time how many cross-lease properties they insure and the location of these properties. Some insurers already have this capacity for Body Corporates, but not for other types of multi-unit buildings. ${ }^{949}$ The lack of such information was an impediment in enabling the Shared Property Project to proceed. ${ }^{950}$

The data retention is also relevant at claim time because if insurers have the policy noted as a multi-unit building, this should inform all their decisions. For example, they would need to apply a whole-of-building approach to damage assessment and repair. That would flow into the instructions given to the loss adjuster and the engineer. It would also alert the

\footnotetext{
948 A state-owned enterprise which provides valuation and property services.

949 Interview with Chair of the ICNZ Personal Lines Committee.

${ }^{950}$ Interview with Nine Dots.
} 
insurer that they are dealing with a community of owners and that cooperation between owners is required.

If my proposals for a governance structure and single insurance policy is implemented, the necessity of improving data gathering and storing becomes of lesser importance and will be limited to small cross-leases and fee simple townhouses. This is because there will be a single policy for all the units and insurers could access the policy details much more easily.

\section{Prioritising claims for cross-lease properties and fee simple townhouses}

As detailed in Chapter IV, claims for cross-lease properties and fee simple townhouses are harder to manage due to the number of people involved, each having equal say and sometimes a power of veto in relation to their own unit. That is not workable in a situation where the repair dependency is triggered, and a common repair solution needs to be found. If the proposal above for a compulsory governance system and joint insurance is adopted, these properties will be better placed to resolve their insurance claims.

However, for small cross-lease developments and fee simple townhouses, or if the recommendations in the thesis are not adopted, issues remain.

The major impediment in resolving multi-unit building claims in Canterbury was the human element. Most claims involved neighbours being unable to work with each other. ${ }^{951}$ One way to facilitate collective decisions is to try to resolve these claims within the Honeymoon Period ${ }^{952}$ of the recovery process, that is, within the first six months following a disaster. This is the best window of opportunity to get people to cooperate with each other. Research shows that in the first six months following a disaster, people are driven

\footnotetext{
951 Interview with Vero Insurance; Interview with Residential Risk Analysis; Focus Group discussion; Interview with RAS.

${ }^{952}$ For a detailed explanation of the Honeymoon Period see above n 492.
} 
by a spirit of kindness and community. People are more likely to cooperate with the insurance company and with their neighbours in finding a joint repair solution.

Prompt resolution of cross-lease property or fee simple townhouses claims will also minimise situations of assignment and on-selling that complicate the situation. If insurance companies can respond fast, homeowners are likely to be more engaged with rebuilding their lives in the same place rather than abandoning it.

\section{Educational Measures}

Finally, the last set of measures is educational. There are two suggestions here. The first relates to education of homeowners on the responsibilities of owning a cross-lease title or a fee simple townhouse. The second relates to education of lawyers on the implications of selling a damaged unit in a multi-unit building and the effects of assignment of an insurance claim.

\section{Education on cross-lease titles and fee simple townhouses}

Owners of cross-lease properties need to be more educated on the type of property they own and what their obligations are under the cross-lease.

Conveyancing lawyers are best placed to educate the owners. Lawyers already provide (or should provide) advice to owners when they purchase a cross-lease property. Some do it in the form of passive advice (the "here is a copy of the Memorandum of Lease - read it and familiarise yourself with it" kind of advice), ${ }^{953}$ and others do it in the form of active advice, setting out in a letter what the main obligations are that rest with the owner.

${ }^{953}$ Interview with Greenwood Roche. 
Despite that, it seems most cross-lease owners are in fact unaware of the provisions of their lease. ${ }^{954}$ As a result, they breach the covenants.

One way to address this issue is to create a short (one-page), plain-English advice template approved by the New Zealand Law Society that should be given to the homeowners in every case. In other words, standardise the advice given to the homeowners. This should not excuse a lawyer from giving active advice but would provide the minimum required, on a standardised basis and in a format a client could understand.

There should also be a standardised advice template in relation to fee simple townhouses. Lawyers themselves need to become aware of the risk of repair dependencies and what that means to homeowners who purchase these kinds of properties.

\section{Education on assignment of insurance claims and on-selling}

Further education is necessary for conveyancing lawyers, in particular in relation to the parties' rights and obligations under an assigned claim and in case of on-selling. Some academics have suggested that a cross-lease owner who cashes in their insurance policy and then sells the unit is in breach of the covenants. The Toomey Finn research paper says: 955

"As is, where is" sales were a new phenomenon after the Canterbury earthquakes. Despite the best efforts of insurance companies to ensure that their cash settlements resulted in repair, many cash settled owners did not repair but simply put their house on the market for sale. Obviously any such action is a breach of the lease obligation to repair or reinstate.

\footnotetext{
${ }^{954}$ Interview with Residential Risk Analysis; Interview with RAS.

955 Toomey Finn research paper, above n 26 at 84.
} 
A homeowner interviewee disclosed that when he and the other owners sold their properties to a developer, they specifically signed "a release" from their obligations under the Memorandum of Lease. ${ }^{956}$

Conveyancing lawyers need to turn their mind to their client's obligations under the crosslease and advise clients who intend to cash out the policy without reinstating of their obligations to reinstate, and possible consequences of their breach.

Resolution of insurance claims are significantly impacted where the claim is assigned or where the property is sold on an as is where is basis. The more guidance the owners receive on this, the better the outcome of the insurance claims for the other members of the multiunit building community.

If my proposals for a governance structure and a single insurance policy are implemented, there will be no issues with assignment and on-selling because the policy would be in the name of the governance body rather than the individual owner, similar to policies issued for Body Corporates. However, issues will remain for small cross-leases and fee simple townhouses that do not have governance structures.

\section{Summary}

In summary, insurance companies cannot resolve the issue of multi-unit buildings alone. While insurers can take steps to avoid cash settlements where they are not appropriate, educate homeowners on the dangers of underinsurance, and prioritise claims for multi-unit buildings, the most significant changes are in the way multi-unit buildings are built and managed. This will clarify the rights and obligations of owners, which will avoid civil disputes at the time of reinstatement, therefore enabling a more efficient resolution of insurance claims.

\footnotetext{
956 Interview with Homeowner 2.
} 
Insurance follows property rights. An insurer will only have the same rights and obligations as the homeowner they insure, so it is important that property rights are clear and easy to enforce. 


\section{CONCLUSION}

Medium and high-density living is the way of the future. Population growth demands more housing. To better utilise the land, local and national government policies encourage residential intensification. This leads to higher density housing.

\section{Multi-unit buildings have a history of evolving}

Over the years, the property market has responded to increased demand for housing by creating various ways of holding property. Company share schemes used a company structure to hold the land and buildings and sold shares to purchasers that gave them a licence to occupy their unit. These titles only appealed to a small segment of the market because purchasers did not gain ownership of the unit, and it was difficult to get a mortgage. ${ }^{957}$

This prompted property developers, assisted by lawyers, to look for alternatives. One alternative was the creation of a title that almost reversed the company share structure. In a cross-lease, all owners owned the land together in undivided shares. But there were restrictions on subdividing small lots. To get around the restriction, a property lawyer came up with the idea of leasing the flats for a very long term. This enabled purchasers to more easily secure a mortgage. However, the title was complex and owners often misunderstood the nature of their leasehold interest in the flats.

In 1972, the government passed the first Unit Titles Act, creating the infrastructure for the first statutory multi-unit title. At first, the uptake was tentative, with only five Body Corporates created in $1973 .{ }^{958}$ Since then, over 143,000 unit titles have been created. ${ }^{959}$

\footnotetext{
${ }^{957}$ Law Commission, above at n 44 at [1]; Gateway Flats "Submission" (20 March 1972), above n 117; Pidgeon and Tappenden, above $\mathrm{n} 88$ at 1216.

${ }_{958}$ O’Neill, above $\mathrm{n} 241$ at 1.

${ }^{959}$ Fredrickson, above n 1, Appendix A.
} 
However, in the last few years, unit titles have come under criticism for abuses in Body Corporate management, in particular in relation to voting, delayed repairs, and maintenance, and because of large Body Corporate fees. ${ }^{960}$ As a result, property developers have again started looking for alternatives to a Body Corporate structure. One such alternative was to use a fee simple structure, but subject to easements and covenants. ${ }^{961}$

There are no statistics on this yet, but anecdotal evidence is that where property developers propose a new scheme of townhouses, they now prefer fee simple to unit titles. ${ }^{962}$ There are hundreds of fee simple townhouses being built every year. ${ }^{963}$ It seems property developers prefer to create bespoke management solutions for a particular development instead of using the machinery provided by the UTA. ${ }^{964}$

Fee simple properties are the preferred way of holding property in New Zealand. Sale advertisements use the fee simple title as a flag of desirability. Purchasers believe the lack of a Body Corporate will transfer the control over to them. But scholars warned the impression of control in a multi-unit fee simple development is "illusory". ${ }^{965}$ ICNZ cautioned purchasers that sales pitches promoting multi-unit properties without a Body Corporate as saving "time and money" are not always accurate. ${ }^{966}$ When it comes to repairs and resolution of insurance claims, such owners are likely to have a "nasty experience".967 And ADLS warned that legislation governing incorporated societies is likely not suitable to govern property relationships between owners. ${ }^{968}$

\footnotetext{
960 Toomey Finn research paper, above n 26 at 248; France-Hudson, above n 239 at 151; Fonseka, above n 65; Finn, France-Hudson and Toomey, above n 239.

961 Nixon, above n 67 at 25.

962 Fonseka, above n 65.

963 See list above n 62.

${ }^{964}$ Fonseka, above n 65; Nixon, above n 67 at 25.

965 Pidgeon and Tappenden, above n 88 at 1124.

966 ICNZ "Caution”, above n 11.

${ }^{967}$ ICNZ “Caution”, above n 11.

968 ADLS Submission to the Finance and Expenditure Committee on the Unit Titles (Strengthening Body Corporate Governance and Other Matters) Amendment Bill 2021 (25 June 2021) at [3].
} 
The thesis argues that, for communities to function well, they need a governance structure to provide administrative leadership, and terms of reference for their operation, including accessible dispute resolution mechanisms. They also need to recognise the existence of the repair dependencies and make allowance for these by insuring the units together.

When seen through the community lenses, it is easy to see why unit titles performed better in Canterbury than other types of multi-unit buildings. Unit titles are recognised communities, often identified by name, established by law and governed by statutory terms of reference. The owners know that they belong to a community and that they only have a voting power. The owners insure the units together under one insurance policy, recognising the repair dependencies.

Company share schemes are the same: they are recognised communities with an individual identity and name, have a system for common decision-making and recognise repair dependencies by insuring the units together.

By comparison, cross-leases have major problems. The Canterbury experience shows that owners think themselves independent of the other owners in the same development. There is no community and no understanding of the repair and the decision dependencies. The Memoranda of Lease include some management rules and some limited rules for common decision-making. But the terms of the Memoranda are largely unknown, misunderstood or ignored. And when it comes to allowing for repair dependencies, each owner insures their property separately even if their flat is part of a larger building.

Fee simple townhouses with no governing structures are probably the most concerning going forward. There is no community. In fact, property developers deliberately use the fee simple title to avoid community. Advertisements for newly built fee simple townhouses promote the fee simple title and the lack of a governance structure as something to be desired. Repair dependencies are largely ignored, and each owner arranges their own insurance. 
While property developers have been active in creating new ways of holding property, legislation lagged. Unit titles are the only type of multi-unit buildings regulated by targeted legislation. Company share schemes do not have a dedicated Act, although there are some legislative provisions to remove hindrances to their good functioning, ${ }^{969}$ including some comprehensive provisions in the Land Transfer Act 2017. There is no targeted legislation for cross-leases ${ }^{970}$ or fee simple townhouses.

\section{The Canterbury earthquakes evidenced a systemic problem with multi-unit buildings}

The Canterbury experience showed that there was a systemic problem with multi-unit buildings.

Out of the group of multi-unit buildings, unit titles performed the best during the Canterbury earthquakes. They were not perfect but, compared to cross-leases and some fee simple townhouses, they had fewer problems.

There was no feedback from the Canterbury earthquakes in relation to company share schemes, but I expect company share schemes would have performed in a similar way to unit titles because they have a comparable management model.

The image below illustrates the situation of a unit title structure and a company share scheme during the Canterbury earthquakes.

\footnotetext{
969 Companies Amendment Act 1964; Companies (Amendment) Act (No 2) 1965; Income Tax Act 2007, s 31D; Land Transfer Act 2017, Part 3, subpart 6.

${ }^{970}$ Pidgeon and Tappenden, above n 88 at 1216; Toomey Finn research paper, above n 26 at 17.
} 


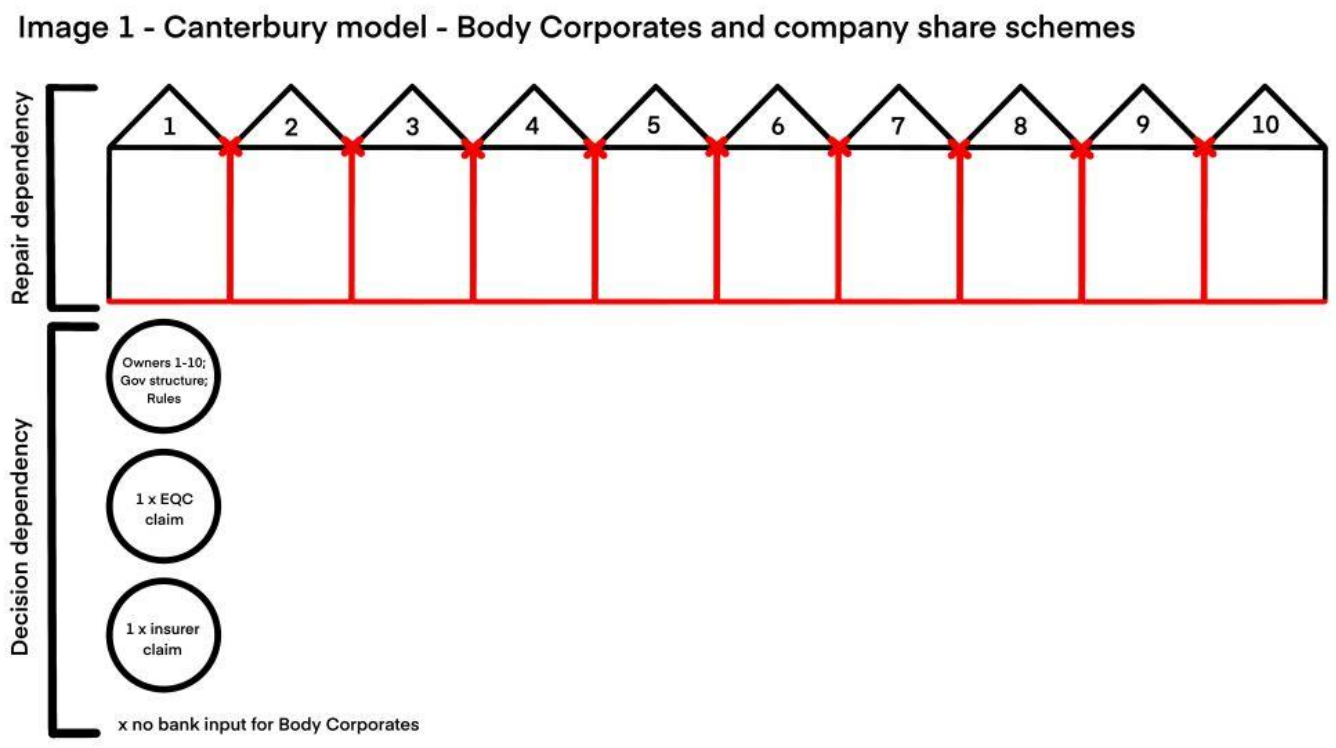

There was a governance structure providing administrative leadership. The UTA prescribed the process for making decisions. Owners had to make decisions together in accordance with the process set out by the UTA. They had to present a common decision to the insurer, so there was only one owner "bubble". The Body Corporate had a representative who liaised with the insurance company and with EQC. Because there was only one insurance policy for the whole building, there was only one EQC claim, and only one insurance claim with the private insurer. The bank had no say about what happened with the insurance proceeds if the Body Corporate intended to use the money for reinstatement.

By comparison, owner communities in cross-leases and fee simple townhouses developments lacked cohesion. The image below provides a visual representation of the decision and the repair dependencies. 


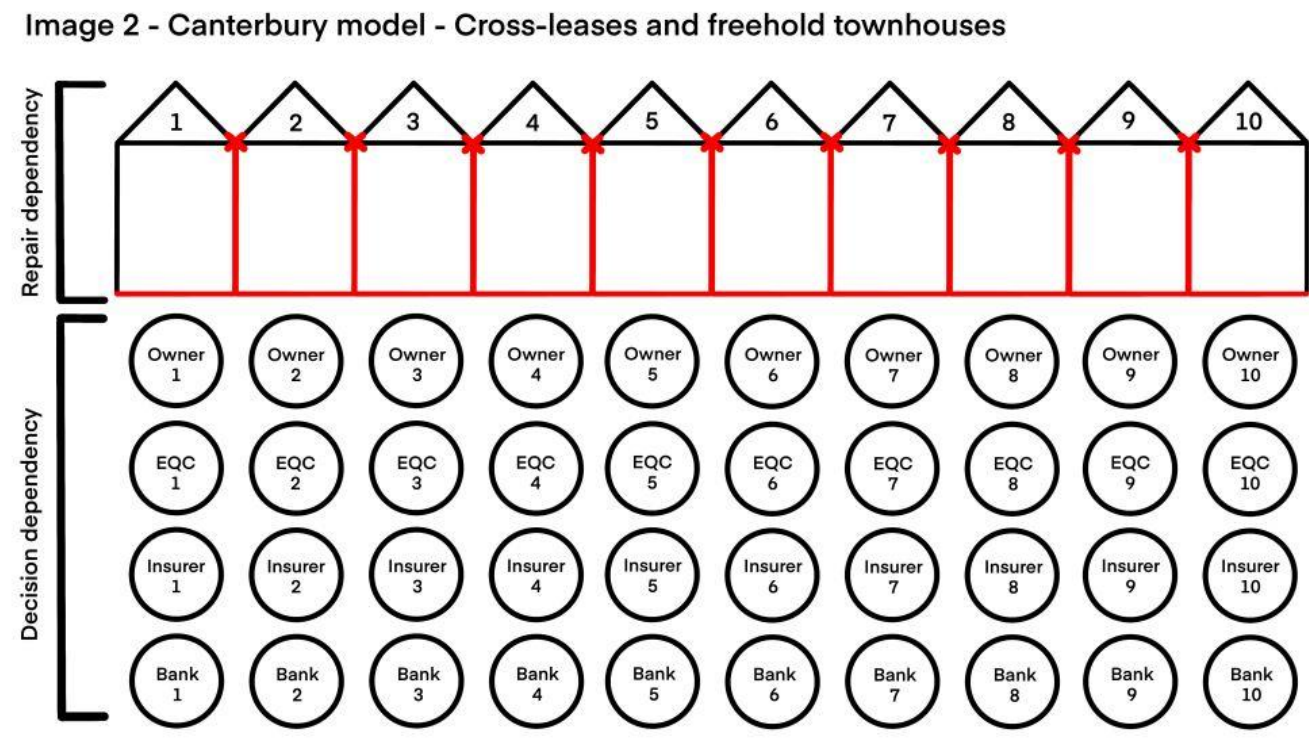

Each owner saw themselves as independent of the other owners in the community. Each insured their unit separately. This led to multiple policies, with different levels of cover; multiple insurers; and multiple policyholders acting independently of each other. Where the earthquake caused damage to shared elements of the building, owners struggled to find joint solutions, handicapped by lack of a pre-determined process and of leadership. Sometimes, the Memoranda of Lease required unanimity of decision, and this was difficult to achieve. The repair dependencies meant that sometimes owners were not able to reinstate their unit without affecting the neighbouring units. Where foundations were damaged, or a rebuild was necessary, engineers often recommended a joint reinstatement process.

It became obvious for insurers and owners alike that a whole-of-building approach was needed. This required the cooperation of all involved. Cooperation was difficult to achieve where there was no pre-determined process and no governance structure. Some owners simply refused to engage with the process; others wanted to keep matters private, especially where they did not have sufficient money to reinstate their unit; others were absent and not interested in the repairs; some just wanted to take the cash and sell the property for someone else to worry about; and others had personal issues that burdened them - like a divorce, a death in the family, financial uncertainty, or a disability. 
There was a large human "bubble" in the middle of the legal issues. It was not just a matter of technical expertise and method of reinstatement but also of managing human relationships at the worst of times. And, with the passage of time, these relationships worsened as people became disillusioned with the recovery, and inward looking. The Honeymoon Period was over very quickly.

For cross-leases and fee simple townhouses, there were four layers of decision dependencies: the owners, EQC, the insurer, and the bank. Each had a say in what happened to the unit. And within each layer or bubble of dependency, there were several sub-layers. The owners might have been a couple, who needed to agree between themselves first; or they might have been elderly and under a power of attorney, so someone else had to be involved; or they might have had a son or a daughter, or a lawyer, or a claim advocate assisting them with the claim. Within the owner bubble, there would have been different layers of decision dependencies.

The same was with the EQC bubble. EQC would have had a claims handler, an engineer, a loss adjuster and a project manager involved in each claim. Everyone had a role to play in assisting EQC in making a decision. Significantly, EQC had separate claims for each of the unit owners, because there were multiple policies and therefore each policy had to be treated on its own terms.

The insurer bubble resembled the EQC bubble and had a claims handler, a loss adjuster, a project-manager, an engineer, and sometimes other professionals such as geotech engineers or lawyers. At the insurer level, there was also multiplicity of insurers because units were insured with separate insurers. Each had its own internal process and methods of resolving claims. Even if an insurance company insured more than one unit in the development, they would have needed to open separate claims for each unit because the policies were individual to the homeowners involved. At the insurer level, insurers also had to agree between themselves as to how to repair the property, adding a double layer of decision dependency. 
The banks had the right to direct that the insurance money be paid toward the mortgage rather than repair. This would have been fatal to a joint repair effort.

EQC and the private insurers had to face the conundrum of keeping all the bubbles level, and everyone in agreement with each other. It proved difficult. Every little movement, even small caprices, could burst a bubble and cause the arrangement to fall over. To use a Biblical parable, these houses were built on sand.

The image above illustrates the immensity of the human element: the multiple decision dependency bubbles. This image only shows a case of ten units, but cross-leases and fee simple developments can be much larger. One interviewee referred to a cross-lease development in Christchurch that had 40 units. ${ }^{971}$ That would have increased the decision dependency bubbles four times over.

\section{So how can the situation be resolved?}

From the research, and at least as far as insurance claims are concerned, there is no need to change the way existing unit titles and company share schemes operate. The only thing the thesis recommends is to strengthen the governance structure for Body Corporates (or the decision dependency bubble, if we are to use the illustrations above as visual guides). Within the bubble, owners need to be empowered to make decisions in an efficient, sensible way that is not open to manipulation. The thesis supports the current efforts to amend the UTA to allow for a better management system.

For cross-leases and fee simple townhouses, we have to accept that we cannot change the repair dependencies. The buildings are what they are. Where we can improve is to address the decision dependencies. The thesis argues that this can be done by addressing each of the four layers of dependencies. I detail these below.

${ }^{971}$ Interview with Residential Risk Analysis; see also Gerry Brownlee in (2 July 2014) 700 NZPD 19128, above $n 524$. 
The owner layer needs to become one big bubble combining all owners. This can be achieved by creating a governance structure and mandating decision-making through voting (similar to unit titles).

The EQC layer needs to be merged into the insurer layer. The good news is that this has already happened through an agreement between EQC and private insurers. The thesis suggests that this agreement is provided for in the legislation and made universal rather than left to chance.

The insurer layer also needs to reduce from multiple insurers to one insurer. During the Canterbury earthquakes, the insurers instinctively agreed to a project that achieved exactly that: they appointed a lead insurer to make decisions for them all. It proved effective, and its success can be explained by the reduction in the decision dependencies. Unknowingly, the insurers created a platform to remove the double layer of dependency that existed between them. The thesis proposes that legislation be adopted to impose a requirement for compulsory common insurance for cross-leases and fee simple townhouses with significant repair dependencies and that have more than five units.

Finally, the bank layer can be removed if there is a governance structure that could administer the insurance proceeds for the benefit of the whole community. This can be achieved through legislation imposing a requirement that cross-leases and fee simple townhouses use the insurance money toward reinstatement and, if they do that, the bank cannot direct payment of the insurance proceeds toward the mortgage.

The illustration below shows the proposed model for existing cross-leases and fee simple townhouses. 
Image 5 - Proposed model - Existing cross-leases and freehold townhouses

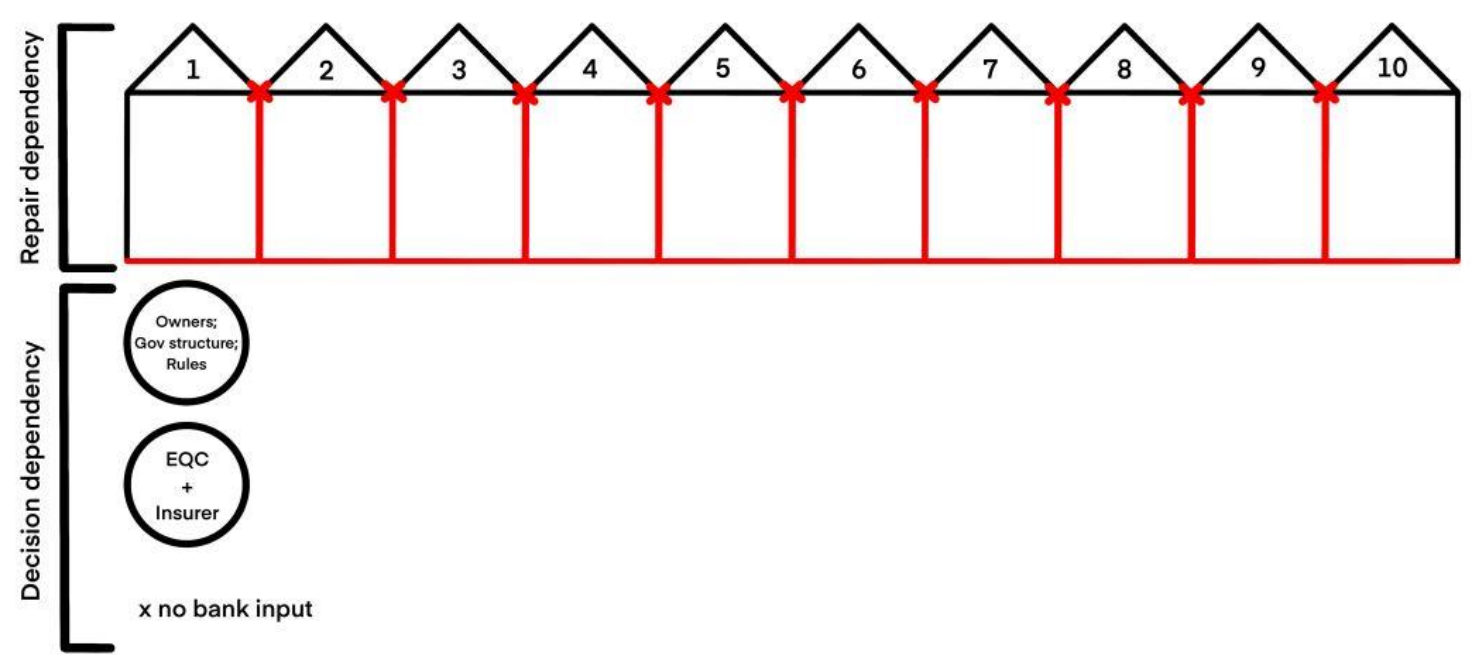

A closer examination reveals that it looks similar to the model applicable to unit titles. Owners need to make decisions within the owner bubble, led by a governance body and assisted by the existence of administrative rules. There should be only one insurance policy, which would lead to there being only one insurer bubble. Legislation should mirror the provisions of the UTA removing the bank's ability to direct payment of the insurance proceeds toward a mortgage when the money is used for reinstatement.

However, there are some differences. For example, the thesis proposes a lighter governance structure, with roles that are more limited to those of a Body Corporate. Notably, the thesis does not suggest imposing levies for maintenance - although these could be considered, if necessary.

The thesis does not suggest changes to small cross-lease and fee simple townhouse developments with five or fewer units. More research is necessary to determine the right balance between proper management and excessive administration.

The thesis suggests adopting a legislative package to facilitate the management of multiunit buildings generally. For want of a better term, the proposals are grouped under the name Administrative Rules and include implying minimum rights and obligations in 
existing easements; laying out a process for repairing buildings in close proximity to each other, and access to an affordable dispute resolution process. The aim of the legislative provisions is to anticipate what could go wrong between owners of multi-unit buildings and pre-empt disputes by charting a new way of living in a community. The reality is that New Zealand is moving toward a future of housing intensification and there will be more people living in close proximity to each other. Owners need to learn new ways of living in this environment. Legislation can show the way by establishing guiding principles.

But the experience of the Canterbury earthquakes should also encourage us to look for better ways of building. Intensification can be achieved without repair dependencies. The thesis recommends that new cross-leases, fee simple townhouses, and company share schemes are built with their own building envelope and in a way that they can be repaired in isolation of the other units. Building resilience is important in a country like New Zealand, where natural disasters occur with regular frequency. With increased density of housing comes the risk of collateral damage. And this creates uncertainty in terms of insurance cover, and significant personal turmoil for the people who are displaced out of their homes.

New Zealand's short history of multi-unit buildings shows that there is an act of balancing building techniques that aim to reduce the cost of building a home (and keep homes affordable) and the social and legal complexities that can arise where buildings are built with repair dependencies. Indeed, the way some cross-leases were built (with significant repair dependencies or strata style) enabled cost savings to the developer, ${ }^{972}$ but the numerous problems that followed between neighbours highlighted a human cost. A similar trend emerges now with fee simple townhouses and FSST titles that are built with significant repair dependencies and have complicated legal titles. ${ }^{973}$ In my view, they will become problematic in the future. In the past, the lower dollar value properties have resulted in a higher human cost. So, where is the balance? I believe that by adopting the proposals suggested in the thesis, a balance can be achieved. Building in close proximity

\footnotetext{
972 Thomas, above n 142 at 1138; McMorland and Gibbons, above n 133 at 131.

${ }^{973}$ Information on FSST titles, above n 96.
} 
to each other is possible and achieves the desired intensification and prudent use of land, but without undermining the owners' interests. I have illustrated the proposal in the image below. The owners remain in charge of their affairs, knowing that there are no shared elements with the unit next door. There are no repair dependencies and therefore no decision dependencies. However, these buildings will benefit from the Administrative Rules, that is, a legislative package aimed at assisting multi-unit building owners in finding a way to repair a property in close proximity to another, and from the dispute resolution mechanisms. The EQC and the insurer layers are merged because this proposal has already been adopted while I was writing the thesis.

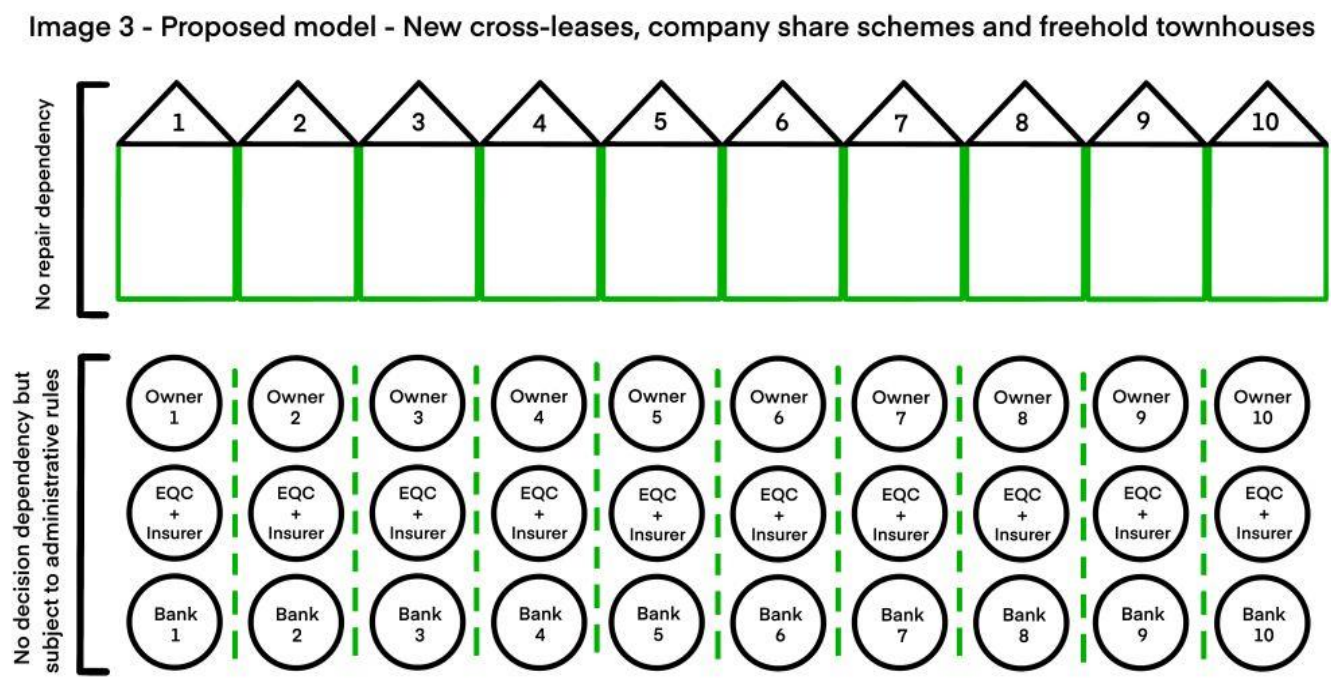

Finally, there will be situations where, either for cost-saving reasons or for other reasons, property developers might still want to build multi-unit buildings with shared elements. This is possible, but the thesis proposes that, in those cases, the properties should be unit titled and subject to the provisions and the protection afforded by the UTA. Properties built strata style are always going to share elements, so they are included in the same recommendation - that they should only be built under a unit title structure. I have created an illustration to show this proposal below. 
Image 4 - Proposed model - New townhouse style properties with repair dependencies

(1)

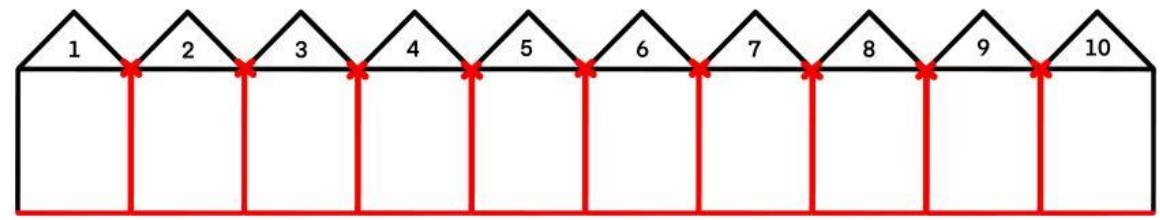

Only as unit titles
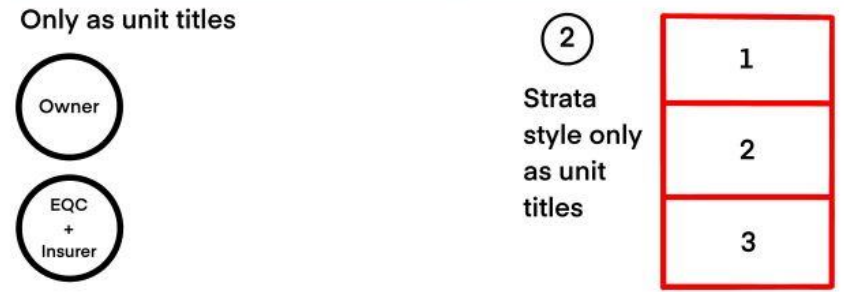

$\mathrm{x}$ no bank input

The insurance industry has an important role to play

Aside from changes to the property law framework, it is clear the insurance industry has an essential part to play in improving resolution of multi-unit building claims. The guiding principle is the whole-of-building approach. This recognises that multi-unit buildings are characterised by repair dependencies. The guiding principle informs every step of the process, from issuing a policy to effecting reinstatement. The thesis argues that insurance companies need to make inquiries at the time they sell a policy on whether the building is a multi-unit building. Using a pre-established questionnaire, they need to determine the extent of the repair and the decision dependencies and note them on the policy. Insurance companies should have records of all cross-lease properties and fee simple townhouses they insure, in the same way they keep records for unit titles. These records must be easy to access.

Accurate records inform a proper assessment of damage. A note on the policy identifying a property as a multi-unit building prompts the correct damage assessment process. The insurer must instruct the loss adjuster or the engineer who assesses the damage to consider the property as a whole. The reinstatement process then follows the same approach. This 
includes being prepared to be involved in another Shared Property Project if the thesis' proposals above are not followed.

One point of concern is about cash settlements. Cash settlements are undesirable where there is no governance structure. Owners do not always use the insurance money toward reinstatement. The thesis suggests that insurers consider, but not be forced into, becoming involved with the reinstatement process in these situations. Cash settlements are suitable where there is a governance structure or when the repairs are minor and do not affect the neighbouring units.

Cash settlements for undisputed claims should not be on a full and final basis. The thesis suggests that legislation be introduced preventing insurance companies from settling claims in cash by way of full and final settlements, unless proceedings have been issued or are reasonably apprehended. It is often the case with construction projects that unforeseen circumstances arise. A full and final cash settlement shifts the risk from the insurer to the homeowners. This is detrimental. Where the cash settlement is short of the actual cost of reinstatement, the homeowners should be able to go back to the insurer for an additional payment.

Cash settlements should allow for project-management fees where the reinstatement process requires it. Multi-unit buildings are often large complexes and owners are not able to manage large-scale construction projects.

Insurers can improve the resolution process by prioritising multi-unit building claims and taking advantage of the Honeymoon Period of six months when it is easier to gain consensus between owners.

Finally, the insurance industry needs to be involved in addressing underinsurance. This involves educational campaigns. The government should independently support such initiatives to account for those owners who believe the insurance industry's promotions are self-serving. Where the insurance companies can have the greatest input is in prompting a 
revision of the Cordell calculator. This is a good tool, but it falls short on a few aspects. With some revision it can be transformed into a more accurate calculator.

\section{There is a need for further education}

The thesis also suggests some further educational measures. Owners need to be familiar with the type of multi-unit building they own, preferably before they buy into it. They need to understand the rights and limitations of their title, the fact that they are buying into a community, and what is expected of them. Conveyancing lawyers are best placed to educate owners at the time they purchase the properties. The thesis suggests a standardisation of advice given to owners of cross-lease properties and fee simple townhouses.

Lawyers also need to turn their minds to the suitability of easements in dealing with significant repair dependencies. Until a law is passed to imply terms, the rights and obligations of owners, their ease of enforcing the rights depends on the lawyer drafting the easements and the covenants.

Conveyancing lawyers should also become more informed on the implications of assignment of insurance claims for damaged properties and on-selling properties on an as is where is basis. With multi-unit buildings, there are sometimes legislative or contractual requirements on the vendor to use the insurance money toward reinstatement; selling the property without reinstating could be in breach of those obligations.

\section{The thesis can be applied outside insurance claims}

The thesis calls for several changes to the way multi-unit buildings are built, managed, and insured. The suggestions in relation to property law changes are of value even if there are no insurance issues. A cross-lease or a fee simple townhouse development might be affected by something excluded by an insurance policy, like weathertightness issues or coastal erosion for example. Such damage is not insured. Owners will need to find a 
common solution to repair the damage. Without a governance structure, joint repairs will be difficult. The property law measures propose a framework for better administration of multi-unit building communities in general.

Housing intensification brings with it new ways of living. Owners need to learn how to live well in higher density housing. The thesis argues that it is time for guiding principles to be set out in the legislation. Housing is too important to be left unaddressed. Legislation should provide direction and clarity, and support community living. In turn, this will provide a better platform when it comes to insurance claims and effecting reinstatement of properties. 


\section{APPENDIX A: SUMMARY OF RECOMMENDATIONS}

The thesis made a number of recommendations. For ease of reference, they are listed below, along with the page reference for the discussion.

\begin{tabular}{|c|c|c|}
\hline Recommendations & $\begin{array}{l}\text { Discussion } \\
\text { locator }\end{array}$ & $\begin{array}{l}\text { Type of } \\
\text { recommendation }\end{array}$ \\
\hline $\begin{array}{l}\text { Any new properties built strata style should be } \\
\text { unit titled. }\end{array}$ & Ch V, Part A1 & Legislative \\
\hline $\begin{array}{l}\text { Any new unit in a cross-lease property, fee simple } \\
\text { townhouse development and company share } \\
\text { scheme should have their own building envelope } \\
\text { (in other words, should not share structural } \\
\text { elements with another unit). As a minimum units } \\
\text { should not have shared foundations. }\end{array}$ & Ch V, Part A1 & Legislative \\
\hline $\begin{array}{l}\text { If developers intend to create a development with } \\
\text { shared accessory buildings or facilities (such as } \\
\text { parks, pools, carparks), the developer should } \\
\text { create a governance structure to manage the } \\
\text { common property. The homes / units should still } \\
\text { be built independent of each other. }\end{array}$ & Ch V, Part A1 & Legislative \\
\hline $\begin{array}{l}\text { If developers intend to create a development } \\
\text { where units share construction elements, the new } \\
\text { development should be unit titled. }\end{array}$ & Ch V, Part A1 & Legislative \\
\hline $\begin{array}{l}\text { Existing cross-leases and fee simple townhouses } \\
\text { with six or more units and with significant repair } \\
\text { dependencies should have a governance structure } \\
\text { and compulsory common insurance. In matters } \\
\text { involving common property, the law should } \\
\text { prescribe a procedure for making decisions } \\
\text { through voting (similar to unit titles). The } \\
\text { governance structure should be limited to the } \\
\text { precincts which share construction elements. }\end{array}$ & Ch V, Part A4 & Legislative \\
\hline $\begin{array}{l}\text { The governance structures should have their } \\
\text { powers and duties set out in the legislation. These }\end{array}$ & Ch V, Part A4 & Legislative \\
\hline
\end{tabular}




\begin{tabular}{|c|c|c|}
\hline $\begin{array}{l}\text { should include the obligation to keep a register of } \\
\text { owners, organising meetings, arranging common } \\
\text { insurance, and applying the insurance money } \\
\text { toward reinstatement (the legislative provisions } \\
\text { related to insurance should mirror the provision } \\
\text { applicable to unit titles). }\end{array}$ & & \\
\hline $\begin{array}{l}\text { The legislation should specify that banks cannot } \\
\text { direct the insurance money toward payment of } \\
\text { insurance if the money is applied for } \\
\text { reinstatement. }\end{array}$ & Ch V, Part A4 & Legislative \\
\hline $\begin{array}{l}\text { The governance structure should have the } \\
\text { authority to bind owners and enter into contracts. }\end{array}$ & Ch V, Part A4 & Legislative \\
\hline $\begin{array}{l}\text { Legislation be passed to enable a better } \\
\text { management of cross-leases and fee simple } \\
\text { townhouses, regardless of their size and level of } \\
\text { repair dependency. The legislative package should } \\
\text { include implying default provisions in existing } \\
\text { easements; setting a process for repairing } \\
\text { properties which share elements or are in close } \\
\text { proximity with each other; and improve access to } \\
\text { a dispute resolution system. }\end{array}$ & Ch V, Part A4 & Legislative \\
\hline $\begin{array}{l}\text { Legislation should be adopted prohibiting } \\
\text { insurance companies from settling claims in cash } \\
\text { on a full and final basis unless the parties are in } \\
\text { dispute and legal proceedings have commenced or } \\
\text { are reasonably apprehended. }\end{array}$ & Ch V, Part C1 & Legislative \\
\hline $\begin{array}{l}\text { Policyholders who have received a cash } \\
\text { settlement should be able to go back to the insurer } \\
\text { if the funds are insufficient to reinstate. }\end{array}$ & Ch V, Part C1 & Insurance reform \\
\hline $\begin{array}{l}\text { Cash settlements need to include project- } \\
\text { management fees for repairs which are more than } \\
\text { minor. }\end{array}$ & Ch V, Part C1 & Insurance reform \\
\hline $\begin{array}{l}\text { The EQC Act should be amended to state that the } \\
\text { private insurers would handle claims on behalf of } \\
\text { EQC for all claims going forward. }\end{array}$ & Ch V, Part C3 & Legislative \\
\hline
\end{tabular}




\begin{tabular}{|c|c|c|}
\hline $\begin{array}{l}\text { Insurance companies should prompt Cordell to } \\
\text { revise their calculator. }\end{array}$ & Ch V, Part C2 & Practical \\
\hline $\begin{array}{l}\text { Insurance companies should run public campaigns } \\
\text { on the danger of underinsurance, in particular as } \\
\text { they relate to multi-unit buildings. }\end{array}$ & Ch V, Part C2 & Practical \\
\hline $\begin{array}{l}\text { Government should also run public campaigns on } \\
\text { the danger of underinsurance. }\end{array}$ & $\begin{array}{l}\text { Ch III, Part } \\
\text { E2 and Ch V, } \\
\text { Part C2 }\end{array}$ & Practical \\
\hline $\begin{array}{l}\text { Insurance companies should point out the risk of } \\
\text { underinsurance to a customer which sets the Sum } \\
\text { Insured lower than the Cordell estimate. }\end{array}$ & Ch V, Part B2 & Practical \\
\hline $\begin{array}{l}\text { Insurance companies should collect and better } \\
\text { utilise data on policies for multi-unit buildings. } \\
\text { They should determine at the point of issuing a } \\
\text { policy whether the property is a multi-unit } \\
\text { building and the level of the repair dependency; } \\
\text { note the policy appropriately; have the data easily } \\
\text { retrievable; use the data when the policies are } \\
\text { triggered to ensure that the buildings are assessed } \\
\text { as a whole. }\end{array}$ & Ch V, Part B4 & Practical \\
\hline $\begin{array}{l}\text { Insurance companies should prioritise the claims } \\
\text { for multi-unit buildings and strive to resolve them } \\
\text { within the first six months following the loss to } \\
\text { take advantage of the Honeymoon Period. }\end{array}$ & Ch V, Part B5 & Practical \\
\hline $\begin{array}{l}\text { NZLS should create a one-page standard template } \\
\text { advice to be given to any purchaser of a cross- } \\
\text { lease property or a fee simple townhouse. }\end{array}$ & Ch V, Part C1 & Practical \\
\hline $\begin{array}{l}\text { Lawyers should advise purchasers of cross-lease } \\
\text { properties and fee simple townhouses of their } \\
\text { obligations under the Memorandum of Lease, any } \\
\text { potential breach of covenants if they fail to } \\
\text { reinstate or if they sell as is where is. }\end{array}$ & Ch V, Part C1 & Practical \\
\hline
\end{tabular}




\begin{tabular}{|c|c|c|}
\hline $\begin{array}{l}\text { There should be further education of lawyers on } \\
\text { assignment of insurance claims, on-selling, and } \\
\text { potential risks arising out of repair dependencies. }\end{array}$ & Ch V, Part C2 & Practical \\
\hline $\begin{array}{l}\text { The government should adopt provisions which } \\
\text { make it easier for standalone cross-lease } \\
\text { properties to convert to fee simple. }\end{array}$ & Ch V, Part A4 & Legislative \\
\hline $\begin{array}{l}\text { The government should implement the proposed } \\
\text { changes to the UTA and strengthen the } \\
\text { governance of Body Corporates. }\end{array}$ & $\begin{array}{l}\text { Ch V, Part A3 } \\
\text { and Ch II, } \\
\text { Part F }\end{array}$ & Legislative \\
\hline $\begin{array}{l}\text { The government should consider whether the } \\
\text { threshold for unit titles required to have a } \\
\text { Committee should be six units rather than nine } \\
\text { units. }\end{array}$ & Ch V, Part A3 & Further research \\
\hline $\begin{array}{l}\text { The government should consider the Party Wall } \\
\text { etc Act } 1996 \text { (UK) as a prototype for a New } \\
\text { Zealand-adapted Act. }\end{array}$ & Ch V, Part A4 & Further research \\
\hline $\begin{array}{l}\text { The government should consider Ontario's } \\
\text { dispute resolution system when reviewing the } \\
\text { current provisions in the UTA. }\end{array}$ & Ch V, Part A4 & Further research \\
\hline $\begin{array}{l}\text { More research is necessary to determine whether } \\
\text { unit titles, cross-leases and fee simple townhouses } \\
\text { that have five or fewer units should have a } \\
\text { compulsory governance body. }\end{array}$ & Ch V, Part A3 & Further research \\
\hline $\begin{array}{l}\text { More research is necessary to determine whether } \\
\text { the government should also impose obligations for } \\
\text { a long-term maintenance plan for large cross- } \\
\text { leases and fee simple townhouses with significant } \\
\text { repair dependencies. }\end{array}$ & Ch VI & Further research \\
\hline
\end{tabular}

APPENDIX B: REPAIR DEPENDENCY CALCULATOR

Below is the questions flowchart proposed for the repair dependency calculator, along with a table of values. 


\section{Questions flowchart}

The calculator asks users a number of questions in a particular order, and with a particular weight attached to each answer or parameter. ${ }^{974}$ Users do not see the individual weight of the parameters, only the final score. The questions proceed as follows:

1. What type of legal title is the property?

a. Fee simple: $\mathrm{T} 1=0$ points.

1. Is the property standalone or has shared elements with another building?

a. Standalone: $\mathrm{RD} 1=0$ points.

i. Does it have a shared driveway?

1. Yes: RD2 $=5$ points

2. No: RD3 $=0$ points

End of questions. Calculate total.

b. Has some shared elements. If this is selected, then follow with further questions:

2. Does it have a shared driveway?

1. Yes: $\mathrm{RD} 2=5$ points

2. No: RD3 $=0$ points

3. Does it have partially shared roof or a fully shared roof?

a. Partially shared roof: RD4 $=2.5$ points

b. Fully shared roof: RD5 $=5$ points

4. How many shared walls does it have?

a. Only one shared wall: $\mathrm{RD} 6=2.5$ points

b. More than one shared wall: RD7 $=5$ points

5. How is the foundation built? This is very important, so please make proper inquiries before answering.

${ }^{974} \mathrm{~T}=$ title; $\mathrm{RD}=$ repair dependency $; \mathrm{G}=$ governance. 
a. The foundations are built completely independent from the other units: RD8 $=5$ points. If this option is selected, then jump to last question:

i. Are there any written rules applicable to the management of the common property or the shared building elements? This could be, for example, specific easements put on the title, Administrative Rules, or a constitution.

1. No: $\mathrm{G} 3=15$ points

2. Yes: $\mathrm{G} 4=0$ points

End of questions. Calculate total.

b. The foundations are common or have partially shared elements: RD9 $=40$ points

6. How is insurance arranged for the property?

a. All units are insured under one single insurance policy (common insurance): $\mathrm{RD} 10=0$ points

b. Each owner is arranging their own insurance (separate insurance): $\mathrm{RD} 11=10$ points

7. Is there an active owners' committee or an agreed way to make decisions about the common property or the shared elements of the building?
a. No: $\mathrm{G} 1=20$ points
b. Yes: G2=0 points

8. Are there any written rules applicable to the management of the common property or the shared building elements? This could be, for example, specific easements put on the title, Administrative Rules, or a constitution.
a. No: $\mathrm{G} 3=15$ points
b. Yes: $\mathrm{G} 4=0$ points End of questions. Calculate total. 
b. Cross-lease: $\mathrm{T} 2=25$ points

1. Is the property standalone or has shared elements with another building?

a. Standalone: $\mathrm{RD} 1=0$ points

i. Does it have a shared driveway?

1. Yes: RD2 $=5$ points

2. No: RD3 $=0$ points

End of questions. Calculate total.

b. Has some shared elements. If this is selected, then follow with further questions.

2. Does it have a shared driveway?

1. Yes: RD2 $=5$ points

2. No: RD3 $=0$ points

3. Does it have partially shared roof or a fully shared roof?

a. Partially shared roof: RD4 $=2.5$ points

b. Fully shared roof: RD5 $=5$ points

4. How many shared walls does it have?

a. Only one shared wall: $\mathrm{RD} 6=2.5$ points

b. More than one shared wall: RD7 $=5$ points

5. How is the foundation built? This is very important, so please make proper inquiries before answering.

a. The foundations are built completely independent from the other units: RD8 $=5$ points. If this option is selected, then jump to last question:

i. Are you aware of your rights and obligations set out in the Memorandum of Lease and the restrictions imposed by this document?

1. No: $\mathrm{G} 3=5$ points

2. Yes: G4=0 points

End of questions. Calculate total. 
b. The foundations are common or have partially shared elements: RD9 $=40$ points

6. How is insurance arranged for the property?

a. All units are insured under one single insurance policy (common insurance): $\mathrm{RD} 10=0$ points

b. Each owner is arranging their own insurance (separate insurance): RD11 $=10$ points

7. Is there an active owners' committee or an agreed way to make decisions about the common property or the shared elements of the building?
a. No: $\mathrm{G} 1=5$ points
b. Yes: $\mathrm{G} 2=0$ points

8. Are you aware of your rights and obligations set out in the Memorandum of Lease and the restrictions imposed by this document?
a. No: $\mathrm{G} 3=5$ points
b. Yes: $\mathrm{G} 4=0$ points
End of questions. Calculate total.

c. Unit title: $\mathrm{T} 3=10$ points

1. Is the property standalone or has shared elements with another building?

a. Standalone: $\mathrm{RD} 1=0$ points

i. Does it have a shared driveway?

1. Yes: RD2 $=5$ points

2. No: RD3 $=0$ points

End of questions. Calculate total.

b. Has some shared elements. If this is selected, then follow with further questions.

2. Does it have a shared driveway?

1. Yes: RD2 $=5$ points 
2. No: RD3 $=0$ points

3. Does it have partially shared roof or a fully shared roof?

a. Partially shared roof: RD4 $=2.5$ points

b. Fully shared roof: RD5 $=5$ points

4. How many shared walls does it have?

a. Only one shared wall: $\mathrm{RD} 6=2.5$ points

b. More than one shared wall: $\mathrm{RD} 7=5$ points

5. How is the foundation built? This is very important, so please make proper inquiries before answering.

a. The foundations are built completely independent from the other units: RD8 $=5$ points. If this answer is selected, then jump to last question: Are you aware of the rights and obligations set out in the Unit Titles Act?

i. No: $\mathrm{G} 3=5$ points

ii. Yes: $\mathrm{G} 4=0$ points

End of questions. Calculate total.

b. The foundations are common or have partially shared elements: RD9 $=35$ points

6. How is insurance arranged for the property?

a. All units are insured under one single insurance policy (common insurance): RD10 $=0$ points

b. Each owner is arranging their own insurance (separate insurance): RD11 = 10 points

7. Is there an active Body Corporate Committee to make decisions about the common property or the shared elements of the building?
a. No: $\mathrm{G} 1=25$ points
b. Yes: G2=0 points

8. Are you aware of the rights and obligations set out in the Unit Titles Act? 

a. No: $\mathrm{G} 3=5$ points
b. Yes: $\mathrm{G} 4=0$ points
End of questions. Calculate total.

\section{d. Company share properties: $\mathrm{T} 4=25$ points}

1. Is there an active Board of Directors to make decisions about the property?
a. No. $\mathrm{G} 1=40$ points
b. Yes: $\mathrm{G} 2=0$ points

2. Is there a company constitution that deals with how the properties will be managed?
a. No: $\mathrm{G} 3=35$ points
b. Yes: $\mathrm{G} 4=0$ points 


\section{Table of values}

The values of the parameters are summarised in the table below.

\begin{tabular}{|c|c|c|c|c|c|}
\hline Parameter & Code & Fee simple & Cross-lease & Unit title & $\begin{array}{l}\text { Company } \\
\text { share }\end{array}$ \\
\hline Title & $\mathrm{T}$ & $\mathrm{T} 1=0$ & $\mathrm{~T} 2=25$ & $\mathrm{~T} 3=10$ & $\mathrm{~T} 4=25$ \\
\hline Standalone & RD1 & 0 & 0 & 0 & $\mathrm{X}$ \\
\hline $\begin{array}{l}\text { Shared } \\
\text { driveway }\end{array}$ & RD2 & 5 & 5 & 5 & $\mathrm{X}$ \\
\hline $\begin{array}{l}\text { No shared } \\
\text { driveway }\end{array}$ & RD3 & 0 & 0 & 0 & $\mathrm{X}$ \\
\hline $\begin{array}{l}\text { Partial joint } \\
\text { roof }\end{array}$ & RD4 & 2.5 & 2.5 & 2.5 & $\mathrm{X}$ \\
\hline Full joint roof & RD5 & 5 & 5 & 5 & $\mathrm{X}$ \\
\hline One party wall & RD6 & 2.5 & 2.5 & 2.5 & $\mathrm{X}$ \\
\hline $\begin{array}{l}\text { More than one } \\
\text { party wall }\end{array}$ & RD7 & 5 & 5 & 5 & $\mathrm{X}$ \\
\hline $\begin{array}{l}\text { No shared } \\
\text { foundations }\end{array}$ & RD8 & 5 & 5 & 5 & $\mathrm{x}$ \\
\hline $\begin{array}{l}\text { Shared } \\
\text { foundations }\end{array}$ & RD9 & 40 & 40 & 40 & $\mathrm{X}$ \\
\hline $\begin{array}{l}\text { Common } \\
\text { insurance }\end{array}$ & RD10 & 0 & 0 & 0 & $\mathrm{X}$ \\
\hline $\begin{array}{l}\text { Separate } \\
\text { insurance }\end{array}$ & RD11 & 10 & 10 & 10 & $\mathrm{X}$ \\
\hline
\end{tabular}




\begin{tabular}{|l|l|l|l|l|l|}
\hline $\begin{array}{l}\text { Governance } \\
\text { structure }\end{array}$ & G1 & 20 & 5 & 25 & 40 \\
\hline $\begin{array}{l}\text { No governance } \\
\text { structure }\end{array}$ & G2 & 0 & 0 & 0 & 0 \\
\hline $\begin{array}{l}\text { Governance } \\
\text { rules }\end{array}$ & G3 & 0 & 0 & 0 & 0 \\
\hline $\begin{array}{l}\text { No governance } \\
\text { rules }\end{array}$ & G4 & 15 & 0 & 0 & 35 \\
\hline
\end{tabular}




\section{BIBLIOGRAPHY}

1 Cases

Australia

The University of Newcastle v GIO General Ltd (1995) 8 ANZ Insurance Cases 61-281 (NSWSC).

New Zealand

AMI Insurance v Legg [2017] NZCA 321, [2017] 3 NZLR 629.

Attorney-General v Body Corporate 68792 (2007) 8 NZCPR 165.

Avonside Holdings Ltd v Southern Response [2014] NZCA 483, (2014) 18 ANZ Insurance Cases 62-040.

Body Corporate 398983 v Zurich Australian Insurance [2013] NZHC 1109, (2013) 17 ANZ Insurance Cases 61-972.

Body Corporate 335089 v Vero Insurance New Zealand and Body Corporate 341154 v Vero Insurance New Zealand [2020] NZHC 2353.

Body Corporate 78462 v IAG New Zealand [2016] NZHC 320, 2016 WL 947184.

Bruce \& ors v IAG New Zealand [2019] NZCA 590.

Bryant v Primary Industries Insurance Co Limited 2 NZLR 142 (CA).

C \& S Kelly Properties v Earthquake Commission [2015] NZHC 1690.

Dewes \& ors v IAG New Zealand \& ors [2019] NZHC 2270.

Davy v Scarrott [2016] NZHC 1791, (2016) 17 NZCPR 523.

Dodds v Southern Response [2019] NZHC 2016, [2019] 3 NZLR 826.

Douglas v Cammock HC Hamilton, CP48/99, 4 August 1999. 
Doig v Tower Insurance [2019] NZCA 107, (2019) 20 ANZ Ins Cas 62-222.

Dominion Finance Group Ltd (in Rec and Liq) v Body Corporate 382902 [2012] NZHC 3325, (2012) 7 NZ ConvC 96-003.

Douglas \& Williams v Cammock HC Hamilton CP48/99, 4 September 1999.

E\&E v IAG New Zealand [2019] CEIT 0013.

Earthquake Commission v Insurance Council of New Zealand [2014] NZHC 3138, [2015] 2 NZLR 381.

East v Medical Assurance Society New Zealand [2014] NZHC 3399.

EQC Action Group v Earthquake Commission [2016] NZHC 1335.

Evans v IAG New Zealand [2020] NZHC 1326.

Estate D B Ferguson v Walsh (1999) 4 NZ ConvC 193,032.

Firm PI 1 Ltd v Zurich Australian Insurance [2014] NZSC 147, [2015] 1 NZLR 432.

Fitzgerald v IAG New Zealand [2018] NZHC 3447.

GvEQC [2021] CEIT 0010.

Gv EQC and Vero Insurance [2021] CEIT 0056.

Goodier v Earthquake Commission [2019] NZHC 2176.

Guardian Retail Holdings Limited v Buddle Findlay [2013] NZHC 1582, [2013] NZAR 988.

Heale v IAG New Zealand [2019] NZHC 2829.

Inicio Ltd v Tower Insurance [2020] NZHC 90. 
Jarden v Lumley General Insurance (NZ) Ltd [2016] NZCA 193, (2016) 19 ANZ Insurance Cases 62-104.

Kraal v EQC [2015] NZCA 13, [2015] 2 NZLR 589.

Kristinsson v Southern Response [2017] NZHC 456.

L\&M v EQC [2019] CEIT 0036.

Little v IAG New Zealand (2010) 16 ANZ Insurance Cases 61-860.

M\&M v IAG New Zealand [2019] CEIT 0047.

Marriott v Vero Insurance [2013] NZHC 3120.

Mathieson v Tower Insurance [2020] NZHC 136.

Mediaworks TV v Staples [2019] NZCA 133, [2020] 2 NZLR 372.

Medical Assurance Society v East [2015] NZCA 250, [2015] 18 ANZ Insurance Cases 62-074.

McEwan v Curtis [2015] NZHC 2258.

McLean v IAG New Zealand [2013] NZHC 1105.

Mills v Body Corporate 47522 [2013] NZHC 1854.

Molyneux Holdings v IAG New Zealand [2007] NZCA 254.

Moore v IAG New Zealand [2020] NZCA 319.

Myall v Tower Insurance [2017] NZHC 251.

Myall v Tower Insurance [2017] NZCA 561, [2017] 19 ANZ Insurance Cases 62-163.

O’Loughlin v Tower Insurance [2013] NZHC 670, [2013] 3 NZLR 275.

OM Hardware Ltd v Body Corporate 303662 [2015] NZHC 190, (2015) 15 NZCPR 921. 
Parkin v Vero Insurance [2015] NZHC 1675.

Prattley Enterprises v Vero Insurance [2016] NZCA 67, [2016] 2 NZLR 750.

Prattley Enterprises v Vero Insurance [2016] NZSC 158, [2017] 1 NZLR 352.

QBE Insurance (International) v Wild South Holdings [2014] NZCA 447, [2015] 2 NZLR 24.

Re Earthquake Commission [2011] 3 NZLR 695.

Re McKay [2018] NZEnvC 180.

Ridgecrest v IAG New Zealand [2014] NZSC 129, [2015] 1 NZLR 40.

Robin v IAG New Zealand [2018] NZHC 1464.

Rout v Southern Response [2013] NZHC 3262.

Rozee v Zhang [2019] NZHC 2165, (2019) 20 NZCPR 547.

Sadat v Tower Insurance \& EQC [2017] NZHC 1550.

Schneideman v Barnett [1951] NZLR 301.

Self-Realization Meditation and Healing Centre v IAG New Zealand \& ors [2019] NZHC 763.

Sleight v Beckia Holdings \& ors [2020] NZHC 2851.

Smith v Claims Resolution Service [2019] NZHC 1013.

Southern Response v Avonside Holdings [2015] NZSC 110, [2017] 1 NZLR 141.

Insurance Council of New Zealand v Christchurch City Council [2013] NZHC 51, 17 ANZ Insurance Cases 61-956.

Thomson v Dorchester Apartments Ltd [2015] NZHC 2476. 
TJK (NZ) v Mitsui Sumitomo Insurance [2013] NZHC 298, 17 ANZ Insurance Cases 61968.

Tower Insurance v Skyward Aviation 2008 [2014] NZSC 185, [2015] 1 NZLR 341.

Turvey Trustee v Southern Response [2012] NZHC 3344, [2013] 17 ANZ Insurance Cases $61-965$.

University of Canterbury v Insurance Council of New Zealand [2013] NZCA 609, 18 ANZ Insurance Cases 62-001.

University of Canterbury v Insurance Council of New Zealand [2014] NZSC 193, [2015] 1 NZLR 261.

Wv Southern Response [2020] CEIT 0020.

Wellington v Hickling HC New Plymouth M19/95, 10 April 1995.

Weir v IAG New Zealand [2019] NZHC 3282.

Wilson v Turnwald (1997) 3 NZ ConvC 192, 559.

World Vision of New Zealand Trust Board v Seal [2004] 1 NZLR 673.

Xu \& Diamantina Trust v IAG New Zealand [2017] NZHC 1964, 19 ANZ Insurance Cases $62-160$.

Xu \& Diamantina Trust v IAG New Zealand [2018] NZCA 149, 20 ANZ Insurance Cases $62-177$.

Xu \& Diamantina Trust v IAG New Zealand [2019] NZSC 68, [2019] 1 NZLR 600.

Young v Tower Insurance [2016] NZHC 2956, [2018] 2 NZLR 291.

Zurich Australian Insurance v Body Corporate 398983 [2013] NZCA 510. 
The United Kingdom

Abbahall Ltd v Smee [2003] 1 All ER 465.

Carterv Boehm (1766) 3 Burr 1905.

Castellain v Preston (1883) 11 QBD 380 (CA).

Corbett v Hill (1870) LR 9 Eq 671.

Leakey v National Trust for Places of Historic Interest or Natural Beauty [1980] QB 485.

Wayne Tank and Pump Co v Employers Liability Assurance Corporation [1974] 1 QB 57 (CA).

2 Legislation, Regulations, Bills, and Codes of Practice

\section{Australia}

Conveyancing (Strata Titles) Act 1961(NSW).

Owners Corporations Act $2006(\mathrm{Au})$.

Strata Schemes Management Act 1996 (NSW).

Canada

Condominium Act, 1998

Germany

Civil Code 1900.

First Housing Act 1950.

New Zealand

Accident Compensation Act 2001.

Building Act 1991 (repealed).

Building Regulations 1992. 
Canterbury Earthquakes Insurance Tribunal Act 2019.

Canterbury Earthquake Recovery Act 2011 (repealed).

Civil Defence Emergency Management Act 2002.

Companies Amendment Act 1964 (repealed).

Companies (Amendment) Act (No 2) 1965.

COVID-19 Response (Further Management Measures) Legislation Act 2020.

Earthquake and War Damage Act 1944 (repealed).

Earthquake Commission Act 1993.

Earthquake Commission Amendment Act 2019.

Evidence Act 2006.

Fencing Act 1978.

Flat and Office Ownership Bill 1972.

Income Tax Act 2007.

Land Subdivision in Counties Act 1946 (repealed).

Land Subdivisions in Counties Amendment Act 1958.

Land Transfer Act 2017.

Land Transfer Regulations 2002 (revoked).

Land Transfer Regulations 2018.

Local Government Act 1974.

Local Government Amendment Act 1979. 
Marine Pollution Act 1974.

Municipal Corporations Act 1954 (repealed).

Municipal Corporations Amendment Act 1958.

New Zealand Bill of Rights Act 1990.

Official Information Act 1982.

Overseas Investment Amendment Act 2018.

Property Law Act 1952 (repealed).

Property Law Act 2007.

Property Law Amendment Act 1968.

Resource Management Act 1991.

Retirement Villages Code of Practice.

Residential Tenancies Act 1986.

Telecommunications (Property Access and Other Matters) Amendment Act 2017.

Unit Titles Act 1972 (repealed).

Unit Titles Act 2010.

Unit Titles Amendment Act 1979.

Unit Titles (Strengthening Body Corporate Governance and Other Matters) Amendment Bill 2021.

Unsolicited Electronic Messages Act 2007.

War Damage Act 1941. 
Weathertight Homes Resolution Services Act 2006.

\section{The United Kingdom}

The Party Wall etc Act 1996.

\section{Scotland}

The Tenements (Scotland) Act 2004.

\section{Singapore}

Housing and Development Act 1960.

\section{Books and Chapters}

Tom Bennion "Introduction" in Elizabeth Toomey and JF Burrows (eds) New Zealand Land Law (3rd ed, Thomson Reuters, eBook, ProQuest Ebook, 2017).

John Birds Birds’ Modern Insurance Law (8th ed, Sweet \& Maxwell, London, 2010).

David Brown "Easements, Profits and Covenants" in Elizabeth Toomey and JF Burrows (eds) New Zealand Land Law (3rd ed, Thomson Reuters, eBook, ProQuest Ebook, 2017).

Robert Chambers An Introduction to Property Law in Australia (3rd ed, Thomson Reuters, Sydney, 2013).

Malcolm Clarke Policies and Perceptions of Insurance Law in the Twenty-First Century (Oxford University Press, Oxford, 2005).

Jeremy Finn and Elizabeth Toomey (eds) Legal Response to Natural Disasters (Thomson Reuters, Wellington, 2015).

Peter M. Gerhart Property Law and Social Morality (Cambridge University Press, Cambridge, 2014).

Thomas Gibbons Unit Titles Act and Practice (2nd ed, LexisNexis, Wellington, 2015). 
ER Hardy Ivamy General principles of Insurance Law (6th ed, Butterworths, London, 1993).

John Lowry and Philip Rawlings Insurance Law Doctrines and Principles (2nd ed, Hart Publishing, Oregon, 2005).

Bevan Marten Maritime Law in New Zealand (Thomson Reuters, eBook, ProQuest Ebook, 2016).

Judith-Anne Mackenzie Land Law (16th ed, Oxford University Press, Oxford, 2016).

DW McMorland and Thomas Gibbons McMorland and Gibbons on Unit Titles and Cross Leases (LexisNexis, Wellington, 2013).

Robert Merkin Insurance Law - An Introduction (Informa, London, 2007)

Robert Merkin and Chris Nicholl (eds) Colinvaux's Law of Insurance in New Zealand (Thomson Reuters, Wellington, 2014).

Robert Merkin and Chris Nicholl (eds) Colinvaux's Law of Insurance in New Zealand (2nd ed, Thomson Reuters, Wellington, 2017).

Robert Merkin and Raoul Collinvaux Collinvaux's Law of Insurance (8th ed, Sweet \& Maxwell, London, 2006).

Joanna Pidgeon and Susan Tappenden "Unit Titles" in Elizabeth Toomey and JF Burrows (eds) New Zealand Land Law (3rd ed, Thomson Reuters, eBook, ProQuest Ebook, 2017).

Margaret Jane Radin Boilerplate: The Fine Print, Vanishing Rights and the Rule of Law (Princeton University Press, eBook, JSTOR Ebook, 2013).

Megarry Robert and others The Law of Real Property (8th ed, Sweet \& Maxwell, London, 2012).

Carol Rose Property and Persuasion: Essays on the History, Theory and Rhetoric of Ownership (Westview Press, Boulder, 1994). 
AA Tarr and JA Kennedy Insurance Law in New Zealand (2nd ed, The Law Book Company, Sydney, 1992).

Rod Thomas "Cross leases" in Elizabeth Toomey and JF Burrows (eds) New Zealand Land Law (3rd ed, Thomson Reuters, eBook, ProQuest Ebook, 2017).

Elizabeth Toomey and JF Burrows (eds) New Zealand Land Law (3rd ed, Thomson Reuters, eBook, ProQuest Ebook, 2017).

\section{Journal Articles}

Sarah Blandy, Jenifer Dixon and Ann Depuis "Theorising power relationships in multiowned residential developments: Unpacking the bundle of rights" (2006) 43 Urban Studies 2365 .

Simon Connell "Community insurance versus compulsory insurance: competing paradigms of no-fault accident compensation in New Zealand" (2019) 3 Legal St 499.

DF Dugdale "Shared Ownership of Land" [1999] NZLJ 29.

Hazel Easthope and Bill Randolph "Principal-agent problems in multi-unit developments: The impact of developer actions on the on-going management of strata titled properties" (2016) Environment and Planning Journal 1829.

Jeremy Finn, Ben France-Hudson and Elizabeth Toomey "Damage, Destruction, Distress: Shared Ownership Debacles" (2016) 22 CantaLR 57.

Ben France-Hudson "Review of the Unit Titles Act 2010: A Missed Opportunity" (2017) 15 Otago LR 147.

Henry Holderness "Replacement Cover in Residential Property Insurance and the Canterbury Earthquakes 2010-2011” (2017) 23 NZBLQ 3. 
Anthony P Molloy “Aspects of Flat-Owning Companies” [1969] NZLJ 44. Felicity Powell "Urban earthquake events and businesses: learning from the 2007 Gisborne earthquake in New Zealand" (2010) 25 AJEM 54.

CG van der Merwe “Apartment Ownership” (1994) VI International Encyclopaedia of Comparative Law.

$\mathrm{Lu} \mathrm{Xu}$ "Managing and Maintaining Flatted Buildings: Some Anglo-Scottish Comparisons" (2010) 14(2) Edinburgh L Rev 236.

\section{Media Articles}

Chris Barton "What Kaikōura Taught Us About Wellington" New Zealand Geographic (online ed, February 2017).

Hunter Calder "Local Focus: Hamilton high-rise houses on the rise" The New Zealand Herald (online ed, 21 January 2019).

Geoff Cooper "Embrace housing density, it will breathe life into New Zealand's cities" Stuff (online ed, 26 September 2019).

Joelle Dally "Eleventh-hour offer may save Cranmer Courts" Stuff (online ed, 25 August 2012).

Richard Deakin "Rising Insurance pressure for Wellington apartment owners" CoreLogic (online ed, 9 October 2019) <www.corelogic.co.nz>.

Dileepa Fonseka "Review or tweak? Government confronts body corporate review" Stuff (online ed, 22 November 2020).

Debrin Foxcroft "Neighbours at war over fences, blocked driveways and dog poo" Stuff (online ed, 30 August 2018). 
Anne Gibson "Cross-lease properties can be 'ticking time-bombs', warns top lawyer" Stuff (online ed, 20 September 2018).

Anne Gibson "Deck battle turns into nightmare" The New Zealand Herald (online ed, 13 August 2013).

Morten Gjerde "NZ needs a proactive plan for high-density housing" Newsroom (online ed, 14 June 2017).

Michael Hayward "Government to pay for failed repairs to earthquake-hit Canterbury homes" Stuff (online ed, 15 August 2019).

Maarten Holl “Court Doesn’t Hold Key to Dorchester Apartments Deadlock - Judge” Stuff (online ed, 8 August 2016).

"Homeowners left in limbo after faulty EQC repairs" Radio New Zealand (RNZ) (online ed, 1 March 2018).

"Hundreds of people buy faulty homes as EQC confirms potential billion-dollar hole" The New Zealand Herald (online ed, 17 April 2018).

Kami Huyse "Crisis Management: The Four Emotional Stages of Disaster" Zoetica (online ed, 23 March 2007) <www.zoeticamedia.com>.

ICNZ "Insurers caution home buyers to be wary of insurance pitfalls for multi-unit buildings" Scoop Business (press release, 27 January 2021).

IAG New Zealand "Kiwis taking miscalculated risk with sum insured" (online ed, 10 September 2019) <www.iag.co.nz/latest-news/articles/Kiwis-taking-miscalculated-riskwith-sum-insured.html>.

Toby Manhire "Cranmer Courts: Christchurch heritage reduced to mulch" Noted (online ed, 4 October 2012).

John McCrone "Did EQC save big on Christchurch land claims?” Stuff (online ed, 29 July 2016). 
Liz McDonald "Little Pidgeon Bay cottage smashed by tsunami waves" Stuff (online ed, 14 November 2016).

Liz McDonald "Waterfront apartment owners at war over splitting insurance payout" Stuff (online ed, 12 January 2019).

Rob Mitchell "Fears rising insurance and body corp costs could make apartment living unsustainable" Stuff (online ed, 4 May 2019).

"New package for claimants who settled with Southern Response before October 2014"

Radio New Zealand (RNZ) (online ed, 14 December 2020).

New Zealand government "Telco property bill access passes third reading" Business Scoop (press release, 11 April 2017).

Gabriel Olano "Insurance Council warns about risks of housing complexes" Insurance Business NZ (online ed, 28 January 2021).

Cameron Preston "Cam Preston says many Christchurch residents still have good reason to 'carp \& moan' five years on from the first earthquake" (online ed, 3 September 2015).

Julie-Ann Ross "High-density housing has its place” Stuff (online ed, 12 March 2020).

Jamie Small "Christchurch family's rebuild botched, can't sell land tied in cross lease" Stuff (online ed, 19 October 2017).

Cullen Smith "Cranmer Court demolition all 'bad news"” The New Zealand Herald (online ed, 5 October 2012).

Nick Smith “Apartment \& townhouse law to be strengthened” Beehive.co.nz (press release, 22 December 2016).

Marta Steeman "Insurance for new house builds and major renovations should be compulsory, submitters" Stuff (online ed, 10 August 2019). 
Rob Stock "Insurers warn of hidden risk in buying into a housing complex with no body corporate" Stuff (online ed, 27 January 2021).

Rob Stock "Why do insurance customers have to pay excess?" Stuff (online ed, 4 April 2018).

Jenee Tibshraeny "Reconstruction underway on just 7 of 154 'complex' multi-unit Canterbury buildings 4 years after biggest earthquake" Interest (online ed, 24 February 2015).

Nick Truebridge "Seven elderly residents at Sumner apartments died waiting for settlement" Stuff (online ed, 12 August 2016).

Duncan Webb "Multi-unit dwellings the big insurance nightmare" Stuff (online ed, 16 September 2013).

"Why $80 \%$ of Singaporeans live in government-built flats" The Economist (online ed, 8 July 2017)

Kirst Wynn “Consumer Watch: Pitfalls for unit-buyers” Stuff (online ed, 2 June 2013).

Anan Zaki "Kaikōura quake insurance claims to be completed this year" Stuff (online ed, 9 January 2018).

\section{Online Sources}

"5 Things to Know About Public Housing in Singapore" (18 June 2019) <www.gov.sg>.

Advertisement for a strata fee simple property at West Hills <www.https://westhills.co.nz/view-by-price\#price-0>.

Association of British Insurers "Motor Insurance" (online ed, undated) <www.abi.org.uk>. 
Australian Institute of Professional Counsellors "Common Stages of Disaster Recovery" (26 May 2014) Counselling Connection <www.counsellingconnection.com>.

BRANZ "Medium density housing " $<$ branz.co.nz/mdh $>$.

BRANZ "What is medium-density housing?" (October 2017) <www.branz.co.nz>.

"Business Insurance" <www.business.gov.au>.

Cambridge Dictionary <www.dictionary.cambridge.org>.

Canterbury Earthquake List <www.courtsofnz.govt.nz/the-courts/high-court/high-courtlists/earthquake-list-christchurch/>.

The Canterbury Earthquake Recovery Authority (29 March 2011) Department of the Prime Minister and Cabinet <www.mbie.govt.nz>.

Christchurch City Council "Types of subdivisions" <www.ccc.govt.nz>.

Constitution of Hobsonville Point development in Auckland <www.hprs.co.nz/wpcontent/uploads/2016/11/HPRS-Constitution-December-2016.pdf>

Employers' Liability insurance $<$ www.gov.uk $>$.

Erskine Residents Society Incorporated, Incorporated Societies register number 2735872 <www.is-register.companiesoffice.govt.nz>.

EQC "Buying or selling a home, or just transferring an EQC claim?” <www.eqc.govt.nz>.

EQC "EQC and Fletcher EQR announce repair timeframes" (20 December 2011) <www.eqc.co.nz>.

EQC “Getting your claims reviewed” (23 October 2020) <www.eqc.govt.nz>.

EQC “How we are settling Kaikōura claims” (22 August 2019) <www.eqc.govt.nz>.

EQC “Joint Statement” (22 March 2018) <www.eqc.govt.nz>. 
EQC “Multi-Unit Buildings FAQs” (27 January 2021)<www.eqc.govt.nz>.

EQC “Multi-Unit Buildings: Multi-unit buildings FAQs - expanded tab” (12 July 2019) <www.eqc.govt.nz>.

EQC "Multi-unit buildings" (1 March 2013) <www.eqc.govt.nz>.

EQC “Multi-Unit Buildings” (12 July 2019)<www.eqc.govt.nz>.

EQC "New natural disaster response model to improve customer experience during the next natural disaster" (2 November 2020) <www.eqc.govt.nz>.

EQC “Natural Disaster Response Model” (5 July 2021) <www.eqc.govt.nz>.

EQC (@EarthquakeCommission) “We agree, great news for New Zealanders!”

<https://twitter.com/EQCNZ/status/1409346166391656448>.

EQC Annual Report 2010-2011 <www.eqc.govt.nz>.

EQC Annual Report 2012-2013 <www.eqc.govt.nz>.

EQC Annual Report 2018-2018 <www.eqc.govt.nz>.

GeoNet "Kaikōura/Story" <www.geonet.org.nz/earthquake/story/2016p858000>.

Glossary of Real Estate Terms <www.realestate.co.nz>.

Hobsonville Point Constitution https://www.hprs.co.nz/wpcontent/uploads/2016/11/HPRS-Constitution-December-2016.pdf.

IAG New Zealand's website <www.need2know.org.nz>.

ICNZ "Canterbury Earthquakes” <www.icnz.org.nz>.

ICNZ "Cost of Natural Disasters" <www.icnz.org.nz>.

ICNZ "Kaikōura earthquake claims progressing well” (25 January 2018) 〈www.icnz.org.nz>. 
ICNZ "Protecting New Zealand from Natural Hazards" (October 2014) <www.icnz.org.nz>.

ICNZ "Replacement vs Indemnity insurance" <www.icnz.org.nz>.

ICNZ Consumer Guide for purchasers

<www.icnz.org.nz/fileadmin/Assets/PDFs/Publications/Consumer_guides/ICNZ_Consu

mer_Guide_-_Purchasing_home-insurance-in-a-multi-unit-building.pdf>.

ICNZ "Insurance Council welcomes measures to speed up Canterbury settlements" (online ed, 6 June 2018) <www.icnz.org.nz/media-resources/mediareleases/single/item/insurance-council-welcomes-measures-to-speed-up-canterburysettlements>.

ICNZ "Insurance industry isn't perfect, but general insurers are not unfair" (online ed, 24 June 2019) <www.icnz.org.nz/media-resources/media-releases/single/item/insuranceindustry-isnt-perfect-but-general-insurers-are-not-unfair>.

Immigration New Zealand <www.immigration.govt.nz>.

Incorporated Societies Register <www.is-register.companiesoffice.govt.nz>.

Insurance Council of Australia "Motor vehicle insurance" <www.insurancecouncil.com.au>.

Insurance Ombudsman "Complaints" <www.ifso.nz>.

Kenepuru Landing <www.kenepurulanding.co.nz>.

Harold Ledgerwood "The Scottish Tenement: Past, Present and Future" blog post on University of Aberdeen School of Law's website (online ed, 7 February 2020) <www.abdn.ac.uk>.

Lawyers Conveyancing "Conveyancing and Real Estate Encyclopaedia: Company Share Scheme" (online ed, Australia) <www.lawyersconveyancing.com.au>. 
MBIE: Tenancy Services website <www.tenancy.govt.nz>.

Money Hub "Retirement Villages (online ed, 23 December 2019) <www.moneyhub.co.nz/retirement-villages.html>.

Chris Moore and Michael Goodger "Maintenance issues and strata title legislation and proposals for reform” (online ed, 15 August 2008) <www.internationallawoffice.com/Newsletters/Real-Estate/New-Zealand/MeredithConnell/Maintenance-Issues-under-Strata-Title-Legislation-and-Proposals-for-Reform>.

National Insurance <www.gov.uk>.

New Zealand Dispute Resolution Centre's website <www.nzdrc.co.nz> (2021).

Brady Nixon "Market receptive intensification - A compact solution for Auckland and Housing Affordability" (Greater Auckland, April 2013) <www.greaterauckland.org.nz/wp-content/uploads/2013/06/Fee-Simple-IntensificationReport-Unitary-Plan-April-2013.pdf>.

Porirua City Council <www.poriruacity.govt.nz>.

Real Estate Authority "What do you need to know about cross lease ownership" (online ed, 1 November 2018) <www.settled.govt.nz>.

Royal Institution of Chartered Surveyors (RICS) Working Group on Maintenance of Tenement Scheme Property - Final Recommendations Report (Scotland, online ed, May 2019) <www.rics.org>.

Substance Abuse and Mental Health Services Administration "Phases of Disaster" <www.samhsa.gov>.

State Insurance website <www.state.co.nz/house-insurance/home-sum-insured>.

State Insurance website <www.secure.state.co.nz/home/Comprehensive\#/your_home>.

Simply Business <www.simplybusiess.co.uk>. 
Statista "Distribution of population in the United Kingdom (UK) as of 2018, by dwelling type" (online ed) <www.statista.com>.

Tenancy Services website <www.tenancy.govt.nz>.

TradeMe <www.trademe.co.nz>.

Tower Insurance Quotes <https://my.tower.co.nz/quote/house/page1>.

Village Guide "What is a licence to occupy?" (online ed, last accessed 25 April 2020) <www.villageguide.co.nz>.

"Voices from Scottish Tenements" https://vimeo.com/365520796.

Wellington City Council "Providing home for Wellingtonians" <www.wellington.govt.nz>.

Williams Corporation <www.williamscorporation.co.nz/completed-projects>.

Barry Zalma “Insured’s Obligation to Read the Insurance Policy” (online ed, January 2020) <www.irmi.com/articles/expert-commentary/insureds-obligation-to-read-the-insurancepolicy>.

7 Documents Released under the Official Information Act 1982

Acuo Ltd "Review of Kaikōura Earthquake Response Part 1" (September 2017) (obtained under Official Information Act 1982 request to the EQC).

Briefing to the Minister for Canterbury Earthquake Recovery "Shared Property: Reaching Agreement and Resolving Disputes" (5 June 2014) M13 - 14/622 (Obtained under Official Information Act 1982 request to the Department of Prime Minister and Cabinet). 
Memorandum of Understanding Relating to Kaikōura Earthquake Claims Management (obtained under Official Information Act 1982 request to the EQC.)

Official Information Act Response 20180116 "EQC Residential Building Cover Cap Limit" - Received 20 March 2018 - Published 7 June 2018 -Treasury <www.treasury.govt.nz/sites/default/files/2018-06/oia-20180116.pdf>.

Training materials for insurance companies (obtained under Official Information Act 1982 request to the EQC).

Treasury Report (T2015/1294) "Home Insurance - Implications of Sum Insured Cover” 23 June 2015, (obtained under Official Information Act 1982 request to Treasury).

\section{Conference Papers}

John Bridgeman "The Future City of Christchurch" (paper presented at New Zealand Insurance Law Association, Queenstown, 20 September 2018).

Robin Dafoe, CEO of the Condominium Authority of Ontario "Apartment/Condo Regulation, Management and Future Trends - International Perspective” (webinar, 15 December 2020).

Thomas Gibbons, "Emerging Trends in Case Law - The Big Picture" in Unit Titles Density and Intensity (NZLS seminar, 2015).

Thomas Gibbons and others "Easements and Covenants: Pushing the Boundaries" (NZLS seminar, 2008).

John Hogan "Unit Titles in the Tenancy Tribunal" in Unit Titles - Density and Intensity (NZLS seminar, 2015).

Lindsay Lloyd and Paul Michalik "Insurance Law - a practical guide" (NZLS seminar, 2012). 
Kerry O'Donnell "The nature of easements, covenants, consent notices and encumbrances" in Easements and Covenants - Pushing the Boundaries (NZLS seminar, 2008).

Susan O’Neill, Principal Policy Advisor, Ministry of Housing and Urban Development “Apartment/Condo Regulation, Management and Future Trends: New Zealand's Unit Titles Act" (webinar, 15 December 2020).

Joanna Pidgeon "Property - Converting Cross Leases to Freehold and Unit Titles" (NZLS webinar, 2020).

Michael Rehm "Double Crossed: The Discounting of Cross Lease Properties in Auckland" (paper presented to Pacific Rim Real Estate Society Conference, Lincoln, New Zealand, 19 January-22 January 2014).

\section{Insurance Policy Wordings}

\footnotetext{
AA Insurance Home insurance policy wording version AAI_HHOME_V2_1608 <www.aainsurance.co.nz/documents/policy-documents/home-insurance-policy.pdf>

FMG policy wording version 2484 07/16 VEL3302 <www.fmg.co.nz/globalassets/whatwe-cover/policy-wordings/policy-wording-2017-18/material-damage-policy-wording2017-18.pdf>;

Medical Assurance Society House Insurance policy wording version IDOM008 12/15. <www.mas.co.nz/assets/application-forms/General-Insurance/House-Insurance/Houseinsurance-policy-IDOM008-1215.pdf>.
}

State Home Comprehensive Insurance policy wording version SI1048/8 $\langle$ www.state.co.nz/PDFs/State_Home_Comprehensive_PW.pdf $>$. 
$\begin{array}{lllll}\text { State } & \text { Material } & \text { Damage } & \text { policy } & \text { SI4273/8 }\end{array}$

<www.state.co.nz/PDFs/State_Material_Damage_PW.pdf $>$.

Tower House Maxi Protection policy wording version P08 05-13 <www.tower.co.nz>

Tower Insurance website shows five available products: Premium House, Plus House,

Standard House, Landlord's Plus House, Sum Insured House Insurance <www.tower.co.nz>.

Vero Residential Home policy version VRHP09/15 <www.vero.co.nz/documents/personal-insurance/residential-home-policy-wordingoctober-2015.pdf>.

YPM wording www.ypm.co.nz/assets/2016-Insurance/YPM-agreed-wording-with-NZI2016-v2.pdf.

10 Parliamentary Documents

(14 July 1972) 379 NZPD 1089.

(2 July 2014) 700 NZPD 19128.

(26 May 2016) 714 NZPD 11335.

(29 March 2018) 728 NZPD 2774.

(29 March 2018) 728 NZPD 2775.

(29 March 2018) 728 NZPD 2780.

Cabinet Paper "Mixed-use Buildings Under the Earthquake Commission Act 1993" (10 March 2020) DEV-20-SUB-0039 <www.treasury.govt.nz/system/files/2020-12/mixeduse-buildings-eqc-dev-20-sub-0039.pdf>. 
Committee Clerk "Proposed Amendments to the Flat and Office Ownership Bill” L.D.O $62 / 3$.

LH McClelland, Registrar-General of Land to the Law Draftsman, 1 August 1969, document located in document titled "Homeowners and Householders Insurance Insurance under Unit Titles Act 1972", Archives New Zealand, archive reference AAXF W3614 23322 Box 63.

Flat and Office Ownership Bill (No 143-2) (explanatory note) located in " $36^{\text {th }}$ Parliament - Statutes Revision Committee - Bills - Public Bills - Unit Titles [Session 3]" located with Archive New Zealand, archive reference ABGX W3706 16127 Box 29.

Treasury - Cabinet Paper "Government Response to the Public Inquiry into the Earthquake Commission" (25 June 2020) DEV-20-SUB-0116 <www.treasury.govt.nz/publications/cabinet-paper/dev-20-sub-0116-governmentresponse-public-inquiry-earthquake-commission>.

Unit Title Amendment Bill (No 19-1) (explanatory note), document located in "Flat \& Office Ownership Bills - Unit Titles Act”, Archives New Zealand, archive reference ABWN W5021 6095 Box 399.

\section{Official Reports}

\section{New Zealand}

Kate Bryson and Natalie Allen Defining medium-density housing (BRANZ Study Report SR376, Judgeford, Porirua, September 2017).

Silvia Cartwright Public Inquiry into the Earthquake Commission (ISBN 978-0-94752025-0, 31 March 2020) <www.eqcinquiry.govt.nz>. 
Silvia Cartwright Public Inquiry into the Earthquake Commission: In the People's Voicea Snapshot of What the Inquiry Has Heard (online ed, December 2019) <www.eqcinquiry.govt.nz>.

Tim Denne and Alexia Beer Guarantees and Insurance Products: Market and Policy Analysis (MBIE, online ed, 1 October 2018) <www.mbie.govt.nz〉.

Department of the Prime Minister and Cabinet Greater Christchurch Group Whole of Government Report: Lessons from the Canterbury earthquake sequence" (online ed, 30 July 2017) <www.dpmc.govt.nz>.

Craig Fredrickson Arrested (Re)development? A Study of Cross Lease and Unit Titles in Auckland (Auckland Council technical report TR2017/025, 10 October 2017) $<$ knowledgeauckland.org.nz/publications/arrested-re-development-a-study-of-crosslease-and-unit-titles-in-auckland>.

EQC Annual Report 2010-2011<www.eqc.govt.nz>.

EQC Annual Report 2012-2013<www.eqc.govt.nz>.

EQC Annual Report 2018-2018 <www.eqc.govt.nz>.

EQC Resilience Strategy for Natural Hazard Risk Reduction 2019-2029 (online ed, November 2019) <www.eqc.govt.nz>.

Peter Gluckman The psychological consequences of the Canterbury earthquakes: A briefing paper (Office of the Prime Minister and Cabinet Advisory Services, online ed, 10 May 2011) <www.pmcsa.org.nz/wp-content/uploads/Christchurch-Earthquake-BriefingPsychosocial-Effects-10May11.pdf>.

Housing New Zealand Annual Report 2015/16. Law Commission Shared Ownership of Land (NZLC 59, 1999) <www.lawcom.govt.nz>. 
MBIE Building Performance - Consultation document (ISBN 978-1-99-001996-8, online ed, 6 April 2021) <www.mbie.govt.nz/dmsdocument/13808-consultation-documentbuilding-code-update-2021>.

MBIE Earthquake Repairs to Canterbury Homes - Home Inspection Survey Report (online ed, August 2015) <www.mbie.govt.nz/assets/9993cf73bd/home-inspection-surveyreport.pdf>.

MBIE Repairing and rebuilding houses affected by the Canterbury earthquakes (ISBN 978-0-478-39908-0, online ed, 1 December 2012) <www.building.govt.nz>.

MBIE Repairing and rebuilding residential multi-unit buildings: A guide for homeowners in Canterbury (ISBN: 978-0-478-43391-3, online ed, April 2015) <www.building.govt.nz>.

MBIE Review of the Unit Titles Act 2010 (online ed, December 2016) discussion document found on Glaister Ennor's website <www.glaister.co.nz>.

Ministry of Civil Defence \& Emergency Management Resilient New Zealand - A Aotearoa manahau: national civil defence emergency management strategy - 2003-2006 (Wellington, 2004). Cited in Eileen McSaveney and Simon Nathan, 'Natural hazards overview - Living dangerously' Te Ara - the Encyclopedia of New Zealand <www.TeAra.govt.nz/en/natural-hazards-overview>. Statistics New Zealand High density housing on the rise (online ed, 31 October 2019) <www.stats.govt.nz>.

Statistics New Zealand More than 10,000 townhouses, flats, and units consented in the last year (online ed, 30 September 2020) <www.stats.govt.nz>.

Treasury New Zealand's Future Natural Disaster Scheme: Proposed Changes to the Earthquake Commission Act 1993 (online ed, 5 July 2015) <www.treasury.govt.nz>.

Treasury Review of the Earthquake Commission Act (online ed, 12 February 2021) <www.treasury.govt.nz/news-and-events/reviews-consultation/review-earthquakecommission-act>. 
Treasury 'Sum Insured' Cover for Household Insurance - What Are the Risks? (online ed, 9 May 2016) <https://treasury.govt.nz/publications/research-and-commentary/rangitakiblog/sum-insured-cover-household-insurance-what-are-risks>.

Wellington City Council Mayor's Insurance Taskforce: Discussion Document (J009782, online ed, November 2019)

<www.buyingtherighthouse.co.nz/site_files/17612/upload_files/J009782-InsuranceTaskforce-Recommendations-Finance-Minister-Pages-Final.._.pdf?dl=1>.

\section{Scotland}

Law Commission (Scotland) Report on the Law of the Tenement (No 162, Scotland, 1998) <www.scotlawcom.gov.uk/files/4512/7989/7476/rep162.pdf>.

RICS Working Group on Maintenance of Tenement Scheme Property Final Recommendations Report (Scotland, online ed, May 2019) <www.rics.org>.

\section{United Kingdom}

Law Commission (United Kingdom) Commonhold Comparative Research (Working copy) (online ed, 10 December 2018) <www.s3-eu-west-2.amazonaws.com>.

\section{Empirical Research}

Focus Group discussion (Emma Gabor, Wellington, 14 September 2017).

"Information Sheet Pertaining to Fee Simple in Strata Titles" provided by email from Universal Homes (Property Developer) to Emma Gabor regarding strata fee simple property at West Hills, Auckland (7 April 2021). 
Interview with Chair of the ICNZ Personal Lines Committee (Emma Gabor, via Zoom Wellington/Auckland, 15 February 2021).

Interview with Crombie Lockwood, Insurance Broker (Emma Gabor, Christchurch, 13 October 2020).

Interview with DLA Piper, Law firm (Emma Gabor, Wellington, 20 November 2017).

Interview with EQC, Statutory Insurer (Emma Gabor, via Zoom Christchurch/Wellington, 2 July 2020).

Interview with Grant Shand Barristers and Solicitors, Insurance Lawyers (Emma Gabor, Christchurch, 28 November 2017).

Interview with Greenwood Roche, Law Firm (Emma Gabor, Wellington, 28 January 2020).

Interview with Homeowner 1 (Emma Gabor, via Zoom Christchurch/Wellington, 1 June 2020).

Interview with Homeowner 2 (Emma Gabor, via Zoom Christchurch/Wellington, 17 September 2020).

Interview with IAG New Zealand, Insurance Company (Emma Gabor, Wellington, 21 November 2017).

Interview with ICNZ, Insurance Council of New Zealand (Emma Gabor, Wellington, 15 November 2017).

Interview with Lane Neave, Law Firm (Emma Gabor, Wellington, 10 April 2018).

Interview with Nine Dots, Consultancy Company (Emma Gabor, Rotorua, 14 November 2017).

Interview with Residential Advisory Services, Government Department (Emma Gabor, Christchurch, 28 May 2019). 
Interview with Residential Risk Analysis Ltd, Consultancy Company (Emma Gabor, Wellington, 20 April 2018).

Interview with Roger Phillips, Ex-Board Member for Company Share Property (Emma Gabor, Wellington, 25 September 2018).

Interview with specialised contractor with Residential Advisory Services (Emma Gabor, Christchurch, 28 May 2019).

Interview with Storm McVay, Insurance Broker (Emma Gabor, Christchurch, 28 November 2017).

Interview with Vero Insurance New Zealand, Insurance Company (Emma Gabor, Auckland, 20 February 2018).

Interview with Young Hunter, Law Firm (Emma Gabor, Christchurch, 28 November 2017).

Online survey of EQC (Emma Gabor, Wellington, 22 January 2018).

Online survey of ICNZ (Emma Gabor, Wellington, 22 January 2018).

Online survey of insurance companies (Emma Gabor, Wellington, 22 January 2018).

Online survey of lawyers (Emma Gabor, Wellington, 22 January 2018).

Written interview questions (Q \& A style) to IAG New Zealand (Emma Gabor, Wellington, July 2019).

\section{Legal Articles and Other Research Papers}

Centre for Economics and Business Research Lloyd's Global Underinsurance Report (online ed, October 2012) 
<www.lloyds.com/ /media/Files/News\%20and\%20Insight/360\%20Risk\%20Insight/Glob al_Underinsurance_Report_311012.pdf>.

Deborah J DeWolfe Training Manual for Mental Health and Human Service Workers in Major Disasters (2nd ed, Education Resources Information Center, 2000) <www.hsdl.org>.

Thomas Gibbons "Strata/Units and Urban Development" (Law Talk Issue 927, April 2019).

Rabia Islam (Clapham Solicitors, Law Firm) "Law of Tenement, The Tenements (Scotland) Act 2004" (online ed, 24 July 2018) <www.davidclapham.co.uk>.

Richard Land and Janine Ballinger (Duncan Cotterill, Law Firm) "Property Update 'The legalities of the property landscape"” (online ed, 22 August 2013) <www.duncancotterill.com>.

Richard Lang and Janine Ballinger (Duncan Cotterill, Law Firm) "Web of insurance issues in cross lease properties" Mondaq (online ed, 10 May 2013) <www.mondaq.com>.

Law Link "Retirement village living: Pros and cons" (online ed, undated) <www.lawlink.co.nz/article/retirement-village-living-pros-cons/>.

Minter Ellison (Law Firm) "Government releases commercial rent relief package” (online ed, 10 June 2020) <www.minterellison.co.nz>.

Minter Ellison (Law Firm) "New land registration law coming" (online ed, 5 November 2018) <www.minterellison.co.nz>.

Timothy Orr "Inventor of Cross Lease Supports Legislation" Auckland District Law Society (online ed, 28 June 2013) <www.adls.org.nz>.

Robert Rennie "Last Piece of the Jigsaw: An outline of the Tenements (Scotland) Bill and how far it will innovate on the common law" (online ed, 1 March 2004) <www.lawscot.org.uk>. 
Lindsey Smith (Rainey Collins, Law Firm) "What is a Defective Cross Lease Title? Still Causing Problems...!” (online ed, 13 August 2018) <www.raineycollins.co.nz>.

Elizabeth Toomey and others Revised Legal Frameworks for Ownership and Use of Multi-dwelling Units (BRANZ Report ER23, 6 June 2017) <d39d3mj7qio96p.cloudfront.net/media/documents/ER23_Revised_legal_frameworks_fo r_ownership_and_use_of_multi-dwelling_units.pdf > .

Claire Tyler (Rainey Collins, Law Firm) "Company Share Apartments - What Are They and How Do They Work?” (9 November 2013) <www.raineycollins.co.nz>.

\section{Submissions}

ADLS "Submission to the Finance and Expenditure Committee on the Unit Titles (Strengthening Body Corporate Governance and Other Matters) Amendment Bill 2021" (25 June 2021).

Jeff Andrew (secretary to three company share schemes) "Personal submission to the Statutes and Revisions Committee on the Flat and Office Ownership Bill 1972" (17 February 1972) in folder document titled " $36^{\text {th }}$ Parliament - Statutes Revision Committee - Bills - Public Bills - Unit Titles [Session 3]” located with Archives New Zealand, archive reference ABGX W3706 16127 Box 29.

Commercial Union Assurance "Submission to the Department of Justice on the Unit Titles Act 1972" (30 May 1977) - document located in "Houseowners and Householders Insurance - Insurance under Unit Titles Act 1972" file, Archives New Zealand, Archives ref AAXF W3614 23322 Box 63, record number 11/1/11.

Department of Justice "Comments on the Flat and Office Ownership Bill" (undated) located in Archives New Zealand file titled " $36^{\text {th }}$ Parliament - Statutes Revision Committee - Bills - Public Bills - Unit Titles [Session 3]”, Archive ref ABGX W3706 16127 Box 29. 
Gateway Flats Limited "Submission to the Statutes and Revisions Committee on the Flat and Office Ownership Bill 1972 (20 March 1972) in folder document titled " $36^{\text {th }}$ Parliament - Statutes Revision Committee - Bills - Public Bills - Unit Titles [Session 3]" located with Archives New Zealand, archive reference ABGX W3706 16127 Box 29. Gateway Flats Limited "Submission to the Statutes and Revisions Committee on the Flat and Office Ownership Bill 1972 (5 April 1972) in folder document titled " $36^{\text {th }}$ Parliament - Statutes Revision Committee - Bills - Public Bills - Unit Titles [Session 3]" located with Archives New Zealand, archive reference ABGX W3706 16127 Box 29.

IAG New Zealand "Submission to the Ministry of Business, Innovation and Employment on the Insurance Contract Law Review" (13 July 2018) <www.mbie.govt.nz>.

IAG New Zealand "Supplementary Submission to the Finance and Expenditure Committee on the Unit Titles (Strengthening Body Corporate Governance and Other Matters) Amendment Bill $2021 \quad$ (25 June 2021). <www.parliament.nz/resource/enNZ/53SCFE_EVI_99361_FE1681/5f43581c5c3d04640 $4 \mathrm{ff} 4476045 \mathrm{c} 85 \mathrm{~d} 03 \mathrm{~d} 5 \mathrm{a} 0 \mathrm{cfe}>$.

ICNZ "Submission on the Unit Titles (Strengthening Body Corporate Governance and Other Matters) Amendment Bill 2021 (29 April 2021) <www.parliament.nz/resource/enNZ/53SCFE_EVI_99361_FE1389/c9f83bc320ea296266a4c1005a9e96ac44a20b68>.

William Lavelle (architect) "Submission to the Statutes Revision Committee on the Office and Flat Ownership Bill 1972” (15 February 1972) located in Archives New Zealand file titled " $36^{\text {th }}$ Parliament - Statutes Revision Committee - Bills - Public Bills Unit Titles [Session 3]”, Archive ref ABGX W3706 16127 Box 29.

NZLS “Submission on Unit Titles (Strengthening Body Corporate Governance and Other Matters) Bill 2021 (3 May 2021) <www.lawsociety.co.nz>.

State Insurance Office "Submission to the General Manager in relation to the Head Office Circular 1975/49 on the Insurance under the Unit Titles Act" (22 December 1975) - located in "Houseowners and Householders Insurance - Insurance under Unit Titles Act 1972" 
file, Archives New Zealand, Archives ref AAXF W3614 23322 Box 63, record number $11 / 1 / 11$. 